\title{
Phytoseiid mites (Acari: Gamasina) in Finnish apple plantations with reference to integrated control of phytophagous mites
}

\author{
TUOMO TUOVINEN \\ Agricultural Research Centre of Finland \\ Institute of Plant Protection \\ FIN-31600 Jokioinen, Finland
}

Academic dissertation

To be presented, with the permission of the Faculty of Agriculture and Forestry of the University of Helsinki, for public criticism in Auditorium XII on May 26th, 1993, at 12 o'clock noon. 


\section{PREFACE}

This study was carried out at the Agricultural Research Centre of Finland, Institute of Plant Protection in Jokioinen, during 1981-1992. I am most grateful to Professor Martti Markkula for his encouragement in the beginning of my research work and for precious criticism and comments on part of the manuscripts of the original articles. I also want to express my thanks to Professor Unto Tulisalo, my teacher in agricultural entomology, for his support in my first steps in entomological research. I am deeply grateful to Professor Anna-Liisa Varis for her valuable comments and guidance during this work and for her constructive criticism on the manuscript of this thesis.

My sincere thanks are due to all my colleagues at the Institute of Plant Protection. I want to thank Dr. Sirpa Kurppa, Professor Heikki Hokkanen, Dr. Kari Tiilikkala and Mr. Seppo Korpela, for their critical and helpful comments on manuscripts of the original articles. Their and my other colleagues' support was important also in my decision to start the postgraduate studies and to work on this thesis.

Special thanks are due to Professor Danuta Kropczynska, University of Warsaw, whose visit at the Agricultural Research Centre in 1985 actually was the beginning of the work that led into this thesis. Her helpful advice and warm encouragement during this research has been of great value to me.

I express my sincere gratitude to my co-author of an original article, Mr. Joost Rokx, for taking part in my studies in 1989. The assistant technicians, especially Ms. Tarja Kallio, Ms. Satu Smolander and Ms. Arja Hämäläinen, have done valuable work in sampling, counting and preparing mites. I want to express my warm gratitude to them.

Last but certainly not least, I want to thank my wife Tiina and my family whose support and encouragement have helped me complete this work. 


\section{LIST OF ORIGINAL ARTICLES}

The original articles summarized here are:

I TUOVInEN, T. 1993. Identification keys and notes on the occurrence of phytoseiid mites (Gamasina: Phytoseiidae) in Finnish apple plantations and their surroundings. Entomologica Fennica (in press).

II TuOvinen, T. \& RoKX, J.A.H. 1991. Phytoseiid mites (Acari: Phytoseiidae) on apple trees and in surrounding vegetation in southern Finland. Densities and species composition. Experimental \& Applied Acarology 12: 35-46.

III TUOVINEN, T. 1993. Influence of surrounding trees and bushes on the phytoseiid mite fauna on apple orchard trees in Finland. Agriculture, Ecosystems \& Environment (in press)

IV TuOvinen, T. 1989. Chemical control of European red spider mite Panonychus ulmi (Koch). I. Evaluation of flubenzimine. Annales Agriculturae Fenniae 28: 317-332.

V TuOvinen, T. 1990. Chemical control of European red spider mite Panonychus ulmi (Koch). II. Evaluation of clofentezine and hexythiazox. Annales Agriculturae Fenniae 29: 195-204.

VI TUOVINEN, T. 1990. Effect of four fungicides on phytophagous and predatory mites on apple trees. Annales Agriculturae Fenniae 29: 205-215.

In the following text, these articles are referred to by the above Roman numerals. 


\section{CONTENTS}

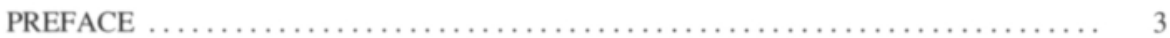

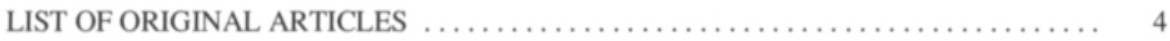

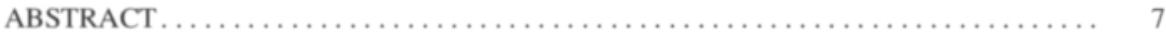

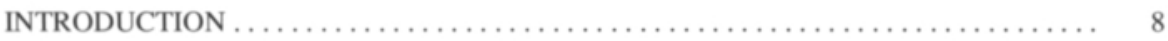

1 Importance of phytoseiid mites on apple $\ldots \ldots \ldots \ldots \ldots \ldots \ldots \ldots \ldots \ldots \ldots \ldots \ldots \ldots \ldots$

2 Pest status of phytophagous mites on apple $\ldots \ldots \ldots \ldots \ldots \ldots \ldots \ldots \ldots \ldots \ldots \ldots \ldots$

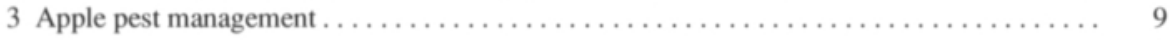

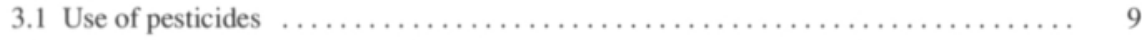

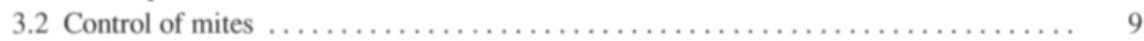

3.3 Current and future concepts of pest management $\ldots \ldots \ldots \ldots \ldots \ldots \ldots \ldots \ldots \ldots$

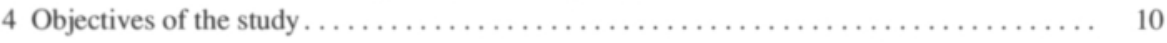

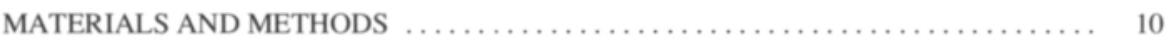

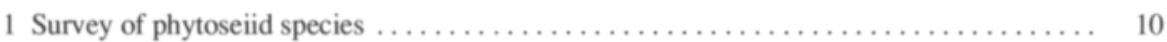

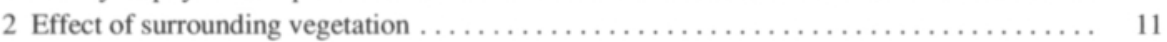

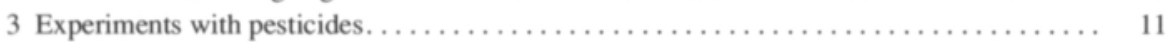

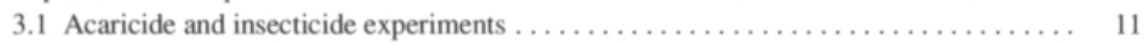

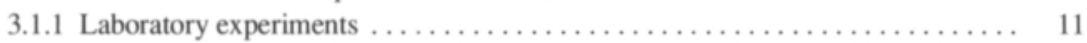

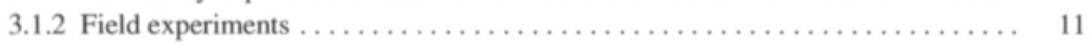

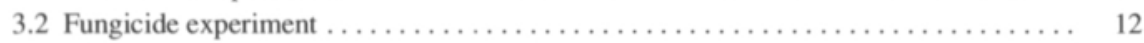

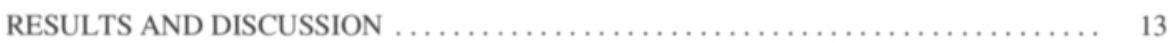

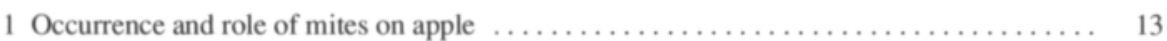

1.1 Mite populations on sprayed and unsprayed trees $\ldots \ldots \ldots \ldots \ldots \ldots \ldots \ldots \ldots \ldots$

1.2 Phytoseiid species and their relevance in integrated control $\ldots \ldots \ldots \ldots \ldots \ldots \ldots$

1.3 The role of phytoseiid mites on apple trees $\ldots \ldots \ldots \ldots \ldots \ldots \ldots \ldots \ldots \ldots \ldots$

2 Surrounding vegetation as a source of phytoseiid mites $\ldots \ldots \ldots \ldots \ldots \ldots \ldots \ldots \ldots \ldots$

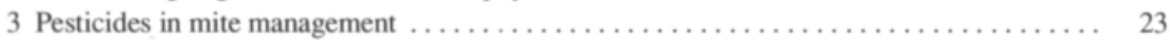

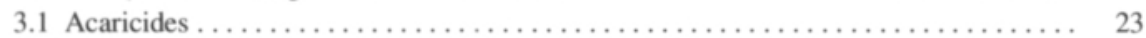

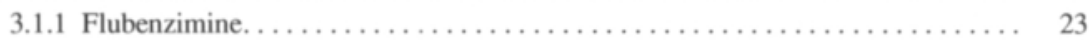

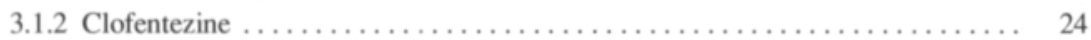

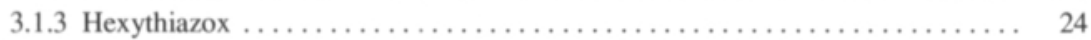

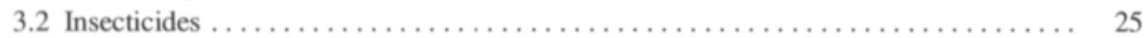

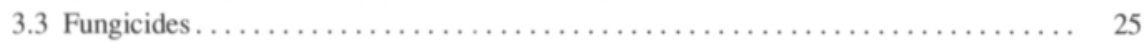

3.3 .1 Bitertanol. . . . . . . . . . . . . . . . . . . . . . . . . . . . . . .

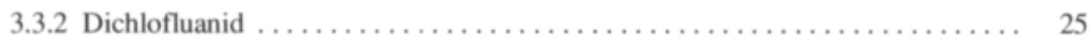

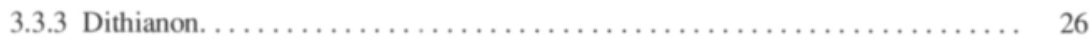

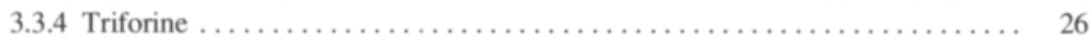

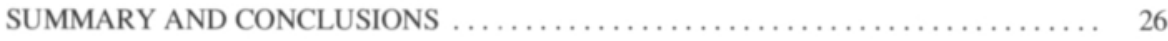

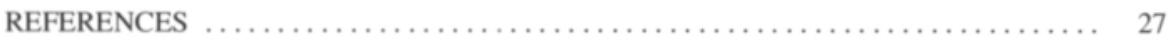

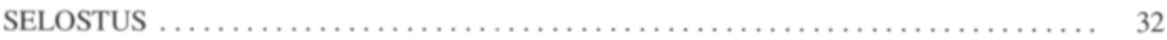




\title{
Phytoseiid mites (Acari: Gamasina) in Finnish apple plantations with reference to integrated control of phytophagous mites
}

\author{
TUOMO TUOVINEN
}

Tuovinen, T. 1993. Phytoseiid mites (Acari: Gamasina) in Finnish apple plantations with reference to integrated control of phytophagous mites. Agric. Sci. Finl. 2: Supplement No. 1. 33 p. (Agric. Res. Centre of Finland, Inst. Pl. Protect., FIN-31600 Jokioinen, Finland.)

On apple tree leaves, the most abundant predatory phytoseiid species were Euseius finlandicus (Oudemans), comprising 39\% of specimens found in surveys in 1985 and 1989, Phytoseius macropilis (Banks), 32\%, and Paraseiulus soleiger (Ribaga), $18 \%$. Amblyseius subsolidus (Beglyarov) and A. reductus Wainstein occurred occasionally in relatively high densities, whereas Anthoseius rhenanus (Oudemans), A. suecicus (Sellnick), A. richteri (Karg), A. bakeri (Garman), A. viktorovi Wainstein, Paraseiulus talbii (Athias-Henriot) and P. triporus (Chant \& Yoshida-Shaul) occurred rarely and always in low densities. On unsprayed trees, the mean density of phytoseiid mites was 1.2 mites/leaf. On sprayed trees, none or only a few phytoseiids were found, but the density of the European red spider mite Panonychus ulmi (Koch) was much higher than on unsprayed trees. Indigenous phytoseiid mites appeared to be capable of maintaining the $P$. ulmi population level under the economic threshold on unsprayed apple trees. The presence of the common prey mites, $P$. ulmi, the rust mite Aculus schlechtendali (Nalepa), or tydeid mites was not necessary for the presence of phytoseiid mites. Relatively high numbers of E. finlandicus, $P$. macropilis and $P$. soleiger were found, although prey mites were scarce.

Many deciduous trees and bushes support high populations of phytoseiid mites. The highest numbers were found on Aesculus hippocastani, Corylus avellana, Fraxinus excelsior, Ribes nigrum, Rubus odoratus, Sorbus aucuparia, Tilia spp. and Ulmus glabra. E. finlandicus occurred most commonly and in the highest densities, followed by $P$. macropilis, $P$. soleiger, $P$. triporus and $A$. rhenanus. E. finlandicus can immigrate rapidly from adjacent vegetation into an orchard after harmful spraying if suitable plants are present, and tall trees appeared to be more important than low bushes as natural sources of phytoseiids for aerial dispersal.

In acaricide tests, flubenzimine was effective against $P$. ulmi, but it was harmful to $E$. finlandicus and $P$. macropilis. A single treatment with clofentezine and hexythiazox, although effective against $P$. ulmi, was harmless to $E$. finlandicus and $P$. macropilis, but repeated sprays of both acaricides significantly reduced the density of phytoseiids.

The fungicides dithianon and bitertanol were harmless to phytoseiids, but dichlofluanid was harmful. Triforine sprays also reduced the numbers of phytoseiid mites, but the effect was only temporary. It had a $75 \%$ effect on $P$. ulmi winter eggs when sprayed just before hatching. Dichlofluanid was effective against $P$. ulmi and $A$. schlechtendali.

Key words: Phytoseiidae, Panonychus ulmi, Aculus schlechtendali, apple, integrated control, natural control, chemical control, side effects of pesticides 


\section{INTRODUCTION}

Over 1600 species are known in the family Phytoseiidae (Acari: Gamasina) (CHANT and YosHIDASHAUl 1991). Phytoseiid mites are predators of spider mites (Tetranychidae), eriophyid gall mites (Eriophyidae), tarsonemid mites (Tarsonemidae) and tydeid mites (Tydeidae). A few species are also reported to consume insects, e.g. thrips (OVERMEER 1985).

\section{Importance of phytoseiid mites on apple}

Numerous studies have demonstrated that phytoseiid mites can effectively regulate spider mite populations on fruit trees (DOSSE 1960, COLLYER 1964, Wildbolz and Staub 1986). RabBinge (1976) showed in a comprehensive simulation study on the effect of a phytoseiid mite Amblyseius andersoni (Chant) [A. potentillae (Garman)] on the European red spider mite Panonychus ulmi (Koch) in an apple tree environment that a wide range of prey-predator ratios is functional. The direct use of phytoseiids to control spider mites in orchards is also well documented (CROFT and BARNES 1971, McMurTRY and van de VRIE 1973, HOY 1982, IORIATTI et al. 1983, SEIER 1989, TRAPMAN 1989). In many cases, the introduced phytoseiid mites have been conserved by using selective pesticides, to which they are resistant (OVERMEER and van ZON 1983, SOLOMON and EASTERBROOK 1983, SOLOMON and FITZGERALD 1984, GENINI and BAILloD 1987, MinKs et al. 1988, SolOMON 1988).

In Europe, Typhlodromus pyri Scheuten and A. andersoni are the two most commonly used phytoseiid species in integrated pest management (IPM) programmes. These species occur commonly and have strains resistant to organophosphorous insecticides (OPs) (HOYT 1972, CRANHAM et al. 1983, OVERMEER and van ZON 1983, HADAM et al. 1986, GENINI and BAILLOD 1987). T. pyri is able to maintain spider mite populations under economic thresholds in commercial orchards (WILDBOLZ and Staub 1986, Genini and Baillod 1987). Some other phytoseiid species have also been considered to be important in European conditions, e.g. Euseius finlandicus (Oudemans) (SECHSER et al. 1984).

Considerable numbers of phytoseiid species have been identified in recent surveys on apple and many other plants in Denmark and Norway (EDLAND 1986, HANSEN and JOHNSEN 1986, EDLAND 1987, KARG and EdLAND 1987). In Sweden, SELLNICK (1958) reported of eight species on cereals and grasses. In Finland, phytoseiid mites have not previously been surveyed, but reports concerning a part of the present data have been published (KROPCZYNSKA and TUOVINEN 1987, 1988). LiSTO et al. (1939) mentioned predatory mites as natural enemies of $P$. ulmi, but data on the species in question were not presented. KANERVo (1961) listed important natural enemies of $P$. ulmi found to occur on apple in Finland, and included 'Typhlodromus sp.' as one of the high priority species. Listo et al. (1939) even presented the results of feeding studies on an unidentified phytoseiid species and concluded that the species was an efficient predator of P. ulmi,

\section{Pest status of phytophagous mites on apple}

In northern Europe, $P$. ulmi is the most important tetranychid species on apple (van de VRIE 1985). It is most common in orchards where intensive cultivation methods have been applied (LiSTO et al. 1939, POST 1962, CRANHAM 1979). One reason for the higher densities in well-kept orchards than in home gardens is the better nutritional conditions for spider mites: owing to pruning and fertilization, the quality of leaves as a food source for P. ulmi is better than in abandoned trees (POST 1962). However, it is the harmful effect of wide-spectrum insecticides on the natural enemies of $P$. ulmi that is considered to be the most important reason for the injuriousness of P. ulmi (McMURTRY et al. 1970, van de VRIE 1972, CROFT and BROWN 1975). Numerous cases of resistance to pesticides in $P$. ulmi show that mite problems are not easy to control by 
chemical means alone (HELLE and van de VRIE 1974, Cranham 1982, Cranham and Helle 1985, PreE and WAGNER 1987, DenNEHY et al. 1988),

P. ulmi is the only serious mite pest in commercial apple orchards in Finland (LISTO et al. 1939, KANERVO 1960, VAPPULA 1965), and its pest status has persisted despite the introduction of specific acaricides (TUOVINEN 1992a). The other common spider mite species in this country, the two-spotted spider mite Tetranychus urticae (Koch), occurs only occasionally on apple trees. An eriophyid mite, the apple rust mite Aculus schlechtendali (Nalepa), is not rated as a serious pest on apple in Finland, although it is capable of damaging apple trees (VAPpula 1965). In Sweden, though, this mite has lately caused considerable damage (TORNEUS 1990), and recent observations have shown that it has become more common in Finland, too (Tuovinen, unpubl.). Other eriophyid mites found on apple, Phyllocoptes malinus (Nalepa), which occurs on old, neglected trees, and Phyllocoptes mali (Nalepa), which is very rare, are not rated as pests (VAPPULA 1965).

Listo et al. (1939) and KANERVo (1961, 1967) studied the natural enemies of $P$. ulmi in Finland, focusing on insect predators and their conservation. After their studies, the biological control of $P$. ulmi was largely ignored in practice, and growers were advised to use acaricides to combat the increasing mite populations. The problems that arose in the 1960 s were partly due to the resistance of $P$. ulmi to OP insecticides. When used in the 1950 s, they had been effective against $P$. ulmi (HEIKINHEIMO 1956), but later less so (MARKKULA and KURPPA 1985). The destructive effect of OPs on natural insect enemies of $P$. ulmi was documented quite soon (KANERVO 1961).

\section{Apple pest management}

\subsection{Use of pesticides}

In 1984-1989, the average number of sprays in commercial apple orchards included 2.1-3.7 insecticide, 1.1-1.7 acaricide and 5.3-7.3 fungicide sprays
(TUOVINEN 1992a). Most of the insecticides were OPs although some pyrethroids were also used. The main acaricide was chinomethionate plus several minor products, and the main fungicides were dithianon and bitertanol plus a few minor products. The common target insects in Finnish apple orchards are the apple fruit moth Argyresthia conjugella Zell., tortricids e.g. Hedya nubiferana (Hw.), the codling moth Cydia pomonella (L.), the winter moth Operophtera brumata L., the aphids Aphis pomi L. and Dysaphis spp., and several heteropterous bug species (Lygus spp., Plesiocoris rugicollis Fall.). Acaricides were used almost exclusively to control $P$. ulmi, and fungicides to control the apple scab Venturia inaequalis (Cooke) Winter.

\subsection{Control of mites}

In Finland, $P$. ulmi has been controlled by chinomethionate and dicofol, which are usually applied at the time of flowering in May-June, or by oxydemetonmethyl. Only a few growers apply mineral oil sprays against winter eggs in spring. Registration of dicofol is no longer valid (BLOMQVIST et al. 1992). In warm and dry seasons, when $P$. ulmi densities tend to grow too high, extra sprays have been applied later in the season. Despite the average or higher number of sprays, $P$. ulmi numbers are still too high in some orchards (TUOVINEN 1992a). Resistance to chinomethionate and dicofol has been reported in P. ulmi populations in Europe and North America (CRANHAm and Helle 1985, Riedl et al. 1992). Resistance to acaricides in Finnish P. ulmi strains has not been studied in the laboratory, but control failures indicate that resistance occurs in some orchards (Tuovinen, unpubl.).

A. schlechtendali has not been a serious pest in Finland, but lately some damage caused by it has been recorded. It has been controlled mainly by chinomethionate or insecticides sprayed against other pests.

\subsection{Current and future concepts of pest management}

Integrated pest management, IPM, has been a lead- 
ing concept for pest control research in many countries since the 1950s (WEARING 1982). In Finland, LISTO et al. (1939) already oriented towards IPM. The first successes with IPM in fruit orchards were obtained in Canada (PICKETT et al. 1958), since then IPM methods have been successfully applied and become accepted practice in the USA (CROFT 1975), Europe (GRUYS 1975, WILDBOLZ 1979) and New Zealand (WEARING et al. 1978). One of the benefits of IPM methods is that mite pests are generally controlled by introduced or naturally occurring, conserved predators. The availability of these predators is assured by using selective pesticides which do not harm natural enemies, e.g. phytoseiid mites (WEARING et al. 1978).

Later, the term 'Integrated Fruit Production' (IFP) was introduced to expand the principles of IPM to cover the whole growing system, including all growing techniques that may affect plants, pests and natural enemies. In the joint statement of the IOBC (International Organization for Biological and Integrated Control of Noxious Animals and Plants) working group 'Integrated plant protection in orchards' and the ISHS (International Society for Horticultural Science) working group 'Integrated fruit production', in 'General principles, guidelines and standards for integrated production of pome fruits in Europe, and procedures for endorsement of national or regional guidelines and standards', they state under the heading 'Integrated plant protection' that, "Populations of key natural enemies (eg., Phytoseiid mites on apple or Anthocorid predators on pear) must be preserved. This means plant protection products toxic to them may not be used. Where Phytoseiid predators are absent from apple orchards, they should be introduced where neces- sary." (DICKLER and SCHÄFERMEYER 1991).

However, before the above principles can be followed, it is necessary to know the local status of phytoseiid populations.

\section{Objectives of the study}

The study covers six main areas:

1) keys to and descriptions of the phytoseiid mites found in Finland (I);

2) the occurrence and species composition of phytoseiid mites on sprayed and unsprayed apple trees (I, II, III);

3) the occurrence of phytoseiid mites on deciduous trees and bushes (II);

4) the effect of surrounding vegetation on the occurrence of phytoseiid mites in apple orchards (III);

5) the effect of acaricides on phytophagous and predatory mites (IV, V); and

6) the side effects of fungicides on the mites inhabiting apple leaves (VI).

The main purpose of the study is to provide basic information on naturally occurring species of Phytoseiidae. As the taxonomy of the family Phytoseiidae is not well known, keys to and short descriptions of the species occurring in Finland are also given. The value and characteristics of phytoseiid mites as natural enemies of $P$. ulmi and $A$. schlechtendali in Finnish apple orchards are evaluated in the light of results and a literature search from other countries. Information is also given about the application of mite management methods as well as effective use of acaricides.

\section{MATERIALS AND METHODS}

\section{Survey of phytoseiid species}

Apple leaf samples $(\mathrm{N}=146)$ were collected in southern Finland from sprayed apple trees in commercial orchards and from unsprayed trees in home gardens, mainly in August and September, in 1985 and 1989 (I). In 1989, samples $(\mathrm{N}=54)$ from other deciduous trees and bushes around orchards were also inspected (II). Phytoseiid mites were prepared and identified, and other mites were either counted or estimated (1985) or only eriophyid and tetranychid mites were estimated (1989).

During the study period, some 4400 phytoseiid mite specimens on apple trees, and 5000 specimens 
on other plants were prepared and identified. These specimens served as reference materials for the keys to and notes on host plants of the species of the family Phytoseiidae in Finland. The generic classification used herein follows mainly that of KARG (1983) (I).

\section{Effect of surrounding vegetation}

The study comprised 14 normally sprayed commercial apple orchards in 1989 (selected orchards surveyed in II) and one sprayed orchard surveyed in 1991 (III). Leaf samples were collected from sprayed and unsprayed apple trees if available nearby, and from the main species of deciduous trees and bushes in the vicinity. The phytoseiid species composition on sprayed and unsprayed apple and on the main vegetation in the vicinity was analysed and compared in each orchard. In 1991, the vegetation around and within a 2-ha orchard was surveyed, and the compositions of phytoseiid species and their numbers were compared with those in the nearest surrounding vegetation.

\section{Experiments with pesticides}

\subsection{Acaricide and insecticide experiments}

The effect of clofentezine (Apollo, Schering), flubenzimine (Cropotex, Bayer) and hexythiazox (Nissorun, Nippon Soda) on P. ulmi and other mites inhabiting apple trees was studied in field and laboratory experiments (IV, V). Observations of the effect of the following other acaricides and insecticides are included: chinomethionate (Morestan, Bayer), deltamethrin (Decis 25 EC, Hoechst), dicofol (Kelthane, Rohm and Haas), diflubenzuron (Dimilin, Duphar B.V.), fenbutatinoxide (Torque, Shell), mineral oil (Ovipron, BP) and oxydemetonmethyl (Metasystox, Bayer). The pesticides tested in the field experiments are summarized in Table 1.

\subsubsection{Laboratory experiments}

The effect of ovicidal acaricides on $P$. ulmi winter eggs was evaluated in the laboratory with the help of a Potter tower. Tests with clofentezine and hexythiazox were carried out using eggs at different stages of development (V). The evaluation technique was largely as follows:

1) winter eggs from one orchard were used per test;

2) small, halved pieces of twig, each containing 20-50 eggs, were placed on Petri dishes and sprayed with $2 \mathrm{ml}$ liquid per spray;

3) at least four replicates, with at least 100 eggs/replicate, were sprayed;

4) control dishes were sprayed with pure water;

5) the pieces of twig were circled with insect glue to catch all hatched larvae;

6) Petri dishes containing the pieces of twig were preserved in a growing chamber at $+20 /+15{ }^{\circ} \mathrm{C}$, $75 \pm 10 \% \mathrm{Rh}$ and $13 / 11 \mathrm{~h} \mathrm{L/D} \mathrm{photoperiod;}$

7) 2 and 4 weeks later the hatched larvae inside the circle of glue were counted.

\subsubsection{Field experiments}

Field experiments were carried out in 1981-1989 in experimental orchards using a randomized block design with 3-4 replicates of single or 2-6 trees, or in commercial orchards in 0.5-1 ha blocks (IV, V). In the experimental orchards, sprays were applied with a handgun sprayer, and in commercial orchards with a tractor mistsprayer; $300-4001 /$ ha water was used.

The effect of acaricide treatments was assessed several times during the summer and, in most cases, winter eggs were inspected later in the autumn. Usually, the number of mites was also counted before the sprays. Some of the experiments were designed to enable the effect of spraying to be monitored during the following season (IV). To assess the effect of sprays, leaves were inspected under a stereomicroscope, and mobile stages and eggs of $P$. ulmi were counted. The other mite groups, phytoseiid mites and tydeid mites (Acari: Tydeidae) were counted when appropriate, and numbers of eriophyid mites were estimated. In two experiments, the occurrence of predators other than phytoseiids was evaluated from beating samples (V). 
Table 1. Summary of the pesticides tested in field experiments (IV,V,VI)

\begin{tabular}{|c|c|c|c|}
\hline Active ingredient & Product & A.i. g/1001 & References \\
\hline Bitertanol & Baykor & 50 & $\begin{array}{l}\text { VI Figs. 2-6; } \\
\text { Table } 2\end{array}$ \\
\hline \multirow[t]{4}{*}{ Chinomethionate } & Morestan & 37.5 & IV Figs. 3a,b \\
\hline & & 55 & IV Table 7 \\
\hline & & 62.5 & IV Figs. 3a,b \\
\hline & & & V Tables 3,5,6 \\
\hline \multirow[t]{4}{*}{ Clofentezine } & Apollo & 25 & V Table 7 \\
\hline & & 50 & V Table 9 \\
\hline & & 85 & V Table 7 \\
\hline & & 100 & V Tables 3,4 \\
\hline \multirow[t]{2}{*}{ Deltamethrin } & Decis 25EC & 2.5 & IV Table 4 \\
\hline & & 6.25 & IV Table 5 \\
\hline Dichlofluanid & Euparen & 400 & $\begin{array}{l}\text { VI Figs. 2-6; } \\
\text { Table } 2\end{array}$ \\
\hline Dicofol & Kelthane W & 139 & IV Table 5 \\
\hline Diflubenzuron & Dimilin & 125 & IV Tables 3,5 \\
\hline Dithianon & Delan & 180 & $\begin{array}{c}\text { VI Figs. 2-6; } \\
\text { Table } 2\end{array}$ \\
\hline Fenbutatinoxide & Torque & 250 & IV Tables 4,5 \\
\hline \multirow[t]{6}{*}{ Flubenzimine } & Cropotex & 25 & IV Table 8 \\
\hline & & 85 & IV Table 8 \\
\hline & & 150 & $\begin{array}{r}\text { IV Figs. 3a,b; } \\
\text { Tables } 3,7\end{array}$ \\
\hline & & 200 & IV Figs. 3a,b \\
\hline & & 250 & IV Figs. 3a,b; \\
\hline & & & $\begin{array}{l}\text { Tables 4,5,6 } \\
\text { V Table 4 }\end{array}$ \\
\hline Flucythrinate & Cybolt & 10 & IV Table 5 \\
\hline \multirow[t]{5}{*}{ Hexythiazox } & Nissorun & 5 & V Table 7 \\
\hline & & 10 & V Table 9 \\
\hline & & 12.5 & V Table 5 \\
\hline & & 15 & V Tables 6,8 \\
\hline & & 17 & V Table 7 \\
\hline Mineral oil & Ovipron & 2910 & V Table 9 \\
\hline Oxydemeton-methyl & Metasystox R & 132.5 & IV Figs. 3a,b \\
\hline Triforine & Saprol & 96 & $\begin{array}{l}\text { VI Figs. 2-6; } \\
\text { Table 2 }\end{array}$ \\
\hline
\end{tabular}

\subsection{Fungicide experiment}

The following fungicides are permitted for use against apple scab in Finland: bitertanol (Baykor, Bayer), copperoxychlorid (Kuprijauhe, Hoechst, and OB 21, Bayer), dichlofluanid (Euparen, Bayer), dithianon (Delan, Shell Agrar) and triforine (Saprol, Shell Agrar). Copperoxychlorid is not recommended for commercial orchards, and so was not tested (Table 1) (VI).
The effect of fungicide sprays on $P$. ulmi winter eggs bef ore they hatched was studied in the laboratory with a method similar to that used for ovicidal acaricides (see 3.1.1).

The effect of direct sprays on young P.ulmi larvae was studied using a Potter tower. Single leaves with 25 larvae each were sprayed. The test units were then kept in a growing chamber, and the development of larvae to nymphal and adult stages was monitored for 11-16 days. 
A field experiment was conducted in an abandoned orchard in 1989 to test the effect of fungicide sprays on $P$. ulmi and other mite species occurring in the orchard. The trees were sprayed four times in June-July. Samples of 50 leaves were collected twice after the sprays and later in September. Eggs and mobile stages of $P$. ulmi, mobile stages of phytoseiid and tydeid mites were counted, and the numbers of eriophyids were estimated. The composition of phytoseiid species was investigated.

\section{RESULTS AND DISCUSSION}

\section{Occurrence and role of mites on apple}

\subsection{Mite populations on sprayed and unsprayed trees}

The survey conducted in 1985 , reported by KROPCZYNSKA and TUOVINEN (1988), and the survey made in 1989 (II) show that phytoseiid mites occur more abundantly and frequently on unsprayed than on sprayed trees (Figures. 1 and 2). For the statistical analysis, 19 inappropriate samples were excluded from the original data of KROPCZYNSKA and TUOVINEN (1988) in order to make the material geographically more compatible between years. The number (mean $\pm \mathrm{SE}$ ) of phytoseiid mites/leaf on unsprayed trees, $1.62 \pm 0.26$ and $1.15 \pm 0.19$, was significantly greater than on sprayed trees, $0.034 \pm 0.023$ and $0.054 \pm 0.022$, in 1985 and 1989, respectively (Kruskal-Wallis Oneway ANOVA, $\mathrm{Chi}^{2}=55.35, \quad \mathrm{~N}_{85}=79, \mathrm{P}<0.001$; $\left.\mathrm{Chi}^{2}=27.65, \quad \mathrm{~N} 89=48, \quad \mathrm{P}<0.001\right) . \quad$ The sprayed samples were from commercial, well-kept orchards, and as a rule sprayings included several fungicide (4-11), acaricide (0-3) and insecticide (0-4) treatments (II). Most of the unsprayed samples were from abandoned trees in home gardens. In 1989 , phytoseiid mites were found in over $60 \%$ of sprayed orchards but in 1985 in only $24 \%$ (Fig. 2). The difference is thought to result from the difference in inspection procedures, as the washing method used in 1989 allows very low numbers of mites to be detected more readily than the visual inspection practised in 1985 .

The presence of phytoseiid mites in abandoned or unsprayed apple trees and their low density on sprayed trees were consistent with the findings of

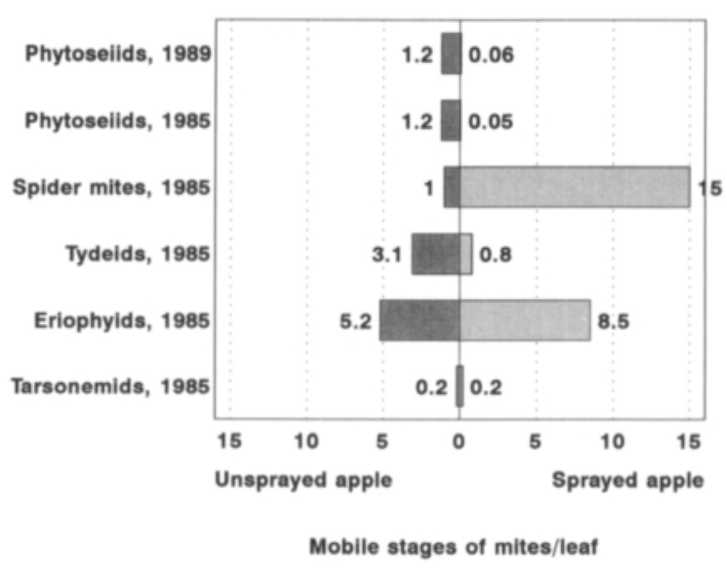

Fig. 1. Abundance of mites in apple leaf samples in 1985 and 1989. (KROPCZYNSKA and TUOVINEN 1988, I, II).

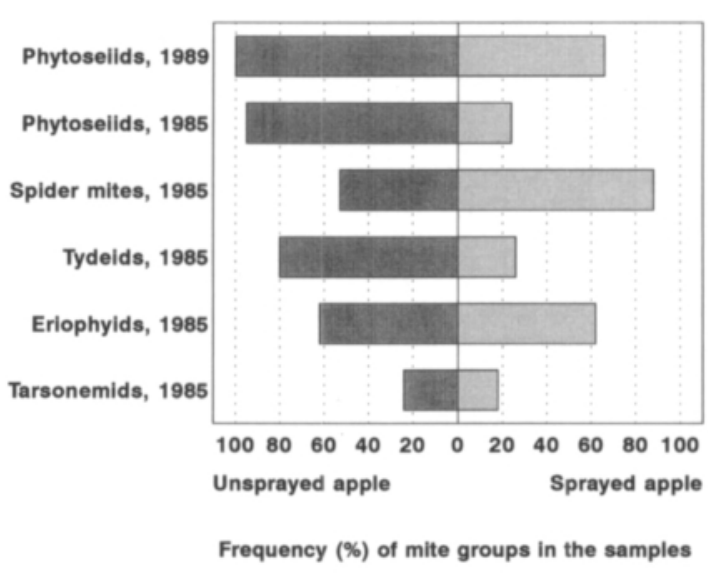

Fig. 2. Occurrence of mites in apple leaf samples in 1985 and 1989. (KROPCZYNSKA and TUOVINEN 1988, I, II).

earlier studies conducted in more favourable apple growingareas (COLLYER 1964, KNISLEY and SWIFT 1972, AMANO and CHANT 1990, THISTLEWOOD 


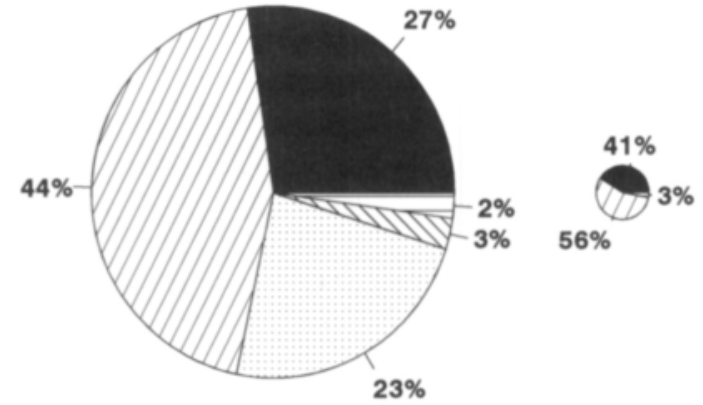

Unsprayed apple
Sprayed apple

\section{E. finlandicus $\square$ P. macropilis $\square$ P. soleiger

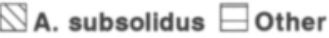

Fig. 3. Composition and relative abundance of phytoseiid mites in apple leaf samples in 1985. Relative numbers are based on identified subsamples if more than 100 mites were found. (KRopCZYNSKA and Tuovinen 1988, I).

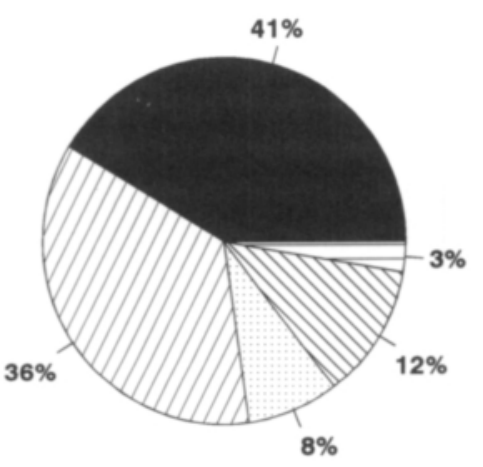

Unsprayed apple

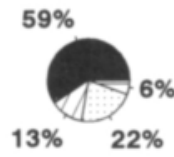

Sprayed apple
E. finlandicus $\square$ P. macropilis $\square$ P. soleiger A. subsolidus $\boxminus$ Other

Fig. 4. Composition and relative abundance of phytoseiid mites in apple leaf samples in 1989. (II)

1991). Many species of phytoseiid mites are also common on unsprayed apple trees in Norway, a country geographically and climatically close to Finland (EDLAND 1987).
The occurrence and number of phytoseiid mites on sprayed trees were low even though relatively few harmful sprays were used (Fig. 1, II). Phytoseiid mites have been found in higher densities in the USA, Canada and Europe, despite more numerous sprayings (LIENK et al. 1980, CROFT et al. 1990). This can be explained by the resistance to pesticides of $T$. pyri and Metaseiulus occidentalis (Nesbitt), the two predominant species in sprayed orchards in North America (CROFT and STRICKLER 1983). In Canada, THISTLEwOOD (1991) found a mean of 0.15 phytoseiids/leaf in 38 commercial orchards treated with a mean number of 4.5 insecticide and 2 acaricide sprays. In these orchards, the main species was Amblyseius fallacis Garman, which has not been recorded in the Nordic countries. This species is resistant to many commonly applied pesticides (CROFT and MEYER 1973, STRICKLER and CROFT 1982). Recently, up to 5fold resistance to azinphosmethyl and dimethoate has been noticed in Finnish colonies of $E$. finlandicus, collected from OP-treated trees, compared to colonies that never have been sprayed with insecticides (Tuomas Kostiainen, pers. comm.). Even though the observed resistance is not high compared to that found in A. fallacis, M. occidentalis or $T$. pyri, it might improve integrated mite control especially if lower concentrations of OPs can be applied.

$E$. finlandicus and $P$. macropilis were the most abundant phytoseiid species on both unsprayed and sprayed apple trees, and accounted for almost threequarters of all phytoseiid specimens (Figs. 3 and 4). The remaining quarter of the specimens included 10 species, of which Paraseiulus soleiger (Ribaga) was the most abundant one in 1985, but Amblyseius subsolidus Beglyarov in 1989. In 1985, the species found on sprayed trees consisted almost entirely of P. macropilis and E. finlandicus, whereas in 1989, $P$. soleiger was also present. The higher abundance of $P$. macropilis on sprayed trees in 1985 was deduced from a single sample containing $95 \%$ of the individuals of the species. E. finlandicus was found in $18 \%$ and $40 \%$ of sprayed samples, but $P$. macropilis was present only in $10 \%$ and $17 \%$ in 1985 and 1989, respectively.

Spider mite numbers, almost entirely P. ulmi, 
were significantly higher on sprayed trees than on unsprayed trees in 1985 (Fig. 1) (Mann-Whitney U-test, $\mathrm{z}=-4.58, \mathrm{~N}=79, \mathrm{P}<0.001$, calculated from scored values, $0=$ no mites, $1=1-5,2=6-10,3=$ $>11$ mites per leaf). The situation was exactly the same in 1989, when the number of $P$. ulmi was estimated in only part of the orchards (Mann-Whitney U-test, $\mathrm{z}=4.38, \mathrm{~N}=26, \mathrm{P}<0.001$, calculated from scored values). There were big differences between commercial orchards in the density of $P$. ulmi, even in orchards with similar spraying programmes. Spider mites caused continuous problems in some orchards, but in others, mite density was rather low. On untreated trees, though, spider mite density was consistently low, under 5 mites/leaf.

The mean of 15 mobile stages of mites/leaf in 1985 is considerably higher than the threshold for control of $P$. ulmi in the Netherlands, varying from $2 /$ leaf to $7 /$ leaf, depending on the time of season (RABBINGE 1985). There is no single economic injury level for apple, but many variable levels depending on growing conditions and weather, cultivars, and the presence of predatory mites (van de VRIE 1985, FrEIER et al. 1992, HARDMAN 1992). The maximum numbers of $P$. ulmi recorded in this study were as high as 105 and 95 mobile mites/leaf $(\mathrm{IV}, \mathrm{V})$. There is no doubt that $P$. ulmi causes severe injuries and yield losses in part of the commercial orchards. - The question of the economic injury level and the assessment of the spraying threshold are beyond the context of this study.

The numbers of the eriophyid mite A. schlechtendali were significantly higher on sprayed than on unsprayed trees in 1989 (MannWhitney U-test, $\mathrm{z}=-2.27, \mathrm{~N}=48, \mathrm{P}=0.024$, calculated from scored values), but not in 1985 (Fig. 1). Tydeid mites were observed only in 1985, and they were more numerous on unsprayed trees than on sprayed trees (MannWhitney U-test, $\mathrm{z}=-5.77, \mathrm{~N}=79, \mathrm{P}<0.001$ ) (Fig. 1). Tarsonemid mites were quite scarce, and they occurred equally on sprayed and unsprayed trees (Fig. 1).

Spider mites, eriophyids, tydeids and tarsonemids can serve as prey for many phytoseiid species. Of the pest mites, eriophyids such as A. schlechtendali can be considered advantageous for the bio- logical control of $P$. ulmi if their density is not so high that it causes bronzing of leaves or russeting of apples (EASTERBROOK and FULLER 1986, SOLHØY et al. 1991). On unsprayed trees, tydeid mites were even more common than spider mites. As tydeid mites feed on honeydew and Cladosporium fungi, pollen and various plant debris (GERSON 1985), they are not harmful to apple trees and are therefore considered a useful supplementary source of food for phytoseiid mites. In the Netherlands, tydeids were a more suitable food for $T$. pyri than for $A$. andersoni, but there may be differences between strains in the utilization of food sources (CALIS et al. 1988). The presence of alternative food sources, including pollen and other food of plant origin, for predatory mites is an important reason for continuing control of $P$. ulmi. KARG (1992) suggested that a common tydeid species, Tydeus caudatus (Ant. Duges), should be included in tests of the side effects of pesticides. As a representative of 'indifferent species', it may enhance control of $P$. ulmi by phytoseiid mites. In some of the acaricide tests and in the fungicide test tydeid mites were taken into account in this study (V, VI).

\subsection{Phytoseiid species and their relevance in integrated control}

The phytoseiid species found in this study are listed in Table 2. Three species imported to Finland and released in glasshouses are included (I).

In the following, the species considered important or interesting for the integrated control of phytophagous mites on apple trees in Finland are shortly characterized and discussed. There are many other species, which have only little value for the integrated control on apple trees, because they do not occur on apple trees or are very rare (I). Most of the articles on the use of phytoseiid mites in biological control concern Phytoseiulus persimilis Athias-Henriot, a species used in glasshouses for the control of T. urticae, or T. pyri, M. occidentalis, A. fallacis and A. andersoni, which are used for the control of $P$. ulmi in fruit orchards in USA, New Zealand and Europe. 
Table 2. Phytoseiid species recorded in Finland (I).

PHYTOSEIIDAE Berlese, 1916

PHYTOSEIINAE Berlese, 1916

Phytoseius Ribaga, 1902

Phytoseius juvenis Wainstein \& Arutunjan, 1970

Phytoseius macropilis (Banks, 1909)

Seiulus Berlese, 1887

Seiulus aceri (Collyer, 1957)

Paraseiulus Muma, 1961

Paraseiulus soleiger (Ribaga, 1902)

Paraseiulus talbii (Athias-Henriot, 1960)

Paraseiulus triporus (Chant \& Yoshida-Shaul, 1982)

Anthoseius De Leon, 1959

Anthoseius bakeri (Garman, 1948)

Anthoseius rhenanus (Oudemans, 1905)

Anthoseius richteri (Karg, 1970)

Anthoseius suecicus (Sellnick, 1958)

Anthoseius viktorovi Wainstein, 1975

Typhlodromus Scheuten, 1857

Typhlodromus andrei Karg, 1982

Typhlodromus laurae Arutunjan, 1974

Typhlodromus pyri Scheuten, 1857

AMBLYSEIINAE Berlese, 1916

Phytoseiulus Evans, 1952

Phytoseiulus persimilis Athias-Henriot, 1957

Proprioseiopsis Muma, 1961

Proprioseiopsis okanagensis (Chant, 1957)

Euseius Wainstein 1962

Euseius finlandicus (Oudemans, 1915)

Amblyseius Berlese 1914

Amblyseius barkeri (Hughes, 1948)

Amblyseius cucumeris (Oudemans, 1930)

Amblyseius reductus Wainstein, 1962

Amblyseius subsolidus (Beglyarov, 1960)

Amblyseius tenuis (Hirschmann, 1962)

Amblyseius zwoelferi (Dosse, 1957)

\section{Phytoseius macropilis (Banks)}

P. macropilis was common on various deciduous trees and bushes. Together with E. finlandicus, it was one of the two most common species on apple tree. The two species often occurred on the same trees and even on the same leaves in equal numbers. $P$. macropilis occurred on leaves with high numbers of tydeid and eriophyid mites, and lower numbers of $P$. ulmi or tarsonemids (Table 3).

Feeding studies on $P$. macropilis have shown that it developed more rapidly when fed $P$. ulmi or the astigmatid mite Czenspinskia lordi Nesbitt than on $T$. urticae. Tydeid mites were not suitable food at all (DOSSE 1956). HERBERT (1959) listed the following prey species for P. macropilis: P. ulmi, summer eggs, larvae, nymphs and adults; Bryobia arborea M. \& A., summer eggs, nymphs and adults; Tetranychus telarius (L.), eggs and nymphs; A. schlechtendali, adults. In the laboratory studies of KROPCZYNSKA-LINKIEWICZ (1973), P. macropilis developed most rapidly when fed on $A$. schlechtendali $(8.9 \mathrm{~d})$, followed by P. ulmi $(9.6 \mathrm{~d})$ and $T$. urticae $(10.3 \mathrm{~d})$. All these diets resulted in the same egg-laying intensity (16.2-16.9 eggs/female). KoZLOWSKI and KOZLOWSKA (1991) found that $P$. macropilis consumed 33.7 rust mites per day, twice as much as did E. finlandicus. The fecundity of $P$. macropilis was 7.1 eggs in 5 days period, about the same as that of E. finlandicus.

Amano and Chant (1990) found that $P$. macropilis formed a rather simple and stable preypredator system in an abandoned orchard throughout a three-year research period. The available prey species consisted of tydeids, eriophyids and tetranychids; the other common phytoseiid in that orchard was E. finlandicus.

$P$. macropilis is important for the integrated control of phytophagous mites on apple trees in Finland. It was relatively more common on unsprayed trees than on sprayed trees. This difference may be due to its locomotory habits, which may slow down its ability for aerial distribution and thus resettling of sprayed trees (III). The observation that $P$. macropilis is common on leaves with abundant hairs on the undersurface, and less common on plants with smooth leaves may also mean poorer chances for coincidental aerial distribution if the hairs arrest the animals (COLLYER 1956).

\section{Paraseiulus soleiger (Ribaga)}

This species was widespread and sometimes occurred in high numbers. It was found on numerous deciduous trees and bushes, and on apple trees 18\% of the phytoseiids belonged to this species. P. soleiger occurred on unsprayed and, to some extent, also on sprayed trees. It was found on trees with relatively high numbers of tydeid mites but $P$. ulmi, A. 
Table 3. Mites associated with phytoseiid species on apple trees. Based on observations on unsprayed apple trees in $1985-1989$. - not observed; + observed occasionally, in low numbers; ++ observed regularly, in low or moderate numbers; +++ observed in high numbers

\begin{tabular}{|c|c|c|c|c|c|}
\hline Phytoseiid species & P. ulmi & Tydeid. & Erioph. & Tarson. & Other phytoseiids $^{1)}$ \\
\hline Phytoseius macropilis & + & +++ & +++ & + & All other species ${ }^{2)}$ \\
\hline Paraseiulus soleiger & + & ++ & ++ & + & All other species ${ }^{2)}$ \\
\hline P. talbii & - & + & + & - & $\begin{array}{l}P . \text { soleiger } \\
P . \text { macropilis } \\
P . \text { triporus }\end{array}$ \\
\hline P.triporus & + & +++ & + & + & $\begin{array}{l}\text { P. macropilis +++ } \\
\text { E. finlandicus +++ } \\
\text { P. soleiger }+++ \\
\text { A. rhenanus }+ \\
\text { A. subsolidus }+\end{array}$ \\
\hline Anthoseius bakeri & + & ++ & ++ & + & $\begin{array}{l}\text { P. macropilis } \\
E . \text { finlandicus } \\
P . \text { soleiger } \\
\text { A. suecicus }\end{array}$ \\
\hline A. rhenanus & - & ++ & - & - & $\begin{array}{l}\text { P. macropilis }+++ \\
\text { E. finlandicus }++ \\
\text { P. soleiger }+ \\
\text { A. reductus }+ \\
\text { A. subsolidus }+\end{array}$ \\
\hline A. richteri & + & +++ & + & - & $\begin{array}{l}\text { P. macropilis +++ } \\
\text { E. finlandicus +++ } \\
\text { P. soleiger }+ \\
\text { A. subsolidus }+ \\
\text { A. reductus }+\end{array}$ \\
\hline A. suecicus & - & + & - & - & $\begin{array}{l}\text { P. macropilis } \\
P . \text { soleiger } \\
\text { E. finlandicus }\end{array}$ \\
\hline A. viktorovi & + & + & + & - & P.triporus \\
\hline Euseius finlandicus & + & ++ & +++ & + & All other species ${ }^{3)}$ \\
\hline Amblyseius reductus & + & ++ & + & - & $\begin{array}{l}\text { E. finlandicus +++ } \\
\text { P. macropilis +++ } \\
\text { P. soleiger ++ } \\
\text { A. subsolidus }+ \\
P . \text { triporus }+\end{array}$ \\
\hline A. subsolidus & + & +++ & + & - & $\begin{array}{l}\text { P. macropilis }+++ \\
\text { E. finlandicus +++ } \\
\text { P. soleiger }+ \\
\text { P. triporus }+ \\
\text { A. rhenanus }+ \\
\text { A. richteri }+ \\
\text { A. reductus }+\end{array}$ \\
\hline
\end{tabular}

\footnotetext{
${ }^{1)}$ In cases of only a few observation, only species list is given. If only single specimen of a spieces was found, it is omitted.

${ }^{2)}$ Except $A$. viktorovi.

${ }^{3)}$ Except $A$. viktorovi and $P$. talbii.
} 
schlechtendali and tarsonemids were also present (Table 3).

According to DOSSE (1956), $P$. soleiger is rather specialized, with tydeid mites being its main food source. It cannot complete its development if $P$. ulmi or T. urticae are the only food source. Because of its relatively high abundance, $P$. soleiger can be an important species on apple, although its prey consists mostly of mites other than $P$. ulmi.

\section{Anthoseius rhenanus (Oudemans)}

This species was found in abundance on strawberry and, in smaller amounts, on many trees and bushes, including apple trees. HERBERT (1959) listed the following prey species for A. rhenanus: P. ulmi, summer eggs, larvae, nymphs and adults; B. arborea, summer eggs, nymphs and adults; $T$. telarius, eggs and nymphs; A. schlechtendali, adults. In feeding tests, conducted by KOZLOWSKI and KOZLOWSKA (1991), A. rhenanus consumed 32.7 apple rust mites per day, which was twice as much as was the consumption of E. finlandicus. On the eriophyid diet, the fecundity of $A$. rhenanus was also higher than that of E. finlandicus, P. macropilis or T. pyri.

Because of its scarce occurrence on apple trees, A. rhenanus did not appear to be important for the integrated control of mites on apple. Its role as natural enemy of spider mites, eriophyid mites, and the strawberry mite Phytonemus pallidus ssp. fragariae (Zimm.) is obviously more important on strawberry and other berry plants (TuOVINEN 1992b).

\section{Typhlodromus pyri Scheuten}

This species was found in only one location in Åland, on black currant, and even there in low density. It is commonly used in integrated control programmes all over the world, especially because there are resistant strains to OP insecticides (HOYT 1972). Because T. pyri has not been found on apple trees or any other trees in Finland it is possible that its relatively poor resistance to severe frost prevents it from overwintering on tree trunks or branches above the snow cover (MacPHEE 1963). The occurrence of the species in Alland, where the climate is more favourable shows that there may be possibilities to the utilization of the species in that area. In Norway, T. pyri is common on apple trees (EDLAND 1987).

In the laboratory studies by KROPCZYNSKALINKIEWICZ (1973), T. pyri developed most rapidly when fed on $T$. urticae $(9.5 \mathrm{~d})$, followed by $A$. schlechtendali (10.4) and P. ulmi (10.9 d). A considerably longer development time was needed with Bryobia rubriocolus (Scheuten) (13.7 d). The diets resulted in an egglaying rate of 7.1 (T. urticae) to 10.1 (P. ulmi) eggs per female. KoZLOWSKI and KOZLOWSKA (1991) found that $T$. pyri consumed 36.3 eriophyids per day, more than the consumption of other phytoseiids (e.g. P. macropilis, A. rhenanus and E. finlandicus). However, the fecundity of $T$. pyri was lower on the eriophyid diet than that of other phytoseiids.

Resistant strains of $T$. pyri could be used in Finland as an introduced natural enemy. Introductions may have to be repeated, at least after hard winters. $T$. pyri is an interesting species, whose competence and importance may be increased by climatic change.

\section{Euseius finlandicus (Oudemans)}

This species was common and it was the most widely distributed species on deciduous trees and bushes. It has been recorded on numerous trees and bushes, less frequently on herbaceous plants, all over the world (de MORAES et al. 1986).

HERBERT (1959) listed the following prey species for E. finlandicus: P. ulmi, summer eggs, larvae, nymphs and adults; $B$. arborea, summer eggs, nymphs and adults; T. telarius, eggs and nymphs; A. schlechtendali, adults. In the laboratory studies of KROPCZYNSKA-LINKIEWICZ (1973), E. finlandicus developed most rapidly when fed on $P$. ulmi (7.6 d), followed by B. rubriocolus (7.7 d), T. urticae $(8.9 \mathrm{~d})$ and $A$. schlechtendali $(10.8 \mathrm{~d})$. Spores and hyphae of the apple mildew Podosphaera leucotricha Ellis \& Everh. appeared to be suitable food 
for $E$. finlandicus, and it developed and reproduced normally on this diet (10.7 d and 9.5 laid eggs/female). The other diets resulted in an egg laying intensity of 7.2 (T. urticae) to 15.6 (A. schlechtendali) eggs per female. DICKE et al. (1988) showed that $E$. finlandicus preferred $A$. schlechtendali to $P$. ulmi as food. KOZLOWSKI and KOZLOWSKA (1991) found that starving females of $E$. finlandicus consumed as many eriophyids as other phytoseiids (e.g. T. pyri, A. rhenanus, $P$. macropilis), but their normal consumption was significantly lower than that of other phytoseiids. SCHAUSBERGER (1990) compared the pollen of various plants as a food source for E. finlandicus and found that birch and cherry pollen were satisfactory food for reproduction.

E. finlandicus was relatively more abundant in sprayed orchards than on unsprayed trees (Figs. 3 and 4). This pattern is attributed to its active moving habits, which facilitate aerial distribution, rather than to its possible resistance to pesticides (III). On unsprayed apple trees, E. finlandicus can effectively control P. ulmi (CHANT 1959, GRUYS 1982, SECHSER et al. 1984), but in sprayed orchards it is considered less important than other, resistant phytoseiid species (GRUYS 1982, THISTLEWOOD 1991). AMANO and CHANT (1990) noted that E. finlandicus formed a stable population in a single unsprayed apple tree, where, together with $P$. macropilis, it regulated phytophagous mite populations. It is also common in Italian peach orchards, where it is regarded as an efficient natural enemy of P. ulmi. However, it is more sensitive to OP-pesticides than A. andersoni, which is common in Italy (Duso 1992). E. finlandicus is a competent species which is well adapted to different environmental conditions. It is an important predator of phytophagous mites on apple in Finland.

\section{Amblyseius reductus Wainstein}

This species was found on several species of trees, bushes and herbs. It occasionally occurred in rather high densities on apple trees, and was found on apple leaves inhabited by tydeid mites and, in lesser amounts, by eriophyids, $P$. ulmi and tarsonemids (Table 3). ToKunOva and Malov (1988) used $A$. reductus to control spider mites on strawberry in Russia. Although A. reductus is not widely distributed it may be relevant for the integrated control of mites on apple trees.

\section{Amblyseius subsolidus (Beglyarov)}

This species was found on apple trees, hawthorn and bird cherry. Although $4.5 \%$ of the phytoseiids on apple trees belonged to this species, it occurred only in a few localities. A. subsolidus was found on apple leaves inhabited by tydeid mites and, in lesser amounts, by eriophyids and P. ulmi (Table 3). A. subsolidus occasionally occurred in relatively high numbers on apple trees, and it can be an important species for the integrated control in some areas.

\subsection{The role of phytoseiid mites on apple trees}

Unsprayed apple trees contain numerous species of mites at different trophic levels. In this study unsprayed apple trees usually contained more than a single phytoseiid species, most often $2-4$ species. The two most common species, $P$. macropilis and $E$. finlandicus, frequently occurred together, and both of them can be predominant species on apple (Figs. 3 and 4).

In a comprehensive study of the occurrence of predatory mites and prey species in an apple orchard, KARG (1972) found negative correlations between the number of predatory mites and prey mites, mainly $P$. ulmi and A. schlechtendali. The main species in his study was Typhlodromus tiliarum (Oudemans), which is not found in Finland, but E. finlandicus was also present. The correlation between $E$. finlandicus and A. schlechtendali was more evident than that between the former and $P$. ulmi. T. tiliarum was the predominant species for the first two years and E. finlandicus in the third year. KARG (1972) concluded that if $50 \%$ of leaves were inhabited by predatory mites, spider mites would not be able to build up gradations. The observations found in the present study that numbers of $P$. ulmi were very low if phytoseiid numbers exceeded $0.5 /$ leaf are consistent with his conclusion. 
Many phytophagous and fungivorous mites serve as food sources for predatory mites. In Canada, AMANO and CHANT (1990) found 20 mite species occurring in an abandoned orchard, but, remarkably, no specimens of $P$. ulmi or T. urticae, the pest mites most common in commercial orchards in Canada. Instead, two other tetranychid species were present, with their highest density being 6 mites/leaf. Nine phytoseiid species were found, and three of them, E. finlandicus and P. macropilis in the abandoned orchard, and Typhlodromus pomi (Parrott) in a big isolated apple tree, occurred abundantly. There is considerable difference in species dominance in both sprayed and unsprayed trees between eastern and western North America (AMANO and CHANT 1990). In Finland, there are often marked differences in phytoseiid species compositions between different apple tree individuals even in the same locality. These differences may partly be due to the difference in leaf structures, such as to the degree of hairiness, between apple cultivars. Other factors, such as the presence of other predators and the availability of other food such as pollen may also affect the dominance and stability of the phytoseiid species.

According to WALDE et al. (1992), even when a specialist predator shows stronger numerical and functional responses to increases in its prey, a generalist predator such as T. pyri, can be as effective as a specialist. Moreover, a generalist can survive even if its principal prey is exterminated. High predator-prey ratios are often needed to control spider mites at low prey densities. The major impact of the generalist phytoseiid may be at low prey densities on perennial crops such as apple, when population fluctuations are limited to low amplitudes (McMURTRY 1992). The generalist phytoseiids are probably not able to 'catch up' from low predator-prey ratios to suppress the rapidly increasing spider mite population. However, such an ability has been noticed in A. andersoni vs. P. ulmi (IVANCICH GAMBARO 1986). Observations of the common Finnish generalist phytoseiids, E. finlandicus and $P$. macropilis, show that their populations can grow large in one season but that the suppression of a large $P$. ulmi population needs a longer period than one season, finally resulting in a high predator-prey ratio (Tuovinen, unpubl.). In natural conditions, this final situation is a result of many components, including natural enemies other than phytoseiid predators (CHAZEAU 1985).

The effect of a multi-species predator complex on a multi-species complex of phytophagous mites may be more stable than that of a single predator species, as the differences in prey and feeding habits can stabilize the prey-predator system. The unsprayed trees in this study were normally inhabited by 2-4 species of phytoseiids, which facilitate good adaptability to a changing prey complex. CROFT et al. (1992) studied the effect of mixed populations of $M$. occidentalis and T. pyri on three phytophagous mites. They found that control was as good as or better than with a single phytoseiid species. Therefore, a high diversity of phytoseiid species in and around orchards is generally an advantage in the natural control of phytophagous mites. The interactions of $E$. finlandicus and $P$. macropilis were studied by AMANO and CHANT (1990), who found rather stable predatory mite populations in unsprayed apple tree habitats. Cannibalism occurs among phytoseiids, and interspecific predation is also probable, but these should be thought as a way of surviving rather than as a self-destructive habit (cf. CROFT et al. 1992). A multi-species predator complex may tolerate pesticides better than a single-species system, even if no resistance occurs, because at the time of harmful spraying different species may be at different developmental phases and thus may have different tolerance to pesticides. Furthermore, behavioural differences may also be important when tolerance to pesticides is concerned. These aspects need to be studied more precisely in Finnish conditions.

The low density of phytoseiid mites noted on sprayed apple trees and the high density of $P$. ulmi show that the pesticide treatments normally applied in commercial orchards are destructive to all phytoseiid species occurring in this country but have no, or only a small, effect on $P$. ulmi. Although the number of insecticide sprays harmful to phytoseiid mites is low in Finnish apple orchards, 2.1 - 3.7 per season (TUOVINEN 1992a), it is enough to keep the phytoseiid density low. There is urgent need for insecticides that are safer to phytoseiid mites, and 
also for better knowledge of spraying thresholds to avoid unnecessary sprayings (cf. HESJEDAL 1990).

OP-resistant phytoseiid strains have been widely used in IPM programmes, most commonly $T$. pyri in Europe and A. fallacis in North America. The presence of T. pyri in Åland shows that this species could be utilized in Finland, although it obviously needs to be introduced into apple orchards. The prospects of finding OP-resistant strains in our most common species, E. finlandicus, may be limited, because of the lower amount of detoxifying enzymes, compared to those phytoseiids in which resistance occur (ŠULA and ZACHARDA 1991). Therefore, the recent finding of 5-fold differences between Finnish E. finlandicus colonies in resistance to azinphosmethyl and dimethoate is interesting (Tuomas Kostiainen, pers. comm.). Finding or breeding more resistant strains is important, and even a lower level of resistance could be satisfactory, especially if low concentrations of insecticide sprays can be applied (cf. HESJEDAL 1990).

\section{Surrounding vegetation as a source of phytoseiid mites}

Phytoseiid mites occurred on a wide range of host plants (I, II). The favoured host plants, or those on which more than 1 phytoseiid mite/leaf were found, include the following bushes and trees: Aesculus hippocastani, Aristolochia macrophylla, Corylus avellana, Fragaria vesca, Fraxinus excelsior, Juglans cinerea, Pterocarya rhoifolia, Ribes nigrum, Rubus odoratus, Sorbus aucuparia, $S$. thuringiaca, Tilia x euchlora and Ulmus glabra. Owing to the shortage of samples in this study, the above plants are only examples of good host plants; the material does not permit their relative order in suitability as hosts to be calculated statistically. There are certainly many other trees, bushes and herbaceous plants which may be of great value as hosts for phytoseiid mites. However, phytoseiid mites were not found on the most common deciduous trees in Finland, Betula pubescens and B. verrucosa (III).

The same two species, E. finlandicus and $P$. macropilis, that were common on apple trees were the most common on most of the other trees and bushes, too (II). Only Seiulus aceri (Collyer) was found to be strictly related to a certain host plant, Acer platanoides.

Adjacent vegetation had some effect on the phytoseiid densities and species compositions found on apple trees, although local differences were meaningful (III). Great differences in phytoseiid population size between individuals of the same host plant species can even occur in the same locality. Phytoseiids usually occurred only occasionally in sprayed orchards with only a few good adjacent host plants but more abundantly in orchards surrounded by suitable host plants. $P$. macropilis was the predominant species on unsprayed apple trees, but $E$. finlandicus was more common in sprayed orchards. In general, this difference should not, however, be understood as resistance to pesticides in E. finlandicus populations but rather as better dispersing capacity (III).

In a 2-ha orchard surrounded by deciduous trees and bushes, phytoseiid density was high (0.3$3.1 /$ leaf) only 15 days after a spraying with dimethoate (III). Phytoseiid mites were encountered in the vicinity of the orchard on the following trees and bushes: Prunus padus (0.3 mites/leaf), C. avellana (9.8/leaf), Lonicera xylosteum (2.7/leaf), Tilia cordata (2.4/leaf), Quercus robur (1.2/leaf) and Salix caprea (0.8/leaf). In the same orchard, $E$. finlandicus was the dominant species on both apple trees and other host plants, with the exception of $S$. caprea, on which P. macropilis was dominant. Both E. finlandicus and P. macropilis were common also on plants where spider mites were scarce (III).

The capacity of phytoseiids for long-distance airborne dispersal is obviously quite high, and smaller orchards or blocks may be rapidly recolonized after the application of harmful sprays if host plants inhabited by phytoseiids are nearby. Tall trees, such as oak, lime and elm appear to be more important than low bushes as natural sources of phytoseiids in aerial dispersal (III). HoY et al. (1985) noted that phytoseiid mites can disperse at least $200 \mathrm{~m}$, probably even further, via air turbulence. There are certainly differences in the dispersal capacity of phytoseiid species, due to their locomotory habits 
and activity. An actively moving species such as $E$. finlandicus obviously can migrate more rapidly from adjacent vegetation than $P$. macropilis, which moves slowly and tends to hide under hairs.

Relatively large numbers of phytoseiid mites, mainly $E$. finlandicus and $P$. macropilis, were found in samples with very few phytophagous mites (II). The availability of animal food is not a prerequisite for the occurrence of phytoseiid mites. The same was observed by IVANCICH GAMBARO (1988) in Italian fruit orchards in the case of $\mathrm{Am}$ blyseius aberrans Oudemans.

BOLLER et al. (1988) studied hedges as a potential source of phytoseiid mites and found that high densities of $T$. pyri were regularly present on Rubus fruticosus, and lower densities on C. avellana, Cornus sanguinea and L. xylosteum. They concluded that hedges upwind of vineyards could act as sources of $T$. pyri provided a plant community of suitable composition was available. The same conclusion is drawn from the present studies for $E$. finlandicus in Finnish apple orchards (II, III).

The artificial introduction of phytoseiid mites into fruit orchards has been attempted on numerous occasions (SOLOMON 1986, WILDBOLZ and STAUB 1986, WILDBOLZ 1988, BolLER and REMUND 1991). However, establishing a new phytoseiid community is not always a simple task. In France, FAUVEL and GENDRIER (1992) reported that the introduction of $A$. andersoni and $T$. pyri into vineyards with the aid of vine canes or branches of hackberry (Celtis australis) did not succeed. They presented several possible reasons for the failure: excessive susceptibility of the 'wild' phytoseiid strain to the sprays still necessary; insufficient release numbers; release at the wrong time; competition of other phytoseiid species; too short duration of observations. However, none of the above reasons fully explained the failure; other climatic or environmental conditions might provide a more satisfactory explanation. In Hungary, JENSER et al. (1992) tried unsuccessfully to introduce $E$. finlandicus into an orchard treated only with harmless pesticides. They attributed the failure mainly to the lack of alternative food in the orchard. Under Finnish conditions, birch pollen, which is good food for E. finlandicus (SCHAUSBERGER 1990), is available on apple leaves from early May to June-July, promoting the survival of immigrant phytoseiids.

Natural immigration can lead to a rapid establishment of phytoseiid mites in orchards surrounded by suitable host plants provided that the application of harmful sprays is discontinued. This was recently observed in an experimental block of 0.5 ha which had earlier been sprayed with azinphosmethyl and dimethoate but in which no harmful sprays were applied in 1991-1992. The phytoseiid population, mainly $E$. finlandicus, but also $P$. macropilis, grew from zero to over 3/leaf during the first season after spraying was discontinued. Another example is a young apple block of 100 trees planted in 1990 where small numbers of phytoseiids were found only one year after planting (Tuovinen, unpubl.).

The increasing diversity of plants around orchards can be hazardous because attacks by polyphagous pests such as the winter moth $O$. brumata or leaf miners can become more frequent (WILDBOLZ 1992). Therefore trees or bushes should not be conserved or planted near apple trees without careful consideration. The phytoseiid species composition on some trees and bushes is similar to that on unsprayed apple trees, which should be seen as an advantage for using those plants (II). A good example of such a plant is hazel C. avellana.

The effect of ground-cover plants in apple orchards on phytoseiid fauna was not studied in the present context. In Austria, FISCHER-COLBRIE and EL-Borolossy (1989) found phytoseiid mites on many herbs, e.g. Galeopsis, Lamium, Polygonum, Stellaria and Aegopodium, that are common weed species in Finland. The phytoseiid species found in their study are not the same as those found on apple trees in Finland but are the same as those on fruit trees in Austria. Phytoseiids can employ as food $T$. urticae, a species that is common on grasses, and pollen, which is available throughout the season. No phytoseiids were found in conventionally sprayed orchards but they were common in IPM or abandoned orchards (FISCHER-COLBRIE and ELBOROLOSSY 1989). It would be advisable to study the influence of ground-cover plants on phytoseiid mite numbers on apple in Finnish conditions, too. 


\section{Pesticides in mite management}

In the course of the studies many observations were made on the effect of pesticides on predatory and phytophagous mites, e.g. in the chemical control studies (IV, V, VI), the surveys of phytoseiid species (II) and the study on the effect of surrounding vegetation (III). These observations are taken into account in the following evaluation of selected pesticides.

Ideally, acaricides should no longer be needed when integrated pest management methods are adopted. Therefore, acaricides should be considered as a reserve measure, and should be applied only in the event of serious disturbances in the IPM system. They may have to be used at the start of IPM to lower the initial mite populations. Later, occasional pest problems may have to be controlled by broad-spectrum pesticides, which disturb the mite stability and may cause outbreaks of phytophagous mites. If only a very limited arsenal of efficient and 'phytoseiid-safe' pesticides is available, acaricides may be needed more frequently than if a higher number of selective pesticides were in use.

\subsection{Acaricides}

In acaricide tests, chinomethionate, dicofol, fenbutatinoxide, mineral oil and oxydemetonmethyl were used as reference acaricides (IV, V). The use of dicofol has not been allowed since 1992, and chinomethionate is reported by advisors and growers alike to be ineffective in many orchards. In control experiments, the reference acaricides were seldom as effective as the test acaricides, but in most cases, $P$. ulmi could be satisfactorily controlled by them, too, but two or even three treatments might be necessary (IV).

The use of novel acaricides in the integrated control of phytophagous mites is evaluated briefly in the light of their effectiveness on target mites, and their influence on phytoseiid mites. As resistance in $P$. ulmi to clofentezine and hexythiazox has already been noticed (THWAITE 1991, REISSIG and Hull 1991), it is essential that they be used in integrated control only to lower initially high mite numbers and thus to assist phytoseiids and other predators to have better possibilities to maintain control. The real need for chemical control should therefore be carefully evaluated before treatment (CROFT et al. 1987).

Mineral oils are not currently used in Finnish commercial apple orchards, mainly because, as 'weather sensitive' pesticides, their effectiveness is not guaranteed. Pure paraffin oil is only slightly harmful to phytoseiid mites (FISCHER-COLBRIE and ElBOROLOSSY 1988).

\subsubsection{Flubenzimine}

Good control of $P$. ulmi was achieved with flubenzimine when sprayed just before or during blossom and, if necessary, in late June or July. Later treatments resulted in a low overwintering population, facilitating mite control in the next season, too. Several applications in lower concentrations (25-85 g a.i./100 1 water) gave almost complete control of P. ulmi (IV).

Flubenzimine was effective against $A$. schlechtendali (IV). SCHLIESSKE (1989) also found flubenzimine to be effective against $A$. schlechtendali, but, in Germany, VoGT et al. (1990) found that a single spray of flubenzimine had only a temporary effect against $A$. schlechtendali.

Flubenzimine was harmful to phytoseiid mites, and even one spray diminished numbers of $E$. finlandicus and $P$. macropilis. When flubenzimine was sprayed several times during the season, phytoseiids disappeared almost entirely (IV). VIGL et al. (1985) proposed that flubenzimine should not be used against $P$. ulmi because of its harmful effect on the phytoseiid mites $T$. pyri and A. andersoni. SEIER (1989) studied the effect of $500 \mathrm{ppm}$ flubenzimine on females of A. andersoni and T. pyri, and found a $50 \%$ and $15 \%$ mortality, and a $63 \%$ and $54 \%$ reduction in egg-laying intensity, respectively. Egg hatching was affected only slightly, but during the development of larvae and nymphs, the mortality rate was $75 \%$ and $47.5 \%$, respectively. HASSAN et al. (1991) rated flubenzimine as moderately harmful to E. finlandicus and T. pyri. VoGT (1992) sug- 
gested that flubenzimine might have disturbed the development of predatory anthocorid larvae.

Flubenzimine is an effective acaricide, but because of its toxicity to phytoseiid mites and, possibly, other natural enemies, it should not be used in the integrated control of $P$. ulmi. Exceptionally, it can be used to reduce the high initial density of both P. ulmi and A. schlechtendali before starting the integrated mite control.

\subsubsection{Clofentezine}

Clofentezine was introduced as an ovo-larvicidal acaricide specifically for spider mite control (BRYAN 1981). Laboratory tests showed that when sprayed on $P$. ulmi winter eggs early, that is, at the beginning of their spring development, clofentezine was more effective than when sprayed later. In field tests, clofentezine was effective when sprayed before the beginning of embryonic development of winter eggs (V). MARSHALL and PREE (1991) achieved $100 \%$ mortality of young summer eggs and nymphs with a 25 ppm clofentezine concentration, whereas not even 1000 ppm concentration was toxic to adults. In laboratory tests conducted on peach leaves by PREE et al. (1992), clofentezine retained its high effectiveness on summer eggs of $P$. ulmi for 10 days, and some effectiveness for at least 30 days, suggesting that satisfactory control could be achieved with a single summer spray.

When sprayed five times on trees with low density populations of $P$. ulmi, in accordance with the apple scab spraying schedule, clofentezine significantly diminished the numbers of phytoseiid mites, but did not totally eliminate them (V). Repeated summer sprays affected the numbers of $A$. schlechtendali. Repeated sprays should be avoided because they may accelerate the development of resistance (cf. MARSHALL and PREE 1991). VOGT (1992) found that one early spring spray had no effect on A. schlechtendali, but was successful against $P$. ulmi. In the $\mathrm{UK}$, clofentezine suppressed A. schlechtendali to some extent but had little effect on the phytoseiid $T$. pyri, which kept eriophyid densities at a much lower level in clofentezine plots than in plots where phytoseiid numbers were greatly reduced (EASTERBROOK 1984).

SEIER (1989) studied the effect of $150 \mathrm{ppm}$ clofentezine on the phytoseiid mites A. andersoni and $T$. pyri, and found no initial toxicity to females, but an almost $50 \%$ reduction in egg-laying intensity. Egg hatching was only slightly impaired, and the development of larvae and nymphs was normal. HASSAN et al. (1991) classified clofentezine as an acaricide harmless to phytoseiid mites and almost all other natural enemies included in the IOBC/WPRS working group's testing programme. Clofentezine is an effective and relatively safe acaricide for integrated control on apple. It should be applied before P. ulmi winter egg hatching (V).

\subsubsection{Hexythiazox}

Hexythiazox is toxic primarily to eggs and early nymphal stages of $P$. ulmi (WELTY et al. 1988). In laboratory tests, 50 and 100 ppm hexythiazox diminished the hatching of undeveloped $P$. ulmi winter eggs ( 92 and $99 \%$ effect, respectively), but the effect was poor when sprayed after the eggs had already started to develop. In field tests, hexythiazox was effective when sprayed in spring during the winter egg hatching period (V). MARSHALL and PREE (1991) achieved 100 and $79 \%$ mortality in young summer eggs with 1000 and 25 ppm concentrations, respectively, and $99 \%$ mortality in nymphs with a $25 \mathrm{ppm}$ concentration. However, even a $1000 \mathrm{ppm}$ concentration was not toxic to adults. PREE et al. (1992) studied the persistence of the effectiveness of hexythiazox on summer eggs of $P$. ulmi in the laboratory, and found that a good effect persisted for 20 days, and some effect for at least 30 days. The long-lasting effect of hexythiazox also in field conditions was found in the present study, where good control of P. ulmi was gained with a single summer spray (V).

Repeated summer sprays did not have any effect on A. schlechtendali (V). In Germany, VoGT (1992) reported good control of $P$. ulmi and $A$. schlechtendali with hexythiazox sprayed early in the spring; however, the concentration of the spray was not given.

When sprayed five times on trees with low density populations of $P$. ulmi, in accordance with the 
apple scab spraying schedule, hexythiazox significantly diminished the numbers of phytoseiid mites but did not totally eliminate them $(\mathrm{V})$.

Hexythiazox is an effective acaricide against $P$. ulmi but not against A. schlechtendali. It is also relatively safe for phytoseiid mites (BOWER 1990, HASSAN et al. 1991, VOGT 1992). It can be used either during the egg hatching period in May, before the adults have emerged, or in summer. Repeated sprays should be avoided to avoid the development of resistance (THWAITE 1991).

\subsection{Insecticides}

As a rule, insecticide sprays are harmful to phytoseiid mites but do not prevent an increase of $P$. ulmi. If insecticides were used, with a few exceptions, the number of phytoseiid mites would be low but those of $P$. ulmi high, and, conversely, if no insecticide sprays were applied, the numbers of $P$. ulmi would be low, but phytoseiid mites would be found in almost every sample (II, III).

The harmful effect of most insecticides on phytoseiid mites is well known (BOLLER et al. 1989). Only a few phytoseiid species have been found to be resistant to the insecticides commonly used. $T$. pyri is the only species reported to be resistant that occurs in Finland, but it has not yet been found on apple trees (I). Even so, the possible resistance to most common insecticides in Finnish phytoseiid strains is worth to study. The recent finding of resistance to azinphosmethyl and dimethoate in $E$. finlandicus colonies is a good start for those studies (Tuomas Kostiainen, pers. comm.).

In Norway, very low concentrations, $1 / 30-1 / 5$ of the normal rates of the insecticides azinphosmethyl, fenitrothion and oxydemetonmethyl, are recommended for integrated plant protection in apple orchards, mainly to conserve predatory bugs, coccinellids and lacewings (HESJEDAL 1990). However, even such low concentrations may not save native phytoseiid populations, and an attempt is now being made to introduce OPresistant $T$. pyri strains in Norwegian orchards (Torgeir Edland, pers. comm.).

The insect growth regulator (IGR) diflubenzuron is widely used in IPM programmes and is harmless to phytoseiid species (KUIJPERS 1992). However, it has not been efficient enough against the apple fruit moth A. conjugella (Tuovinen, unpubl.). Therefore, other IGR and ICR (insect chitinsynthesis regulator) insecticides should be tested to find efficient but 'phytoseiid-safe' insecticide against this key pest.

As most of the samples were collected in AugustSeptember, the interval between harmful sprays and sampling date was quite long, usually more than one month. Most of the phytoseiid specimens found in sprayed orchards are thought to have originated from surrounding unsprayed vegetation. Therefore, the results of this study cannot be used to evaluate in detail the effect of different spraying programmes on phytoseiid mite densities.

\subsection{Fungicides}

\subsubsection{Bitertanol}

In laboratory tests direct spray of $125 \mathrm{ppm}$ bitertanol had only a slight or non-significant effect on $P$. ulmi larvae; it had no effect on winter egg hatching, either (VI). In a field experiment, four sprays with bitertanol in June-July caused a slight non-significant increase in numbers of $P$. ulmi, but did not affect Eriophyidae, Tydeidae or Phytoseiidae.

In field tests, bitertanol was harmless to $E$. finlandicus (VI). SEIER (1989) found no initial toxicity with $125 \mathrm{ppm}$ bitertanol to females of $A$. andersoni and $T$. pyri, but the spraying caused about $50 \%$ reduction in egg-laying intensity. Egg hatching was only slightly reduced, and larvae and nymphs developed normally. HASSAN et al. (1991) rated bitertanol as harmless to all tested natural enemies, except $A$. andersoni, on which it had a slightly harmful effect. Bitertanol appear to be safe in integrated control programmes in Finnish conditions.

\subsubsection{Dichlofluanid}

In laboratory tests, $1000 \mathrm{ppm}$ dichlofluanid sprayed on larvae of $P$. ulmi either killed them or prevented their further development. However, it had no ef- 
fect on P. ulmi winter egg hatching (VI).

Dichlofluanid reduced numbers and prevented egg laying of P. ulmi. It also had some effect on $A$. schlechtendali. It had an adverse effect on phytoseiid mites (VI). KARG et al. (1973) showed that dichlofluanid is harmful to E. finlandicus. On the basis of field tests, HASSAN et al. (1991) rated dichlofluanid as moderately harmful to the phytoseiid mites A. andersoni and T. pyri. Although dichlofluanid has an effect on $P$. ulmi and $A$. schlechtendali, it should not be used in integrated control programmes. Treatments should be avoided especially if phytoseiid mites are present.

\subsubsection{Dithianon}

In laboratory tests, dithianon had only a slight, statistically nonsignificant effect on $P$. ulmi larvae and no influence on winter egg hatching (VI).

Four sprays with dithianon were harmless to the phytoseiid mites $P$. soleiger and A. subsolidus (VI). Dithianon had no effect on the predatory mites $T$. pyri and A. andersoni (VIGL 1986). SEIER (1989) studied the effect of $500 \mathrm{ppm}$ dithianon on the phytoseiid mites $A$. andersoni and $T$. pyri, and found only very low initial toxicity to $A$. andersoni females, and only a slight reduction in egg-laying intensity in both species. Egg hatching was not affected, and larvae and nymphs developed normally. With the exception of a slight harmful effect on A. andersoni, HASSAN et al. (1991) rated dithianon as harmless to natural enemies. In field tests, dithianon was harmless to E. finlandicus (VI). Dithianon appear to be safe in integrated control programmes in Finnish conditions.

\subsubsection{Triforine}

In laboratory tests, $240 \mathrm{ppm}$ triforine sprayed on larvae of $P$. ulmi either killed them or prevented their further development. Triforine caused $75 \%$ reduction in $P$. ulmi winter egg hatching when sprayed a few days before hatching. In a field experiment, four sprays with triforine in June-July temporarily reduced number of $A$. schlechtendali (VI).

Four sprays with triforine had a detrimental effect on numbers of phytoseiid mites, but, after the sprays, the phytoseiid mite numbers increased once more (VI). BoLLER et al. (1989) regarded triforine as harmless to $T$. pyri. In integrated control programmes, triforine could be sprayed in spring, but continuous use should be avoided.

\section{SUMMARY AND CONCLUSIONS}

Knowledge of naturally occurring phytoseiid mites in Finland was poor until the first survey conducted in 1985 to establish the occurrence of phytoseiid species on apple trees. Before that, only two species had been recorded in Finland. Numerous studies in many countries have proven that phytoseiid mites are the most important natural enemies of the European red spider mite Panonychus ulmi, the most harmful mite pest in Finnish apple orchards. The survey of phytoseiid mites showed that the same situation prevails in Finland, too.

Twelve species belonging to eight genera of the family Phytoseiidae were found to occur on apple trees. The most common species are Euseius finlandicus, Phytoseius macropilis and Paraseiulus soleiger. Of the other species, Amblyseius subsoli- dus and A. reductus occurred occasionally in relatively high densities, whereas Anthoseius rhenanus, A. suecicus, A. richteri, A. bakeri, A. viktorovi, Paraseiulus talbii and P. triporus occurred only occasionally and in low densities.

The mean density of phytoseiid mites on unsprayed trees was 1.2/leaf. In apple leaf samples from trees treated with pesticides, including at least one spray with organophosphorous insecticides, generally no or only a few phytoseiid mites were found. The most common species on sprayed apple trees were E. finlandicus, $P$. macropilis and $P$. soleiger, and their common densities in the treated trees were at most $0.2 /$ leaf. The mean density of $P$. ulmi was 15 times higher on sprayed apple trees than on unsprayed trees. 
Besides the species found on apple trees, eight other phytoseiid species were recorded on various other trees and bushes. Phytoseius juvenis, Seiulus aceri, Typhlodromus pyri, T. andrei, T. laurae, Proprioseiopsis okanagensis, Amblyseius zwoelferi and $A$. tenuis were reported as new species in Finland. $T$. pyri, which has been the subject of many investigations in integrated control programmes on apple, was found in only one location in Åland. This may be due to the low resistance to cold of this species.

Phytoseiid density exceeded $1 /$ leaf on several deciduous trees and bushes, e.g. Aesculus hippocastani, Corylus avellana, Fraxinus excelsior, Ribes nigrum, Rubus odoratus, Sorbus aucuparia, Tilia spp. and Ulmus glabra, found around apple orchards and in forest margins. On average, the highest densities of the phytoseiids $E$. finlandicus and $P$. macropilis were recorded on the hazel $C$. avellana. Other common trees and bushes inhabited by phytoseiids, although less abundantly, were Crataegus coccinea, Prunus padus and Salix caprea. E. finlandicus occurred most commonly and in the highest densities, followed by $P$. macropilis, $P$. soleiger, $P$. triporus and $A$. rhenanus. The predominant species in these plants also inhabit unsprayed apple trees.

The presence of prey mites, $P$. ulmi, the rust mite Aculus schlechtendali, or tydeid mites, was not a prerequisite for the occurrence of phytoseiid mites. Relatively high densities of E. finlandicus and $P$. macropilis were found even when no prey mites at all were present. The above species are known to reproduce well without mite prey, e.g. by feeding on pollen or fungal rhizomes and spores.

Experiments to control $P$. ulmi with specific acaricides were carried out in 1981-1989. An effective acaricide, flubenzimine, appeared to be harmful to the phytoseiids $E$. finlandicus and $P$. macropilis. Single treatments with clofentezine and hexythiazox, effective against $P$. ulmi, were harmless to E. finlandicus and $P$. macropilis, but repeated sprays of both acaricides reduced the density of phytoseiid mites.

The effect of fungicides on P. ulmi and on phytoseiid mites was also tested. Of the four fungicides used against the apple scab, dithianon and bitertanol were rated harmless to phytoseiid mites, whereas dichlofluanid was harmful to phytoseiids. Triforine sprays initially reduced numbers of phytoseiid mites, but later in the season the phytoseiid mites recovered and their density increased. Dichlofluanid also affected $P$. ulmi, and triforine appeared to inhibit egg hatching in P. ulmi.

The role of phytoseiid mites as natural enemies of $P$. ulmi in Finnish commercial apple orchards depends very much on the methods used to control insect pests. The use of less harmful pesticides and lower application dosages together with careful monitoring of the need for control would create better conditions for naturally occurring phytoseiid mites to survive and colonize apple trees. Phytoseiid mite populations can be promoted by planting their favoured host plants around orchards and as windbreak hedges between blocks. Care is needed to avoid destroying phytoseiids by spraying during windy weather. Once established phytoseiid mites are generally capable of keeping phytophagous mite populations under the economic threshold. Many other natural enemies such as anthocorid bugs are also effective predators of spider mites, and should likewise be protected.

Continuously high density of $P$. ulmi in an apple orchard is a signal that ecological damage has occurred, most likely due to intensive use of harmful pesticides. Recent findings from experimental orchards show that it takes 1-3 years to correct the situation, depending on the natural conditions around the orchard, if the use of harmful pesticides is discontinued.

\section{REFERENCES}

Amano, H. \& Chant, D.A. 1990. Species diversity and seasonal dynamics of Acari on abandoned apple trees in southern Ontario, Canada. Exp. Appl. Acarol. 8: 71-96.

Blomevist, H., Hirvonen, L., Hynninen, E.-L. \& Vanhanen,
R. 1992. Torjunta-aineet 1992. [Pesticides 1992]. Maatilahallitus, Helsinki. 64 p.

Boller, E.F., Remund, U. \& Candolf, M.P. 1988. Hedges as potential sources of Typhlodromus pyri, the most im- 
portant predatory mite in vineyards of northern Switzerland. Entomophaga 33: 249-255.

—, Bigler, F., Bieri, M., Häni, F. \& Stäubli, A. 1989. Nebenwirkungen von Pestiziden auf die Nützlingsfauna wirtscaftlichen Kulturen. Schweiz. Landw. Fo. 28: 3-40.

— \& Remund, U. 1991. Grossflachige Ansiedlungsaktion mit der Raubmilbe Typhlodromus pyri. Schweiz. Z. Obst. Weinbau. 127, 10: 280-283.

BOwER, C.C. 1990. Comparison of clofentezine and hexythiazox with cyhexatin for integrated control of European red mite, Panonychus ulmi (Koch). Crop Protect. 9: 463468.

Bryan, K.M.G., Geering, Q.A. \& ReId, J. 1981. NC21314, a novel compound for control of phytophagous mites. Proc. Brit. Crop Protect. Conf. Pests and Diseases 1981: $67-74$.

CAlis, J.N.M., Overmeer, W.P.J. \& van der Geest, L.P.S. 1988. Tydeids as alternative prey for phytoseiid mites in apple orchards. Med. Fac. Landbouww. Rijksuniv. Gent 53: 793-798.

Chant, D.A. 1959. Phytoseiid mites (Acarina: Phytoseiidae). Part I. Bionomics of seven species in South-eastem England. Can. Entomol. 91, Suppl. 12: 5-44.

— \& Yoshida-Shaul, E. 1991. Adult ventral setal patterns in the family Phytoseiidae (Acari: Gamasina). Int. J. Acarol. 17: 187-199.

Chazeau, J. 1985. Predaceous insects. In: Helle, W. \& Sabelis, M.W. (eds.). Spider mites. Their Biology, Natural Enemies, and Control. Elsevier, Amsterdam. Vol. B. p. 211-246.

Collyer, E. 1956. Notes on the biology of some predacious mites on fruit trees in South-Eastern England. Bull. Entomol. Res. 47: 205214.

- 1964. A summary of experiments to demonstrate the role of Typhlodromus pyri Scheut. in the control of Panonychus ulmi (Koch) in England. Acarologia. Proc. First Int. Congr. Acarol., Fort Collins, Colorado, USA, 1963: 363371.

Cranham, J.E. 1979. Managing spider mites on fruit trees. Span 22: 28-30.

- 1982. Resistance to organophosphates, and genetic background, in fruit tree red spider mite, Panonychus ulmi, from English apple orchards. Ann. Appl. Biol. 100: 1123.

-, Kapetanakis, E.G. \& Fisher, A.J. 1983. Resistance to insecticides in the predatory mite Typhlodromus pyri and its spider mite prey. Proc. 10th Int. Congr. Plant Prot., Vol. 2: 638.

— \& Helle, W. 1985. Pesticide resistance in Tetranychidae. In: Helle, W. \& Sabelis, M.W. (eds.). Spider mites. Their biology, natural enemies and control. Elsevier, Amsterdam. Vol B. p. 405-421.

Croft, B.A. 1975. Integrated control of apple mites. Bull. E825 Mich. State Coop. Ext. Ser. 12 p.

- \& Barnes, M.M. 1971. Comparative studies on four strains of Typhlodromus occidentalis. III. Evaluations of releases of insecticide resistant strains into an apple orchard ecosystem. J. Econ. Entomol. 64: 845- 850.

— \& MEYER, R.H. 1973. Carbamate and organophosphorus resistance patterns in populations of Amblyseius fallacis. Environ. Entomol. 2: 691-695.

— \& Brown, A.W.A. 1975. Responses of arthropod natural enemies to insecticides. Ann. Rev. Entomol. 20: 285335.

— \& STRICKLER, K. 1983. Natural enemy resistance to pesticides: Documentation, characterization, theory and application. In: Georghieu, G.P. \& Saito, T. (eds.). Pest resistance to pesticides. Plenum press, New York. p. 669-702.

—, Hoyt, S.C. \& Westigard, P.H. 1987. Spider mite management on pome fruits, revisited: organotin and acaricide resistance management. J. Econ. Entomol. 80: 304 311.

—, Shearer, P., Fields, G.J. \& Riedl, H.W. 1990. Distribution of Metaseiulus occidentalis (Nesbitt) and Typhlodromus pyri Scheuten (Parasitiformes: Phytoseiidae) in apple orchards of the Hood River Valley, Oregon. Can. Entomol. 122: 5-14.

—, MacRae, I.V. \& Currans, K.G. 1992. Factors affecting biological control of apple mites by mixed populations of Metaseiulus occidentalis and Typhlodromus pyri. Exp. Appl. Acarol. 14: 343-355.

Dennehy, T.J., Nyrop, J.P., Reissig, W.H. \& Weires, R.W. 1988. Characterization of resistance to dicofol in spider mites (Acari: Tetranychidae) from New York apple orchards. J. Econ. Entomol. 81: 551-1561.

Dickler, E. \& SChÄFERMEYER, S. (eds.). 1991. General principles, guidelines and standards for integrated production of pome fruits in Europe. Procedures for endorsement of national or regional guidelines and standards: a provisional working document. IOBC/WPRS Bull. 1991/XIV/3, 67 p.

Dosse, G. 1956. Über die Entwicklung einiger Raubmilben bei verschiedenen Nahrungstieren (Acar., Phytoseiidae). Pflanzenschutzberichte 16: 122-136.

- 1960. Über den Einfluss der Raubmilbe Typhlodromus tiliae Oud. auf die Obstbaumspinnmilbe Metatetranychus ulmi Koch (Acari). Pflanzenschutzberichte 24: 113137.

Duso, C. 1992. Biological control of tetranychid mites in peach orchards of northern Italy: role of Amblyseius andersoni (Chant) and Amblyseius finlandicus (Oud.) (Acari: Phytoseiidae). Acta Phytopathol. Entomol. Hungarica 27: 211-217.

EASterbroOK, M.A. 1984. Chemical and integrated control of apple rust mite. Proc. Brit. Plant Prot. Conf., Pests and Diseases. Brighton, England. Vol. 3: 1107-1111.

— \& Fuller, Morwenna M. 1986. Russeting of apples caused by apple rust mite Aculus schlechtendali (Acarina: Eriophyidae). Ann. appl. Biol. 109: 1-9.

EDLAND, T. 1986. Rovmidd i frukthagar. [Predatory mites in orchards.] Nordiskt Plantevernkonferanse 1986. Aktuelt fra statens fagtjeneste for landbruket Nr. 8, 1986: 207211.

- 1987. Rovmiddar (Phytoseiidae) på frilandsvekstar i Norge. (Summary: Predacious mites (Phytoseiidae) on field-grown plants in Norway.) Entomol. Tidskr. 108: 21-22. 
Fauvel, G. \& Gendrier, J.P. 1992. Problems met in establishment of phytoseiids in apple orchards of southeastern France. Acta Phytopathol. Entomol. Hungarica 27: 223232.

Fischer-ColbriE, P. \& El-Borolossy, M. 1988. Nebenwirkungen von Winter- und Austriebbehandlungen auf Raubmilbenpopulationen in Apfelbäumen. Pflanzenschutzberichte 49: 125131.

— \& El-Borolossy, M. 1989. Untersuchungen zur Bedeutung einzelner bodendeckender Pflanzen als Raubmilbenreservoir für Obstkulturen. Pflanzenschutzberichte 50: 34-37.

Freier, B. GotTwald, R. \& Burth, U. 1992. New principles of monitoring and decision-making within IPM in apple orchards of the GDR. Acta Phytopathol. Entomol. Hungarica 27: 245-249.

GenINI, M. \& BAllLoD, M. 1987. Introduction de souches resistantes de Typhlodromus pyri (Scheuten) et Amblyseius andersoni Chant (Acari: Phytoseiidae) en vergers de pommiers. (Summary: The introduction of resistant strains of Typhlodromus pyri (Scheuten) and Amblyseius andersoni Chant (Acari: Phytoseiidae) in apple orchards.) Rev. Suisse Viticult. d'Arboricult. d'Horticult. 19: 115-123.

Gerson, U. 1985. Other predaceous mites and spiders. In: Helle, W. \& Sabelis, M.W. (eds.). Spider mites. Their Biology, Natural Enemies, and Control. Elsevier, Amsterdam. Vol. B. p. 205-210.

GruYs, P. 1975. Development and implementation of an integrated control programme for apple orchards in the Netherlands. Proc. 8th British Insecticide and Fungicide Conf. 3: 823-835.

- 1982. Hits and misses: the ecological approach to pest control in orchards. Entomol. Exp. Appl. 31: 70-87.

Hadam, J.J, Aliniazee, M.T. \& Croft, B.A. 1986. Phytoseiid mites (Parasitiformes: Phytoseiidae) of major crops in Willamette Valley, Oregon, and pesticide resistance in Typhlodromus pyri Scheuten. Environ. Entomol. 15: 1255-1263.

HANSEN, E.W. \& Johnsen, S. 1986. Rovmider av familien Phytoseiidae i Danmark (Acarina, Gamasina). (Summary: Predacious mites in the family Phytoseiidae in Denmark (Acarina, Gamasina).) Entomol. Meddel. 53: 137-142.

Hardman, J.M. 1992. Apple pest management in north America: challenge and response. Proc. Brighton Crop. Prot. Conf. 1992. Brighton, England. Vol. 2: 507-516.

Hassan, S.A., Bigler, F., Bogenschotz, H. Boller, E., Brun, J., Calis, J.N.M., Chiverton, P., CoremansPelseneer, J., Duso, C., Lewis, G.B., Mansour, F., Moreth, L. Oomen, P.A., Overmeer, W.P.J., Polgar, L., Rieckman, W., Samsøe-Petersen, L., Stäubli, A., Sterk, G., Tavares, K., Tuset, J.J. \& Viggiani, G. 1991. Results of the fifth joint pesticide testing programme carried out by the IOBC/WPRS-working group "Pesticides and Beneficial Organisms". Entomophaga 36: 55-67.

HeikinheImo, O. 1956. Kehrääjäpunkeista ja niiden torjunnasta uusimpien tutkimusten valossa. (Referat: Über Spinnmilben und ihre Bekämpfung im Lichte der neuesten Untersuchungen). Maatal. ja Koetoim. 10: 150-161.

Hele, W. \& van de VRIE, M. 1974. Problems with spider mites. Outlook Agric. 8: 119-125.

— \& Sabel.s, M.W. (eds.). 1985. Spider mites. Their Biology, Natural Enemies, and Control. Vol. B. Elsevier, Amsterdam. 458 p.

HERBERT, H.J. 1959. Note on feeding ranges of six species of predaceous mites (Acarina: Phytoseiidae) in the laboratory. Can. Entomol. 91: 812.

HesJedAl, K. 1990. Integrated fruit production in Norway. Acta Horticult. 285: 47-53.

Hoy, M. 1982. Aerial dispersion and field efficacy of a genetically improved strain of the spider-mite predator Metaseiulus occidentalis. Entomol. Exp. Appl. 32: 205212.

-, Groot, R. \& van de BAAN, H.E. 1985. Influence of aerial dispersal on persistence and spread of pesticide-resistant Metaseiulus occidentalis in California almond orchards. Entomol. Exp. Appl. 37: 17-31.

Hort, S.C. 1972. Resistance to azinphosmethyl of Typhlodromus pyri (Acarina: Phytoseiidae) from New Zealand. N. Z. J. Science 15: 16-21.

Ioriatt, C., Pellizzari, G. \& Sacco, M. 1983. Prime esperienze sul controllo biologico di Panonychus ulmi Koch con acari fitoseidi in Trentino. (Summary: First experiments on the biological control of Panonychus ulmi Koch with phytoseiid mites in the Trento district.) Redia 66: 295-310.

Ivancich Gambaro, P. 1986. Diapause in Amblyseius andersoni Chant (=A. potentillae Garman) (Acarina Phytoseiidae) in the climate of the Po Valley. Boll. Zool. agr. Bachic. Ser. II 22: 31-41.

- 1988. Natural alternative food for Amblyseius andersoni Chant (Acarina: Phytoseiidae) on plants without prey. Long-term research in orchards with a prey-predator equilibrium. Redia 71: 161-171.

Jenser, G., BALÁzs, K. \& RÁcZ, V. 1992. Important beneficial insects and mites in Hungarian orchards. Acta Phytopath. Entomol. Hungarica 27: 321-327.

KANERvo, V. 1960. Gegenwärtige Hauptprobleme der landwirtschaftlichen Schädlingsforschung in Finnland. Anz. Schädlingskunde 33: 1-5.

— 1961. Einfluss der Bekämpfungsmassnahmen im Apfelbau auf die Populationsentwicklung der Obstbaumspinnmilbe (Metatetranychus pilosus C. \& F.) und ihre natürlichen Feinde in Finnland. XI Int. Kongr. Entomol., Wien 1960, Bd. II: 64-72.

— 1967. Augenblicklicher Stand der integrierten Bekämpfung im Obstbau in Finland. Entomophaga Mem. H.S. 3: 125-126.

KARG, W. 1972. Untersuchungen über die Korrelation zwischen dominierenden Raubmilbenarten und ihrer möglichen Beute in Apfelanlagen. Arch. Pflanzenschutz 8: 29-52.

- 1983. Systematische Untersuchungen der Gattungen der Raubmilbenfamilie Phytoseiidae Berlese 1916 mit der Beschreibung von 8 neuen Arten. Mitt. Zool. Mus. Berlin 59: 293-328. 
- 1992. The importance of so-called indifferent mite species for the equilibrium between spider mites and their antagonists. Acta Phytopathol. Entomol. Hungarica 27: 333-342.

—, Burth, U. \& Ramson, A. 1973. Der Einfluss von Fungiziden auf das Auftreten von Spinnmilben und anderen blattbewohnenden Milbengruppen in Apfelanlagen. Nachr.-BI. Pflanzenschutzd. DDR 27: 169-175.

— \& EdLAND, T. 1987. Neue Raubmilbenarten der Phytoseiidae Berlese, 1916. Deutsche ent. Z., N.F. 34: 387-395.

Kozlowski, J. \& Kozlowska, M. 1991. Notes on Aculus schlechtendali (Nal.) as food for predatory mites. In: Dusbábek, F. \& Bukva, V. (eds.). 1991. Modem Acarology. Academia, Prague and SPB Academic Publishing bv, The Hague, Vol. 2, p. 675-678.

KNISLEY, C.B. \& SwIFT, P.C. 1972. Qualitative study of mite fauna associated with apple foliage in New Jersey. J. Econ. Entomol. 65: 445-448.

Kropczynska, D. \& Tuovinen, T. 1987. Predatory mites (Acarina: Phytoseiidae) on apple-trees in Finland. Entomol. Tidskr. 108: 31-32.

— \& Tuovinen, T. 1988. Occurrence of phytoseiid mites (Acari: Phytoseiidae) on apple trees in Finland. Ann. Agric. Fenn. 27: 305314.

KropCZYNSKA-LiNKIEWICZ, D. 1973. Studies on feeding of four species of phytoseiid mites (Acarina: Phytoseiidae). Proc. 3rd Int. Congr. Acarol., Prague, 1971: 225-227.

KUIJPERS, L.A.M. 1992. A review of the selectivity of Dimilin in orchards. Acta Phytopathologica et Entomologica Hungarica 27: 375384 .

Lienk, S.E, Watve, C. \& Weires, R.W. 1980. Phytophagous and predacious mites on apple in New York. Search Agric. 6, 14 p.

Listo, J., Listo, E.-M. \& Kanervo, V. 1939. Tutkimuksia hedelmäpuupunkista. (Summary: Studies of the fruit tree red mite (Paratetranychus pilosus C. \& F.)). Valt. Maatalouskoet. Julk. 99: 1-143.

MacPheE, A.W. 1963. The effect of low temperatures on some predaceous phytoseiid mites, and on the brown mite Bryobia arborea M. \& A. Can. Entomol. 95: 41-44.

MarkKula, M. \& KurpPA, S. 1985. Resistance of insects and mites to pesticides in Finland. Ann. Agric. Fenn. 24: 161-174.

Marshall, D.B. \& Pree, D.J. 1991. Effects of miticides on the life stages of European red mite, Panonychus ulmi (Koch)(Acari: Tetranychidae). Can. Entomol. 123: 77 87.

McMurtry, J.A. 1992. Dynamics and potential impact of 'generalist' phytoseiids in agroecosystems and possibilities for establishment of exotic species. Exp. Appl. Acarol. 14: 371-382.

—, Huffaker, B.C. \& van de VRIE, M. 1970. Ecology of tetranychid mites and their natural enemies: a review. I. Tetranychid enemies: their biological characters and the impact of spray practices. Hilgardia 40: 331-390.

_ \& van de VRIE, M. 1973. Predation by Amblyseius potentillae (Garman) on Panonychus ulmi (Koch) in simple ecosystems Acarina: Phytoseiidae, Tetranychidae). Hilgardia 42: 17-34.
Minks, A.K., Woets, J. \& Trapman, M. 1988. Limitations to the introduction of IPM into apple orchards in the Netherlands. Proc. XVIII Int. Congr. Entomol., Vancouver, B.C. Canada, July 3 to $9,1988: 322$.

Moraes, G.I. de, McMurtry, J.A. \& Denmark, H.A. 1986. A catalog of the mite family Phytoseiidae: references to taxonomy, synonymy, distribution and habitat. EMBRAPA-Departamento de Difusao de tecnologia, Brasilia DF. 353 p.

OVERMEER, W.P.J. 1985. Alternative prey and other food resources. In: Helle, W. \& Sabelis, M.W. (eds.). Spider mites. Their Biology, Natural Enemies, and Control. Elsevier, Amsterdam. Vol. B. p. 131- 139.

— \& van ZoN, A.Q. 1983. Resistance to parathion in the predacious mite Typhlodromus pyri Scheuten (Acarina: Phytoseiidae). Meded. Fac. Landbouwwet. Rijksuniv. Gent 43: 247-251.

Pickett, A.D., Putnam, W.L. \& Le Roux, E.J. 1958. Progress in harmonizing biological and chemical control of orchard pests in eastern Canada. Proc. 10th Congr. Entomol., Montreal, 3: 169-174.

Post, A. 1962. Effect of cultural measures on the population density of the fruit tree red spider mite, Panonychus ulmi Koch (Acari: Tetranychidae). Tijdschrift over Planteziekten 69: 1-110.

Pree, D.J. \& W AGner, H.W. 1987. Occurrence of cyhexatin and dicofol resistance in the European red mite, Panonychus ulmi (Koch) (Acari: Tetranychidae), in southem Ontario. Can. Entomol. 119: 287-290.

—, Marshall, D.B. \& McGarvey, B.D. 1992. Residual toxicity of dicofol, formetanate $\mathrm{HCl}$, propargite, hexythiazox, and clofentezine to European red mite on peach. Can. Entomol. 124: 59-67.

RABBINGE, R. 1976. Biological control of fruit-tree red spider mite. Centre for Agricultural Publishing and Documentation, Wageningen. $228 \mathrm{p}$.

- 1985. Aspects of damage assessment. In: Helle, W. \& Sabelis, M.W. (eds.). Spider mites. Their Biology, Natural Enemies, and Control. Elsevier, Amsterdam. Vol. B. p. 261-272.

ReIssig, W.H. \& HuL., L.A. 1991. Hexythiazox resistance in a field population of European red mite on apples. J. Econ. Entomol. 84: 727-735.

Riedl, H., Barnett, W.W., Beers, E., Brunner, J.F., Burts, E., Croft, A., Shearer, P.W. \& Westigard, P.H. 1992. Current status, monitoring and management of insecticide and miticide resistance on deciduous tree fruits in the western United States. Acta Phytopathol. Entomol. Hungarica 27: 535-544.

SCHAuSBERger, P. 1990. Vergleichende Untersuchungen zur Biologie von Amblyseius aberrans Oudemans und Amblyseius finlandicus Oudemans (Gamasida: Phytoseiidae). Diss. Formal und Naturwissenschaftlichen Fakultät der Universität Wien. 102 p.

SCHLIESSKE, J. 1989. Zur Notwendigkeit der Bekämpfung von Milben an Baumschulgehölzen. Deutsche Baumschule 41: 128-130.

Sechser, B., Thueler, P. \& Bachmann, A. 1984. Observations on population levels of the European red mite 
(Acarina: Tetranychidae) and associated arthropod predator complexes in different spray programs over a 5-year period. Environ. Entomol. 13: 1577-1582.

SEIER, H. 1989. Erfassung und Populationsverlauf der Spinnmilben und ihre natürlichen feinde sowie Untersuchungen über die Freilassung von Raubmilben im Apfelanbaugebiet Meckenheim. Diss. Institut fur Pflanzenkrankheiten der Rheinischen Friedrich-WilhelmsUniversität zu Bonn. 93 p.

SEllniCK, M. 1958. Untersuchungen über die "Bollnäser Krankheit" I. Milben aus landwirtschaftlichen Betrieben Nordschwedens. Stat. Växtskyddanst. Medd. 11: 9-60.

Solmøy, T., Dybwad, E., Hesjedal, K., Hossain, M. \& Hovland, B. 1991. Observations on Aculus schlechtendali (Nal.) (Acari: Eriophyidae) in apple orchards in Western Norway. In: Dusbábek, F. \& Bukva, V. (eds.). Modern Acarology. Academia, Prague and SPB Academic Publishing bv, The Hague, Vol. 1, p. 523-532.

Solomon, M.G. 1986. Natural control of red spider mite in English apple orchards. IOBC/WPRS Bull. IX/3: 43-47.

- 1988. Managing predators in apple orchards in the UK. Proc. XVIII Int. Congr. Entomol., Vancouver, B.C. Canada, July 3 to $9,1988: 322$.

— \& EAsterbrook, M.A. 1983. OP-resistant Typhlodromus pyri for apple orchard mite management. Proc. 10th Int. Congr. Plant Prot. Vol. 3: 999.

— \& Fitzgerald, J.D. 1984. The role of resistant Typhlodromus pyri in apple orchards. Proc. Brit. Plant Prot. Conf., Pests and Diseases, Brighton, England. Vol. 3: 1113-1116.

Strickler, K. \& Croft, B.A. 1982. Selection of permethrin resistance in the predatory mite Amblyseius fallacis Garman (Acarina: Phytoseiidae). Entomol. Exp. Appl. 31: 339-345.

Śula, J. \& Zacharda, M. 1991. Differential potentials of three predatory mites (Acari: Phytoseiidae) to develop resistance to azinphos-ethyl. In: Dusbábek, F. \& Bukva, V. (eds.). Modern Acarology. Academia, Prague and SPB Academic Publishing bv, The Hague, Vol. 2, p. 425 430.

Thistlewood, H.M.A. 1991. A survey of predatory mites in Ontario apple orchards with diverse pesticide programs. Can. Entomol. 123: 1163- 1174.

Thwarte, W.G. 1991. Resistance to clofentezine and hexythiazox in Panonychus ulmi from apples in Australia. Exp. Appl. Acarol. 11: 73-80.

Tokunova, M.V. \& Malov, N.A. 1988. [Biological methods of pest control on strawberry.] (In Russian). Zashchita Rastenii, 1988 (5): 37-38.

TORNEUS, C. 1990. Bedömning av bekämpningsbehov mot äppelbladkvalster, Aculus schlechtendali. [Assessing of spraying threshold against the apple rust mite, Aculus schlechtendali]. Miljövänlig produktion af frugt, bär og grönsaker, Seminar nr. 174. NJFUtredning/Rapport nr. 66: 12-15.

Trapman, M. 1989. Integrierte Bekämpfung von Roter Spinne und Rostmilben im Obstbau - holländische Er- fahrungen. Besseres-Obst. 34: 1, 8-10.

TUOVINEN, T. 1992a. Effect of weather on the abundance of winter eggs of European red spider mite on apple. Agric. Sci. Finl. 1: 83-94.

- 1992b. Phytoseiid mites on cultivated berries in Finland. The second Symposium of European Association of Acarologists, August 31- September 5, 1992, Krynica, Poland. Abstracts: 82.

VAPPULA, N. 1965. Pests of cultivated plants in Finland. Ann. Agric. Fenn. Vol. 1. Suppl. 1. 239 p.

VIGL, J. 1986. Nebenwirkungen einiger Schorfmittel auf Raub und Spinnmilben. Obstbau-Weinbau 23: 98-101.

-, Boscheri, S. \& Mantinger, H. 1985. Einfluss verschiedener Insektizide und Akarizide auf Raubmilben. Obstbau-Weinbau 22: 108-112.

VoGT, H. 1992. Acaricide tests in apple orchards with special regard to their effects on beneficials and on the apple rust mite. Acta Phytopathol. Entomol. Hungarica 27: 659667.

-, Dickler, E. \& Grauhan, H. 1990. Einfluss der einmaligen Anwendung von Akariziden auf die Populationsdynamik von Panonychus ulmi (Acari, Tetranychidae) und Aculus schlechtendali (Acari, Eriophyoidea) am Apfel unter besonderer Berücksichtigung der Antagonisten. J. Appl. Entomol. 110: 35-54.

Van de VRIE, M. 1972. Phytoseiid mites on tree crops, ornamental and wild plants in the Netherlands. Entomol. Berichten 32: 1319.

- 1985. Control of Tetranychidae in crops. Apple. In: Helle, W. \& Sabelis, M.W. (eds.). Spider mites. Their Biology, Natural Enemies, and Control. Elsevier, Amsterdam. Vol. B. p. 311-325.

Walde, S.J., Nyrop, J.P. \& Hardman, J.M. 1992. Dynamics of Panonychus ulmi and Typhlodromus pyri: factors contributing to persistence. Exp. Appl. Acarol. 14: 261-291.

WEARING, C.H. 1982. Integrated pest management - progress and prospects, with special reference to horticulture. N. Z. J. Exp. Agric. 10: 87-94.

-, Walker, J.T.S., Collyer, E. \& Thomas, W.P. 1978. Integrated control of apple pests in New Zealand 8. Commercial assessment of an integrated control programme against European red mite using an insecticide-resistant predator. N. Z. J. Zool. 5: 823-837.

Welty, C., Reissig, W.H., Dennehy, T.J. \& Weires, R.W. 1988. Susceptibilty to hexythiazox of eggs and larvae of European red mite (Acari: Tetranychidae). J. Econ. Entomol. 81: 586-592.

WiLDBoLz, T. 1979. The status of integrated control in orchards. Proc. 1979 British Crop prot. Conf. - Pests and Diseases 3: 623631 .

- 1988. Integrated pest management in Swiss apple orchards: Stability and risks. Entomol. Exp. Appl. 49: 71-74.

- 1992. Pest situations in orchards evolving: natural and man made factors. Acta Phytopathol. Entomol. Hungarica 27: 669-678.

— \& Staub, A. 1986. Raubmilbenansiedlung im Obstbau. Schweiz. Z. Obst. Weinbau. 122: 483-488. 


\title{
Phytoseiidae-heimon (Acari: Gamasina) petopunkit omenaviljelmillä ja niiden merkitys tuholaisina esiintyvien punkkien integroidussa torjunnassa
}

\author{
TUOMO TUOVINEN
}

Maatalouden tutkimuskeskus

Petopunkit tulivat Suomessa yleisesti tunnetuiksi vihannespunkin biologisen torjunnan yhteydessä 1970-luvulla. Kuitenkin jo 1930-luvulla tehtiin havaintoja petopunkkien esiintymisestä omenapuulla, ja jo silloin todettiin, että petopunkeilla voi olla huomattava merkitys hedelmäpuupunkin luontaisina vihollisina.

\section{Petopunkkilajit Suomessa ja niiden esiintyminen}

Tämän tutkimuksen yhteydessä määritettiin yhteensä 20 petopunkkilajia, joista 12 esiintyi myös omenalla. Kaksi lajia, Euseius finlandicus ja Phytoseius macropilis, olivat yleisiä ja käsittivät yli $70 \%$ kaikista omenapuulla esiintyvistä petopunkeista. Samat lajit esiintyivät runsaslukuisina ja laajasti levinneinä myös monilla muilla lehtipuilla ja pensailla. Muista omenalla esiintyvistä lajeista Paraseiulus soleiger oli yleinen ja paikoin runsaslukuinen, Amblyseius subsolidus ja A. reductus esiintyivät huomattavasti harvemmin, mutta kuitenkin eräillä alueilla kohtalaisen runsaslukuisina. Muut omenalla havaitut lajit, Anthoseius rhenanus, A. suecicus, A. richteri, A. bakeri, A. viktorovi, Paraseiulus talbii ja $P$. triporus olivat harvinaisia.

Muilta kasveilta otetuissa näytteissä $E$. finlandicus ja $P$. macropilis olivat runsaslukuisimpia. Näytteitä kerättiin yhteensä 47 kasvilajilta, joilla esiintyi omenalla todettujen lajien lisäksi 8 muuta petopunkkilajia: Phytoseius juvenis, Seiulus aceri, Typhlodromus andrei, T. laurae, T. pyri, Proprioseiopsis okanagensis, Amblyseius tenuis ja A. zwoelferi. Useimmat näistä lajeista olivat harvinaisia. Petopunkkeja esiintyi säännöllisesti ja runsaasti mm. hevoskastanjalla, jalavalla, lehmuksella, pihlajalla, raidalla, saarnella, tuomella sekä pensaista $\mathrm{mm}$. pähkinäpensaalla, orapihlajalla sekä Ribes- ja Rubus-lajeilla.

Omenatarhan lähiympäristön kasvullisuuden havaittiin vaikuttavan petopunkkien runsauteen omenapuilla. Eräässä havaintotarhassa todettiin petopunkkien määrän kasvavan huomattaviksi pian haitallisten ruiskutusten jälkeen. Tarhan välittömässä läheisyydessä kasvoi mm. kookkaita lehmuksia ja tammia sekä pähkinäpensaita, joilla esiintyi runsaasti etenkin E. finlandicus -petopunkkia. Punkkien pääteltiin kulkeutuvan helposti tuulen mukana ympäröivistä puista ja pensaista omenapuille. Hedelmäpuupunkin luontaista torjuntaa voidaankin edistää suojelemalla hyviä petopunkkien isäntäkasveja ja istuttamalla näitä myös tuulensuojiksi. Ruiskutettaessa on varottava torjunta-aineen kulkeutumista näihin kasvustoihin.

\section{Torjunta-aineet ja petopunkit}

Hyönteisten torjunta-aineilla ruiskuttamattomissa omenapuissa esiintyi elokuussa yhtä lehteä kohti keskimäärin 1,2 petopunkkia ja tavanomaisesti ruiskutetuissa puissa vain 0,05 petopunkkia. Hedelmäpuupunkkien osalta tilanne oli täysin päinvastainen: ruiskuttamattomissa tarhoissa määrä oli keskimäärin 1 punkki lehteä kohti ja ruiskutetuissa tarhoissa 15kertainen. Ruiskutetuissa tarhoissa hedelmäpuupunkkien määrä oli huomattava vaikka tarhoissa oli suoritettu myös punkkien torjuntakäsittelyjä.

Hedelmäpuupunkki lisääntyy etenkin lämpiminä ja kuivina kesinä nopeasti ja voi alentaa huomattavasti omenasatoa. Hedelmäpuupunkin torjunta on viime vuosina perustunut pääasiassa kinometionaatin käyttöön, mutta toivottua tehoa ei läheskään aina saavuteta. Myös omenankellastajapunkki on viime vuosina paikoin yleistynyt. Lähes kaikki omenaviljelmillä käytettävät hyönteisten torjunta-aineet ovat haitallisia myös punkkien luontaisille vihollisille, petoluteille ja petopunkeille.

Jatkuvasti suuri hedelmäpuupunkkien määrä omenatarhasssa on osoitus siitä, että tarhassa vallitsee ekologisesti epävakaa tilanne, mikä lähes aina johtuu torjunta-aineiden runsaasta käytöstä. Koetarhoissa saatujen kokemusten mukaan tilanne voidaan saada hallintaan 1-3 vuodessa, mikäli petopunkeille ja muille luontaisille vihollisille haitallisia ruiskutuksia voidaan vähentää ratkaisevasti.

Tämän tutkimuksen yhteydessä testatut akarisidit, flubentsimiini, hexythiazox ('heksitiatsoksi') ja klofentetsiini tehosivat hyvin hedelmäpuupunkkiin. Flubentsimiini tehosi myös omenankellastajapunkkiin. Flubentsimiini oli kuitenkin haitallinen petopunkeille, sen sijaan klofentetsiini ja hexythiazox olivat lähes haitattomia ja siten käyttökelpoisia myös integroidussa torjunnassa.

Omenaruven torjunta-aineista diklofluanidilla ja triforiinilla oli sivuvaikutus hedelmäpuupunkkiin ja omenankellastajapunkkiin, mutta molemmat vaikuttivat haitallisesti myös petopunkkeihin. Bitertanoli ja ditianoni olivat haitattomia petopunkeille.

\section{Kohti luontaista punkkien torjuntaa}

Tämän tutkimuksen yhteydessä saatujen kokemusten perusteella voidaan suositella seuraavia toimenpiteitä, jotka soveltuvat omenan integroidun tuotannon yhteyteen:

1) Käytetään kasvintuhoojien ja luontaisten vihollisten havainnointi- ja arviointimenetelmiä torjunta-aineiden käytön 
tarpeen selvittämiseksi.

2) Sovelletaan ohjekynnysarvoja ottaen huomioon luontaisten vihollisten esiintyminen ja tarhan erityisolosuhteet.

3) Huolehditaan viljelyhygieniasta ja käytetään viljelyteknisiä tai biologisia torjuntamenetelmiä silloin kun se on mahdolllista.

4) Valitaan haitattomin mutta samalla riittävän tehokas torjunta-aine, käytetään alinta riittävän tehokasta liuosväkevyyttä ja nestemäärää ja kohdistetaan ruiskutus havaintoihin perustuen oikeaan ajankohtaan.

5) Vältetään petopunkeille haitallisten torjunta-aineiden käyttöä erityisesti ennen kukintaa, talvehtineiden petopunkkien lisääntymisen varmistamiseksi.

6) Varotaan torjunta-aineen ajautumista tuulen mukana lähiympäristön lehtipuihin ja pensaisiin.

7) Arvioidaan omenaruven torjunnan tarve varoituslaitteen avulla tai sään seurannan mukaan. Käytetään torjuntaan mieluummin bitertanolia tai ditianonia kuin diklofluanidia tai triforiinia.

8) Säilytetään lähiympäristön kookkaat lehtipuut, kuten hevoskastanjat, lehmukset ja jalavat. Istutetaan tuulensuojiin pähkinäpensasta, raitaa ja muita petopunkkien suosimia puita ja pensaita.

9) Perustetaan erityinen petopunkkien kasvatusalue istuttamalla omenapuun taimia tihäksi kasvustoksi alueelle, jota ei käsitellä torjunta-aineilla. Siirretään kasvatustarhaan petopunkkeja, joiden annetaan lisääntyä häiritsemättä. Kasvatusalueelta voidaan petopunkkeja levitttää vuosiversojen mukana omenatarhaan heinä-elokuussa, erityisesti mahdollisten petopunkeille haitallisten ruiskutusten jälkeen.

10) Jos hedelmäpuupunkkien määrä on suuri, käytetään tehokasta valmistetta niiden määrän alentamiseksi ennen pe- topunkkien siirtämistä tarhaan. Fenbutatinaoksidi-, klofentetsiini- tai hexythiazox-valmisteiden haitallisuus petopunkeille on käytännössä vähäinen.

\section{Petopunkkien hyväksikäytön mahdollisuudet avomaaviljelyksillä}

Omenan lisäksi monet muut monivuotiset avomaaviljelykset kärsivät punkkien vioituksista. Petopunkkeja koskevaa tutkimusta kannattaa tulevaisuudessa kohdistaa erityisesti marjakasveilla esiintyvien haitallisten ja kemiallisesti vaikeasti torjuttavien punkkien kuten mansikkapunkin ja herukan äkämäpunkin luontaisen ja biologisen torjunnan kehittämiseksi. Tämän tutkimuksen yhteydessä kertynyttä tietoa petopunkkien esiintymisestä eri kasveilla voidaan hyödyntää myös marjakasvien kasvinsuojelua koskevissa tutkimuksissa.

Mikäli meillä esiintyvien petopunkkien kestävyttää hyönteisten torjunta-aineita vastaan voidaan parantaa, avautuu petopunkkien hyväksikäytölle vielä paremmat mahdollisuudet. Toisaalta voidaan harkita resistenttien petopunkkikantojen tuontia maahan. Tällainen laji voisi olla $T$. pyri, jota yleisesti on käytetty Keski-Euroopassa. Myös uuden lajin tuontia voidaan harkita, joskin epäonnistuminen on tällöin paljon todennäköisempää.

Petopunkkilajeista tunnetaan todennäköisesti vasta vain pieni osa, ja vain harvoista lajeista on olemassa perusteellista biologista tietoa. Meillä luonnossa esiintyvien lajien massakasvatus viljelyksille levittämistä varten voi myös tulla ajankohtaiseksi. Kasvatusmenetelmiä, jotka soveltuvat petopunkkien avomaalle levittämistä varten ei ole vielä riittävästi tutkittu. Myös tilakohtaisten petopunkkiviljelysten mahdollisuudet tulisi selvittää. 
${ }^{\circ}$ Entomologica Fennica. 31.V.1993

\title{
Identification and occurrence of phytoseiid mites (Gamasina: Phytoseiidae) in Finnish apple plantations and their surroundings
}

\author{
Tuomo Tuovinen
}

Tuovinen, T. 1993: Identification and occurrence of phytoseiid mites (Gamasina: Phytoseiidae) in Finnish apple plantations and their surroundings. — Entomol. Fennica 4:95-114.

Twelve species in eight genera of the family Phytoseiidae have been found to occur on apple trees and an additional eight species on various trees or bushes in their surroundings in Finland. Identification keys, supported by figures, are presented for 23 species, including three introduced species. The keys are based on published literature and on the examination of adult females collected in 1985-1991. The aim of the keys and descriptions is to help non-taxonomist researchers with identification. Notes on the occurrence of the species on apple and other host plants in Finland are included.

Tuomo Tuovinen, Institute of Plant Protection, Agricultural Research Centre of Finland, SF-31600 Jokioinen, Finland

\section{Introduction}

Phytoseiid mites are known as effective natural enemies of spider mites (Tetranychidae) (Helle \& Sabelis 1985). In Scandinavia, Hansen \& Johnsen (1986), Edland (1987) and Karg \& Edland (1987) have recently published records on Phytoseiidae.

In Finland phytoseiid mites were observed to be natural enemies of the European red spider mite Panonychus ulmi (Koch) on apple trees as early as the 1930s (Listo et al. 1939). Previous identification and reports of Phytoseiidae in Finland were made by Oudemans (1915), who described Euseius (Seiulus) finlandicus (Oudemans) and identified Phytoseius macropilis (Seiulus spoofi) (Banks) on Salix sp. and later E. finlandicus on Prunus domestica, and by Athias-Henriot (ref. Moraes et al. 1986), who identified E. finlandicus on $P$. domestica. No comprehensive data on phytoseiid mites were available subsequent to these notes until Kropczynska and Tuovinen $(1987,1988)$ reported on a study made in 1985.

The material presented here proves that phytoseiid mites are common on the leaves of various wild and cultivated trees and bushes (Table 1). However, although at least twenty species occur naturally outdoors in Finland, only a few of them are common and widespread on a variety of host plants. E. finlandicus, P. macropilis, and Paraseiulus soleiger (Ribaga) are so widely distributed and occur in such amounts that they can be expected to play important roles on apple trees (Table 2). Also the other species are considered to be important natural resources, although their relevance to the natural or biological control of pests needs further studies on different host plants.

As the value of phytoseiid mite species in integrated control is variable, correct diagnosis 
of the species is essential. Quite often, the same species from different regions have been described as different species by many authors. The terminology of the morphological features differs between authors, causing confusion for non-taxonomists. The aim of this study is to provide keys for identification of the phytoseiid genera and species found in Finland, and update the data on the occurrence of phytoseiid mites in Finnish apple plantations and their surroundings.

Table 1. List of host plants of Phytoseiidae in Finland.

\begin{tabular}{|c|c|}
\hline Host plant & Phytoseiid species \\
\hline Acer platanoides & S. aceri, P. triporus, A. bakeri, A. richteri, E. finlandicus \\
\hline Aesculus hippocastani & P. macropilis, P. triporus, E. finlandicus \\
\hline Alnus glutinosa & A. rhenanus \\
\hline A. incana & E. finlandicus \\
\hline Amelanchier spicata & E. finlandicus \\
\hline Aristolochia macrophylla & E. finlandicus, $A$. reductus \\
\hline Betula lutea & P. soleiger, E. finlandicus \\
\hline Cornus alba & E. finlandicus \\
\hline Corylus avellana & P. macropilis, P. soleiger, P. triporus, E. finlandicus \\
\hline Crataegus coccinea & P. soleiger, A. thenanus, E. finlandicus, $A$. subsolidus \\
\hline Fagus grandifolia & P. macropilis, $P$. soleiger, E. finlandicus \\
\hline Fragaria $\times$ ananassa & $\begin{array}{l}\text { P. macropilis, } P \text {. talbii, A. thenanus, } P \text {. okanagensis, E. finlandicus, (A. cucumeris), } \\
\text { A. reductus, } A \text {. tenuis, } A \text {. zwoelferi }\end{array}$ \\
\hline F. vesca & $P$. triporus, $E$. finlandicus, $A$. reductus \\
\hline Fraxinus excelsior & P. soleiger, E. finlandicus \\
\hline Juglans ailanthifolia & P. talbii, $A$. menanus, E. finlandicus \\
\hline J. cinerea & $P$. soleiger, $A$. rhenanus, $E$. finlandicus \\
\hline J. mandschurica & P. soleiger, E. finlandicus \\
\hline Lonicera xylosteum & P. macropilis, E. finlandicus, $A$. reductus \\
\hline Malus domestica & $\begin{array}{l}\text { P. macropilis, } P \text {. soleiger, P. talbii, } P \text {. triporus, A. bakeri, A. thenanus, A. richteri, A. } \\
\text { suecicus, A. viktorovi, (P. persimilis), E. finlandicus, A. reductus, A. subsolidus }\end{array}$ \\
\hline Prunus cerasus & $P$. macropilis, $P$. triporus, $A$. rhenanus, E. finlandicus \\
\hline P. padus & P. macropilis, P. triporus, E. finlandicus, A. subsolidus \\
\hline Pterocarya rhoifolia & $P$. soleiger, $P$. triporus, $T$. andrei, E. finlandicus \\
\hline Pyrus communis & E. finlandicus \\
\hline Quercus robur & P. soleiger, E. finlandicus \\
\hline Ribes nigrum & $\begin{array}{l}\text { P. macropilis, P. soleiger, A. bakeri, A. thenanus, T. laurae, P. okanagensis, E. } \\
\text { finlandicus, A. zwoelferi }\end{array}$ \\
\hline R. rubrum & $\begin{array}{l}\text { P. macropilis, P. juvenis, P. triporus, A. bakeri, A. thenanus, T. pyri, E. finlandicus, } \\
\text { A. reductus }\end{array}$ \\
\hline R. uva-crispa & P. triporus, E. finlandicus \\
\hline Rubus fruticosus & P. macropilis, E. finlandicus \\
\hline R. idaeus & P. macropilis, P. juvenis, P. soleiger, A. rhenanus, E. finlandicus, A. reductus \\
\hline R. odoratus & P. triporus, E. finlandicus \\
\hline Salix caprea & P. macropilis, E. finlandicus \\
\hline Salix sp & P. macropilis, $P$. soleiger, E. finlandicus \\
\hline Sorbus aucuparia & P. macropilis, P. triporus, A. richteri, A. rhenanus, E. finlandicus \\
\hline S. thuringiaca & P. macropilis, P. soleiger, E finlandicus \\
\hline Tilia americana & P macropilis, E. finlandicus \\
\hline T. cordata & $P$. soleiger, E. finlandicus \\
\hline T. euchlora & P. soleiger, E. finlandicus \\
\hline Tussilago farfara & A. reductus \\
\hline Ulmus glabra & P. macropilis, P. soleiger, P. triporus, E. finlandicus, A. reductus \\
\hline Urtica dioica & E. finlandicus, $A$. reductus \\
\hline Viburnum opulus & P. macropilis, E. finlandicus \\
\hline
\end{tabular}




\section{Materials and methods}

Phytoseiid mites were collected in southern Finland during 1985-1991 from sprayed and unsprayed fruit trees as well as other deciduous trees and bushes, in forest margins or nearby apple plantations. A normal leaf sample consisted of 100 leaves taken from a few plants at the same locality. The material used in this study included 270 leaf samples of 48 plant species.

The leaves were either inspected under a stereomicroscope or they were first soaked in hot $\left(65-70^{\circ} \mathrm{C}\right)$ soapy water for one day and then sieved to extract mites. Phytoseiid mites were then stored in $70 \%$ alcohol before mounting. Mites were mounted using a medium prepared as follows: fine grinded, purified gum arabic, $50 \mathrm{~g}$, and distilled water, $50 \mathrm{ml}$, are mixed carefully; the mixture is then preserved for 3-4 days in a closed bottle at $+35^{\circ} \mathrm{C}$, and after that chloralhydrate, $125 \mathrm{~g}$, and glycerol, $30 \mathrm{ml}$, are added and mixed in. After 10 days preservation at $+35^{\circ} \mathrm{C}$ the mixture is usable. The specimens were macerated in $70 \%$ lactic acid and then washed in alcohol before mounting. The cover slides were sealed with nail polish.

Mites were examined using 250-500 $\times$ magnification. The lengths of the idiosoma, dorsal

Table 2. Relative abundance (\%) of phytoseiid mite species on apple leaf samples and number of samples including the species in 1985 and 1989.

\begin{tabular}{lrrr}
\hline & \multicolumn{2}{c}{ Species } & Samples \\
& 1985 & 1989 & $1985-89$ \\
\hline Euseius finlandicus & 31.5 & 45.4 & 70 \\
Phytoseius macropilis & 37.0 & 28.9 & 60 \\
Paraseiulus soleiger & 25.5 & 12.6 & 41 \\
Amblyseius subsolidus & 3.2 & 10.0 & 13 \\
Amblyseius reductus & 1.6 & 0.9 & 13 \\
Anthoseius rhenanus & 0.0 & 1.3 & 7 \\
Paraseiulus triporus & - & 0.8 & 8 \\
Anthoseius suecicus & 0.8 & 0.0 & 2 \\
Anthoseius richteri & 0.2 & 0.1 & 6 \\
Anthoseius bakeri & 0.2 & - & 1 \\
Paraseiulus talbii & - & 0.0 & 1 \\
Anthoseius viktorovi & - & 0.0 & 1 \\
Total individuals/samples & 1920 & 2474 & 105 \\
\hline
\end{tabular}

setae and the longest macroseta on leg IV were measured. The figures were drawn from microphotographs taken from representative specimens.

\section{Species of Phytoseiidae}

Phytoseiids are free-living, terrestrial mites and they occur on foliage, bark, and humus in all parts of the world (Chant 1985).

The following description is based on Chant (1985). Phytoseiids are 300-500 $\mu \mathrm{m}$ long, their bodies are divided into two major parts, the gnathosoma, which includes the chelicerae and palps, and the idiosoma, to which the four pairs of legs are attached (Fig. 1B). The idiosoma is covered by an undivided dorsal shield, which may be smooth or sclerotized and sculptured or reticulated. The dorsal shield bears at most 20 pairs of setae, excluding the sublateral setae, which may also be situated on the dorsal shield (in Phytoseius) (Fig. 1A). There are 2 pairs of sublateral setae, $\mathrm{r} 3$ and $\mathrm{Rl}$ (in Finnish genera).

Ventrally, phytoseiids have three sclerotized shields: the sternal shield, genital shield and ventrianal shield (Fig. 1B). The ventrianal shield bears 1-4 pairs of setae anterior to the anus (preanal setae), a pair of para-anal setae on both sides of the anus and a single postanal seta. The shape of the ventrianal shield is variable.

The gnathosoma is used for capturing and eating prey, and in the male also for copulation. The female chelicera consists of a fixed digit and a movable digit (Fig. 2B). There are several teeth on the fixed digit and fewer on the movable digit. The male chelicera has a fleshy spermatodactyl (Fig. 2C), which transfers spermatophores from the genital opening to the female sperm induction pore. The spermatophore is then transferred via a major duct to the spermatheca and into the cervix (Fig. 2A).

Adult males are usually smaller than females. Their dorsal setae are in most cases arranged as in females, but they differ in shape of ventrianal shield and in form of chelicerae. Phytoseiid larvae have only three pairs of legs. Larvae and nymphal stages are smaller and they have fewer setae on the dorsal shield than adults. 

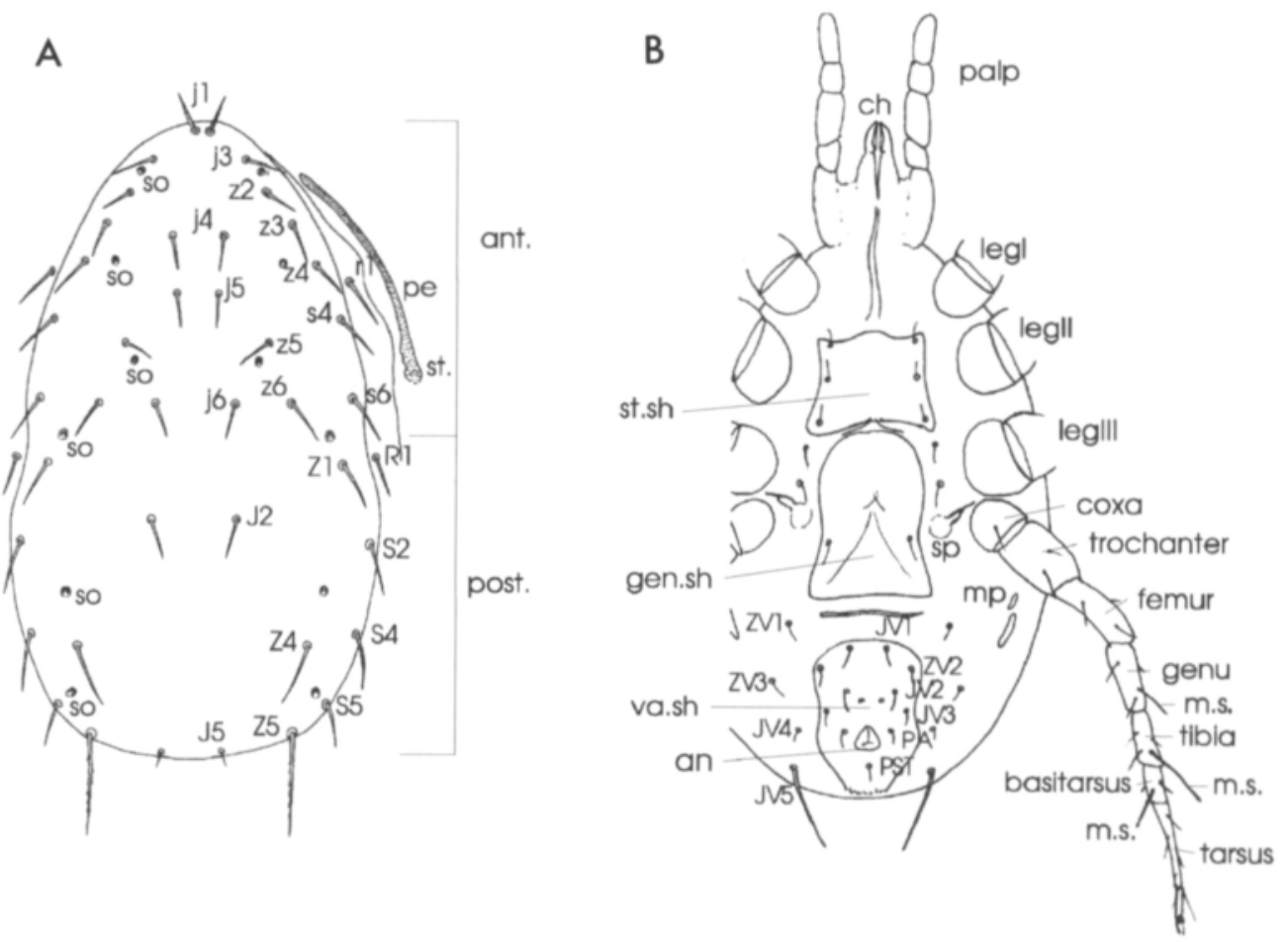

Fig. 1. Scheme of adult female phytoseiid. - A. Dorsal shield with terminology and locations of dorsal setae and main pores. ant. = anterior part of dorsal shield (proscutum); post. = posterior part of dorsal shield (postscutum); pe = peritreme; so = solenostome; st. = stigma. Setal nomenclature: $\mathrm{jl}=$ verticals; j3, z2, z3, z4, s4, s6 = prolateral setae; j4, j5, j6, J2 = dorsocentral setae; Z5, z6 = promediolateral setae; Z1, S2, S4, S5, Z5 = postlateral setae; Z3, $\mathrm{Z} 4$ = postmediolateral setae; J5 = clunals. (Z3 are situated anterior to Z4; if Z3 are present, Zl or s6 are missing). - B. Ventral view with terminology and locations of diagnostic characteristics. ch = chelicera; gen.sh = genital shield; st.sh = sternal shield; va.sh = ventrianal shield, an = anus, po = pore on ventrianal shield; leg IV: coxa, trochanter, femur, genu, tibia, basitarsus, tarsus, m.s. = macroseta; $\mathrm{mp}=$ metapodal plates; $\mathrm{sp}=\mathrm{spermatheca}$. Setal nomenclature: JVI, JV2, JV3, JV4, JV5 = medial setae; ZVI, ZV2, ZV3 = mediolateral setae; PA = para-anal setae; PST = post-anal seta.

\subsection{Keys and descriptions}

The identification keys for females have been worked out using the mite specimens collected to determine the characteristics of the species. The descriptions and keys of Chant (1957, 1959, 1965), Chant \& Hansell (1971), Chant \& YoshidaShaul (1982, 1987), Dosse (1958), Karg (1970, 1971, 1982, 1983, 1991), Beglyarov (1981), and Miedema (1987) have been used as reference guides for keys. The main synonyms are from the above references and from Moraes et al. (1986).

Chant \& Yoshida-Shaul (1986) divided the family Phytoseiidae into four subfamilies, Phytoseiinae, Amblyseiinae, Chantiinae, and
Cydnodromellinae. This division is used in the following keys. The European phytoseiids belong to the subfamilies Phytoseiinae and Amblyseiinae (Evans 1987).

In the keys to subfamilies and genera, the concepts of Evans (1987), based mainly on Karg (1983), have been followed, except that the genus Amblyseius Berlese also includes here the genera Neoseiulus Hughes and Typhlodromips De Leon. The genus Anthoseius De Leon is presented as a separate genera in Karg (1983), and this concept is followed here.

The keys to genera are based primarily on the presence and relative lengths of dorsal setae and on the shape of the ventrianal shield and the number of setae on it (Fig. 1A, B). For the identi- 

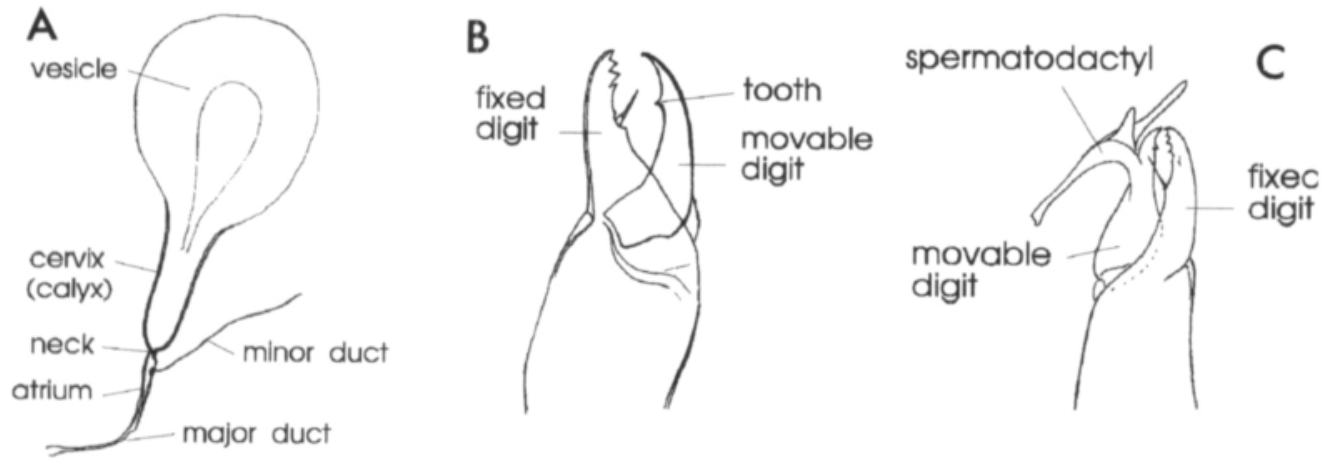

Fig. 2. Diagnostic characters of adult phytoseiid mite. - A. Spermatheca. - B. Female chelicera. - C. Male chelicera.

fication of the species the number of solenostomes or pores on the dorsal shield and the presence of pores on the ventrianal shield, and the shape of the spermatheca (Fig. 2A) has to be considered. Other characteristics, the presence of macrosetae on the basitarsus, tibia and genu of leg IV (Fig. 1B), the number of setae on the genu of leg II, the extension of the peritremes (Fig. 1A), and the number of teeth on the movable digit of the chelicerae (Fig. 2B) are used only occasionally in the keys. The mean, minimum and maximum of 10-20 measurements are presented, if enough specimens have been available. The keys to genera and species are valid only for the included species.

Different terminologies of the dorsal setae have been used by various authors, and that of Rowell et al. (1978) is adopted here (Table 3).

\section{Key to genera (females) of Phytoseiidae}

1. 6 pairs $(\mathrm{j} 3, \mathrm{z} 2, \mathrm{z} 3, \mathrm{z} 4, \mathrm{~s} 4, \mathrm{~s} 6)$ of prolateral setae present (Phytoseinae)

- 4 pairs $(\mathrm{j} 3, \mathrm{z} 2, \mathrm{z} 4, \mathrm{~s} 4)$ of prolateral setae present (Amblyseinae)

2. Some dorsal setae, especially s4, s6, Z4 and Z5 thick and thorn-like; S2, S4 and S5 absent; J2 absent; r3 on dorsal shield; $\mathrm{Rl}$ absent

Phytoseius, p. 100
Table 3. Comparison of setal terminology for dorsum of idiosoma in the descriptive taxonomy of Phytoseiidae. - Row $=$ Rowell et al. 1978, Karg = Karg 1971, 1981, Beg = Beglyarov 1980, Kol = Kolodochka 1984, Den = Denmark et al. 1984.

\begin{tabular}{|c|c|c|c|c|c|}
\hline Setae & Row & Karg & Beg & $\mathrm{Kol}$ & Den \\
\hline $\begin{array}{l}\text { Anterior } \\
\text { dorsocentral }\end{array}$ & $\begin{array}{l}j 1 \\
j 3 \\
j 4 \\
j 5 \\
j 6\end{array}$ & $\begin{array}{l}i 1 \\
i 2 \\
i 3 \\
i 4 \\
i 5\end{array}$ & $\begin{array}{l}\text { D1 } \\
\text { L1 } \\
\text { D2 } \\
\text { D3 } \\
\text { D4 }\end{array}$ & $\begin{array}{l}\text { D1 } \\
\text { AM1 } \\
\text { D2 } \\
\text { D3 } \\
\text { D4 }\end{array}$ & $\begin{array}{l}\text { V } \\
\text { L1 } \\
\text { D1 } \\
\text { D2 } \\
\text { D3 }\end{array}$ \\
\hline mediolateral & $\begin{array}{l}z 2 \\
z 3 \\
z 4 \\
z 5 \\
z 6\end{array}$ & $\begin{array}{l}\text { s2 } \\
\text { s3 } \\
z 1 \\
z 2 \\
z 3\end{array}$ & $\begin{array}{l}\text { L2 } \\
\text { L3 } \\
\text { L4 } \\
\text { AM } \\
-\end{array}$ & $\begin{array}{l}\text { AL1 } \\
\text { AL2 } \\
\text { AL3 } \\
\text { AM2 } \\
\text { AM3 }\end{array}$ & $\begin{array}{l}\text { L2 } \\
\text { L3 } \\
\text { L4 } \\
\text { M1 } \\
-\end{array}$ \\
\hline lateral & $\begin{array}{l}\mathrm{s} 4 \\
\mathrm{~s} 6\end{array}$ & $\begin{array}{l}\text { s5 } \\
\text { s7 }\end{array}$ & $\begin{array}{l}\mathrm{L} 5 \\
\mathrm{~L} 6\end{array}$ & $\begin{array}{l}\text { AL4 } \\
\text { AL5 }\end{array}$ & $\begin{array}{l}\mathrm{L} 5 \\
\mathrm{~L} 6\end{array}$ \\
\hline marginal & r3 & r5 & AS & AS & S1 \\
\hline $\begin{array}{l}\text { Posterior } \\
\text { dorsocentral }\end{array}$ & J2 & 12 & D5 & D5 & D4 \\
\hline mediolateral & $\begin{array}{l}\text { J5 } \\
\text { Z1 } \\
\text { Z3 } \\
\text { Z4 } \\
\text { Z5 }\end{array}$ & $\begin{array}{l}15 \\
Z 1 \\
Z 3 \\
Z 4 \\
Z 5\end{array}$ & $\begin{array}{l}\text { D6 } \\
- \\
\bar{P} \\
\text { PL } \\
\text { PL }\end{array}$ & $\begin{array}{l}\text { D6 } \\
\text { ML } \\
\text { PM1 } \\
\text { PM2 } \\
\text { PM3 }\end{array}$ & $\begin{array}{l}\text { C1 } \\
\text { M2 } \\
- \\
\text { M3 } \\
\text { L10 }\end{array}$ \\
\hline lateral & $\begin{array}{l}\text { S2 } \\
\text { S4 } \\
\text { S5 }\end{array}$ & $\begin{array}{l}\text { S2 } \\
\text { S4 } \\
\text { S5 }\end{array}$ & $\begin{array}{l}\text { L7 } \\
\text { L8 } \\
\text { L9 }\end{array}$ & $\begin{array}{l}\text { PL1 } \\
\text { PL2 } \\
\text { PL3 }\end{array}$ & $\begin{array}{l}\text { L7 } \\
\text { L8 } \\
\text { L9 }\end{array}$ \\
\hline marginal & R1 & $\mathrm{R} 1$ & PS & PS & $\mathrm{S} 2$ \\
\hline
\end{tabular}


- s4 and s6 never thick and thorn-like; 1-3 pairs of setae S2, S4 and S5 present; J2 present; r3 not on dorsal shield; Rl present .....

3. $\mathrm{Zl}$ present …........................................ Seiulus, p. 100

- $\mathrm{Zl}$ absent ..................................................................... 4

4. S5 present ................................................................ 5

- S5 absent .................................. Typhlodromus, p. 103

5. z6 present, additionally $\mathrm{Z} 3$ may be present; JV2 absent ............................................. Paraseiulus, p. 101

- z6 and Z3 always absent; JV2 present .. Anthoseius, p. 102

6. J2 absent ................................................................ 7

- J2 present ........................................................................ 8

7. j6 long $(>100 \mu \mathrm{m})$, equal to about one half of the width of the dorsal shield; S4 absent; preanal setae absent

Phytoseiulus, p. 104

— j6 short (ca. $10 \mu \mathrm{m})$; S4 present; 2 or 3 pairs of preanal setae ........................................ Proprioseiopsis, p. 104

8. 3 pairs of preanal setae arranged in a 'zigzag' row on anterior part of ventrianal shield .......... Euseius, p. 105

- 3 pairs of preanal setae on ventrianal shield not arranged as above . Amblyseius, p. 105

\section{Genus Phytoseius Ribaga}

\section{Key to species}

1. $s 4$ considerably longer than other dorsal setae; $s 4: s 6=$ ca. 1.4 macropilis

- $s 4$ about as long as $s 6$ juvenis

\section{Phytoseius macropilis (Banks)}

Fig. 3

Sejus macropilis Banks; Phytoseius (Seiulus) spoofi (Oudemans), Nesbitt; Typhlodromus macropilis (Banks), Westerboer \& Bernhard; Dubininellus macropilis (Banks), according to Karg (1991).

Diagnosis: Idiosoma $341 \mu \mathrm{m}$ (320-368). Dorsal shield pale, variably sclerotized and heavily sculptured. Ventrianal shield smooth, usually with $2-3$ pairs of preanal setae (or unpaired $2+3,1+3$ or $1+2$ ). Shape of spermatheca variable, but always with a wide base, cervix only partly sclerotized, not always easily detectable. Movable digit of chelicerae has 1 tooth. Lobe-ending macrosetae ( $85 \mu \mathrm{m}, 72-96)$ present on tibia of leg IV, and much shorter macrosetae on genu and basitarsus.

Distribution and host plants: Common on deciduous trees and bushes; found on Aesculus, Corylus, Fagus, Fragaria, Malus, Prunus, Ribes,
Rubus, Salix, Sorbus, Tilia, Ulmus and Viburnum. After E. finlandicus, P. macropilis was the commonest species on apple trees. It has been recorded on numerous deciduous trees and bushes and some herbaceous plants from Europe, Asia and North and South America (Moraes et al. 1986).

\section{Phytoseius juvenis Wainstein \& Arutunjan}

Fig. 4

Dubininellus juvenis (Wainstein \& Arutunjan), according to Karg (1991).

Diagnosis: Idiosoma $325 \mu \mathrm{m}$ (310-340). Dorsal shield pale, variably sclerotized and heavily sculptured. Ventrianal shield smooth, with 1-2 pairs of preanal setae (or unpaired $2+1,0+1$ or $2+3$ ). Spermatheca wide with a bowed neck. Movable digit of chelicerae has 1 tooth. Lobeending macrosetae (93 $\mu \mathrm{m} \mathrm{84-112)} \mathrm{on} \mathrm{tibia} \mathrm{of}$ leg IV and shorter macrosetae on genu and basitarsus.

Distribution and host plants: Found on Ribes rubrum in Kokemäki $\left(61^{\circ} 16^{\prime} \mathrm{N}, 22^{\circ} 15^{\prime} \mathrm{E}\right)$ and on Rubus idaeus in Åland $\left(60^{\circ} 15^{\prime} \mathrm{N}, 19^{\circ} 58^{\prime} \mathrm{E}\right) . P$. juvenis has been recorded on fruit trees and berry plants in Eastern Europe (Karg 1991).

\section{Genus Seiulus Berlese}

\section{Seiulus aceri (Collyer)}

Fig. 5

Typhlodromus aceri Collyer; Typhloctonus aceri (Collyer), according to Moraes et al. (1986).

Diagnosis: Idiosoma $328 \mu \mathrm{m}$ (320-336). Dorsal shield reticulated and sclerotized, with 3 pairs of small solenostomes. Ventrianal shield rectangular, with 4 pairs of preanal setae, and with none or 1 pair of small pores. Spermatheca with a long neck. Movable digit of chelicerae has 1 small, hardly visible tooth. No macrosetae on leg IV.

Distribution and host plants: Found only on Acer platanoides. S. aceri is specialized in regard to its hostplants. It is recorded from Acer platanoides, A. campestre, Corylus sp., Cerasus 
sp. Juglans sp., Prunus sp., Rubus sp. and Zelkova sp. in Europe and Asia (Moraes et al. 1986).

\section{Genus Paraseiulus Muma}

\section{Key to species}

1. $\mathrm{Z} 3$ present

- Z3 absent talbii

2. Dorsal shield without prominent pores; spermatheca narrow, bowed horn-shaped soleiger

- 3 pairs of prominent pores on dorsal shield; spermatheca with wide cervix triporus

\section{Paraseiulus talbii (Athias-Henriot)}

Fig. 6

Typhlodromus talbii Athias-Henriot; Paraseiulus subsoleiger Wainstein, Karg; Typhlodromus tetramedius Zaher \& Shehata, Chant \& Yoshida-Shaul; Seiulus amaliae Ragusa \& Swirski, Chant \& Yoshida-Shaul; Paraseiulus ostiolatus Athias-Henriot, Chant \& Yoshida-Shaul; Bawus talbii (Athias-Henriot), according to Moraes et al. (1986).

Diagnosis: Idiosoma $381 \mu \mathrm{m}$ (356-400). Dorsal shield distinctly reticulated and strongly sclerotized, especially in posterior part, with 3 pairs of distinct, invaginated solenostomes. Ventrianal shield narrow, 'slipper-shaped', sparsely striated, with 2 pairs of preanal setae. Spermatheca cervix wide, vase-shaped. Movable digit of chelicerae without teeth. No macrosetae on leg IV. Note: One female missing setae z6 was found on wild Malus sp. In Paraseiulus some variation in number of dorsal setae has been noted earlier (Chant \& Yoshida-Shaul 1989).

Distribution and host plants: Found on Fragaria $\times$ ananassa, Juglans ailanthifolia, Malus sp. P. talbii has previously been recorded in Europe and Asia from many trees and bushes, including fruit trees (Moraes et al. 1986).

\section{Paraseiulus soleiger (Ribaga)}

Fig. 7

Seiulus soleiger Ribaga; Typhlodromus soleiger (Ribaga), Nesbitt; Paraseiulus incognitus Wainstein \& Arutun- jan, 1967, Chant \& Yoshida-Shaul; Typhlodromus trimediosetus Xin, Liang \& Ke, Chant \& YoshidaShaul.

Diagnosis: Idiosoma $324 \mu \mathrm{m}$ (304-364). Dorsal shield strongly sclerotized and reticulated. Ventrianal shield weakly striated or reticulated, with 2 pairs of preanal setae. Spermatheca long, horn-shaped. Movable digit of chelicerae without teeth. No macrosetae on leg IV. Note: A few females missing setae $\mathrm{z} 6$ were found (less than 1 $\%$ of the material collected). Males of $P$. soleiger always lack setae z6.

Distribution and host plants: Widespread, occasionally in large numbers, found on Betula lutea, Corylus avellana, Crataegus coccinea, Fagus grandifolia, Fraxinus excelsior, Juglans cinerea, J. mandshurica, Malus sp., Pterocarya rhoifolia, Quercus robur, Ribes nigrum, Rubus idaeus, Sorbus thuringiaca, Tilia cordata, Tilia $\times$ euchlora, Ulmus glabra. P. soleiger has been recorded on numerous trees and bushes, and also in litter and grass, from Europe, Asia and North America (Moraes et al. 1986). It preys especially on tydeid mites (Dosse 1956).

\section{Paraseiulus triporus (Chant \& Yoshida-Shaul)}

Fig. 8

Typhlodromus triporus Chant \& Yoshida-Shaul.

Diagnosis: Idiosoma $390 \mu \mathrm{m}$ (360-408). Dorsal shield strongly sclerotized and reticulate, with 3 pairs of distinct, invaginated solenostomes. Ventrianal shield lightly striated, with 2 pairs of preanal setae. Spermatheca variable in shape, weakly sclerotized. Movable digit of chelicerae has 1 tooth. No macrosetae on leg IV. Note: One specimen with a single seta $\mathrm{J}$ between $\mathrm{J} 2$ and $\mathrm{j} 6$ was found.

Distribution and host plants: Found in Finland on Acer platanoides, Aesculus hippocastani, Corylus avellana, Fragaria vesca, Malus sp., Prunus avium, Prunus padus, Pterocarya rhoifolia, Ribes rubrum, Ribes uva-crispa, Sorbus aucuparia, Rubus odoratus, Ulmus glabra. P. triporus has previously been reported from Europe and North America on many orchard trees, as well as other deciduous trees and bushes (Moraes et al. 1986). 


\section{Genus Anthoseius De Leon}

\section{Key to species}

1. Ventrianal shield with 3 pairs of preanal setae ........ 2

- Ventrianal shield with 4 pairs of preanal setae ........ 3

2. Movable digit with 2 teeth; genu II with 6 setae; no distinct macrosetae on basitarsus IV; distinct pores close to $\mathrm{S} 5$ viktorovi

- Movable digit with 1 tooth; genu II with 7 setae; macrosetae on basitarsus IV ending in a small lobe; distance of pores from the base of S5 about the same as the length of S5 suecicus

3. Spermatheca cilinder-shaped; movable digit with 1 tooth. rhenanus

- Spermatheca with long cervix; movable digit with 2 or 3 teeth

4. Ventrianal shield widest anteriorly; movable digit with 2 teeth richteri

- Ventrianal shield widest medially; movable digit with 3 teeth..... . bakeri

\section{Anthoseius viktorovi Wainstein}

Fig. 9

Amblydromella viktorovi (Wainstein), according to Moraes et al. (1986).

Diagnosis: Idiosoma $370 \mu \mathrm{m}$. Dorsal shield lightly reticulated and sclerotized, with 4-5 pairs of pores, 3 distinct ones, one pair close to setae S5. Three pairs of preanal setae and one pair of faint pores on ventrianal shield. Shape of spermatheca conical. The movable digit of chelicerae has 2 teeth. No macrosetae on leg IV.

Distribution and host plants: Only one female was found on Malus domestica, Pälkäne $\left(61^{\circ} 20^{\prime} \mathrm{N}, 24^{\circ} 12^{\prime} \mathrm{E}\right)$. A. viktorovi has previously been recorded on pine in Yaroslavl Province, Russia (Moraes et al. 1986).

\section{Anthoseius suecicus (Sellnick)}

Fig. 10

Neoseiulus suecicus Sellnick; Typhlodromus suecicus (Sellnick), Karg; Amblydromella suecica (Sellnick), according to Moraes et al. (1986); Typhlodromus gilvus Wainstein (E. Shaul in litt.).
Diagnosis: Idiosoma $387 \mu \mathrm{m}$ (380-392). Dorsal shield lightly reticulate and sclerotized, with variable number of pores, of which 3 pairs are distinct. 3 pairs of preanal setae on ventrianal shield (or unpaired $2+3$ ), 1 pair of pores. Spermatheca cup-shaped, with a short atrium. Movable digit of chelicerae has 1 tooth. Hardly differentiated, lobe-ending macrosetae ( $25 \mu \mathrm{m}, 24-28)$ on basitarsus on leg IV. - A. suecicus and A. gilvus (Wainstein) are proposed as synonyms (Eiko Shaul, pers. comm. 1989).

Distribution and host plants: Found only on Malus domestica in Mietoinen $\left(60^{\circ} 47^{\prime} \mathrm{N}\right.$, $\left.21^{\circ} 24^{\prime} \mathrm{E}\right)$ and Pälkäne $\left(61^{\circ} 47^{\prime} \mathrm{N}, 24^{\circ} 12^{\prime} \mathrm{E}\right) . A$. suecicus has previously been recorded on grass in Sweden, and on bird cherry in Yaroslavl, Russia, where it was described as A. gilvus (Moraes et al. 1986).

\section{Anthoseius rhenanus (Oudemans)}

Fig. 11

Seiulus rhenanus Oudemans; Typhlodromus foenilis Oudemans, Chant; Typhlodromus (Neoseiulus) rhenanus (Oudemans), Nesbitt; Typhlodromus kazachstanicus Wainstein, Chant; Amblydromella (Seiulus) rhenana (Oudemans), according to Moraes et al. (1986).

Diagnosis: Idiosoma $323 \mu \mathrm{m}$ (312-328). Dorsal shield reticulate and sclerotized, with 3 pairs of small indistinct pores. Setae Z5, Z4 and S5 faintly serrated. Usually 4 pairs of preanal setae and 1 pair of small, sometimes invisible pores on ventrianal shield. Spermatheca cylindrical. Movable digit of chelicerae has 1 tooth. Slightly differentiated macrosetae $(29 \mu \mathrm{m}, 25$ 32) on basitarsus on leg IV.

Distribution and host plants: Found on Alnus glutinosa, Crataegus coccinea, Fragaria $\times$ ananassa, Juglans ailanthifolia, Malus sp., Prunus avium, Ribes nigrum, $R$. rubrum, Rubus idaeus, Sorbus aucuparia. A. rhenanus has been recorded on numerous trees, bushes and herbaceous plants in Europe, Asia and North America (Moraes et al. 1986). In the present study, $A$. rhenanus occurred commonly on unsprayed strawberries. 


\section{Anthoseius richteri (Karg)}

Fig. 12

Typhlodromus richteri Karg; Amblydromella (Typhlodromus richteri (Karg), according to Moraes et al. (1986).

Diagnosis: Idiosoma $432 \mu \mathrm{m}$ (416-464). Dorsal shield distinctly sclerotized and sculptured, with 4 pairs of pores, sometimes hardly visible. Dorsal setae relatively thick and stiff, setae Z5, Z4 and S4 faintly serrated. Ventrianal shield widest in anterior part, with 4 pairs of preanal setae and 1 pair of pores. Spermatheca funnel-shaped with a long, narrow, often bowed neck. Movable digit of chelicerae has 2 teeth. Macrosetae (44 $\mu \mathrm{m}, 40-46)$ on basitarsus of leg IV. - In the description of A. richteri there are Zl instead of S2 setae (Karg 1970). However, this type of pattern is not listed in the setal patterns presented by Chant \& Yoshida-Shaul (1989).

Distribution and host plants: Found on Acer platanoides, Malus domestica and Sorbus aucuparia. A. richteri has been recorded on deciduous trees in Central Europe and in Norway (Karg \& Edland 1987, Karg 1991).

\section{Anthoseius bakeri (Garman)}

Fig. 13

Seiulus bakeri Garman; Typhlodromus bakeri (Garman), Nesbitt; Amblydromella (Seiulus) bakeri (Garman), according to Moraes et al. 1986.

Diagnosis: Idiosoma $402 \mu \mathrm{m}$ (328-480). Dorsal shield heavily sclerotized and sculptured, with no distinct pores. Setae Z5 serrated. Ventrianal shield widest in medial part, with 4 pairs of preanal setae and a pair of faint pores (not always visible). Spermatheca horn-shaped, with a long and narrow atrium. Movable digit of chelicerae has 3 teeth. Macrosetae $(34 \mu \mathrm{m}, 31-$ 40) on basitarsus of leg IV.

Distribution and host plants: Found on Malus sp., Ribes nigrum and $R$. rubrum. A. bakeri is a bark inhabiting species, and may be more common on apple than the leaf samples show (Karg 1991). It has been recorded on numerous trees and bushes in North America, Europe, Asia and Australia (Moraes et al. 1986).

\section{Genus Typhlodromus Scheuten}

\section{Key to species}

1. 4 pairs of prominent pores on dorsal shield; 1 pair of pores anterior to $\mathrm{Z} 4$....

- 3 pairs of pores on dorsal shield; no pores anterior to setae Z4 pyri

2. Peritremes extend forward between $\mathrm{j} 3$ and $\mathrm{z} 2$; spermatheca spur-shaped; Z5 about twice as long as setae Z4 . laurae

- Peritremes extend forward to the level of $\mathrm{z} 4$; spermatheca wide V-shaped funnel without neck; Z5 only slightly longer than $\mathrm{Z} 4$ andrei

\section{Typhlodromus pyri Scheuten}

Fig. 14

Diagnosis: Idiosoma $342 \mu \mathrm{m}$ (336-348). Dorsal shield lightly sclerotized and distinctly reticulated, with 3 pairs of prominent solenostomes, but no pores anterior to setae Z4. Setae Z4 and Z5 slightly serrated. Ventrianal shield with four pairs of preanal setae $(20 \mu \mathrm{m})$. Spermatheca bell-shaped. Movable digit of chelicerae has 2 teeth. Macrosetae $(38 \mu \mathrm{m}, 36-40)$ on basitarsus of leg IV.

Distribution and host plants: Found only in Åland $\left(60^{\circ} 15^{\prime} \mathrm{N}, 19^{\circ} 58^{\prime} \mathrm{E}\right)$ on red currant Ribes rubrum and black currant $R$. nigrum. T. pyri is widely used in the biological control of spider mites in orchards. As T. pyri has not been found on apple trees nor on other trees in Finland it is possible that it cannot overwinter here on trees. The occurrence of the species on currants in Åland, where the climate is more favourable than on the mainland, support this conclusion. In Norway, $T$. pyri occurs commonly on apple trees (Edland 1987). T. pyri has been recorded on numerous trees and bushes in Europe, Asia, North Africa, North America, Australia and New Zealand (Chant \& Yoshida-Shaul 1987).

\section{Typhlodromus laurae Arutunjan}

Fig. 15

Diagnosis: Idiosoma $363 \mu \mathrm{m}$. Dorsal shield reticulated and lightly sclerotized, with 4 pairs of 
prominent pores, one of them anterior to setae Z4. Setae Z5 with very faint serration. Ventrianal shield with 4 pairs of preanal setae $(15 \mu \mathrm{m})$. Spermatheca narrow spur-shaped. Movable digit of chelicerae has 2 teeth. Macrosetae on basitarsus $(50 \mu \mathrm{m})$, and shorter macrosetae on tibia of leg IV.

Distribution and host plants: Only one female found in Piikkiö $\left(60^{\circ} 23^{\prime} \mathrm{N}, 22^{\circ} 33^{\prime} \mathrm{E}\right)$ on Ribes nigrum. T. laurae has been recorded on Pinus sp. in Armenia (ref. Chant \& YoshidaShaul 1987), and in Norway (Karg \& Edland 1987), the Netherlands and Germany (Chant \& Yoshida-Shaul 1987).

\section{Typhlodromus andrei Karg}

Fig. 16

Typhlodromus pritchardi Arutunjan (suspected synonym, Chant \& Yoshida-Shaul 1987).

Diagnosis: Idiosoma $376 \mu \mathrm{m}$. Dorsal shield lightly reticulated, with 4 pairs of distinct solenostomes plus smaller pores anteriorly and posteriorly to setae J2. Ventrianal shield with 4 pairs of preanal setae $(15 \mu \mathrm{m})$ and one pair of pores. Spermatheca cup-shaped, with sharp angular bottom. Movable digit of chelicerae has 2 teeth. Macrosetae $(52 \mu \mathrm{m})$ on basitarsus of leg IV. $-T$. andrei and T. pritchardi Arutunjan are considered as possible synonyms (Chant \& Yoshida-Shaul 1987), and this conception is adopted here.

Distribution and host plants: Found only in Elimäki $\left(60^{\circ} 44^{\prime} \mathrm{N}, 26^{\circ} 24^{\prime} \mathrm{E}\right)$ on Pterocarya rhoifolia. T. andrei has been recorded on bark of fruit trees in Belgium (Karg 1982), T. pritchardi on Fragaria sp., Pinus sp., Primula vulgaris and Prunus spinosa in Armenia and Yaroslavl, Russia (Moraes et al. 1986).

\section{Genus Phytoseiulus Evans}

\section{Phytoseiulus persimilis Athias-Henriot}

Fig. 17

Phytoseiulus riegeli Dosse, Chant; Amblyseius tardi Lombardini, Kennett \& Caltagirone.
Diagnosis: Idiosoma $340 \mu \mathrm{m}$, orange coloured. Dorsal shield smooth, without reticulation, weakly sclerotized, with 7 pairs of small but distinct pores. Setae are serrated except j1, z2, z5, S5 and J5. Ventrianal shield small, with no preanal setae. Spermatheca narrow, with a stricture. Movable digit of chelicerae has 1 tooth. Macrosetae $(116 \mu \mathrm{m})$ on basitarsus on leg IV.

Distribution and host plants: One specimen found in Paimio $\left(60^{\circ} 25^{\prime} \mathrm{N}, 22^{\circ} 42^{\prime} \mathrm{E}\right)$ on Malus domestica, obviously originating from a glasshouse. $P$. persimilis is used in glasshouses for the control of spider mites. It has been recorded on various trees, bushes and herbaceous plants in Mediterranean countries and South America (Moraes et al. 1986). The species has been introduced and is established in many countries. It probably cannot survive the Finnish climate, because of its temperature requirements (Kennett \& Caltagirone, 1968).

\section{Genus Proprioseiopsis Muma}

\section{Proprioseiopsis okanagensis (Chant)}

Fig. 18

Typhlodromus (Amblyseius) okanagensis Chant; Typhlodromus okanagensis levis Wainstein, Karg.

Diagnosis: Idiosoma $401 \mu \mathrm{m}(392-412)$. Dorsal shield smooth, without reticulation, weakly sclerotized, with 9 pairs of pores. Ventrianal shield reticulate, lightly sculptured, with 3 pairs of preanal setae and 1 pair of small, distinct pores. Spermatheca narrow bell-shaped, distinctly scleroticed. Movable digit of chelicerae has 1 tooth. Macrosetae on basitarsus $(61-64 \mu \mathrm{m})$, genu and tibia of leg IV.

Distribution and host plants: Found in Juva $\left(61^{\circ} 53^{\prime} \mathrm{N}, 26^{\circ} 51^{\prime} \mathrm{E}\right)$ on cultivated strawberry Fragaria $\times$ ananassa and in Åland $\left(60^{\circ} 15^{\prime} \mathrm{N}\right.$, $\left.19^{\circ} 58^{\prime} \mathrm{E}\right)$ on Ribes nigrum. $P$. okanagensis has been recorded on fruit trees, herbaceous plants and in litter and soil in North America and Europe (Moraes et al. 1986). 


\section{Genus Euseius Wainstein}

\section{Euseius finlandicus (Oudemans)}

Fig. 19

Seiulus finlandicus Oudemans; Typhlodromus (Amblyseius) finlandicus (Oudemans), Chant.

Diagnosis: Idiosoma $328 \mu \mathrm{m}$ (304-344). Dorsal shield pale, weakly sclerotized, faintly reticulated, with 4-6 pairs of pores. Ventrianal shield with 1 pair of distinct, crescentic pores and 3 pairs of preanal setae in anterior part of the shield. Spermatheca narrow, with a stricture in neck. Movable digit of chelicerae has 1 or 2 teeth. Macrosetae on basitarsus ( $53 \mu \mathrm{m}, 44-62)$ and shorter macrosetae on tibia and genu of leg IV.

Distribution and host plants: Common on deciduous trees and bushes; found on Acer platanoides, Aesculus hippocastani, Alnus incana, Amelanchier spicata, Aristolochia macrophylla, Betula lutea, Cornus alba, Corylus avellana, Crataegus coccinea, Fagus grandifolia, Fragaria vesca, Fraxinus excelsior, Juglans ailanthifolia, J. cinerea, J. mandshurica, Malus sp., Prunus avium, P. padus, Pterycaria rhoifolia, Pyrus communis, Quercus robur, Ribes nigrum, $R$. rubrum, $R$. uva-crispa, Rubus fruticosus, $R$. odoratus, Salix sp., S. caprea, Sorbus thuringiana, Tilia americana, T. cordata, Tilia $\times$ euchlora, Ulmus glabra, Viburnum opulus. E. finlandicus is the most widespread and abundant species in Finland. It has been recorded on numerous trees and bushes, less frequently on herbaceous plants, in all parts of the world. Only one report of the total of 123 references listed by Moraes et al. (1986) states that the species was found in litter, and there are no observations of the species in soil.

\section{Genus Amblyseius Berlese}

\section{Key to species}

1. Great differences in lengths of dorsal setae, $\mathrm{j} 3$ at least three times longer than $\mathrm{j} 4, \mathrm{j} 5$ and $\mathrm{z} 5$..........................

- j4, j5 and z5 normal, not much shorter than j3 ...........3
2. $\mathrm{Z} 4(89 \mu \mathrm{m}, 76-96)$ longer than $\mathrm{Z5}(68 \mu \mathrm{m}, 60-80)$, dorsal shield heavily sclerotized and reticulated, often brown coloured; spermatheca long, narrow v-shaped; ventrianal shield with one pair of pores .....subsolidus

- Z5 (71 $\mu \mathrm{m}, 68-72)$ longer than Z4 (52 $\mu \mathrm{m}, 50-53)$; dorsum not brown; spermatheca dish-shaped, strongly sclerotized with a prominent atrium; no pores on ventrianal shield. tenuis

3. $\mathrm{J} 2$ and $\mathrm{Zl}$ shorter than $\mathrm{S} 2$; spermatheca bell-shaped .4

- $\mathrm{J} 2$ and $\mathrm{Zl}$ about equal to $\mathrm{S} 2$; spermatheca not bellshaped......

4. Ventrianal shield with one pair of distinct 'eye-shaped' pores; ratio of Z4 (44 $\mu \mathrm{m}, 34-48)$ : S4 (28 $\mu \mathrm{m}, 19-32)$ $=1.5-1.6$; length of idiosoma under $360 \mu \mathrm{m}$ reductus

- Ventrianal shield with one pair of normal circular pores; length of $\mathrm{Z4}(38 \mu \mathrm{m})$ about equal to S4 (33 $\mu \mathrm{m})$; length of idiosoma over $360 \mu \mathrm{m}$......... cucumeris

5. Dorsal shield reticulated; spermatheca a wide v-shaped funnel with a neck ............................................ zwoelferi

- Dorsal shield without reticulation; spermatheca narrow, long tube-shaped. barkeri

\section{Amblyseius subsolidus (Beglyarov)}

Fig. 20

Typhlodromus subsolidus Beglyarov; Neoseiulus (Amblyseius) canadensis (Chant \& Hansell), Wainstein; Neoseiulus subsolidus (Beglyarov), according to Moraes et al. (1986); Typhlodromips subsolidus (Beglyarov), according to Karg (1991).

Diagnosis: Idiosoma $389 \mu \mathrm{m}$ (356-440). Dorsal shield heavily sclerotized and markedly reticulate, often brown-coloured, with 3-6 pairs of obscure pores. Setae Z5 serrated.

Ventrianal shield large, convex, about as long as wide, reticulate, with 1 pair of pores and 3 pairs of preanal setae. Spermatheca long, Vshaped. Movable digit of chelicerae has 2 prominent teeth. 3 short, barely differentiated macrosetae on basitarsus of leg IV, the longest one $27 \mu \mathrm{m}$ (20-30). - Dutch specimens of $A$. subsolidus have longer setae than Canadian specimens (Miedema 1987) and the same is also true of Finnish specimens.

Distribution and host plants: Found on Crataegus coccinea, Malus sp., Prunus padus. A. subsolidus has been recorded on trees and bushes in Leningrad and Yaroslavl regions in Russia, in Alaska and in Canada (Moraes et al. 1986). 


\section{Amblyseius tenuis (Hirschmann)}

Fig. 21

Typhlodromus tenuis Hirschmann; Typhlodromips (Typhlodromus) tenuis (Hirschmann), according to Moraes et al. (1986).

Diagnosis: Idiosoma $357 \mu \mathrm{m}$ (356-360). Dorsal shield smooth, with 4-5 pairs of obscure pores plus 1 pair of prominent pores anterior to setae S5. Setae Z5 and Z4 very faintly serrated. Ventrianal shield with 3 pairs of preanal setae. Spermatheca heavily sclerotized, with a distinct atrium. Movable digit of chelicerae has 2 teeth. Macrosetae (74 $\mu \mathrm{m}, 73-76)$ on basitarsus of leg IV. Shorter macrosetae on genu and tibia.

Distribution and host plants: Found in Finland only in Juva $\left(61^{\circ} 53^{\prime} \mathrm{N}, 26^{\circ} 51^{\prime} \mathrm{E}\right)$ on Fragaria $\times$ ananassa. Earlier records of $A$. tenuis are on 'burnt wood' in Germany and on Rubus sp. in Canada (Moraes et al. 1986) and, according to Karg (1991), in litter in central Europe.

\section{Amblyseius reductus Wainstein}

Fig. 22

Neoseiulus (Amblyseius) reductus (Wainstein), according to Moraes et al. (1986).

Diagnosis: Idiosoma $336 \mu \mathrm{m}$ (328-344). Dorsal shield lightly reticulated and sclerotized, with 3-5 pairs of distinct pores on dorsal shield. Setae Z5 slightly serrated. Ventrianal shield pentagonal, lightly reticulated, with 1 pair of slender 'eye-shaped' pores and 3 pairs of preanal setae. Spermatheca bell-shaped, twice as long as broad. Movable digit of chelicerae with 1 tooth. Macrosetae (45 $\mu \mathrm{m}, 40-56)$ on basitarsus of leg IV.

Distribution and host plants: Found in Finland on Aristolochia macrophylla, Fragaria vesca, Fragaria $\times$ ananassa, Malus sp., Ribes rubrum, Rubus idaeus, Tussilago farfara, and Ulmus glabra. A. reductus has been recorded on various trees, bushes and herbaceous plants in Eurasia (Moraes et al. 1986). It has been used in the biological control of mites on strawberry in Russia (Tokunova \& Malov 1988).

\section{Amblyseius cucumeris (Oudemans)}

Fig. 23

Typhlodromus cucumeris Oudemans; Neoseiulus (Typhlodromus) thripsi (MacGill), Evans; Amblyseius coprophilus Karg, Karg; Neoseiulus (Typhlodromus) cucumeris (Oudemans), according to Moraes et al. (1986).

Diagnosis: Idiosoma $375 \mu \mathrm{m}$ (370-380). Dorsal shield lightly reticulated, with 5 pairs of distinct pores. Setae Z5 faintly serrated. Ventrianal shield with 3 pairs of preanal setae and 1 pair of pores. Spermatheca narrow bell-shaped. Movable digit of chelicerae has 1 tooth. Macrosetae $(48 \mu \mathrm{m})$ on basitarsus on leg IV.

Distribution and host plants: Found outdoors only in Piikkiö $\left(60^{\circ} 23^{\prime} \mathrm{N}, 22^{\circ} 33^{\prime} \mathrm{E}\right)$ on Fragaria $\times$ ananassa (originating from earlier artificially introduced specimens). A. cucumeris is used in biological control of the onion thrips Thrips tabaci Lind. It has been recorded on various trees, bushes and herbaceous plants, e.g. on strawberries in Europe, North America and New Zealand (Moraes et al. 1986). Karg (1991) lists Phytonemus pallidus ssp. fragariae (Zimm.) among its prey species.

\section{Amblyseius zwoelferi (Dosse)}

Fig. 24

Typhlodromus zwölferi Dosse, 1957; Neoseiulus zeitunicus Wainstein \& Arutunjan, Wainstein; Neoseiulus (Typhlodromus) zwölferi (Dosse), according to Moraes et al. (1986).

Diagnosis: Idiosoma $418 \mu \mathrm{m}$ (408-440). Dorsal shield distinctly reticulated, often with pigmented areas present, and with 7 pairs of small pores. Setae Z5 slightly serrated. Ventrianal shield reticulated, with 3 pairs of preanal setae and $0-1$ pair of small pores. Spermatheca wide funnel-shaped without neck. Movable digit of chelicerae without teeth. Macrosetae on basitarsus (51 $\mu \mathrm{m}, 48-54)$, another much shorter macroseta on tibia of leg IV.

Distribution and host plants: Found in Åland $\left(60^{\circ} 15^{\prime} \mathrm{N}, 19^{\circ} 58^{\prime} \mathrm{E}\right)$ on Ribes nigrum and Fragaria $\times$ ananassa and in Mikkeli $\left(61^{\circ} 40^{\prime} \mathrm{N}, 27^{\circ} 12^{\prime} \mathrm{E}\right)$ on 
Fragaria $\times$ ananassa. A. zwoelferi has been recorded earlier mainly on herbaceous plants and fruit trees in Europe and North America (Moraes et al. 1986).

\section{Amblyseius barkeri (Hughes)}

Fig. 25

Neoseiulus barkeri Hughes; Amblyseius mckenziei Schuster \& Pritchard, Ragusa \& Athias-Henriot.

Diagnosis: Idiosoma $384 \mu \mathrm{m}$ (372-406). Dorsal shield slightly reticulated, with 4 pairs of distinct pores. Setae Z5 faintly serrated. Ventrianal shield indistinctly striated, with 1 pair of distinct pores and 3 pairs of preanal setae. Spermatheca tube-shaped, atrium heavily sclerotized. Movable digit of chelicerae has 1 tooth. Macrosetae $(70 \mu \mathrm{m}, 66-74)$ on basitarsus of leg IV.

Distribution and host plants: Only in glasshouses where A. barkeri is used for the biological control of thrips. A. barkeri has been recorded on various trees, bushes and herbaceous plants in Europe and Asia (Moraes et al. 1986).

Acknowledgements. For the identification and confirmation of many specimens of Phytoseiidae, I want to thank Mrs. Eiko Shaul and Dr. D. A. Chant (University of Toronto, Canada). I am much indebted to Dr. T. Edland (Norwegian Plant Protection Institute, Norway), who provided me with specimens of Phytoseiidae collected in Norway. I want to express my gratitude to Prof. D. Kropczynska, who has guided me in the working methods and systematics of Phytoseiidae.

\section{References}

Athias-Henriot, C. 1960: Nouveaux Amblyseius d'Algerie (Parasitiformes, Phytoseiidae). - Acarologia 2:288299.

Beglyarov, G. A. (Беглыаров, Г. А.) 1981: Keys to the determination of phytoseiid mites of the U.S.S.R. (In Russian) - Information Bulletin IOBC EPS. No 2, Vol. 1 and 2. 95 and 47 pp.

Chant, D. A. 1957: Descriptions of some phytoseiid mites (Acarina: Phytoseiidae). Part I: Nine new species from British Columbia with keys to the species of British Columbia. Part II. Redescriptions of eight species described by Berlese. - Can. Entomol. 89:289-308.

- 1959: Phytoseiid Mites (Acarina: Phytoseiidae. Part I: Bionomics of seven species in Southeastern England. Part II:A taxonomic review of the family Phytoseiidae, with descriptions of 38 new species. - Can. Entomol. 41, Suppl. 12. 164 pp.

- 1965: The identity and distribution of species of Phytoseius Ribaga in Canada. - Can. Entomol. 97:897-909.

- 1985: The Phytoseiidae. External anatomy. — In: Helle, W. \& Sabelis, M. W. (eds.), Spider mites. Their biology, natural enemies and control. World Crop Pests 1B:516.

Chant, D. A. \& Hansell, R. I. C. 1971: The genus Amblyseius (Acarina: Phytoseiidae) in Canada and Alaska. — Can. J. Zool. 49:703-758.

Chant, D. A. \& Yoshida-Shaul, E. 1982: A world review of the soleiger species group in the genus Typhlodromus Scheuten (Acarina: Phytoseiidae). - Can. J. Zool. 60:3021-3032.

- 1986: The subfamily Chantiinae in the family Phytoseiidae (Acari: Gamasina), — Can. J. Zool. 64:2024 2034.

- 1987: A world review of the pyri species group in the genus Typhlodromus Scheuten (Acari: Phytoseiidae). - Can. J. Zool. 65:1770-1804.

- 1989: Adult dorsal setal patterns in the family Phytoseiidae (Acari: Gamasina). — Int. J. Acarol. 15:219 233.

Denmark, H. A. \& Rather, A. O. 1984: Revision of the genus Typhloctonus Muma, 1961 (Acarina: Mesostigmata). - Int. J. Acarol. 10:163-177.

Dosse, G. 1956: Über die Entwicklung einiger Raubmilben bei verschiedenen Nahrungstieren (Acar., Phytoseiidae). - Pflanzenschutzberichte 16:122-136.

- 1958: Die Spermathecae, ein zusätzliches Bestimmungsmerkmal bei Raubmilben. (Acar., Phytoseiidae). - Pflanzenschutz-Berichte 21:44-61.

Edland, T. 1987: Rovmiddar (Phytoseiidae) på frilandsvekstar i Norge. [Predacious mites (Phytoseiidae) on field-grown plants in Norway.] - Entomol. Tidskr. 108:21-22.

Evans, G. O. 1987: Mesostigmata. Observations on the descriptive morphology and classification of the Phytoseiidae. - In: Evans, G. O. \& Murphy, P. W. (eds.), The Acari. A practical manual. I. Morphology, systematics of the subclass and classification of the mesostigmata: 153-166. - University of Nottingham, School of Agriculture. Sutton Bonington, Leics.

Hansen, E. W. \& Johnsen, S. 1986: Rovmider av familien Phytoseiidae i Danmark (Acarina, Gamasina). [Predacious mites in the family Phytoseiidae in Denmark (Acarina, Gamasina.] — Entomol. Meddelel. 53:137142. (In Danish)

Helle, W. \& Sabelis, M. W. (eds.) 1985: Spider mites. Their biology, natural enemies and control. World crop pests IB. - Elsevier B.V., Amsterdam. 458 pp.

Karg, W. 1970: Neue arten der Raubmilbenfamilie Phytoseiidae Berlese 1916. - Deutsche Entomol. Zeitschr. 17:289-301.

- 1971: Die freilebenden Gamasina (Gamasides), Raubmilben. - In: Die Tierwelt Deutschlands und 
der angrenzenden Meeresteile nach ihren Merkmalen und nach ihre Lebensweise. 59. VEB Gustav Fischer Verlag, Jena. 475 pp.

- 1982: Diagnostik und Systematik der Raubmilben aus der Familie Phytoseiidae Berlese in Obstanlagen. Zool. Jahrb. Syst. 109:188-210.

- 1983: Systematische Untersuchung der Gattungen der Raubmilbenfamilie Phytoseiidae Berlese 1916 mit der Beschreibung von 8 neuen Arten. - Mitt. Zool. Mus. Berlin 59:293-328.

- 1991: Die Raubmilbenarten de Phytoseiidae Berlese (Acarina) Mitteleuropas sowie angrenzender Gebiete. —Zool. Jahrb. Syst. 118:1-64.

Karg, W. \& Edland, T. 1987: Neue Raubmilbenarten der Phytoseiidae Berlese, 1916. — Deutsche Entomol. Zeitschr., N. F. 34:387-395.

Kennett, C. E. \& Caltagirone, L. E. 1968: Biosystematics of Phytoseiulus persimilis Athias-Henriot (Acarina: Phytoseiidae). - Acarologia 10:563-577.

Kolodochka, L. А. (Колодоцхка, Л. А.) 1980: New species of phytoseiid mites from the fauna of USSR (Parasitiformes: Phytoseiidae). (In Russian), — Vestnik Zool. 2:64-70.

Kropczynska, D. \& Tuovinen, T. 1987: Predatory mites (Acari: Phytoseiidae) occurring on apple-trees in Finland. - Entomol. Tidskr. 108:31-32.

- 1988: Occurrence of predatory mites (Acari: Phyto- seiidae) on apple trees in Finland. - Ann. Agric. Fennicae 27:305-314.

Listo, J., Listo, E.-M. \& Kanervo, V. 1939: Studies of the fruit tree red mite (Paratetranychus pilosus C. \& F.). (In Finnish, English summary) - Valt. Maatalouskoet. Julk. 99:1-143.

Miedema, E. 1987: Survey of phytoseiid mites (Acari: Phytoseiidae) in orchards and surrounding vegetation of northwestern Europe, especially the Netherlands. Keys, descriptions and figures. - Neth. J. Plant Pathol. 93, Suppl. 2:1-64.

Moraes, G. I., McMurtry, J. A. \& Denmark, H. A. 1986: A catalog of the mite family Phytoseiidae. References to taxonomy, synonymy, distribution and habitat. Empresa Brasileira de Pesquisa Agropecuaria. Departamento Difusao de tecnologia, Brasilia DF. 353 pp.

Oudemans, A. C. 1915: Acarologische Aanteekeningen LVI. - Entomol. Berichten 4:180-188.

Rowell, H. J., Chant, D. A. \& Hansell, R. I. C. 1978: The determination of setal homologies and setal patterns on the dorsal shield in the family Phytoseiidae. Can. Entomol. 110:859-876.

Tokunova, M. V. \& Malov, N. A. (Токунова, M. B. \& Малов, Н. А.) 1988: Biological methods of pest control in strawberry. (In Russian) - Zaschita Rastenij 5:37-38.

Received 5.II.1992

Fig. 3-25. Species of Phytoseiidae. - Females: spermatheca, ventrianal area, dorsal shield (scale bar for dorsal shield, $100 \mu \mathrm{m})$. 

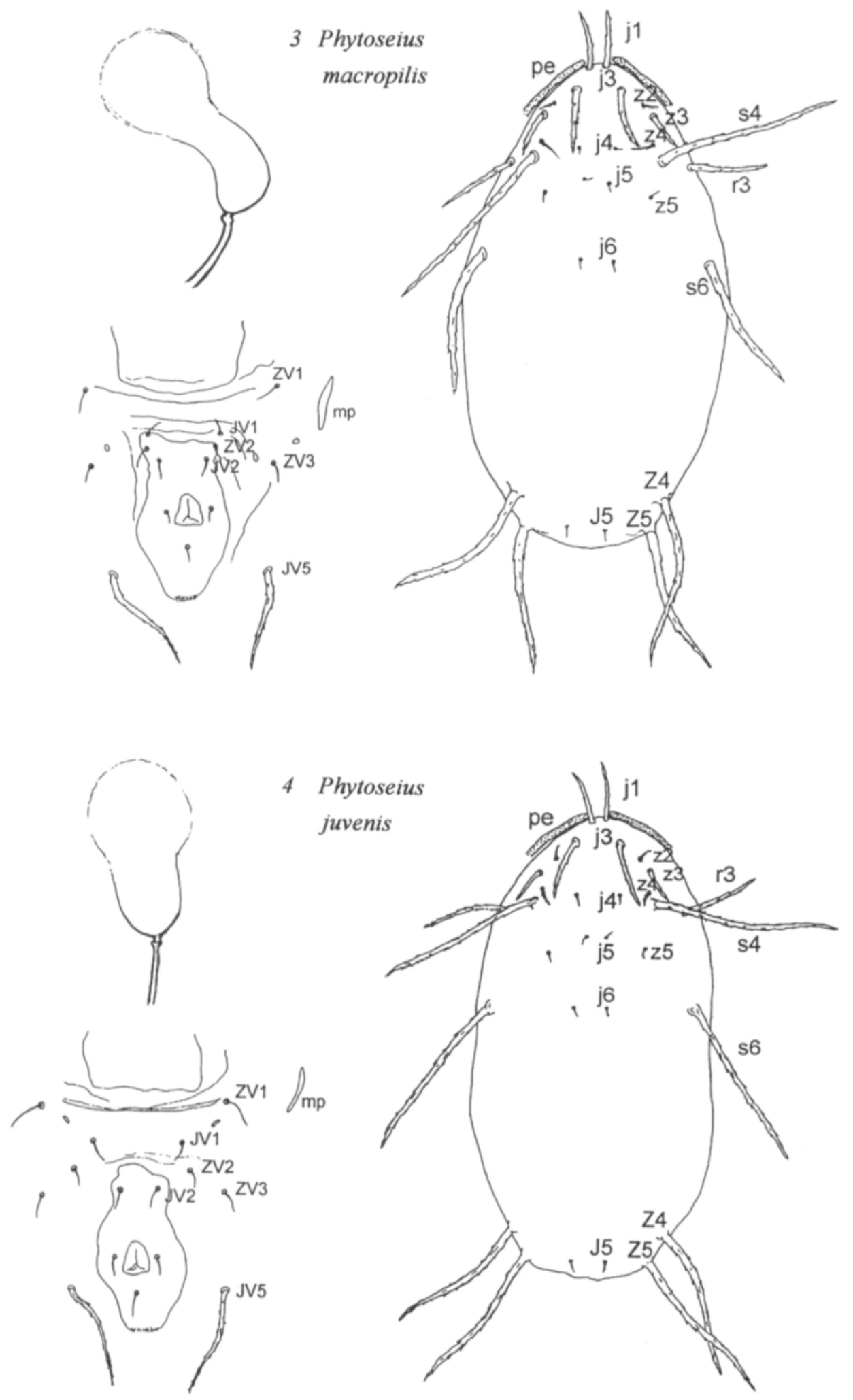

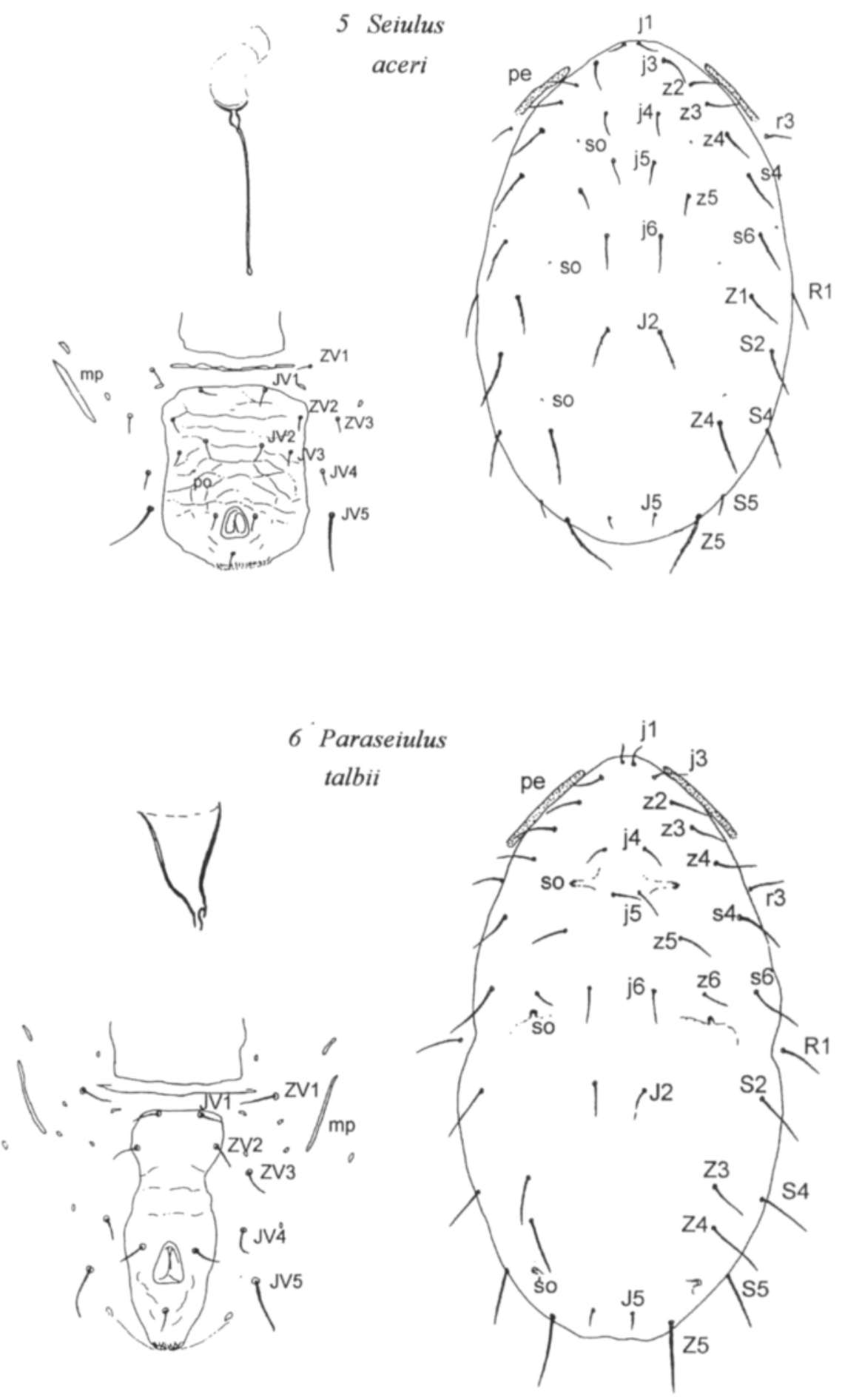

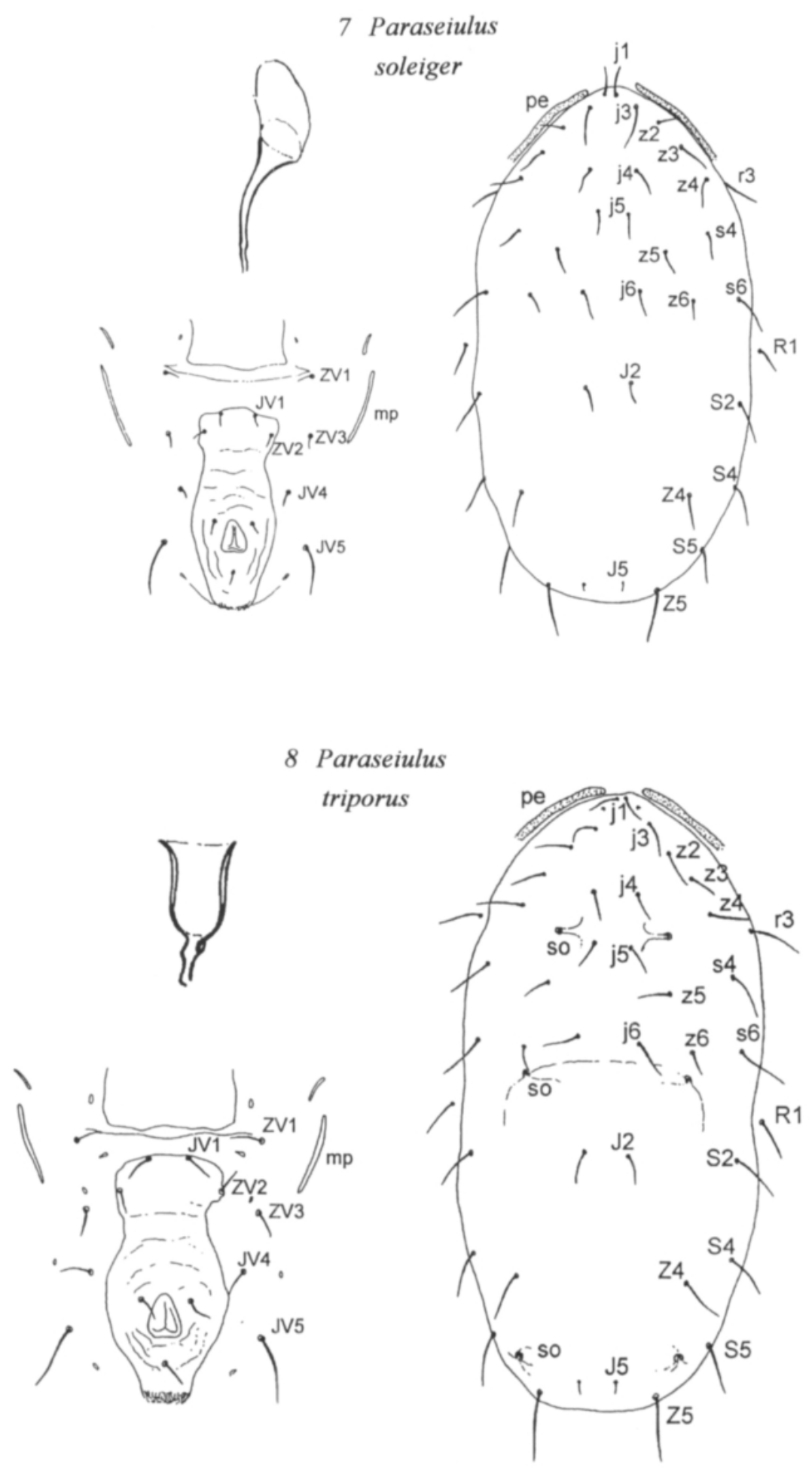

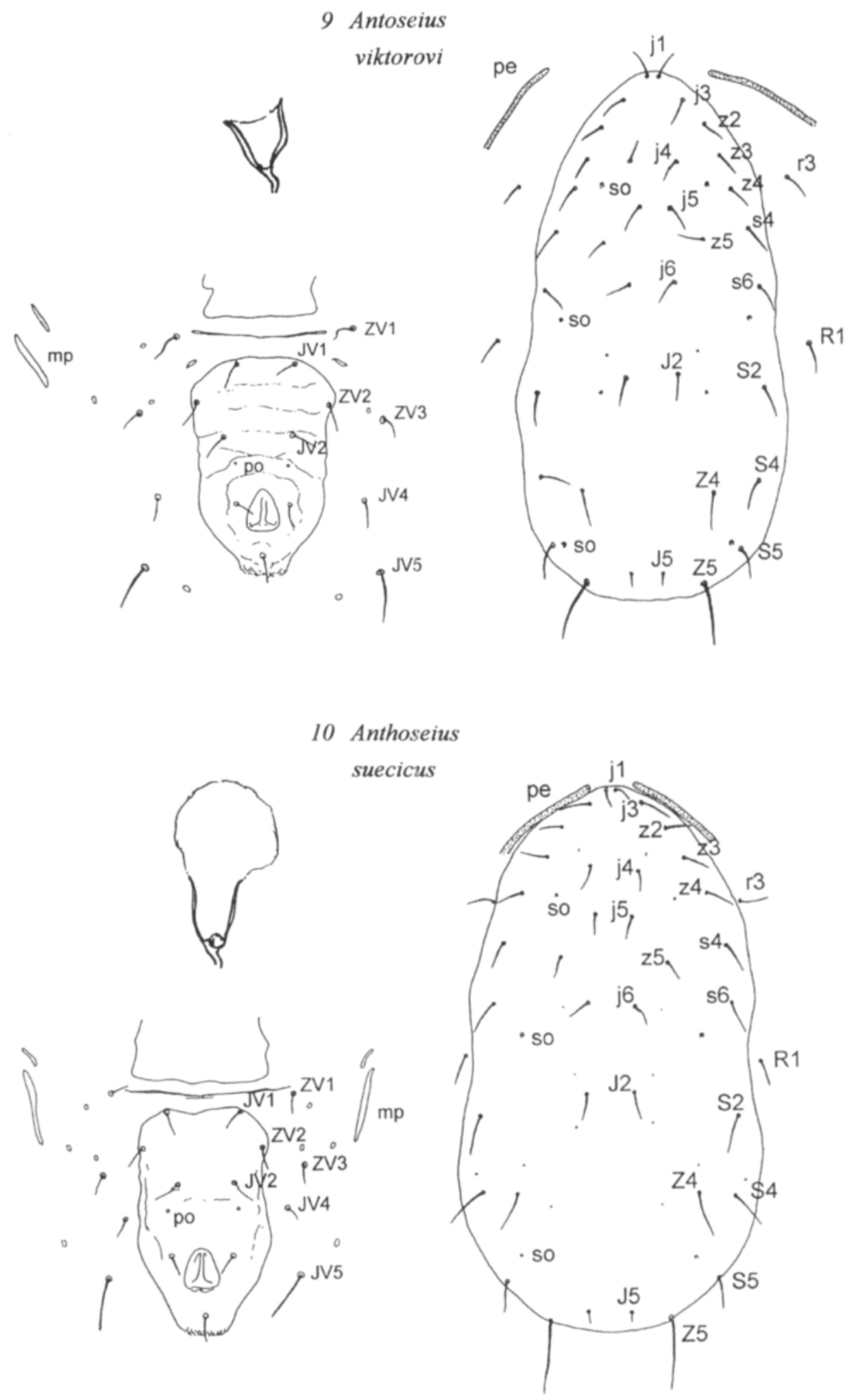


\section{Anthoseius}
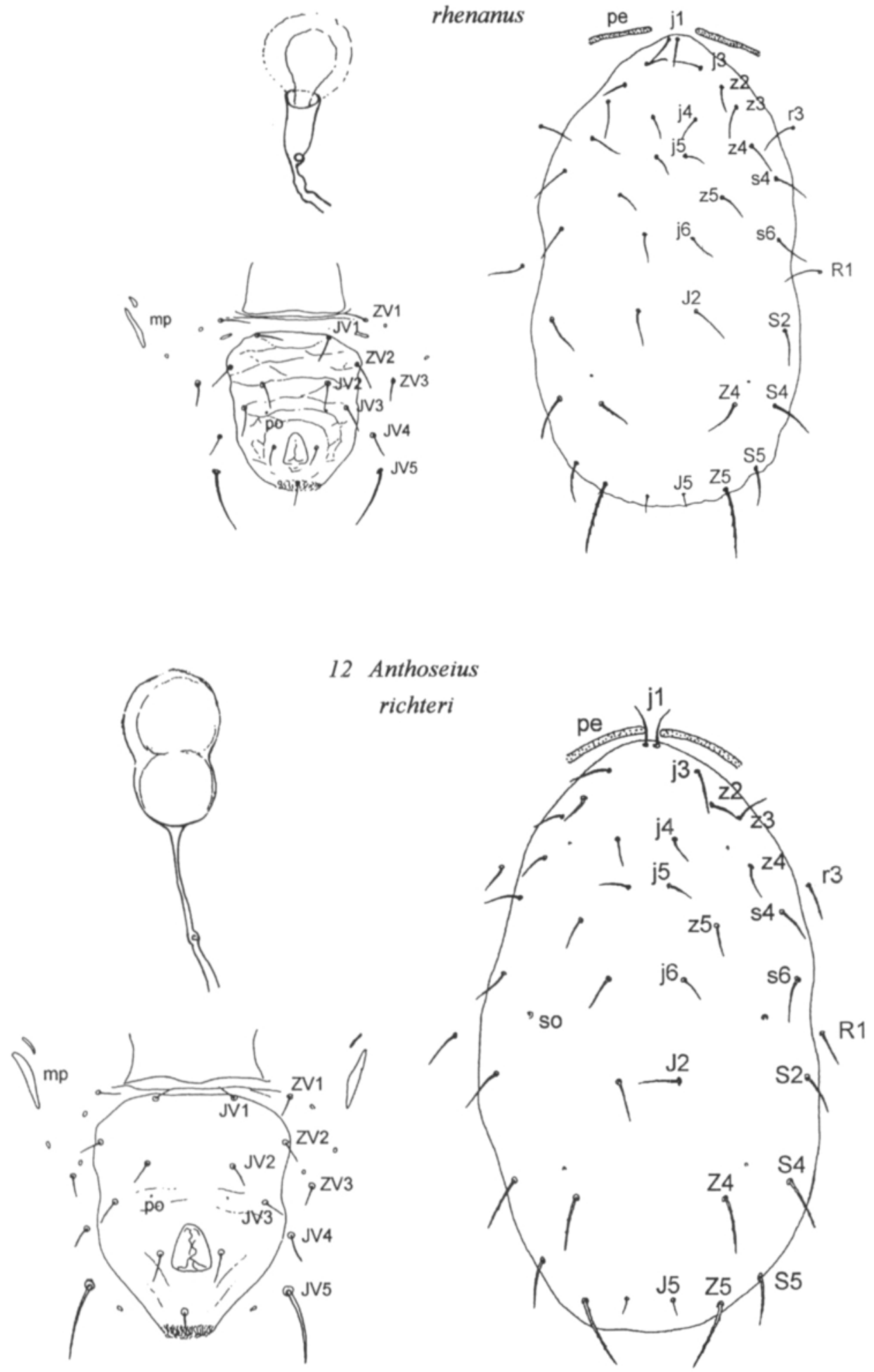

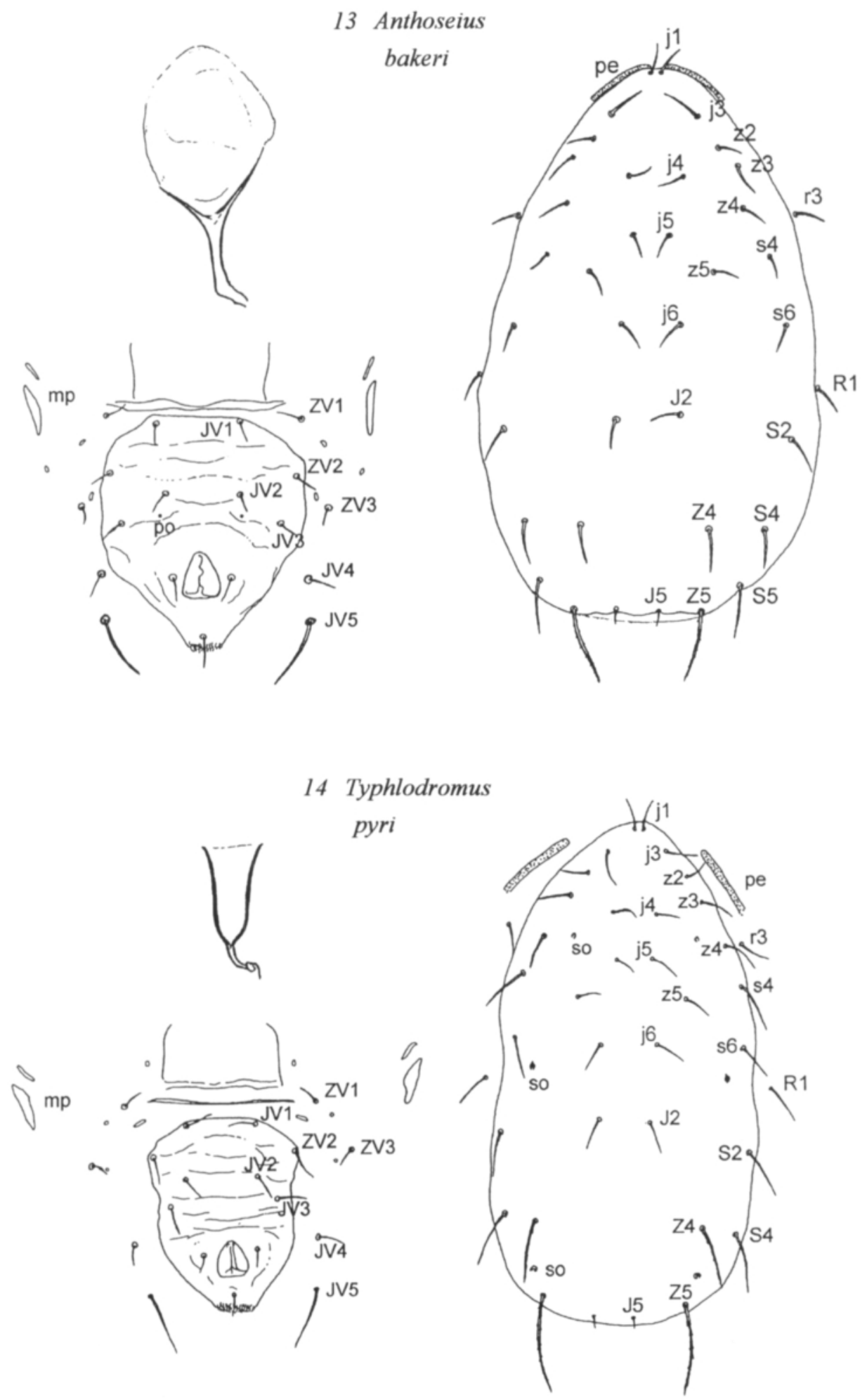

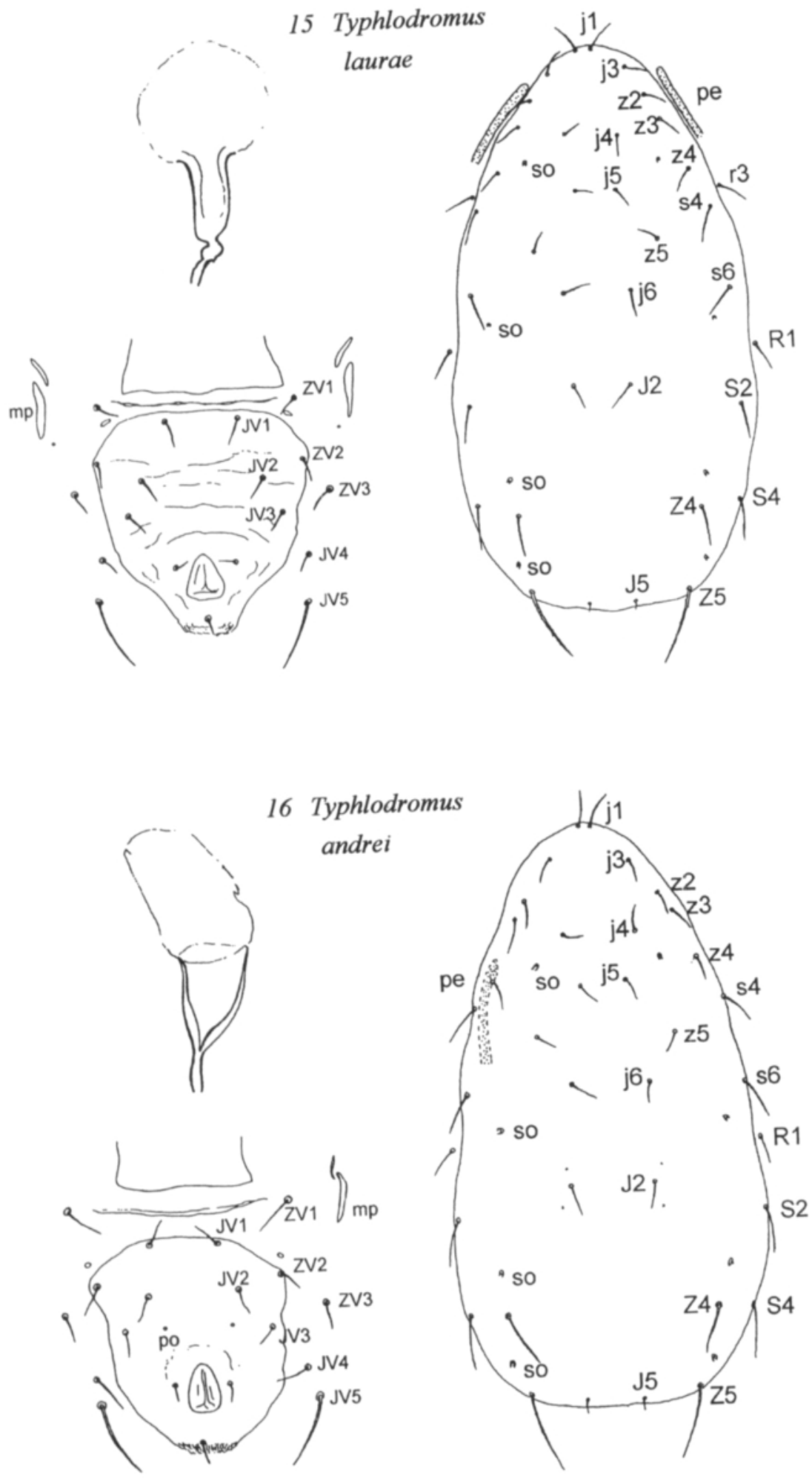

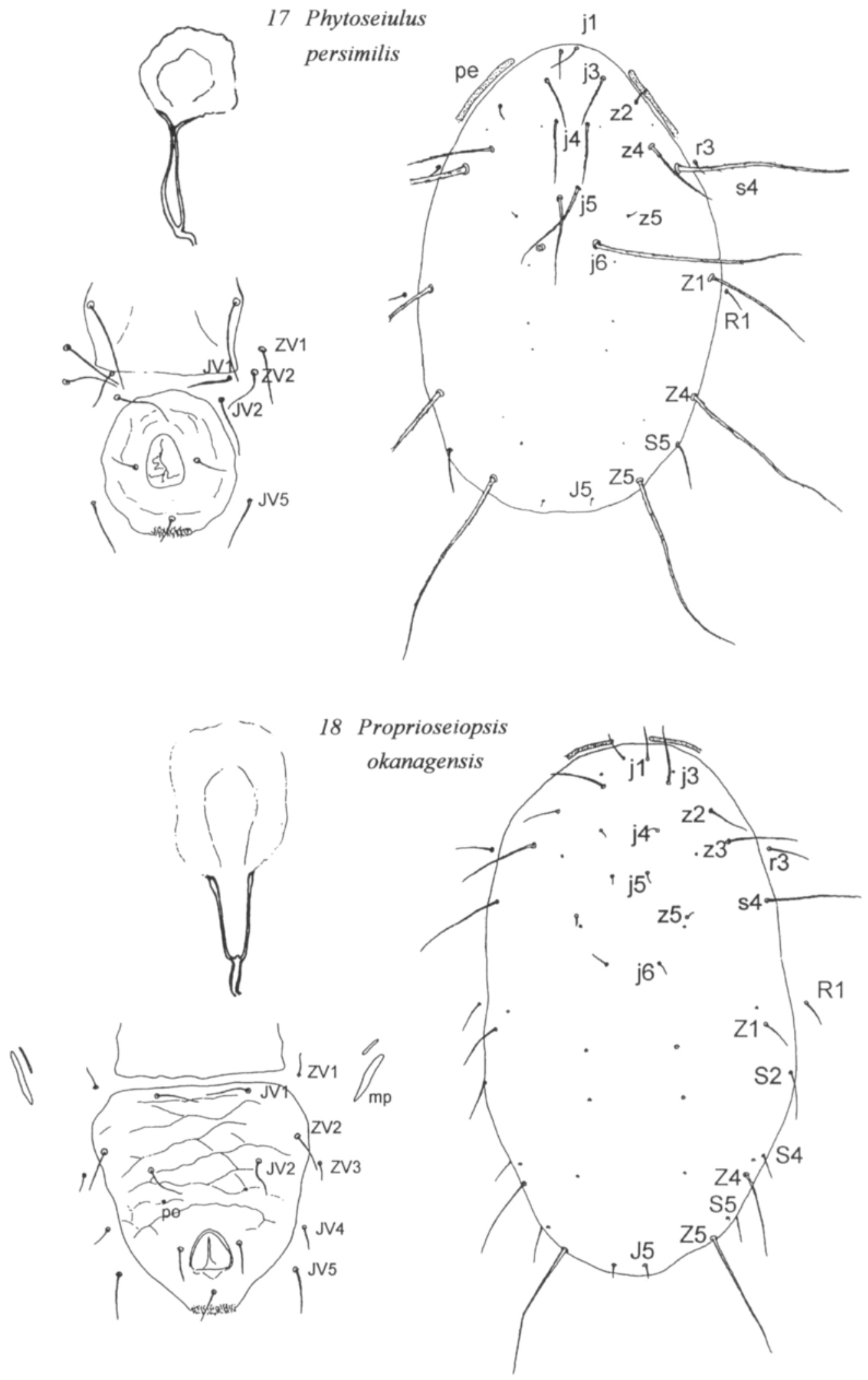


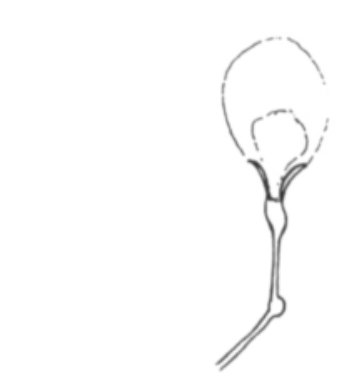

19 Euseius

finlandicus
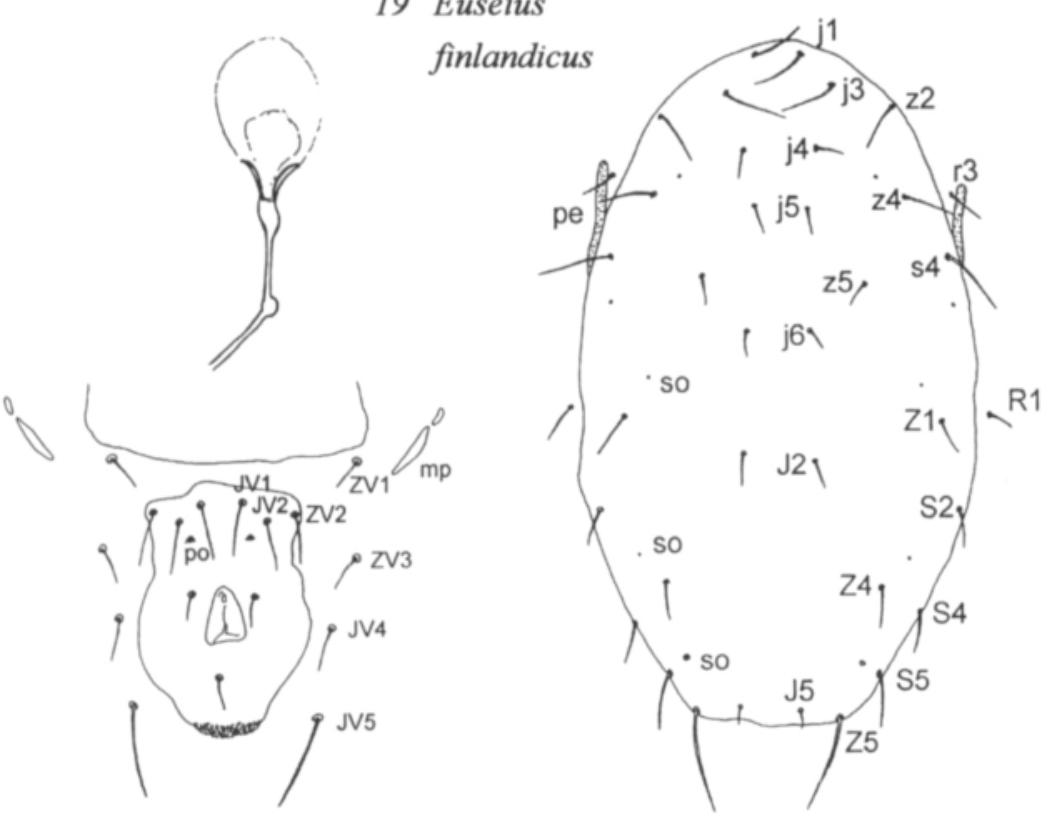

20 Amblyseius

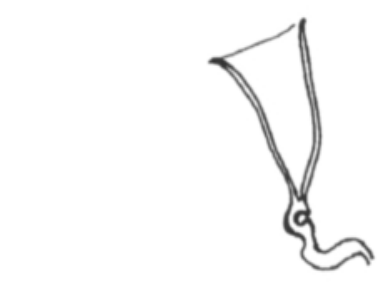

subsolidus

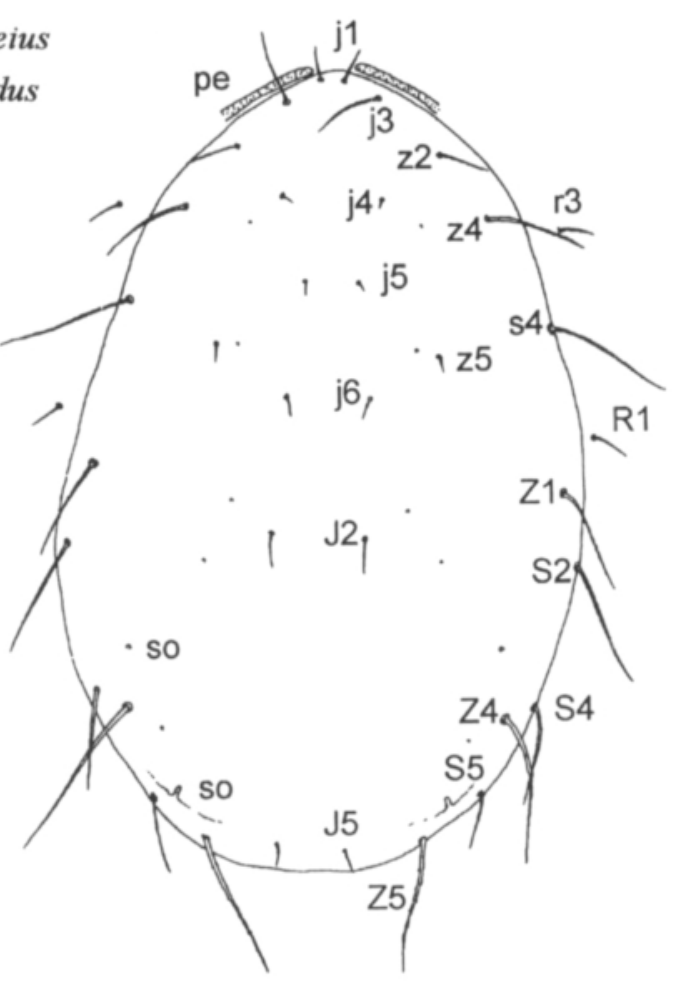



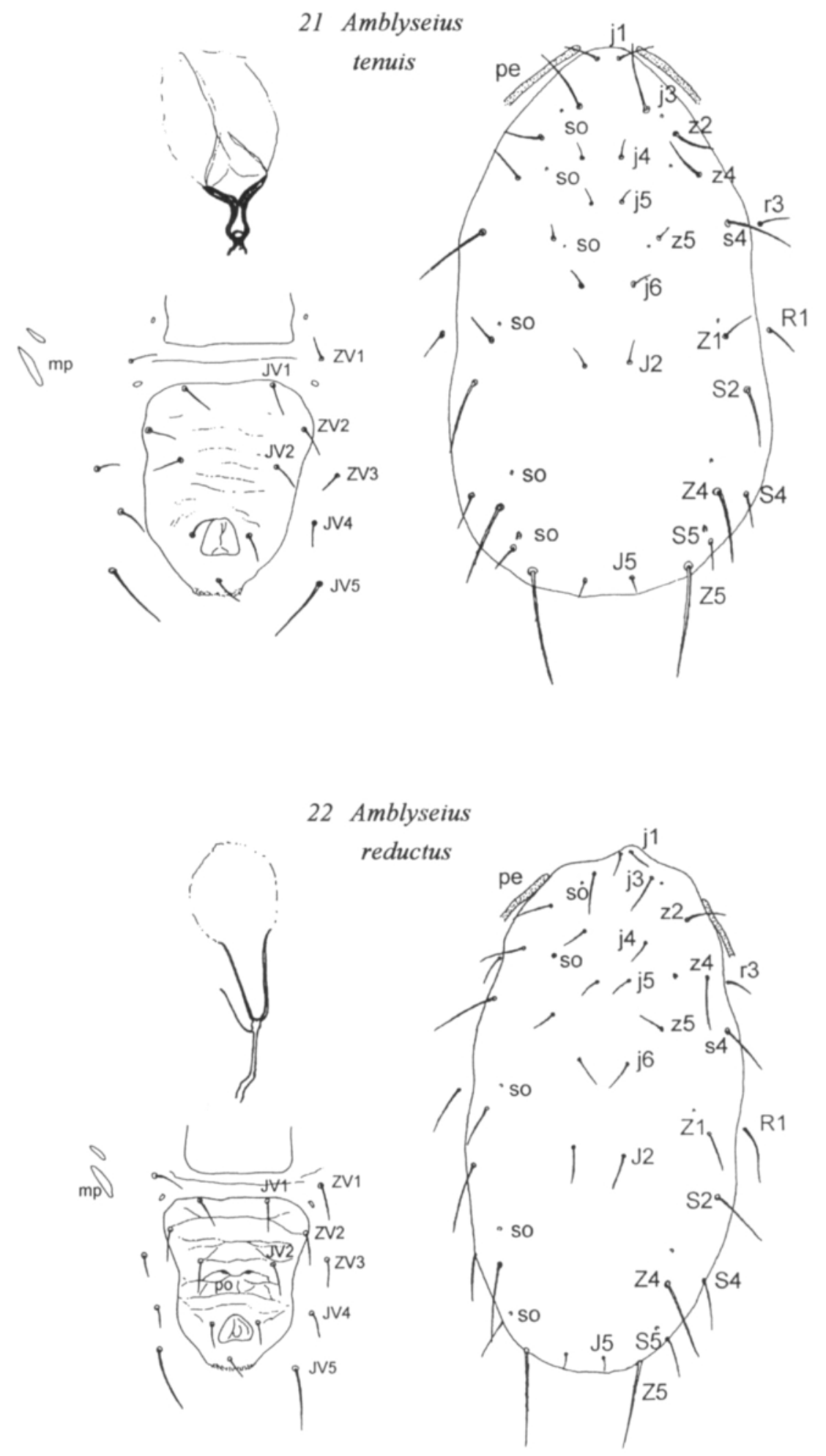

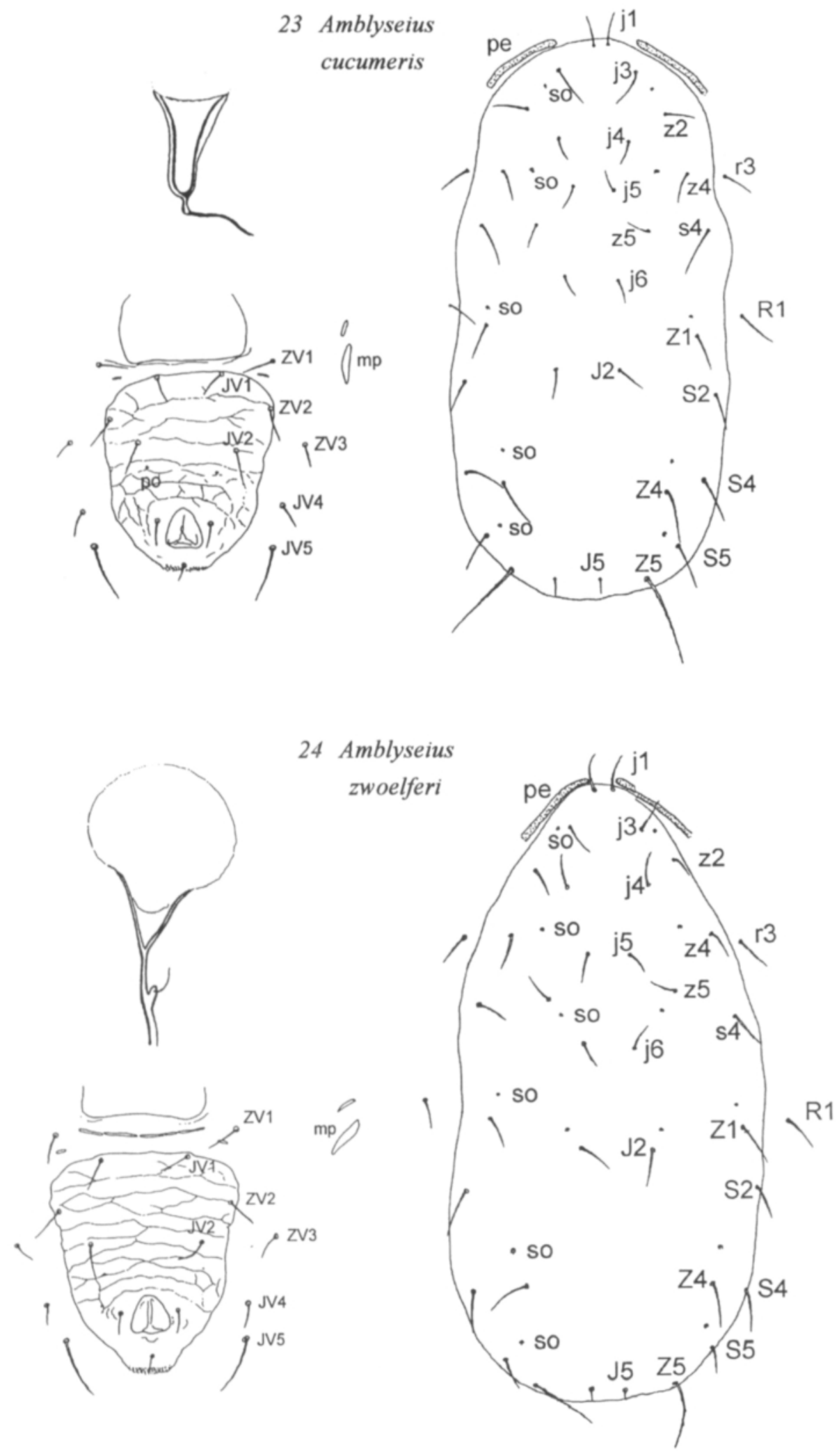


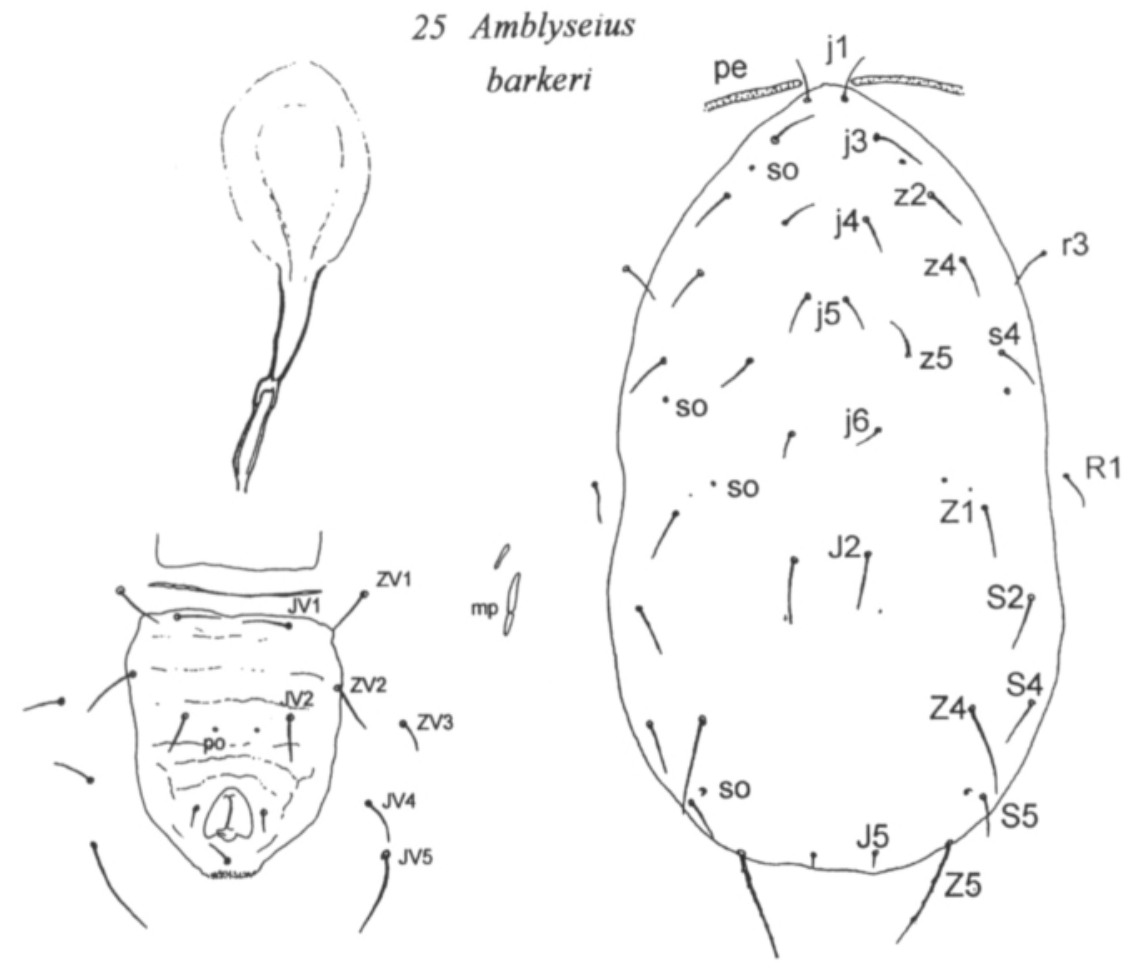




\title{
Phytoseiid mites (Acari: Phytoseiidae) on apple trees and in surrounding vegetation in southern Finland. Densities and species composition
}

\author{
T. Tuovinen ${ }^{\mathrm{a}}$ and J.A.H. Rokx ${ }^{\mathrm{b}}$ \\ anstitute of Plant Protection, Agricultural Research Centre, SF-31600 Jokioinen, Finland

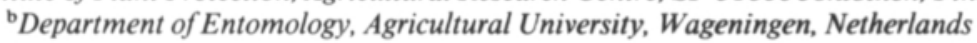

(Accepted 18 January 1991)

\begin{abstract}
Tuovinen, T. and Rokx, J.A.H., 1991. Phytoseiid mites (Acari: Phytoseiidae) on apple trees and in surrounding vegetation in southern Finland. Densities and composition of species. Exp. Appl. Acarol., 12: 35-46.
\end{abstract}

Leaf samples were collected from sprayed $(n=29)$ and unsprayed $(n=19)$ apple orchards, from the surrounding vegetation $(n=58)$ and from one arboretum $(n=12)$, altogether from 46 plant species (1-5 samples each). The density of phytoseiid mites averaged $1.2 \mathrm{mites} / \mathrm{leaf}$ on unsprayed apple trees, but only 0.06 mites/leaf on sprayed trees. The phytoseiid density exceeded 1 /leaf on Aesculus hippocastani, Aristolochia macrophylla, Corylus avellana, Fragaria vesca, Fraxinus excelsior, Juglans cinerea, Pterocarya rhoifolia, Ribes nigrum, Rubus odoratus, Sorbus aucuparia, S. thuringiaca, Tilia $\times$ euchlora and Ulmus glabra. Other common trees and bushes inhabited by phytoseiids were Crataegus coccinea (0.2 mites/leaf), Prunus padus (0.7), Salix caprea (0.4), and Tilia cordata (0.9).

Twelve species of phytoseiid mites were found, of which ten occurred on unsprayed apple trees. The most widely distributed species on apple trees were Phytoseius macropilis (in $79 \%$ of unsprayed samples), Euseius finlandicus (74\%), Paraseiulus soleiger (53\%), Paraseiulus triporus (37\%), Amblyseius canadensis ( $26 \%$ ) and Anthoseius rhenanus $(26 \%)$. The highest densities on apple trees were found in populations of $E$. finlandicus (mean 0.7 mites/leaf), Ph. macropilis ( 0.5$)$ and $A$. canadensis (0.5). On sprayed apple trees, E. finlandicus, $\mathrm{Pa}$. soleiger and $\mathrm{Ph}$. macropilis occurred most commonly, but their mean densities were under 0.1 / leaf. Almost no phytoseiids were found in orchards sprayed with oxydemetonmethyl before blooming of apple.

On other plants, E. finlandicus occurred most commonly (on 33 plant species) and in the highest densities, followed by $\mathrm{Ph}$. macropilis (14), Pa. soleiger (12), Pa. triporus (12) and An. rhenanus (7). Seiulus aceri and Paraseiulus talbii were identified as new phytoseiid species in Finland. It is concluded that deciduous trees and bushes in forest margins around orchards can serve as important reservoirs for phytoseiid mites, and that the dominant species in these plants would migrate into and colonize the orchards if the use of harmful chemicals were restricted.

\section{INTRODUCTION}

Phytoseiid mites (Acari: Phytoseiidae) are important predators of the European red spider mite Panonychus ulmi (Koch) (Acari: Tetranychidae) on 
unsprayed apple trees in Finland (Kropczynska and Tuovinen, 1987, 1988). Surveys conducted in apple orchards in many countries have demonstrated that phytoseiids can keep spider mite densities below economic thresholds (Dosse, 1960; Collyer, 1964; Wildbolz, 1986). The use of phytoseiids to control spider mites in orchards is also well documented (Croft and Barnes, 1971; McMurtry and van de Vrie, 1973; Hoy, 1982). In many cases, the introduced phytoseiid mites are conserved by using selective pesticides.

In Europe, the predatory mite species most commonly used in integrated pest management (IPM) programs is Typhlodromus pyri (Scheuten). This species occurs generally and has strains resistant to organophosphorous insecticides (OPs; Hoyt, 1972; Overmeer and van Zon, 1983). Typhlodromus pyri is capable of maintaining spider mite populations under economic thresholds in commercial orchards (Wildbolz, 1986). Typhlodromus pyri has not been found in Finland, but other phytoseiids have been detected on sprayed apple trees in very low numbers (Kropczynska and Tuovinen, 1988).

In the Nordic countries, phytoseiid mites occur on many deciduous trees and bushes (Hansen and Johnsen, 1986; Edland, 1987). These plants may serve as reservoirs for phytoseiid mites, allowing them to migrate into the orchard if harmful pesticides are not used. In Switzerland, Boller et al. (1988) studied mite samples from hedges and forests near vineyards and found $T$. pyri on some of the trees and bushes. They concluded that hedges are important reservoirs of $T$. pyri in areas where pesticides are regularly applied. Our preliminary observations of phytoseiids on different plants showed that the plant itself may have characteristics affecting phytoseiid mite populations. Therefore we conducted a more thorough study of the phytoseiids on various species of trees and bushes.

The trees most often used in windbreak hedges in Finland are alders (Alnus spp.) and spruce (Picea abies), although the natural vegetation usually supplies enough protection from strong wind. Common deciduous trees are birches (Betula pendula and B. pubescens), alders (Alnus glutinosa and A. incana), great sallow (Salix caprea), mountain ash (Sorbus aucuparia), bird cherry (Prunus padus) and aspen (Populus tremula). Bushes such as willow (Salix sp.), hawthorn (Crataegus coccinea), raspberry (Rubus idaeus), hazel (Corylus avellana) and elder (Sambucus racemosa) are also common near orchards. As well as the above, there are often various planted trees and bushes of foreign origin.

This study presents the results of a survey on the phytoseiid mites occurring in apple orchards and on nearby plants. The aim of the study was to evaluate the importance of surrounding vegetation as a reservoir and possible source of phytoseiid mites, especially the species that occur frequently on apple trees, and to establish if the phytoseiid mite species on apple tree show any resistance to commonly applied insecticides. 


\section{MATERIALS AND METHODS}

Most of the leaf samples were collected from commercial orchards and their surroundings in southern Finland and on the Åland Islands in August and September, 1989. The standard sample size was 100 leaves, with the exception of some broadleaf samples, which consisted of 10-50 leaves (Table 1). For each sample, the leaves were taken from 10-20 sprayed apple trees in commercial orchards, from single or a few unsprayed trees in home gardens, and from several specimens of various deciduous trees or bushes near the orchards. A special survey was made in the Mustila arboretum (Elimäki, $60^{\circ} 44^{\prime} \mathrm{N}, 26^{\circ} 24^{\prime} \mathrm{E}$ ), where many unusual plant species are grown. The number of samples other than those of apple was restricted to a maximum of five. In order to find the most suitable host plants for phytoseiid mites, samples were taken from a range of plant species.

The samples were either stored for a few days at $+6-8^{\circ} \mathrm{C}$ or they were handled immediately. First, a subsample of 5-10 leaves was examined under a stereomicroscope to check for the presence of eriophyid mites (Acari: Eriophyidae), an important food of many phytoseiid species. The leaves were then soaked in warm soapy water $\left(+70^{\circ} \mathrm{C}, 0.5 \%\right.$ Taski profi soap $)$ to remove and kill the mites on the leaves. After $24 \mathrm{~h}$ the samples were passed through 1 -mm and $0.1 \mathrm{~mm}$-mesh sieves. The phytoseiid mites were counted and collected into small tubes, and stored in $70 \%$ alcohol until preparation and identification. The mites were identified using the keys of $\operatorname{Karg}(1971,1982,1983)$ and Miedema (1987), the reference collection provided by T. Edland (1988, The Norwegian Plant Protection Institute), and the collection of Kropczynska and Tuovinen (1988).

\section{RESULTS}

The occurrence of phytoseiid mites and the presence of a common food source for phytoseiids, eriophyid mites, on apple trees and 46 other plants are presented in Table 1.

The highest phytoseiid densities were found in single samples on horse chestnut (Aesculus hippocastani; max. 14.4/leaf), blackcurrant (Ribes nigrum; 4.7), ash (Fraxinus excelsior, 3.8), mountain ash (3.3), hazel (3.3), Dutchman's pipe (Aristolochia macrophylla; 3.0), apple, unsprayed, cv. Harlamowska (2.8), purple raspberry (Rubus odoratus; 2.7 ), forest strawberry (Fragaria vesca; 2.4$)$, lime (Tilia $\times$ euchlora $; 2.3)$ and Pterocarya rhoifolia (2.3). Because the leaves of plants differ markedly in size, the values in Table 1 and above do not refer to the real density.

In this survey, twelve phytoseiid species were identified, ten on unsprayed apple trees, six on sprayed apple trees and eleven on various plants (Table 2 ). The most widely distributed phytoseiid species on unsprayed apple trees 
TABLE 1

Occurrence of phytoseiid and eriophyid mites in samples ${ }^{\mathrm{a}}$ collected from apple orchards and nearby plants

\begin{tabular}{|c|c|c|c|}
\hline Plant species & Samples (n) & Phytoseiids/sample & Eriophyids $^{\mathrm{b}}$ \\
\hline \multicolumn{4}{|l|}{ Deciduous trees } \\
\hline Malus domestica (sprayed) & 29 & 5.5 & +++ \\
\hline M. domestica (unsprayed) & 19 & 116.8 & + \\
\hline Acer platanoides & 3 & 21.0 & - \\
\hline Aesculus hippocastani (15) & 2 & 118.5 & - \\
\hline Alnus glutinosa & 2 & 1.0 & ++ \\
\hline A. incana & 1 & 2 & ++ \\
\hline Betula pendula & 2 & 0.0 & - \\
\hline B. lutea $\mathbf{M}^{c}$ & 1 & 40 & - \\
\hline Fagus grandifolia $\mathbf{M}$ & 1 & 8 & - \\
\hline Fraxinus excelsior ( 50 ) & 2 & 98.5 & +++ \\
\hline Prunus padus & 3 & 67.3 & - \\
\hline P. cerasus & 2 & 3.5 & - \\
\hline P. avium & 2 & 0.0 & - \\
\hline Pyrus communis & 1 & 1 & - \\
\hline Salix caprea & 1 & 35 & - \\
\hline Sorbus aucuparia & 2 & 170.5 & + \\
\hline S. aucuparia $\times$ intermedia & 1 & 0 & - \\
\hline S. thuringiaca & 1 & 111 & - \\
\hline Tilia americana $\mathrm{M}$ & 1 & 27 & - \\
\hline T. cordata & 2 & 88.0 & - \\
\hline T. euchlora $\mathrm{M}$ & 1 & 228 & - \\
\hline Ulmus glabra & 2 & 115.0 & + \\
\hline \multicolumn{4}{|l|}{ Deciduous bushes } \\
\hline Amelanchier spicata $\mathrm{M}$ & 1 & 2 & - \\
\hline Aristolochia macrophylla M (30) & 1 & 89 & - \\
\hline Betula nana & 1 & 0 & + \\
\hline Cornus alba & 1 & 77 & - \\
\hline Corylus avellana & 5 & 167.6 & + \\
\hline Crataegus coccinea & 3 & 21.0 & - \\
\hline Juglans ailanthifolia M (10) & 1 & 9 & - \\
\hline J. cinerea M (10) & 1 & 15 & - \\
\hline J. mandschurica M (10) & 1 & 6 & - \\
\hline Philadelphus sp. M & 1 & 6 & - \\
\hline Pterocarya rhoifolia M (30) & 1 & 68 & - \\
\hline Ribes nigrum & 2 & 237.0 & - \\
\hline R. rubrum & 2 & 11.0 & - \\
\hline R. uva-crispa & 1 & 4 & - \\
\hline Rosa sp. & 1 & 1 & - \\
\hline Rubus fruticosus & 1 & 3 & - \\
\hline R. idaeus & 3 & 5.0 & + \\
\hline R. odoratus (40) & 1 & 109 & - \\
\hline Salix fragilis $(150)$ & 1 & 0 & - \\
\hline Salix sp. & 1 & 1 & - \\
\hline Sambucus racemosa & 1 & 0 & - \\
\hline Viburnum opulus & 1 & 20 & - \\
\hline \multicolumn{4}{|l|}{ Herbaceous plants } \\
\hline Fragaria $\times$ ananassa & 2 & 1.5 & - \\
\hline$F$. vesca & 1 & 239 & - \\
\hline Tussilago farfara (30) & 1 & 9 & ++ \\
\hline Urtica dioica & 1 & 0 & +++ \\
\hline
\end{tabular}

The sample size was 100 leaves (if not, the number of leaves is indicated in brackets). ${ }^{\text {b }}-$, no eriophyids found;,$+<5 ;++, 6-10 ;+++,>10$ eriophyids/leaf. ${ }^{\mathrm{c}} \mathrm{M}$, samples from Mustila arboretum. 


\section{TABLE 2}

Occurrence $^{\mathrm{a}}$ of phytoseiid species on apple trees and the surrounding vegetation

\begin{tabular}{lll}
\hline $\begin{array}{l}\text { Phytoseiid } \\
\text { species }\end{array}$ & Apple trees & Found also on: \\
\cline { 2 - 3 } & $\begin{array}{l}\text { Sprayed } \\
(\mathrm{n}=29)\end{array}$ & $\begin{array}{l}\text { Unsprayed } \\
(\mathrm{n}=19)\end{array}$ \\
\hline
\end{tabular}

Phytoseius macropilis (Banks)

$\begin{array}{cl}4.2 & 46.1 \\ 17.2 \% & 78.9 \%\end{array}$

Euseius finlandicus (Oudemans)

$8.0 \quad 73.2$

$41.4 \% \quad 73.7 \%$

Amblyseius reductus Wainstein
$\begin{array}{ll}1.0 & 2.3\end{array}$
$3.4 \% \quad 5.3 \%$
A. macrophylla, F. vesca, T. farfara,
U. glabra

A. hippocastani, C. avellana,

F. grandifolia, Fragaria $\times$ ananassa,

$P$. avium, $P$. padus, $R$. fruticosus,

R. rubrum, $S$. caprea, $S$. aucuparia,

$S$. thuringiana, T. americana, U. glabra,

V. opulus

A. platanoides, A. hippocastani, A. incana,

A. spicata, A. macrophylla, B. lutea, C. alba,

$C$. avellana, $C$. coccinea, $F$. grandifolia,

$F$. vesca, F. excelsior, J. ailanthifolia,

$J$. cinerea, J. mandshurica, $P$. avium,

P. padus, $P$. rhoifolia, $P$. communis, $R$. nigrum,

$R$. rubrum, R. uva-crispa, R. fruticosus,

$R$. odoratus, Salix sp., $S$. caprea,

S. thuringiana, T. americana, T. cordata,

Tilia $\times$ euchlora, U. glabra, V. opulus

Amblyseius canadensis Chant \& Hansell
$0 \quad 45.8$
C. coccinea, $P$. padus

$0 \% \quad 26.3 \%$

Seiulus aceri (Collyer)

$\begin{array}{lll}0 & 0 & \text { A. platanoides }\end{array}$

$0 \% \quad 0 \%$

Paraseiulus talbii (Athias-Henriot)

$0 \quad 1.0$

$0 \% \quad 5.3 \%$

Paraseiulus soleiger (Ribaga)

$6.2 \quad 15.6$

$20.7 \% \quad 52.6 \%$

Paraseiulus triporus (Chant \& Shaul)

$\begin{array}{lc}2.0 & 2.4 \\ 3.4 \% & 36.8 \%\end{array}$

$\begin{array}{cl}\text { Anthoseius bakeri (Garman) } & \\ 0 & 0 \\ 0 \% & 0 \%\end{array}$

Fragaria $\times$ ananassa, J. ailanthifolia

B. lutea, C. avellana, C. coccinea,

F. grandifolia, F. excelsior, J. cinerea,

$J$. mandshurica, $P$. rhoifolia, $S$. thuringiaca,

T. cordata, Tilia $\times$ euchlora, U. glabra

A. platanoides, A. hippocastani, C. avellana,

F. vesca, $P$. avium, P. padus, $P$. rhoifolia,

R. rubrum, $R$. uva-crispa, S. aucuparia,

$R$. odoratus, $U$. glabra

R. rubrum 


\begin{tabular}{|c|c|c|c|}
\hline \multirow{2}{*}{$\begin{array}{l}\text { Phytoseiid } \\
\text { species }\end{array}$} & \multicolumn{2}{|c|}{ Apple trees } & \multirow[t]{2}{*}{ Found also on: } \\
\hline & $\begin{array}{l}\text { Sprayed } \\
(\mathrm{n}=29)\end{array}$ & $\begin{array}{l}\text { Unsprayed } \\
(\mathrm{n}=19)\end{array}$ & \\
\hline \multicolumn{4}{|c|}{ Anthoseius rhenanus (Oudemans) } \\
\hline & 2.0 & 5.8 & A. glutinosa, C. coccinea, J. ailanthifolia, \\
\hline & $3.4 \%$ & $26.3 \%$ & P. avium, $R$. nigrum, $R$. idaeus, $S$. aucuparia \\
\hline \multicolumn{4}{|c|}{ Anthoseius gilvus (Wainstein) } \\
\hline & 0 & 1.0 & n.a. \\
\hline & $0 \%$ & $5.3 \%$ & \\
\hline \multicolumn{4}{|c|}{ Typhlodromus richteri Karg } \\
\hline & 0 & 1.5 & A. platanoides, $S$. aucuparia \\
\hline & $0 \%$ & $10.5 \%$ & \\
\hline
\end{tabular}

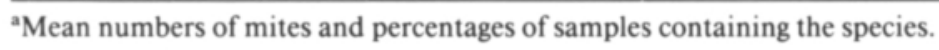

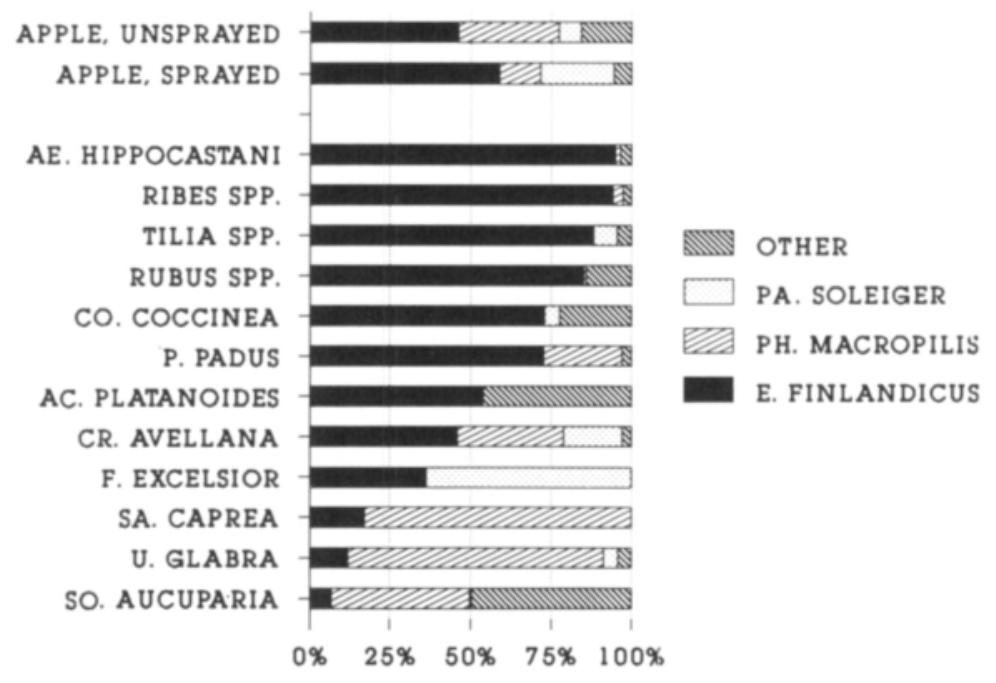

Fig. 1. The composition of phytoseiid species on unsprayed and sprayed apple trees compared with twelve deciduous trees and bushes. Sampling in August-September 1989.

were Phytoseius macropilis (Banks), Euseius finlandicus (Oudemans), Paraseiulus soleiger (Ribaga), Paraseiulus triporus (Chant \& Shaul), Amblyseius canadensis Chant \& Hansell and Anthoseius rhenanus (Oudemans); E. finlandicus, Ph. macropilis, $\mathrm{A}$. canadensis and $\mathrm{Pa}$. soleiger occurred in the highest densities. Other species occurred in only a few samples and in very low densities. 
TABLE 3

Sprayings performed in 1989, and mean numbers of phytoseiids in sprayed apple orchards

\begin{tabular}{|c|c|c|c|c|}
\hline \multirow[t]{2}{*}{ Location } & \multicolumn{3}{|c|}{ Pesticides and number of applications } & \multirow{2}{*}{$\begin{array}{l}\text { Phytoseiids/ } \\
\text { sample }\end{array}$} \\
\hline & Fungicide ${ }^{a}$ & Acaricide $^{\mathrm{b}}$ & Insecticide $^{c}$ & \\
\hline Pohja & dith:8 & flub: 1 & dime: 1 & 22.7 \\
\hline Virkkala & bite: 5 & chin: 1 & azin:1 & 12.0 \\
\hline Pälkäne & dith:3 & chin:1 & - & 9.5 \\
\hline Paimio & dith:5 & chin:2, fens:1 & dime: 1 & 2.5 \\
\hline Geta & bite: 6 & chin: 1 , chlo: 1 & azin:2 & 2.0 \\
\hline Bromarv & $\begin{array}{l}\text { bite: } 1 \text {, dich:1 } \\
\text { dith: } 9\end{array}$ & chin: 1 , tolu: 2 & - & 1.0 \\
\hline Pohja & bite:3, dith:5 & chin: 1 & azin:3 & 1.0 \\
\hline Lohjansaari & dith:5, trif: 4 & chin: 1 & oxyd:1 & 1.0 \\
\hline Virkkala & $\begin{array}{l}\text { bite: } 1 \text {, dith:1 } \\
\text { trif:2 }\end{array}$ & - & azin: 1 , oxyd: 2 & 0.5 \\
\hline Geta & $\begin{array}{l}\text { bite: } 2 \text {, dich: } 2 \text {, } \\
\text { dith: } 2 \text {, trif: } 1\end{array}$ & - & $\begin{array}{l}\text { azin: } 2 \text {, dime: } 2 \text {, } \\
\text { oxyd: } 1\end{array}$ & 0 \\
\hline Geta & $\begin{array}{l}\text { bite:3, copp: } 1 \text {, } \\
\text { dich:3, dith:2 }\end{array}$ & chin:1 & azin: 1 , dime: 2 & 0 \\
\hline Godby & $\begin{array}{l}\text { bite: } 1 \text {, dich:1 } \\
\text { dith:6 }\end{array}$ & - & azin:1, oxyd:1 & 0 \\
\hline Godby & dith:6 & chin:2 & azin: 1 , oxyd:3 & 0 \\
\hline Lohjansaari & dith:6, trif:2 & chin:1 & oxyd:1 & 0 \\
\hline Lohjansaari & bite: 3 , dith: 4 & dico: 1 & oxyd:1 & 0 \\
\hline Piikkiö & bite: 6 & chin: 1 & oxyd:1 & 0 \\
\hline
\end{tabular}

aFungicides: bitertanol; copperoxychlorid; dichlofluanid; dithianon; triforine.

'AAaricides: chinomethionate; chlorbenzilate; dicofol; fenson; flubenzimine; toluene.

'Insecticides: azinphosmethyl; dimethoate; oxydemetonmethyl.

The material collected for the 1985 survey was rechecked, and one correction was made to the list of phytoseiids on the apple tree: Amblyseius cucumeris (Oudemans) should be $A$. reductus Wainstein (Kropczynska and Tuovinen, 1988). Furthermore, one specimen of Paraseiulus triporus, earlier identified erroneously as $\mathrm{Pa}$. soleiger, was identified from the same material (T. Edland, personal communication, 1988).

Paraseiulus talbii (Athios-Henriot) was found as a new species on the apple tree in Finland, and Seiulus aceri (Collyer) was recorded for the first time on the maple (Acer platanoides). The phytoseiid species found on apple trees now include Phytoseius macropilis, Euseius finlandicus, Amblyseius reductus, A. canadensis, Paraseiulus talbii, Pa. soleiger, Pa. triporus, Anthoseius bakeri (Garman), An. rhenanus, An. gilvus (Wainstein) and Typhlodromus richteri Karg.

Euseius finlandicus occurred on $85 \%$ of the plant species containing phytoseiids (on 33 of 46 plants). The other species with a wide host-plant selection were $P$. macropilis (on 14 plants), $P a$. soleiger (on 12 plants) and $P a$. 
triporus (on 12 plants; Table 2). These four species accounted for $94.7 \%$ of all individuals $(n=2219)$ in unsprayed apple leaf samples; the same species, especially E. finlandicus and $\mathrm{Ph}$. macropilis, were also dominant on many common or otherwise interesting plants near orchards (Fig. 1).

The presence of eriophyid mites in leaf samples does not seem to affect the density of phytoseiids (Table 1). On the dwarf birch (Betula nana) and the nettle (Urtica dioica), eriophyid populations existed, but not a single phytoseiid mite was found. The nettles were growing near the sprayed apple trees, and had obviously been sprayed with the same chemicals. Eriophyids were rather common on Alnus spp., but only a few phytoseiids were found on these trees.

Six phytoseiid species were found in low densities on sprayed apple trees (Table 2). Euseius finlandicus, Pa. soleiger and Ph. macropilis were the most common species in these orchards, where several fungicidal and a few insecticidal and acaricidal sprayings had been performed (Table 3). Phytoseiids were almost entirely absent from orchards where oxydemetonmethyl had been used. In two of the orchards, no insecticidal sprayings had been made in 1989, but in the previous year, dimethoate (Pälkäne) and oxydemetonmethyl plus dimethoate (Bromarv) had been used (Table 3 ). In the orchards where about 10-20 phytoseiid mites/sample were found, the trees had been sprayed with bitertanol or dithianon for scab control, with acaricides once and with azinphosmethyl or dimethoate no more than once.

\section{DISCUSSION}

Although the role of phytoseiid mites as important predators of $P$. ulmi on apple trees had already been observed in the 1930s in Finland (Listo et al., 1939 ), the first survey to search for and identify phytoseiids was not conducted until 1985 (Kropczynska and Tuovinen, 1987, 1988). The observations made for the present study and that performed four years earlier showed that the main species compositions and the densities of phytoseiid mites are stable in a particular orchard as long as the trees have not been sprayed. Likewise, in Canada, Amano and Chant (1990) noted that populations of E. finlandicus and Ph. macropilis, the two dominant phytoseiid species in an abandoned orchard, were stable in two consecutive years.

The most common phytoseiid mite species on apple trees in Finland, $E$. finlandicus and Ph. macropilis, are known as predators of spider mites and eriophyid mites (Chant, 1959; Böhm, 1960; Karg, 1972). Both species also reproduce when fed only on pollen, and E. finlandicus reproduces also if fed only on spores and hyphae of the apple mildew Podosphaera leucotricha (Ell. \& Ev.) (Kropczynska-Linkiewicz, 1973). These two species of phytoseiids are clearly the best adapted to the Finnish climate and to diverse habitats and food resources. 
As Finnish apple orchards are small, with homogeneous blocks typically under 2 ha and very seldom over 10 ha, the significance of the surrounding vegetation as a reservoir and source of phytoseiid mites is more important than in larger uniform apple cultivations. If the harmful agents in chemical pest control are replaced with more benign pesticides, predators and parasitoids will migrate from surrounding vegetation and colonization may succeed. As phytoseiids do not walk long distances (van de Vrie, 1985), the main means of long-range dispersal is the wind. Hoy (1982) reported that the phytoseiid mite Metaseiulus occidentalis (Nesbitt) dispersed from one spot throughout a 32-ha almond orchard in one year. Phytoseiids can disperse via air turbulence for at least $200 \mathrm{~m}$, and probably much more than that (Hoy et al., 1985). The capacity of phytoseiids for long-distance airborne dispersal seems to be so high that they might colonize small orchards within a short period.

The speed of phytoseiid migration from outside trees or bushes into an orchard depends on many factors, such as distance, prevailing wind direction, frequency of high winds, air temperature and relative humidity (Johnson and Croft, 1979; Hoy et al., 1985). The above-mentioned studies support the idea that phytoseiids may colonize small apple orchards in a few months once harmful sprayings have been stopped.

In Switzerland, a method for transferring phytoseiids from one vineyard to another has recently been introduced and implemented on a larger scale (Boller and Remund, 1986). It would also be useful to study whether artificial transfer from wild host plants would significantly accelerate the migration of phytoseiids into apple orchards.

Other generally occurring good host plants for phytoseiids besides the apple tree are blackcurrant, mountain ash, hazel, purple raspberry, bird cherry, lime (Tilia cordata) and elm (Ulmus glabra). These trees and bushes are hosts for many eriophyid mite species (Liro and Roivainen, 1951), although in this study eriophyid mites were rather scarce. Other mite groups were not considered, but with the exception of the European red spider mite on sprayed apple trees, their densities were much lower (cf. Kropczynska and Tuovinen, 1988).

Many studies report high densities of phytoseiid mites on hazel (Hansen and Johnsen, 1986; Edland, 1987; Boller et al., 1988). Although not very common in Finland, this bush can be found near many apple orchards. Another very good host plant for phytoseiids is blackberry (Boller et al., 1988), but in the present study only a few mites were found on it. Rubus odoratus, in contrast, was abundantly inhabited by $E$. finlandicus. Only a few phytoseiids were found on common raspberry ( $R$. idaeus), but the wild raspberries should be studied more thoroughly because they are very common in forest margins.

Although samples of some plant species were taken in only a single or a few locations, the results show which plant species can support high numbers of 
phytoseiids. The presence of hairs on a leaf surface seems to be an important prerequisite for high phytoseiid density (cf. Overmeer and van Zon, 1984).

Prey density does not seem to have any significant effect on the presence and density of $E$. finlandicus and Ph. macropilis. Although only the density of eriophyid mites was estimated, the general trend was for phytoseiids also to be found on plants where only very few or no prey mites were present, at least on leaves. Obviously, these species have alternative food sources: pollen, spores and plant fluids, and possibly also the mites inhabiting branches.

Prunus padus, Sorbus aucuparia and Salix caprea are all common trees in forest margins and around orchards. Euseius finlandicus and $\mathrm{Ph}$. macropilis were dominant on $\mathrm{Pr}$. padus, where their densities were almost the same as on unsprayed apple trees. Salix caprea is an interesting tree, because it provides nourishment for honey bees in early spring, before apple blooming time. It should therefore be conserved and even used in windbreak hedges. As So. aucuparia is the main host of the most important apple pest in Finland, the apple fruit moth (Argyresthia conjugella (Zell.)), this tree should not be grown near apple orchards. Phytoseius macropilis was the dominant species on both Sa. caprea and So. aucuparia.

The prospects of finding strains resistant to OPs in any phytoseiid species do not look promising in the light of the present study, although 10-30 specimens of $\mathrm{E}$. finlandicus and $\mathrm{Pa}$. soleiger were found in some sprayed samples. However, the findings suggest that these populations may possess at least a low level of resistance to dimethoate and azinphosmethyl, and clearly show the destructive effect of pesticide spraying on predatory mites. Use of oxydemetonmethyl, one of the common insecticides, should be restricted if naturally occurring phytoseiids are to be conserved. Because the species most widely known to have developed resistance to OPs, $T$. pyri, has not been found in Finland so far, the introduction and release of this species into Finnish orchards should be studied, as should the reasons why this species does not occur in Finland.

\section{ACKNOWLEDGEMENTS}

The authors thank Dr. Eiko Shaul for the identification of Amblyseius reductus and Paraseiulus talbii.

\section{REFERENCES}

Amano, H. and Chant, D.A., 1990. Species diversity and seasonal dynamics of Acari on abandoned apple trees in southern Ontario, Canada. Exp. Appl. Acarol., 8: 71-96.

Boller, E.F. and Remund, U., 1986. Methoden der Raubmilben-Ansiedlung in Rebbergen der Ostschweiz. Schweiz. Z. Obst-Weinbau, 122: 287-291.

Boller, E.F., Remund, U. and Candolfi, M.P., 1988. Hedges as potential sources of Typhlodro- 
mus pyri, the most important predatory mite in vineyards of northern Switzerland. Entomophaga, 33: 249-255.

Böhm, H., 1960. Untersuchungen uber Spinnmilbenfeinde in Österreich. Pflanzenschutzberichte, 25: 23-46.

Chant, D.A., 1959. Phytoseiid Mites (Acarina: Phytoseiidae). Part I: Bionomics of seven species in Southeastern England. Part II: A taxonomic review of the family Phytoseiidae, with descriptions of 38 new species. Can. Entomol., 41, Suppl. 12., 164 pp.

Collyer, E., 1964. A summary of experiments to demonstrate the role of Typhlodromus pyri Scheut. in the control of Panonychus ulmi (Koch) in England. In: Proc. First Int. Congr. Acarology, Fort Collins, CO, 2-7 September 1963. Acarologia 6, Facs. Hors Série, pp. 363371.

Croft, B.A. and Barnes, M.M., 1971. Comparative studies on four strains of Typhlodromus occidentalis. III. Evaluations of releases of insecticide resistant strains into an apple orchard ecosystem. J. Econ. Entomol., 64: 845-850.

Dosse, G., 1960. Uber der Einfluss der Raubmilbe Typhlodromus tiliae Oud. auf die Obstbaumspinnmilbe Metatetranychus ulmi Koch (Acari). Pflanzenschutzberichte, 24: 113-137.

Edland, T., 1987. Rovmiddar (Phytoseiidae) på frilandsvekstar i Norge. [Predacious mites (Phytoseiidae) on field-grown plants in Norway.] Entomol. Tidskr., 108: 21-22.

Hansen, E.W. and Johnsen, S., 1986. Rovmider av familien Phytoseiidae i Danmark (Acarina, Gamasina). [Predacious mites in the family Phytoseiidae in Denmark (Acarina, Gamasina ).] Entomol. iMedd., 53: 137-142.

Hoy, M., 1982. Aerial dispersion and field efficacy of a genetically improved strain of the spider-mite predator Metaseiulus occidentalis. Entomol. Exp. Appl., 32: 205-212.

Hoy, M., Groot, R. and van de Baan, H.E., 1985. Influence of aerial dispersal on persistence and spread of pesticide-resistant Metaseiulus occidentalis in California almond orchards. Entomol. Exp. Appl., 37: 17-31.

Hoyt, S.C., 1972. Resistance to azinphosmethyl of Typhlodromus pyri (Acarina: Phytoseiidae) from New Zealand. N.Z. J. Sci., 15: 16-21.

Johnson, D.T. and Croft, B.A., 1979. Factors affecting the dispersal of Amblyseius fallacis in an apple tree ecosystem. In: J. Rodriguez (Editor), Recent Advances in Acarology, Vol. I. Academic Press, New York, NY, pp. 477-483.

Karg, W., 1971. Die freilebenden Gamasina (Gamasides), Raubmilben. Die Tierwelt Deutschlands und der angrenzenden Meeresteile, Teil 59. Gustav Fischer, Jena, 475 pp.

Karg, W., 1972. Untersuchungen uber die Korrelation zwischen dominierenden Raubmilbenarten und ihrer möglichen Beute in Apfelanlagen. Arch. Pflanzenschutz., 8: 29-52.

Karg, W., 1982. Diagnostik und Systematik der Raubmilben aus der Familie Phytoseiidae Berlese 1916 in Obstanlagen. Zool. Jahrb. Syst., 109: 188-210.

Karg, W., 1983. Systematische Untersuchung der Gattungen der Raubmilbenfamilie Phytoseiidae Berlese 1916 mit der Beschreibung von 8 neuen Arten. Mitt. Zool. Mus. Berlin, 59: 293328.

Kropczynska-Linkiewicz, D., 1973. Studies on feeding of four species of phytoseiid mites (Acarina: Phytoseiidae). In: M. Daniel and B. Rosický (Editors), Proc. 3rd Int. Congr. Acarology, Prague, 31 August-6 September 1971. Czechoslovak Academy of Sciences, Prague, pp. 225-227.

Kropczynska, D. and Tuovinen, T., 1987. Predatory mites (Acari: Phytoseiidae) occurring on apple-trees in Finland. Entomol. Tidskr., 108: 31-32.

Kropczynska, D. and Tuovinen, T., 1988. Occurrence of phytoseiid mites (Acari: Phytoseiidae) on apple trees in Finland. Ann. Agric. Fenn., 27: 305-314.

Liro, I.J. and Roivainen, H., 1951. Suomen eläimet (Animalia Fennica) 6. Äkämäpunkit (Eriophyidae ). [Fauna of Finland (Animalia Fennica) 6. Gall mites (Eriophyidae).] Vanamo, Turku, Finland, 281 pp. 
Listo, J., Listo, E.-M. and Kanervo, V., 1939. Studies of the fruit tree red mite (Paratetranychus pilosus C. \& F. ). (Summary). Valt. Maatalouskoetoiminnan Julk., 99: 1-143.

McMurtry, J.A. and van de Vrie, M., 1973. Predation by Amblyseius potentillae (Garman) on Panonychus ulmi (Koch) in simple ecosystems (Acarina: Phytoseiidae, Tetranychidae). Hilgardia, 42: 17-34.

Miedema, E., 1987. Survey of phytoseiid mites (Acari: Phytoseiidae) in orchards and surrounding vegetation of northwestern Europe, especially the Netherlands. Keys, descriptions and figures. Neth. J. Plant Pathol., 93, Suppl. 2: 1-64.

Overmeer, W.P.J. and van Zon, A.Q., 1983. Resistance to parathion in the predacious mite Typhlodromus pyri Scheuten (Acarina: Phytoseiidae). Meded. Fac. Landbouwwet. Rijksuniv. Gent, 43: 247-251.

Overmeer, W.P.J. and van Zon, A.Q., 1984. The preference of Amblyseius potentillae (Garman) (Acarina: Phytoseiidae) for certain plant substrates. In: D. Griffiths and C. Bowman (Editors), Proc. 6th Int. Congr. Acarology, Edinburgh, September 1982, Vol. 1. Ellis Horwood, Chichester, pp. 591-596.

Van de Vrie, M., 1985. Control of Tetranychidae in crops. Greenhouse ornamentals. In: W. Helle and M.W. Sabelis (Editors), Their Biology, Natural Enemies, and Control Spider Mites. Vol. B. Elsevier, Amsterdam, pp. 273-283.

Wildbolz, T., 1986. Raubmilben als Spinnmilbenfeinde im Obstbau. Schweiz. Z. Obst-Weinbau, 120: 433-435. 


\section{Influence of Surrounding Trees and Bushes on the Phytoseiid Mite Fauna on Apple Orchard Trees in Finland}

T. TUOVINEN

Institute of Plant Protection, Agricultural Research Centre of Finland, FIN-31600 Jokioinen (Finland)

\section{ABSTRACT}

Tuovinen, T. Influence of surrounding trees and bushes on the phytoseiid mite fauna on apple orchard trees in Finland. Agric. Ecosystems Environ.

Predacious phytoseiid mites were collected from apple orchard trees and from nearby deciduous trees and bushes in order to compare the species composition and densities on apple as well as around orchards in Southern Finland. The majority of the specimens belonged to Euseius finlandicus and Phytoseius macropilis, which are considered to be the most relevant for natural control of the European red spider mite, Panonychus ulmi, in Finland.

Phytoseiids occurred only occasionally in insecticide-treated orchards bordered by just a few suitable host plants, whereas they were more abundant in other sprayed orchards that were surrounded by many suitable host plants. $P$. macropilis was the dominant phytoseiid species on unsprayed apple trees, but $E$. finlandicus was more common in sprayed orchards. Both species were common also on host plants where spider mites were scarce.

In a 2-ha orchard that was surrounded by deciduous trees and bushes, the mean phytoseiid mite density was 0.3 3.1/leaf 15 days after a dimethoate treatment. Phytoseiid mites were encountered in the vicinity on the following trees: bird cherry, Prunus padus (0.3 mites/leaf); hazel, Corylus avellana (9.8/leaf); honeysuckle, Lonicera xylosteum (2.7/leaf); lime, Tilia spp. (2.4/leaf); oak, Quercus robur (1.2/leaf) and great sallow, Salix caprea (0.8/leaf). E. finlandicus was the dominant species, both on apple trees and on other host plants, with the exception of great sallow trees. Phytoseiid densities on adjacent vegetation had a noticeable effect on phytoseiid densities and species composition on apple orchard trees. Tall trees, such as oak and lime, are probably more important than low bushes as natural sources of phytoseiids for aerial dispersal into orchards. The migration of $E$. finlandicus into orchards from surrounding vegetation is concluded to be faster than that of $P$. macropilis. 


\section{INTRODUCTION}

In integrated pest management on apple trees, predacious phytoseiid mites (Acari: Phytoseiidae) have a prominent role as natural enemies of the European red spider mite Panonychus ulmi (Koch) (Acari: Tetranychidae) and other phytophagous mites (Collyer, 1964; Wildbolz and Staub, 1986; Trapman, 1989). Phytoseiid strains resistant to organophosphorus insecticides have been utilized in many countries (Hoyt, 1972; Overmeer and van Zon, 1983; Genini and Baillod, 1987). Resistant strains of phytoseiid mites have not been reported in Finland. The most important species in Europe, Typhlodromus pyri Scheuten, in which resistant strains have been detected, is very rare in Finland. It has been recorded only in the southwestern Åland islands (Tuovinen, unpublished). The importation and release of resistant strains of $T$. pyri into Finnish orchards may not offer a long-term solution to the spider mite problem because $T$. pyri may not tolerate the low temperatures typical of the Finnish winter (c.f. MacPhee, 1963).

Phytoseiid mites are common on unsprayed apple trees in Finland, and spider mites are rare or entirely absent from such trees (Kropczynska and Tuovinen, 1988). Many other deciduous trees and bushes maintain high phytoseiid populations, including the same species which dominate on apple trees (Tuovinen and Rokx, 1991). The surrounding vegetation is therefore assumed to be a reservoir for phytoseiid mites from which they migrate onto apple trees and thus regulate the density of phytophagous mites. This assumption was evaluated in commercial, insecticide-treated orchards during 1989 and 1991 . The objective was to clarify the possible effects of adjacent plants on the occurrence of phytoseiid mites on apple trees, as well as to outline some of the conditions that would facilitate natural control of the European red spider mite.

\section{MATERIALS AND METHODS}

In 1989, 14 insecticide-treated apple orchards in Southern Finland and on the Åland islands were studied (Table 1). At the end of the season (August-September), samples of 100 leaves were collected from 10-20 apple trees in the 14 sprayed orchards, from single or a few unsprayed apple trees, if available nearby, and from 5-10 specimens of the main species of deciduous trees and bushes in the vicinity. In 1989, phytoseiid mites, and in 1991 also spider mites and tydeid mites (Acari: Tydeidae) were collected and counted.

The leaf samples were soaked in warm soap water to remove and kill the mites on the leaves. After 24 hours, the soapy water with leaves was passed through $1 \mathrm{~mm}$ and $0.1 \mathrm{~mm}$ mesh sieves. 
The phytoseiid mites were counted, placed in small tubes, and stored in $70 \%$ alcohol until mounting in Hoyer solution. The phytoseiid mites were identified using the keys of Karg (1991) and Miedema (1987), and the reference collections of T. Edland (personal communication, 1988) and Kropczynska and Tuovinen (1988).

The number of phytoseiids/sample was subjected to regression analysis to test the effect of time elapsed from the last harmful spray (Table 1). Harmful insecticides included azinphosmethyl, dimethoate and oxydemetonmethyl, and less harmful acaricides and fungicides (chinomethionate, chlorbenzilate, dichlofluanid, dicofol, flubenzimine and triforine) (Karg et al., 1987, Boller et al., 1989, Hassan et al., 1991). The relationship of phytoseiid density in surrounding vegetation to the density on sprayed apple trees was assessed using Spearman's correlation. The phytoseiid density in surrounding vegetation was calculated as the sum of phytoseiid mites found on non-orchard plants using a coefficient varying from 0.2 to 20 according to the estimated size of the bushes or trees compared to apple trees (Table 1). The unsprayed apple trees were not included in the calculation, because they were few in number and were situated near dwellings. The mean densities of phytoseiid mites on different plants were calculated, including some additional samples taken from similar environments in 1990-1991.

In 1991, apple leaf samples were collected from northern, western and eastern parts of a 2-ha orchard, and from the main surrounding trees and bushes, respectively. The main surrounding trees and bushes nearby (10-20 m away) were: on the western side willow (Salix spp.) and a few bird cherry trees (Prumus padus L.); on the northern side tall oaks (Quercus robur L.), hazels (Corylus avellana L.) and honeysuckles (Lonicera xylosteum L.); and on the western side tall limes (Tilia cordata Mill.) and hazels. On the southern side of the orchard, about $30 \mathrm{~m}$ away, there were newly planted young nursery trees and no big trees. The orchard had been sprayed with dimethoate (120 $\mathrm{g}$ a.i./100 l, $500 \mathrm{~g}$ a.i./ha) 15 days prior to sampling. From tall oak and lime trees, lower $(<2 \mathrm{~m})$ and higher leaves (10-12 m) were sampled again in July 1992 to check the vertical distribution of phytoseiid mites. The leaf samples were weighed. The number of mites/tree was calculated by estimating the weight of fresh leaves of whole trees according to the size of the trees.

\section{RESULTS}

Nine phytoseiid species in seven genera were identified in this study. Seven of the species occurred on apple trees (Table 2). On adjacent plants, the mean densities of phytoseiids varied between 0-1063 mites/100 leaves (Table 3). The 14 orchards studied in 1989 included orchards with 
adjacent vegetation inhabited by high densities of phytoseiid mites and orchards with sparse phytoseiid communities on adjacent plants (Table 4). Phytoseiid mites were encountered in all unsprayed apple leaf samples. The orchards studied were divided into three groups: in Group 1 the adjacent vegetation was characterized by high phytoseiid numbers, with moderate to high phytoseiid numbers on sprayed apple trees; in Group 2 the adjacent vegetation was characterized by high phytoseiid numbers, but low phytoseiid numbers on sprayed apple trees; in Group 3 both the adjacent vegetation and sprayed apple trees contained low phytoseiid numbers (Table 4). There was no significant correlation between numbers of phytoseiids on sprayed apple trees and on adjacent vegetation (Spearman $\mathrm{r}=0.348, \mathrm{~N}=14, \mathrm{P}=0.12$ ). When one orchard (no. 10), with a high density of phytoseiids on a horse chestnut tree (Aesculus hippocastanum L.) in the vicinity and no phytoseiids on sprayed apple trees, was excluded from the analysis, the correlation was significant $(r=0.585$, $\mathrm{N}=13, \mathrm{P}=0.02$ ).

The interval between sampling date and the last insecticide spray rated as harmful to phytoseiids varied between 28 and 123 days (Table 1). The regression relationship between days elapsed from last insecticide treatment and density of phytoseiids on sprayed apple trees was not significant $(r=0.437, \mathrm{P}=0.12)$; neither was that of acaricide/fungicide treatment $(\mathrm{r}=0.130, \mathrm{P}=0.66)$. In orchard no. 11, harmful oxydemetonmethyl and moderately harmful chinomethionate were sprayed 87 and 36 days before sampling, respectively; 93 phytoseiids/100 leaves were detected on sprayed apple trees (Table 4). In orchards no. 3, 4, and 13, phytoseiid mites were extremely scarce on sprayed apple trees, although the intervals between last sprays and sampling dates were considerably long. Only low numbers of phytoseiid mites were encountered on adjacent non-orchard plants around these orchards, in contrast to orchard no. 11. In orchards no. 2, 7, 9, and 10, sprays were applied 27-31 days before sampling; only a few phytoseiids were detected in orchard trees, although some of the adjacent plants exhibited high phytoseiid densities (Table 4). On the adjacent vegetation in orchards no. 2 and 10, the dominant phytoseiid was Euseius finlandicus (Oudemans) which was found on individual horse chestnut trees. In orchards no. 7 and 9, the dominant species in surrounding plants was Phytoseius macropilis (Banks). In orchard no. 12, Anthoseius rhenanus (Oudemans) dominated on adjacent plants, but on unsprayed apple, P. macropilis and E. finlandicus were dominant.

P. macropilis was the dominant phytoseiid species on unsprayed apple trees and E. finlandicus on sprayed apple trees (Table 2). These two species also dominated on most of the non-orchard trees and bushes. A. rhenanus was more numerous on surrounding vegetation than on apple trees. 
Seiulus aceri (Collyer) was the only specific species detected and was found only on maple (Acer platanoides L.) (Table 4).

The numbers of phytoseiids on apple trees in a 2-ha orchard varied in August 1991, depending on the location of sample collection (Table 5). In the northern and eastern sectors of the orchard, where the phytoseiid numbers were highest, the adjacent plants comprised hazel (N, E), tall limes (E) and oaks $(\mathrm{N})$, whereas the western sector consisted of bird cherry and great sallow (Salix caprea L.) were present. E. finlandicus occurred in greater numbers than any other phytoseiid on all plants; only ca. $5 \%$ of the specimens belonged to $P$. macropilis on sprayed apple trees. The main surrounding vegetation included six tree or bush species on which the phytoseiid density varied between $0.77-21.35$ per gram of leaves. The predator-prey ratio at sampling, when counting only mobile spider mites and tydeid mites as prey, ranged between 1:0.52 - 1:2.78 on apple trees (primarily spider mites), and between 1:0.01 - 1:0.36 on other plants (primarily tydeid mites). The only exception was bird cherry trees, where the ratio was 1:5. Eriophyid mites (Acari: Eriophyidae) occurred commonly on apple trees and on most of the surrounding trees.

When total phytoseiid numbers per plant specimen in the area were estimated, oak and lime appeared to be superior because of their large size, although the phytoseiid density per leaf or per gram of leaves was much higher on hazel bushes (Table 5). In samples taken in July 1992, phytoseiid densities on the lower and higher leaves of trees did not differ much: on lime $0.8 /$ leaf in lower parts of the tree vs. 1.2/leaf on higher parts of the tree; on oak, 1.3/leaf vs. 1.1/leaf, respectively.

\section{DISCUSSION}

The data presented on species composition and densities of phytoseiids does not reveal any apparent highly consistent trend in terms of direct influence of adjacent vegetation on phytoseiid communities on sprayed apple trees. However, the results do allow some preliminary conclusions.

P. macropilis was the predominant species on all unsprayed apple leaf samples. E. finlandicus was subdominant. In Canada, E. finlandicus and P. macropilis are also common on abandoned apple trees (Amano and Chant, 1990). Unsprayed apple trees provide very good habitats for many phytoseiid mites. In the present study, they were generally inhabited by several species. In practical cultivation, a small separated area of unsprayed densely planted apple trees could be used as a phytoseiid reservoir from which shoots with high numbers of phytoseiid mites could be distributed 
into the orchard by hand. This type of distribution has been practiced in Switzerland (Wildbolz and Staub, 1986).

The value of these two dominant phytoseiid species as natural enemies of the European red spider mite differs with species. According to Dicke et al. $(1988,1990)$, E. finlandicus prefers the apple rust mite Aculus sclechtendali (Nalepa); its larval stage even suffered severe mortality when fed exclusively European red spider mites. P. macropilis preys readily on spider mites as well. Both phytoseiid species have wide ranges of food, including different phytophagous mites, pollen, fungi and plant fluids (Kropczynska-Linkiewicz, 1973). Because both species prey at least to some extent on spider mites, they are considered useful as natural control agents of the European red spider mite.

The two dominant phytoseiid species on apple trees have distinctly different locomotor habits as observed in the laboratory. E. finlandicus moves quickly and is very active, whereas $P$. macropilis moves slowly and tends to spend longer periods crouching near veins and beneath hairs. As active movement of phytoseiids is limited, locomotor migration from surrounding plants to apple trees is unlikely to explain the presence of phytoseiids on apple trees in substantial numbers a few weeks after a harmful dimethoate spray (cf. Sabelis and Dicke, 1985). Therefore long-range passive aerial dispersal is considered to be a much more important means of entry into the orchards studied. Dispersal from understory cover plants onto orchard trees is probably not common, because both E. finlandicus and P. macropilis overwinter on trees in Finland, and have not been found in numbers on grasses (Tuovinen, unpublished).

Hoy et al. (1985) documented aerial dispersal of Metaseiulus occidentalis Nesbitt at least 200 $\mathrm{m}$ in distance from source trees. Studies on $M$. occidentalis have revealed special behaviors that facilitate aerial dispersal by wind (Johnson and Croft, 1976, Hoy et al., 1984). Dunley and Croft (1990) studied the migration of M. occidentalis and T. pyri from source trees and discovered that M. occidentalis immigrated and colonized new downwind trees faster than T. pyri. A possible reason for lower aerial dispersal of $T$. pyri is concluded to be its limited movement compared to M. occidentalis. Lack of food may also release behavior that facilitates phytoseiid dispersal (Hoy et al., 1984). There are no similar studies for E. finlandicus or P. macropilis. However, on account of the higher activity level of E. finlandicus, it may disperse rapidly from adjacent plants during windy weather. This would better explain the difference in dominant species observed on unsprayed compared with sprayed apple trees than would a possible development of resistance to pesticides in E. finlandicus. Previous observations in many Finnish orchards have shown that immediately after the spraying of harmful pesticides, either no or extremely few active phytoseiid mites can be found 
(Tuovinen, unpublished). Hence, no resistance is expected to have developed in the species which occur in Finnish orchards. Similarly, Thistlewood (1991) found E. finlandicus on untreated apple trees and in some fungicide-treated apple orchards, but $P$. macropilis only in abandoned orchards. However, possible resistance to azinphosmethyl and dimethoate in some strains of E. finlandicus is currently being studied (T. Kostiainen, Univ. of California, Berkeley, personal communication).

The presence of specific prey species is not a prerequisite for the most common phytoseiid mite species, E. finlandicus and P. macropilis (Tuovinen and Rokx, 1991). In this study, the presence of mobile spider mites and tydeid mites was taken into consideration. High numbers of phytoseiids were found even in samples with very low prey densities. The capability of many phytoseiids, e.g. E. finlandicus, to survive without any animal prey has been noted also by Dicke et al. (1990). This capability may explain the overall distribution of E. finlandicus and P. macropilis in different habitats. Birch (Betula spp.) pollen, which is good food for E. finlandicus (Schausberger, 1991), is available on leaves of many plants and may serve as food for long periods.

The phytoseiid species composition on sprayed trees appeared to correspond to that on adjacent vegetation in some but not all of the orchards studied. Differences may be attributed to the diverse types and structure of the surrounding vegetation. Future studies, in which data was gathered on the number of trees or bushes around orchards, information on mite densities and prevailing wind direction would be necessary for predictive purposes. It is, however, obvious on the basis of this study that the presence of tall trees, such as oak and lime, which E. finlandicus inhabits, offers a good opportunity for rapid phytoseiid aerial migration onto apple trees. Because phytoseiids inhabit the entire tree canopy, they may be abundant on higher leaves, where air movement is greatest. Other good host plants, such as hazel, may also be important phytoseiid sources, especially if hazel bushes are situated near apple orchard trees. Boller et al. (1988) also concluded that hazel bush hedges may serve as a reservoir of phytoseiid mites in vineyards. In practice, the presence of various deciduous trees or bushes around orchards could facilitate phytoseiid colonization of orchards after toxic insecticide or acaricide treatments, thus improving the natural control of the European red spider mite.

\section{ACKNOWLEDGEMENTS}

I am grateful to Prof. Ron Prokopy for an invitation to the symposium and help in preparing the manuscript. I thank Dr. Diane Alston, Dr. Donn Johnson and Dr. Robert L. Bugg for comments on the manuscript. 


\section{REFERENCES}

Amano, H. and Chant, D.A., 1990. Species diversity and seasonal dynamics of Acari on abandoned apple trees in southern Ontario, Canada. Exp. Appl. Acarol., 8: 71-96.

Boller, E.F., Remund, U. and Candolfi, M.P., 1988. Hedges as potential sources of Typhlodromus pyri, the most important predatory mite in vineyards of northern Switzerland. Entomophaga, 33: 249-255.

Boller, E., Bigler, F., Bieri, M., Häni, F. and Stäubli, A., 1989. Nebenwirkungen von Pestiziden auf die Nützlingsfauna wirtschaftlichen Kulturen. Shcweiz. Landw. Fo., 28: 3-40.

Collyer, E., 1964. A summary of experiments to demonstrate the role of Typhlodromus pyri Scheut. in the control of Panonychus ulmi (Koch) in England. Acarologia, Proc. First Int. Congr. Acarology, Fort Collins, Colorado, USA, 1963: 363-371.

Dicke, M., Sabelis, M.W. and de Jong, M., 1988. Analysis of prey preference in phytoseiid mites by using olfactometer, predation models and electrophoresis. Exp. Appl. Acarol., 5: 225-241.

Dicke, M., Sabelis, M.W., de Jong, M. and Alers, M.P.T., 1990. Do phytoseiid mites select the best prey species in terms of reproductive success? Exp. Appl. Acarol., 8: 161-174.

Dunley, J.E. and Croft, B.A., 1990. Dispersal between and colonization of apple by Metaseiulus occidentalis and Typhlodromus pyri (Acarina: Phytoseiidae). Exp. Appl. Acarol., 10: 137-149.

Genini, M. and Baillod, M., 1987. Introduction de souches resistantes de Typhlodromus pyri (Scheuten) et Amblyseius andersoni Chant (Acari: Phytoseiidae) en vergers de pommiers. (Summary: The introduction of resistant strains of Typhlodromus pyri (Scheuten) and Amblyseius andersoni Chant (Acari: Phytoseiidae) in apple orchards.) Rev. Suisse Viticult. d'Arboricult. d'Horticult., 19: 115-123.

Hassan, S.A., Bigler, F., Bogenschütz, H. Boller, E., Brun, J., Calis, J.N.M., Chiverton, P., Coremans-Pelseneer, J., Duso, C., Lewis, G.B., Mansour, F., Moreth, L. Oomen, P.A., Overmeer, W.P.J., Polgar, L., Rieckman, W., Samsøe-Petersen, L., Stäubli, A., Sterk, G., Tavares, K., Tuset, J.J. and Viggiani, G. 1991. Results of the fifth joint pesticide testing programme carried out by the IOBC/WPRS-working group "Pesticides and Beneficial Organisms". Entomophaga, 36: 55-67.

Hoy, M.A., van de Baan, H.E, Groot, J.J.R. and Field, R.P., 1984. Aerial movements of mites in almonds: implications for pest management. Calif. Agric., Sept. 1984: 21-23.

Hoy, M., Groot, R. and van de Baan, H.E., 1985. Influence of aerial dispersal on persistence and spread of pesticide-resistant Metaseiulus occidentalis in California almond orchards. Entomol. Exp. Appl., 37: 17-31. 
Hoyt, S.C., 1972. Resistance to azinphosmethyl of Typhlodromus pyri (Acarina: Phytoseiidae) from New Zealand. N.Z. J. Science, 15: 16-21.

Johnson, D.T. and Croft, B.A., 1976. Laboratory study of dispersal behaviour of Amblyseius fallacis (Acarina: Phytoseiidae). Ann. Entomol. Soc. Am., 69: 1019-1023.

Karg, W. Gottwald, R. and Freier, B., 1987. Die Selektivität von Pflanzenschutzmitteln und ihre Bedeutung. Nachr.-Bl. Pflanzenschutzd. DDR, 41: 218-223.

Karg, W., 1991. Die Raubmilbenarten der Phytoseiidae Berlese (Acarina) Mitteleuropas sowie angrenzender Gebiete. Zool. Jb. Syst., 118: 1-64.

Kropczynska-Linkiewicz, D., 1973. Studies on feeding of four species of phytoseiid mites (Acarina: Phytoseiidae). In: Daniel, M. and Rosicky, B. (Eds), Proc. 3rd Int. Congr. Acarology, Prague, 31 August-6 September 1971, pp. 225-227. Czechoslovak Academy of Sciences, Prague.

Kropczynska, D. and Tuovinen, T., 1988. Occurrence of predatory mites (Acari: Phytoseiidae) on apple trees in Finland. Ann. Agric. Fenn., 27: 305-314.

MacPhee, A.W., 1963. The effect of low temperatures on some predaceous phytoseiid mites, and on the brown mite Bryobia arborea M. \& A. Can. Entomol., 95: 41-44.

Miedema, E., 1987. Survey of phytoseiid mites (Acari: Phytoseiidae) in orchards and surrounding vegetation of north-western Europe, especially in the Netherlands. Keys, descriptions and figures. Neth. J. Pl. Path. Suppl., No 2: 1-64.

Overmeer, W.P.J. and van Zon, A.Q., 1983. Resistance to parathion in the predacious mite Typhlodromus pyri Scheuten (Acarina: Phytoseiidae). Meded. Fac. Landbouwwet. Rijksuniv. Gent, 43: 247-251.

Sabelis, M.W. and Dicke, M., 1985. Long-range dispersal and searching behaviour. In: Helle, W. and Sabelis, M.W. (Eds.) World Crop Pests. Spider mites. Part 1 B., pp. 141-160. Elsevier, Amsterdam.

Schausberger, P., 1991. Vergleichende Untersuchungen zum Lebensverlauf, die Erstellung von Lebenstafeln und die Vermehrungskapazität von Amblyseius aberrans Oud. und Amblyseius finlandicus Oud. (Acari: Phytoseiidae). Pflanzenschutzberichte, 52: 53-71.

Thistlewood, H.M.A., 1991. A survey of predatory mites in Ontario apple orchards with diverse pesticide programs. Can. Entomol., 123: 1163-1174.

Trapman, M., 1989. Integrierte Bekämpfung von Roter Spinne und Rostmilben im Obstbau holländische Erfahrungen. Besseres-Obst, 34: 1, 8-10. 
10

Tuovinen, T. and Rokx, J.A.H., 1991. Phytoseiid mites (Acari: Phytoseiidae) on apple trees and in surrounding vegetation in southern Finland. Densities and species composition. Exp. \& Appl. Acarol., 12: 35-46.

Wildbolz, T. and Staub, A., 1986. Raubmilbenansiedlung im Obstbau. Schweiz. Z. Obst-Weinbau, 122: $483-488$. 


\section{TABLE 1.}

Surveyed orchards in 1989. Pesticide treatments and sampled adjacent plants.

\begin{tabular}{|c|c|c|c|c|c|c|}
\hline \multirow{2}{*}{$\begin{array}{l}\text { Orchard, } \\
\text { location }\end{array}$} & \multirow{2}{*}{$\begin{array}{l}\text { Sampl. } \\
\text { date }\end{array}$} & \multicolumn{3}{|c|}{$\begin{array}{c}\text { Pesticide treatments } \\
\text { (no. of sprays; days elapsed to sampling) }\end{array}$} & \multicolumn{2}{|l|}{ Adjacent vegetation } \\
\hline & & Insecticide $^{1}$ & Acaricide $^{2}$ & Fungicide $^{3}$ & Species & Coeff: ${ }^{4}$ \\
\hline 1. Lohja & 9.8 . & $\begin{array}{l}\operatorname{azin}(1 ; 45) \\
\operatorname{oxyd}(1 ; 89)\end{array}$ & $\operatorname{chin}(1 ; 45)$ & $\begin{array}{l}\text { bite }(3 ; 70) \\
\text { dith }(4 ; 29)\end{array}$ & Acer platanoides L. & 10 \\
\hline 2. Lohja & 9.8 & oxyd $(1 ; 86)$ & $\operatorname{chin}(1 ; 27)$ & $\begin{array}{l}\operatorname{dith}(5 ; 27) \\
\text { trif }(4 ; 54)\end{array}$ & $\begin{array}{l}\text { Aesculus hippocastanum } \mathrm{L} \text {. } \\
\text { Pyrus communis } \mathrm{L} \text {. }\end{array}$ & $\begin{array}{r}10 \\
1\end{array}$ \\
\hline 3. Lohja & 9.8 & oxyd( $1 ; 85)$ & $\operatorname{dico}(1 ; 76)$ & $\begin{array}{l}\operatorname{dith}(6 ; 28) \\
\operatorname{trif}(2 ; 101)\end{array}$ & $\begin{array}{l}\text { Alnus sp. } \\
\text { Fraxinus excelsior L. } \\
\text { Rosa majalis Herrm. } \\
\text { Salix sp. }\end{array}$ & $\begin{array}{c}1 \\
10 \\
0.2 \\
0.2\end{array}$ \\
\hline 4. Lohja & 10.8 & $\begin{array}{l}\operatorname{azin}(1 ; 53) \\
\operatorname{oxyd}(2 ; 69)\end{array}$ & - & $\begin{array}{l}\text { bite }(1 ; 53) \\
\operatorname{dith}(1 ; 63) \\
\text { trif }(2 ; 69)\end{array}$ & $\begin{array}{l}\text { Prunus cerasus } \mathrm{L} .5 \\
\text { Prunus domestica } \mathrm{L} .\end{array}$ & $\begin{array}{l}1 \\
1\end{array}$ \\
\hline 5. Lohja & 10.8 & $\operatorname{azin}(1 ; 54)$ & $\operatorname{chin}(1 ; 54)$ & bite $(5 ; 54)$ & $\begin{array}{l}\text { Crataegus coccinea hort. } \\
\text { Prunus padus } \mathrm{L} . \\
\text { Tilia cordata } \text { Mill. }\end{array}$ & $\begin{array}{c}0.2 \\
1 \\
20\end{array}$ \\
\hline 6. Aland & 17.8 & $\begin{array}{l}\operatorname{azin}(2 ; 34) \\
\operatorname{dime}(2 ; 66) \\
\operatorname{oxyd}(1 ; 66)\end{array}$ & - & $\begin{array}{l}\operatorname{bite}(2 ; 73) \\
\operatorname{dich}(2 ; 73) \\
\operatorname{dith}(2 ; 34) \\
\operatorname{trif}(1 ; 100)\end{array}$ & none & \\
\hline 7. Aland & 17.8 & $\begin{array}{l}\operatorname{azin}(1 ; 66) \\
\operatorname{dime}(1 ; 51)\end{array}$ & - & $\begin{array}{l}\operatorname{bite}(1 ; 94) \\
\operatorname{dich}(1 ; 31) \\
\operatorname{dith}(6 ; 38)\end{array}$ & Corylus avellana L. & 0.2 \\
\hline 8. Aland & 17.8 & $\begin{array}{l}\operatorname{azin}(1 ; 73) \\
\operatorname{dime}(3 ; 59)\end{array}$ & $\operatorname{chin}(2 ; 21)$ & $\operatorname{dith}(6 ; 35)$ & $\begin{array}{l}\text { P. domestica } \\
\text { Sorbus sp. }\end{array}$ & $\begin{array}{l}1 \\
1\end{array}$ \\
\hline 9. Aland & 17.8 & $\operatorname{azin}(2 ; 62)$ & $\begin{array}{l}\operatorname{chin}(1 ; 37) \\
\text { chlo }(1 ; 29)\end{array}$ & bite $(6 ; 29)$ & $\begin{array}{l}\text { P. cerasus } \\
\text { Ulmus glabra Huds. }\end{array}$ & $\begin{array}{c}1 \\
20\end{array}$ \\
\hline 10. Aland & 17.8 & $\begin{array}{l}\operatorname{azin}(1 ; 28) \\
\operatorname{dime}(2 ; 48)\end{array}$ & $\operatorname{chin}(1 ; 34)$ & $\begin{array}{l}\text { bite }(3 ; 28) \\
\operatorname{copp}(1 ; 114) \\
\operatorname{dich}(2 ; 72) \\
\operatorname{dith}(2 ; 48)\end{array}$ & $\begin{array}{l}\text { A. hippocastanum } \\
\text { Ribes uva-crispa } \mathrm{L} . \\
\text { Sambucus racemosa } \mathrm{L} \text {. }\end{array}$ & $\begin{array}{c}10 \\
0.2 \\
0.2\end{array}$ \\
\hline 11. Piikkiō & 25.8 & oxyd( $1 ; 87)$ & $\operatorname{chin}(2 ; 36)$ & bite $(6 ; 44)$ & $\begin{array}{l}\text { Cornus alba } \mathrm{L} . \\
\text { Ribes nigrum } \mathrm{L} . \\
\text { Rubus sp. } \\
\text { Sorbus sp. }\end{array}$ & $\begin{array}{l}0.2 \\
0.2 \\
0.2 \\
1\end{array}$ \\
\hline 12. Bromarv & 31.8 & $\operatorname{oxyd}(1 ;>100)$ & $\begin{array}{l}\operatorname{dico}(1 ; 70) \\
\operatorname{pine}(2 ; 47)\end{array}$ & $\begin{array}{l}\operatorname{bite}(1 ;>80) \\
\operatorname{dich}(1 ;>80) \\
\operatorname{dith}(9 ;>45)\end{array}$ & $\begin{array}{l}\text { A. platanoides } \\
\text { Alnus glutinosa (L.) } \\
\text { Rubus idaeus L. } \\
\text { Sorbus aucuparia L. }\end{array}$ & $\begin{array}{l}10 \\
1 \\
0.2 \\
1\end{array}$ \\
\hline 13. Pohja & 6.9. & $\operatorname{azin}(2 ; 65)$ & $\operatorname{chin}(1 ; 96)$ & $\begin{array}{l}\operatorname{bite}(2 ; 51) \\
\operatorname{dith}(5 ; 65)\end{array}$ & $\begin{array}{l}C . \text { avellana } \\
R . \text { nigrum }\end{array}$ & $\begin{array}{l}0.2 \\
0.2\end{array}$ \\
\hline 14. Pohja & 6.9. & $\operatorname{dime}(1 ; 123)$ & flub( $1 ; 106)$ & $\operatorname{dith}(9 ; 47)$ & $\begin{array}{l}\text { P. padus } \\
\text { Rubus odoratus } \mathrm{L} . \\
\text { U. glabra }\end{array}$ & $\begin{array}{l}1 \\
0.2 \\
20\end{array}$ \\
\hline
\end{tabular}

'Insecticides: azinphosmethyl, dimethoate, oxydemetonmethyl.

${ }^{2}$ Acaricides: chinomethionate, chlorbenzilate, dicofol, fenson, flubenzimine, pine-oil soap.

${ }^{3}$ Fungicides: bitertanol, copperoxychloride, dichlofluanid, dithianon, triforine.

${ }^{4}$ Coefficient based on the approximate size of plants (e.g. $0.2=1 / 5$ the size of normal apple tree)

${ }^{5}$ Sprayed with oxydemetonmethyl. 
TABLE 2.

Composition of all identified specimens of phytoseiids on apple trees and adjacent plants at 14 orchards in August-September, $1989(\mathrm{n}=1711)$.

FAMILY PHYTOSEIIDAE Berlese

$\%$ of each species of Phytoseiidae on

\begin{tabular}{lll}
\hline $\begin{array}{l}\text { Unsprayed } \\
\text { apple }\end{array}$ & $\begin{array}{l}\text { Sprayed } \\
\text { apple }\end{array}$ & $\begin{array}{l}\text { Other } \\
\text { plants }\end{array}$ \\
$(n=737)$ & $(n=203)$ & $(n=771)$
\end{tabular}

Subfamily Phytoseiinae Berlese

Phytoseius Ribaga

Phytoseius macropilis (Banks)

67.1

30.1

24.7

Seiulus Berlese

Seiulus aceri (Collyer)

0.0

0.0

1.1

Paraseiulus Muma

Paraseiulus soleiger (Ribaga)

$1.0 \quad 8.5$

$\begin{array}{ll}8.5 & 0.9\end{array}$

Paraseiulus triporus (Chant \& Shaul)

0.4

5.7

1.7

Anthoseius De Leon

Anthoseius richteri (Karg)

Anthoseius rhenanus (Oudemans)

0.3

0.0

0.4

0.4

0.0

10.6

Typhlodromus Scheuten

Typhlodromus laurae Arutunjan

0.0

0.0

0.1

Subfamily Amblyseiinae Berlese

Euseius Wainstein

Euseius finlandicus (Oudemans)

30.8

53.5

60.5

Amblyseius Berlese

Amblyseius reductus Wainstein

0.0

2.2

0.1

${ }^{1)}$ Only part of specimens collected on other plants were identified. 
TABLE 3.

Densities of phytoseiid mites on unsprayed apple trees and on adjacent trees and bushes (1989-1991).

Phytoseiid mites/100 leaves

\begin{tabular}{|c|c|c|c|}
\hline & & & \\
\hline Plant species & Mean & $\pm \mathrm{SE}$ & No. of samples \\
\hline Apple (Malus $x$ domestica Borkh.) & 130.0 & 20.1 & 28 \\
\hline Acer platanoides & 26.8 & 10.5 & 4 \\
\hline Aesculus hippocastani & 1062.7 & 463.9 & 3 \\
\hline Alnus spp. & 1.3 & 0.7 & 3 \\
\hline Betula spp. ${ }^{1)}$ & 0.0 & - & 4 \\
\hline Corylus avellana & 288.3 & 106.7 & 8 \\
\hline Crataegus coccinea & 21.0 & 0.6 & 3 \\
\hline Fraxinus excelsior & 254.0 & 160.3 & 3 \\
\hline Prunus padus & 46.2 & 25.1 & 5 \\
\hline Quercus robur & 122.3 & 3.9 & 3 \\
\hline Ribes nigrum & 67.9 & 57.7 & 8 \\
\hline Ribes rubrum $\mathrm{L}^{1}{ }^{1)}$ & 30.3 & 13.5 & 11 \\
\hline Rubus idaeus & 29.9 & 17.0 & 7 \\
\hline Salix spp. & 30.6 & 14.7 & 5 \\
\hline Sorbus spp. & 126.4 & 60.5 & 5 \\
\hline Tilia spp. & 122.0 & 30.7 & 7 \\
\hline Ulmus glabra & 115.0 & 68.0 & 2 \\
\hline
\end{tabular}

${ }^{1)}$ Not included in samples in 1989 
Phytoseiid mites on apple and adjacent trees and bushes in 14 orchards, 1989. (Cf. the phytoseiid species list in Table 2 and the plant species list in Table 1).

Number of phytoseiids/100 leaves ${ }^{1)}$

Unsprayed apple Sprayed apple Surrounding trees and bushes (unsprayed)

Orch.

Phytoseiid " Phytoseiid

no.

species $\mathbf{n}$

Phytosenid
species

nas

\section{GROUP 1}

5.

\section{GROUP 2}

7.

9.

10.

12.

\begin{tabular}{|c|c|c|c|c|}
\hline P.macr & 28 & P.macr & 2 & A. hippocastanum \\
\hline E.finl & 1 & E.finl & 2 & P. communis \\
\hline P.macr & 4 & - & 0 & C. avellana \\
\hline A.rhen & 1 & & & \\
\hline \multirow[t]{2}{*}{-} & & A.redu & 1 & $P$. cerasus \\
\hline & & E.finl & 1 & U. glabra \\
\hline \multirow[t]{3}{*}{-} & & - & 0 & A. hippocastanum \\
\hline & & & & R. uva-crispa \\
\hline & & & & S. racemosa \\
\hline P.macr & 118 & A.rhen & 1 & A. platanoides \\
\hline E.finl & 49 & & & A. glutinosa \\
\hline P.sole & 2 & & & R. idaeus \\
\hline A.rhen & 1 & & & S. aucuparia \\
\hline
\end{tabular}

\section{GROUP 3}

\begin{tabular}{|c|c|c|c|c|c|c|c|}
\hline 1. & $\begin{array}{l}\text { P.macr } \\
\text { P.trip }\end{array}$ & $\begin{array}{r}135 \\
3\end{array}$ & P.macr & 2 & A. platanoides & 20 & S.acer,E.finl \\
\hline \multirow[t]{4}{*}{3.} & - & & - & 0 & Alnus sp. & 0 & - \\
\hline & & & & & F. excelsior & 28 & E.finl \\
\hline & & & & & Rosa sp. & 0 & - \\
\hline & & & & & Salix sp. & 1 & E.finl \\
\hline \multirow[t]{2}{*}{4.} & - & & E.finl & 1 & P. cerasus & 3 & A.rhen,E.finl \\
\hline & & & & & P. domestica & 0 & - \\
\hline \multirow[t]{2}{*}{8.} & - & & - & 0 & P. domestica & 0 & - \\
\hline & & & & & Sorbus sp. & 0 & - \\
\hline 6. & E.finl & 59 & - & 0 & - & & \\
\hline \multirow[t]{3}{*}{13.} & P.macr & 125 & E.finl & 0.5 & C. avellana & 4 & E.finl \\
\hline & E.finl & 71 & P.sole & 0.5 & R. nigrum & 5 & E.finl \\
\hline & A.rich & 2 & & & & & \\
\hline
\end{tabular}

$\begin{array}{lclrl}\text { P.sole } & 8.3 & \text { C. coccinea } & 22 & \text { E.finl } \\ \text { P.macr } & 1.3 & \text { P. padus } & 9 & \text { E.finl } \\ \text { E.finl } & 1 & \text { T. cordata } & 73 & \text { E.finl,A.rhen,P.sole } \\ \text { E.finl } & 52 & \text { C. alba } & 77 & \text { E.finl } \\ \text { P.macr } & 31 & \text { R. nigrum } & 469 & \text { E.finl,P.sole,P.macr,T.laur } \\ \text { P.trip } & 7 & \text { Rubus sp. } & 3 & \text { P.macr,E.finl } \\ \text { P.sole } & 2 & \text { S. thuringiaca } & 111 & \text { E.finl,P.sole,P.macr } \\ \text { A.redu } & 1 & & & \\ \text { E.finl } & 16.3 & \text { P. padus } & 141 & \text { E.finl,P.macr } \\ \text { P.macr } & 4.3 & \text { R. odoratus } & 272 & \text { E.finl,P.trip } \\ \text { P.sole } & 0.7 & \text { U. glabra } & 47 & \text { E.finl,P.sole,P.trip } \\ \text { P.trip } & 0.7 & & & \end{array}$

\section{E.finl}

1 E.finl

153 P.macr,P.trip,P.sole

4 P.macr,E.finl,P.trip

183 P.macr,A.redu

1440 E.finl,P.trip,P.macr

4 E.finl,P.trip

0 -

0 -

2 A.rhen

15 A.rhen

334 A.rhen,P.macr,E.finl, A.richt,P.sole

\section{S.acer,}

Plant species n $\quad$ species present ${ }^{2}$


TABLE 5.

Densities of phytoseiid mites and prey mites (spider mites and tydeid mites) on apple trees and on adjacent trees in a 2 ha apple orchard. Samples were taken on August 6, 1991, from trees in northern (N), eastern (E), and western (W) parts of the orchard. All apple trees were sprayed with dithianon (11 sprays, the last spray on July 1), chinomethionate (June 12) and dimethoate (July 22). (Cf. the phytoseiid species list in Table 2).

\begin{tabular}{|c|c|c|c|c|c|c|}
\hline \multirow[b]{2}{*}{ Sample } & \multirow{2}{*}{$\begin{array}{l}\text { Phytoseiid } \\
\text { species }\end{array}$} & \multicolumn{3}{|c|}{ Phytoseiid mite numbers } & \multirow{2}{*}{$\begin{array}{c}\text { Prey } \\
\text { density } \\
\text { /leaf }\end{array}$} & \multirow{2}{*}{$\begin{array}{l}\text { Pred : } \\
\text { prey }\end{array}$} \\
\hline & & heaf & /gram & /plant ${ }^{1}$ & & \\
\hline Apple (N) & E.finl,P.macr & 3.12 & 4.46 & 11200 & $3.58^{2}$ & $1: 1.15$ \\
\hline Apple (E) & E.finl,P.macr & 1.85 & 2.68 & 6700 & $0.97^{2}$ & $1: 0.52$ \\
\hline Apple (W) & E.finl,P.macr & 0.32 & 0.44 & 1100 & $0.89^{2}$ & $1: 2.78$ \\
\hline Corylus avellana $(\mathrm{E}, \mathrm{N})$ & E.finl,P.macr & 9.82 & 21.35 & 10800 & 1.39 & $1: 0: 14$ \\
\hline Lonicera xylosteum L. (N) & E.finl,A.redu,P.macr & 2.66 & 14.0 & 3500 & 0.02 & $1: 0.01$ \\
\hline Tilia cordata $(\mathrm{E})$ & E.finl & 2.42 & 2.95 & 147500 & 0.78 & $1: 0.36$ \\
\hline Quercus robur $(\mathrm{N})$ & E.finl & 1.17 & 2.93 & 146500 & 0.3 & $1: 0.26$ \\
\hline Salix sp. (W) & P.macr,E.finl,P.sole & 0.8 & 0.77 & 200 & 0.04 & $1: 0.05$ \\
\hline Prumus padus $(\mathrm{W})$ & E.finl & 0.25 & 0.86 & 2200 & 1.26 & $1: 5.04$ \\
\hline
\end{tabular}

${ }^{1}$ Estimated fresh weights of all leaves of one average plant in the area: apple $2.5 \mathrm{~kg}$, C. avellana $0.5 \mathrm{~kg}$, Salix sp. $0.5 \mathrm{~kg}, P$. padus $2.5 \mathrm{~kg}$, L. xylosteum $0.25 \mathrm{~kg}, Q$. robur $50 \mathrm{~kg}, T$. cordata $50 \mathrm{~kg}$.

${ }^{2}$ Primarily P. ulmi. Mean no. of $P$. ulmi winter eggs in November 1991 was $2.6 / 10 \mathrm{~cm}$ in twig samples taken randomly from the whole orchard. 



\title{
CHEMICAL CONTROL OF EUROPEAN RED SPIDER MITE PANONYCHUS ULMI (KOCH). I. EVALUATION OF FLUBENZIMINE
}

\author{
TUOMO TUOVINEN
}

Tuovinen, T. 1989. Chemical control of European red spider mite Panonychus ulmi (Koch). I. Evaluation of flubenzimine. Ann. Agric. Fenn. 28: 317-333. (Agric. Res. Centre, Inst. PI. Protect., SF-31600 Jokioinen, Finland.)

Good control of $P$. ulmi was achieved with flubenzimine $(150-250 \mathrm{~g}$ a.i./100 I water, $0.45-0.75 \mathrm{~kg}$ a.i./ha, mistsprayer $300-400 \mathrm{l} / \mathrm{ha}$ ) when sprayed just before or during blossom and, if necessary, in late June or July. If sprayed only once, the recommended time for spraying in spring is when the effective temperature sum of 200 dd above $+5{ }^{\circ} \mathrm{C}$ has been reached. A high density mite population may need another spray later in July. Later treatments result in a low overwintering population, facilitating mite control also in the next season. When sprayed in low concentrations (25-85 g a.i./100 I water) several times, almost complete control of $P$. ulmi was achieved. Flubenzimine was also effective against the apple rust mite Aculus schlechtendali. It had a harmful effect on predatory phytoseiid mites and one spray diminished the number of phytoseiids by more than $90 \%$; when flubenzimine was sprayed several times during the season, phytoseiids disappeared almost entirely. Flubenzimine reduced the number of spiders (Araneida) but had only slight effect on the numbers of predatory anthocorid bugs.

The reference acaricides chinomethionate $(37.5-62.5 \mathrm{~g}$ a.i./100 I water, $0.12-0.22$ $\mathrm{kg} \mathrm{a.i./ha),} \mathrm{dicofol} \mathrm{(140} \mathrm{g} \mathrm{a.i./100} \mathrm{I} \mathrm{water,} 0.4 \mathrm{~kg}$ a.i./ha), fenbutatinoxide ( $250 \mathrm{~g} \mathrm{a.i./}$ 1001 water, $0.75 \mathrm{~kg}$ a.i./ha) and oxydemetonmethyl (132 g a.i./100 I water, $0.4 \mathrm{~kg}$ a.i./ha) were generally not as effective as flubenzimine. In most cases, satisfactory control can be achieved also by these compounds, but often two or even three treatments are then necessary.

Index words: chinomethionate, dicofol, fenbutatinoxide, flubenzimine, oxydemetonmethyl, acaricides, European red spider mite, Panonychus ulmi, Phytoseiidae.

\section{INTRODUCTION}

The European red spider mite (ERM), Panonychus ulmi (Koch), has become a more serious pest on commercially grown apple trees in Finland. The ERM control strategy with regard to chemical control, is to lower the population in the spring before the beginning of fruit development either by early spring sprays with ovicidal oil preparates, pre-blossom sprays with organophosphate insecticide oxydemeton- methyl, or pre-blossom and blossom sprays with chinomethionate and dicofol. However, in many cases additional sprays are required in July. Growers are aware of the common demand to reduce pesticide use, but so far, no acaricide has provided good control with a single spray, especially, if the season is warm and favourable for ERM.

Successful biological control methods against 
main insect pests would resolve the major problems in ERM control. In particular, insecticides have adverse effects on phytoseiid mites and other beneficial arthropods (e.g. SwIFT 1968, KARG et al. 1987). In small home gardens where no insecticidal, acaricidal or fungicidal treatments have been carried out, ERM is not a problem. This is mostly due to predatory phytoseiid mites which are common in these orchards (KROPCZYNSKA and TUOVINEN 1988). In Finland, the main insect pest on apple is the apple fruit moth Argyresthia conjugella Zell., which is controlled by spraying broad-spectrum insecticides. Studies on the integrated control of the apple fruit moth are in progress, but before any successful methods are available, the use of acaricides against ERM will continue. The most common acaricides, chinomethionate and dicofol, have been also found to have harmful effect on phytoseiids (HASSAN et al. 1987).
Effective, yet safer for natural enemies, acaricides would be of great importance in Finnish conditions where apple gardens are quite small and surrounded by wild herbaceous trees and bushes from which predators may easily move to apple trees. Flubenzimine, which acts as a chitin synthesis inhibitor (ZoEBelein et al. 1979), is an interesting acaricide owing to a different mode of action compared to that of earlier acaricides. In some earlier tests, flubenzimine has proved to be quite harmless to beneficial insects and predatory mites, thus supporting possible use of the compound in intergrated control (BONEss 1983). Chinomethionate, dicofol or oxydemetonmethyl were included in tests. The aim of this study is to combine the results of the field tests with flubenzimine and to summarize the situation of ERM control in Finland.

\section{MATERIAL AND METHODS}

Flubenzimine was used as $50 \%$ WP formulation Cropotex, produced by Bayer.

As reference products, chinometionate as $25 \%$ WP formulation (Morestan, Bayer), dicofol as $18.5 \%$ WP formulation (Kelthane, Rohm and Haas), fenbutatinoxide as $50 \%$ WP formulation (Torque, Shell) and oxydemetonmethyl as $26.5 \%$ liquid formulation (Metasystox, Bayer) were used. Sprays were carried out using the recommended concentrations and doses.

\section{Experimental orchards}

Experiments were carried out in four orchards in 1981-88. Two of the orchards were commercial cultivations where insecticidal and fungicidal sprays were performed, too.

Pohja 1981-84. A commercial orchard comprising 7 ha of apple trees. The location is situ- ated near the southern coast. The experimental area was 0.5 ha and the main cultivar 'Lobo'. The area was divided into 6 two-row sectors, each including about 60 trees. 10 trees per sector were randomly chosen for sampling leaves and twigs. Treatments were carried out by a tractor-driven mistsprayer (Hardi). Some insecticidal and fungicidal sprays were performed in 1982-1984. The nearest meteorological station is Salo $(36 \mathrm{~km})$.

Pälkäne 1982-86. The experimental area, consisting of 100 apple trees (cv. Huvitus), was part of the Häme Research Station orchard. A randomized block design with four 4-tree replicates and untreated shelter trees between treatments was used in 1982 and 1986, in 1983-84 the single tree replicates $(3-12)$ employed were arranged in groups according to the treatments in the previous year. Treatments were done with a knapsack mistsprayer (Solo). A 
meteorological station is situated $0.3 \mathrm{~km}$ from the experimental area.

Bromarv 1986. An experiment was carried out in a commercial orchard using two 1 ha blocks. Sprays were performed using a tractordriven mistsprayer, and insecticidal and fungicidal sprays were also carried out.

Jokioinen 1988. An experiment in an experimental orchard was performed using fully randomized design and single trees as replicates. Sprays were done with a knapsack compression sprayer and a knapsack mistsprayer.

\section{Sampling and observations}

Normally, sampling was carried out by collecting 5-10 spur leaves/tree, from 10-20 trees per treatment, selected randomly from each tree from the same height (1.5-2 m). Sampling was performed usually once before spraying and $2-6$ times afterwards. Leaves from each tree were kept separately in plastic bags and stored at $+5{ }^{\circ} \mathrm{C}$ temperature. Numbers of living mobile mites and eggs were counted immediately or after $1-3$ days under a stereo- microscope. During inspection, occurrence of natural enemies was also observed. Samples of twigs were collected to count winter eggs: 5 pieces of $20 \mathrm{~cm} \mathrm{2-3}$ year old branch from $10-20$ trees per treatment were collected in late October and in November.

In 1982, samples of arthropods occurring in trees were collected by beating 10 branches (in 10 trees/treatment) over a sampling net with an opening of $0.1 \mathrm{~m}^{2}$. Samples were preserved in alcohol and studied later.

Monthly effective temperature sums (in daydegrees over $+5{ }^{\circ} \mathrm{C}$ ) were recorded by the nearest weather stations (Figs. 1-2).

The significance of differences between treatments (in Pohja and Pälkäne) was tested by analysis of variance using Duncan's multiple range test (STEEL and TORRIE 1980) on $\log (\mathrm{x}+1)$ transformed data for each checking date both for eggs and mobile stages. In other orchards, the t-test or analysis of variance using Duncan's multiple range test was employed for calculation. All calculations were performed using the SPSSX-statistical package.

\section{MONTHLY EFFECTIVE TEMPERATURE SUMS IN DAY-DEQREES ABOVE + 5 C SALO METEOROLOGICAL STATION, 1981-1984}

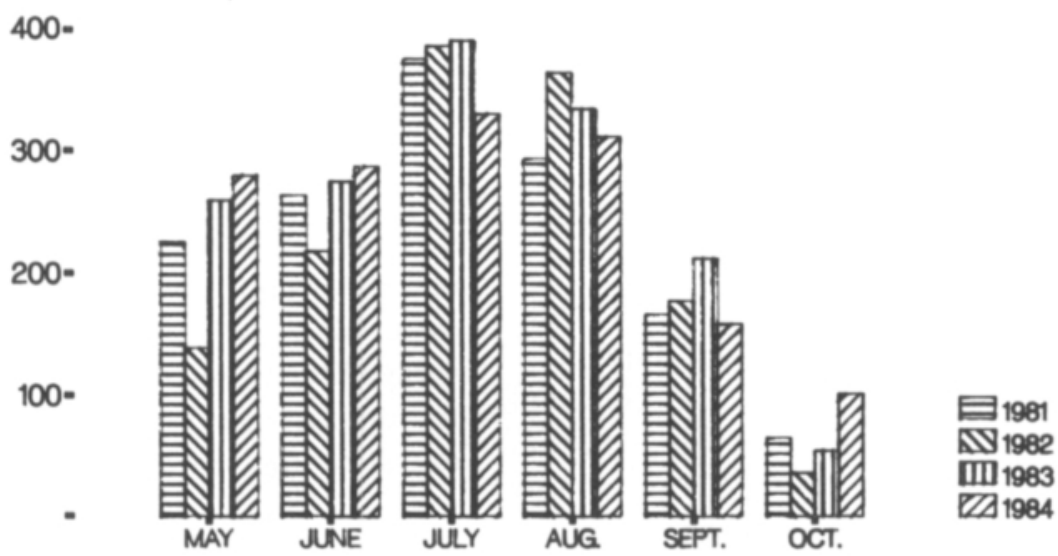

Fig. 1. Monthly effective temperature sums in day-degrees above $+5{ }^{\circ} \mathrm{C}$ at the Salo meteorological station, 1981-1984. 


\section{MONTHLY EFFECTIVE TEMPERATURE SUMS \\ IN DAY-DEGREES ABOVE + 5 C \\ ARG, PAL KANE RESEARCH STATION, 1982-1984, 1986}

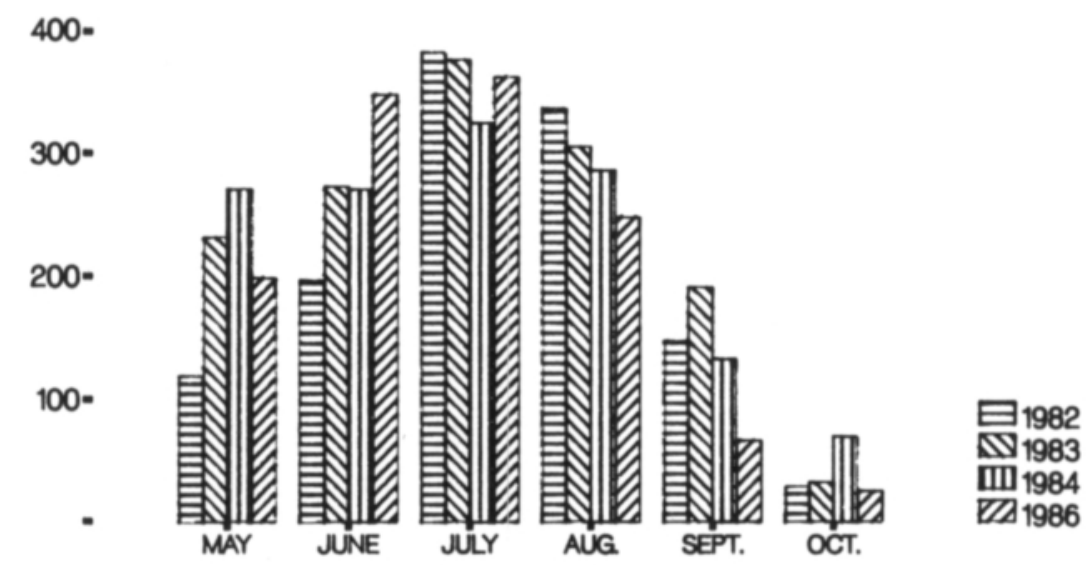

Fig. 2. Monthly effective temperature sums in day-degrees above $+5^{\circ} \mathrm{C}$ at the Pälkäne research station, 1982-1984, 1986.

\section{RESULTS}

\section{Pohja}

Results of the leaf and winter egg counts from Pohja are arranged in a continuous series of experiments to show the yearly changes in mite density after different treatments (Figs. 3a and 3b).

In 1981, two sprays with flubenzimine killed ERM almost completely (block A). One late application (8.7., block C) had a similar effect for the rest of the season. One early spring application (27.5., sprayed when 189 day-degrees above $+5^{\circ} \mathrm{C}$ was reached, block B) had a long lasting effect also although the number of mobile mites was significantly higher than in other trees sprayed with flubenzimine. Chinomethionate (blocks D-F) also had a good effect although the numbers of mobile mites and summer eggs were higher than in respective flubenzimine treated trees. Winter egg counts show that the late application of both acaricides resulted in significantly lower egg numbers than the earlier applications.
In 1982 , block A, sprayed in -81 twice with flubenzimine, was left as a non-treated block because of low ERM density. Although not sprayed, the number of mites did not exceed the control threshold of 10 mites/leaf before September. Flubenzimine was applied once, on 1.6. (140 dd, block B) and on 28.6. (blocks D and F). In block B, ERM density was quite high but one spray was enough to maintain the number of mites under 5/leaf until August. The later applications resulted in almost the same population level in September. Chinomethionate, when sprayed on 1.6. (block E) did not have as good an effect as flubenzimine, although the initial ERM population was lower. In the untreated blocks (A and $\mathrm{C}$ ), which had the late spray with flubenzimine in the previous year, the number of ERM stayed under 10 mobile mites/leaf throughout the whole season.

According to the summer egg counts (Fig. 3b) there were three complete ERM generations in 1982. The effective temperature sum of the 
whole season was $1313 \mathrm{dd}$, which is about the normal rate (mean 1951-1980). In other years, no clear picture of the numbers of generations could be obtained because of fewer inspections.

In 1982, beat samples were collected from each block to check the occurrence of other arthropods. Very few beneficial insects belonging to Heteroptera, Neuroptera or Coleoptera (Coccinellidae) as well as spiders (Araneida) were caught (Table 1). No doubt this is due to a spray with dimethoate against the codling moth Cydia pomonella (L.) and the apple fruit moth Argyresthia conjugella.

In 1983, oxydemetonmethyl was sprayed over the whole experimental area (23.5., 190 dd). Furthermore, one spray with flubenzimine was performed on 26.5. (220 dd, blocks A, D and F). The initial numbers of ERM in each block were quite low and stayed low during June, but ERM densities increased on a very high level in blocks treated only with oxydemetonmethyl. The effect of flubenzimine lasted almost through the whole season, but later in the autumn ERM numbers increased which is expressed in the high numbers of winter eggs. In 1983, September was unusually warm and favourable for ERM egg laying (Fig. 1).

In 1984, only flubenzimine was sprayed over the whole experimental area (24.5., $190 \mathrm{dd}$ ). ERM density remained low, except at the end of the season. The effective temperature sum of the season was higher than normal, $1461 \mathrm{dd}$, favouring ERM reproduction.

\section{Pälkäne}

The results of the experiments in Pälkäne are presented in Tables 3-6. Tables 4 and 5 are arranged so that also the treatments of the previous year are taken into account.

In 1982, the initial ERM population was very uniform in the experimental area (Table 3). The effect of flubenzimine, when sprayed quite late
(29.6.) was satisfactory. The numbers of mobile ERM in untreated blocks did not increase substantially, which may be due to predatory bugs (Heteroptera: Anthocoridae) present in the orchard. The weather was quite cold in 1982, and the effective temperature sum of the whole season was only $1207 \mathrm{dd}$. No sprays with broadspectrum insecticides were performed, but half of the trees were sprayed with diflubenzuron (Dimilin) which did not have any effect on mites during the season except on 2.8., when the number of mobile mites was even higher than in the control trees.

In 1982, beat samples were collected to check the occurrence of other arthropods than mites. Of the beneficial arthropods, Anthocoris spp. was found to be present in all blocks, but not in large numbers (Table 2). Spiders were quite common but flubenzimine clearly diminished their number. The apple sucker Psylla mali (Schmiedb.) (Homoptera: Psyllidae) was the most common insect pest; only a spray with diflubenzuron diminished the number of apple suckers to some extent.

In 1983, ERM numbers were very high in late July, except on trees sprayed the previous year with flubenzimine (Table 4). Flubenzimine, fenbutatinoxide and a pyrethroid insecticide, deltamethrin, were sprayed very late on 29.7 . In trees treated with flubenzimine both in 1982 and 1983, or with fenbutatinoxide in 1983 , ERM density in August and the number of winter eggs were significantly lower than in other blocks. Flubenzimine sprayed on trees with a high density of ERM (block B), while diminishing the number of mobile stages, could not prevent winter egg laying later. The effect of fenbutatinoxide was not as good as that of flubenzimine. Although deltamethrin at first lowered mobile ERM numbers, it later caused a clear outbreak of ERM when winter egg numbers are taken into consideration. The whole season was warm (1404 dd) and especially September was warmer (190 dd) than usual which explains the high winter egg densities. 


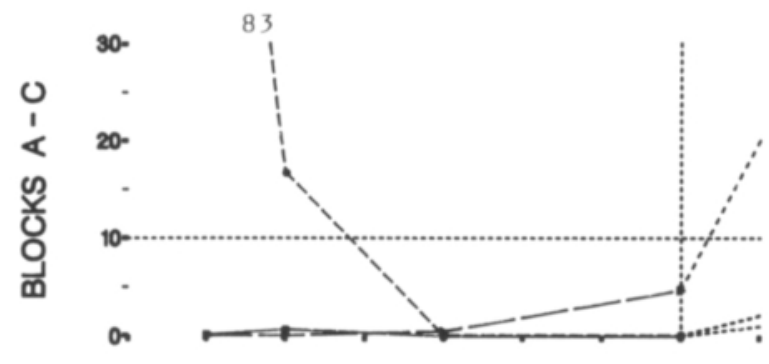

A Flubenzimine (200) 27.5 +

Flubenzimine (150) 87.

$--1-$ B. Flubenzimine (200) 27.5.

D. Chinomethionate (62.5) 27.5. + Chinomethionate (37.5) 8.7

E. Chinomethionate (62.5) 27.5

F. Chinomethionate (37.5) 8.7.

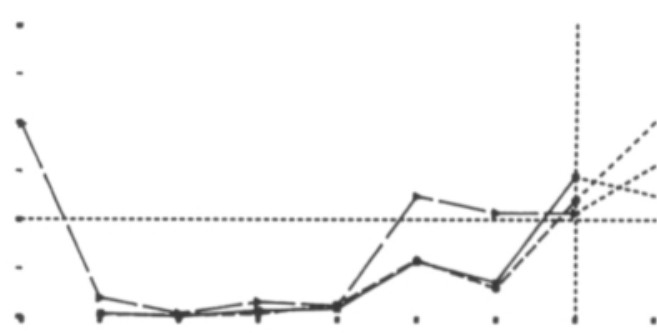

A No treatments

B. Flubenzimine (150) 16.

G No treatments

D. Flubenzimine (150) 28.6.

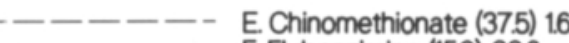

F. Flubenzimine (150) 28.6 .

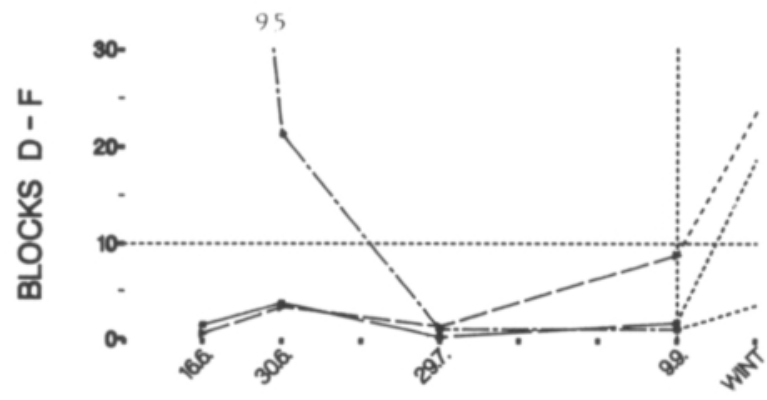

1981

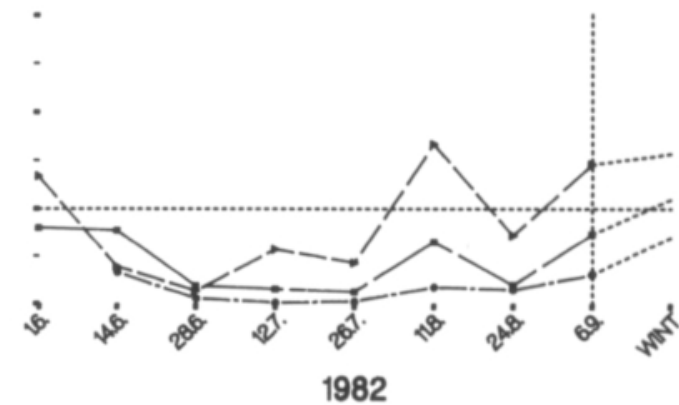

Signif. differences:

$\begin{array}{rlr}1.6 . & N . S . \\ 14.6 . & D>A, C, B, F \\ 28.6 . & E>A, C \\ 12.7 . & D, E>A, C, B, F \\ 26.7 . & E>F, C, B, A, D \\ 11.8 . & E>F, A, B, D, C \\ 24.8 . & E, B>F, D, A, C \\ 6.9 . & B>F, D \\ \text { WINTER } & \text { A,E }>\text { F,D } \\ & \text { C B }>F \\ & \text { C }>F, D\end{array}$

Signif. differences:

16.6.

30.6 .

29.7.

9.9.

WINTER
$\mathrm{F}, \mathrm{C}>\mathrm{B}, \mathrm{A}, \mathrm{E}, \mathrm{D}$

$C, F>B, A, E, D$

$E>A, C, D$,

$F>A, C, D, B$

$B>A, C, F, D$

$E, B, D>F, A, C$ 


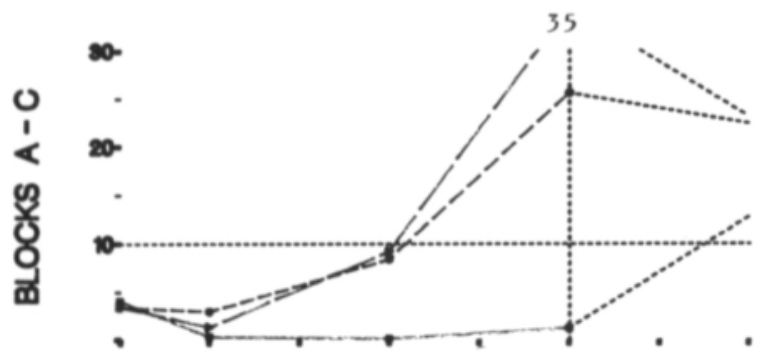

A - F. Oxydemetonmethyl (1325) 235.

A. Fubenzimine (250) 265.

B No other acaricides

G No other acaricides

D. Fubenzimine (250) 265.

- - - E. No other acaricides

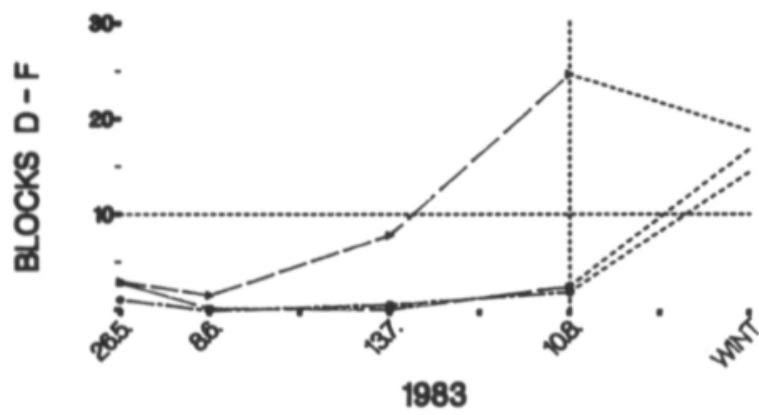

Signif. differences:

26.5 .

8.6.

13.7 .

10.8.

WINTER

$$
\begin{aligned}
A & >F \\
C, E, B & >F, D, A \\
B, C, E & >D, A, F \\
B, E, C & >A, F, D \\
B & >A
\end{aligned}
$$

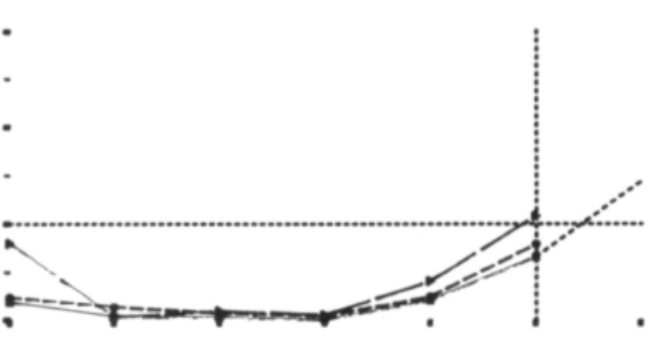

A - F. Flubenzimine (150) 24.5.

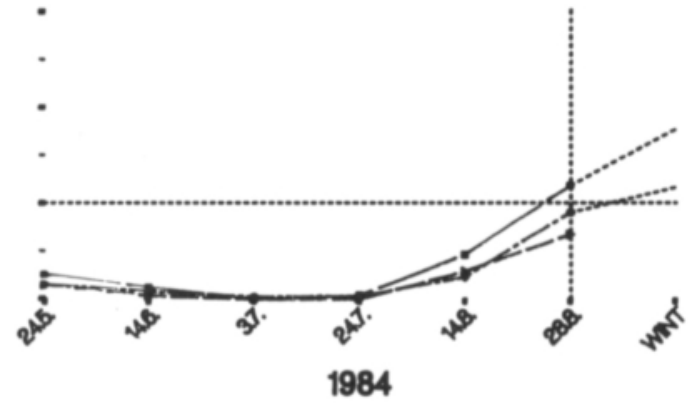

Signif. differences:

\begin{tabular}{|c|c|c|c|c|c|c|c|c|c|c|c|c|c|c|c|c|c|c|c|c|c|c|c|c|}
\hline \multirow[b]{2}{*}{ Treatment: } & \multicolumn{6}{|c|}{ Anthocoridae } & \multicolumn{6}{|c|}{ Neuroptera } & \multicolumn{6}{|c|}{ Araneida } & \multicolumn{6}{|c|}{$\begin{array}{l}\text { Other arthropods } \\
\text { (mites not included) }\end{array}$} \\
\hline & A & B & $\mathrm{C}$ & D & $\mathrm{E}$ & $\mathrm{F}$ & A & B & $\mathrm{C}$ & D & $\mathrm{E}$ & $\mathrm{F}$ & A & B & C & D & $\mathrm{E}$ & $\mathrm{F}$ & A & B & $\mathrm{C}$ & D & E & $\mathrm{F}$ \\
\hline 14.6. & 0 & 1 & 2 & 1 & 2 & 3 & 0 & 0 & 0 & 0 & 0 & 0 & 1 & 1 & 0 & 0 & 1 & 2 & 75 & 36 & 62 & 76 & 31 & 50 \\
\hline 28.6 & 4 & 2 & 0 & 0 & 1 & 0 & 0 & 0 & 0 & 0 & 0 & 0 & 0 & 1 & 1 & 0 & 0 & 0 & 18 & 12 & 7 & 13 & 6 & 9 \\
\hline 26.7. & 1 & 0 & 0 & 0 & 0 & 0 & 0 & 0 & 0 & 0 & 2 & 0 & 0 & 0 & 0 & 0 & 0 & 0 & 5 & 3 & 7 & 3 & 8 & 0 \\
\hline 10.8 & 0 & 0 & 0 & 0 & 0 & 0 & 0 & 0 & 0 & 0 & 0 & 1 & 0 & 1 & 0 & 0 & 0 & 0 & 0 & 6 & 3 & 4 & 43 & 10 \\
\hline 24.8 & 0 & 0 & 0 & 0 & 1 & 0 & 0 & 0 & 0 & 0 & 1 & 4 & 0 & 0 & 1 & 0 & 2 & 3 & 14 & 4 & 12 & 13 & 13 & 9 \\
\hline
\end{tabular}

$\begin{aligned} 24.5 . & \text { B }>\text { A,E,F } \\ 14.6 . & \text { N.S. } \\ 3.7 . & \text { B }>\text { D.E } \\ 24.7 . & \text { N.S. } \\ 14.8 . & \text { D }>\text { A C, F } F \\ 28.8 . & \text { N.S. } \\ \text { WINTER } & \text { D }>\text { F }\end{aligned}$

Table 1. Number of some predatory and other arthropods collected by the beating method in Pohja 1982. Treatment letters refer to Fig. 3. Samples were collected from 10 branches/treatment. 

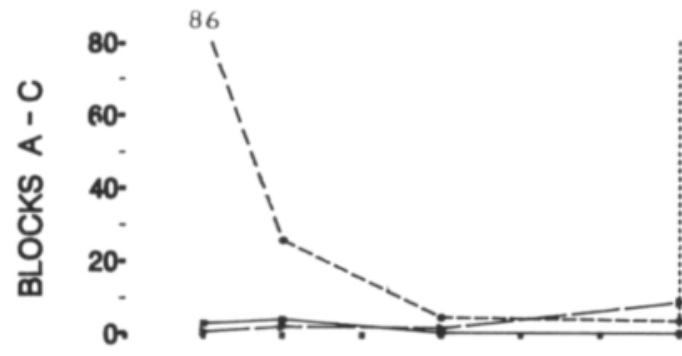

A. Flubenzimine (200) 27.5. +

Flubenzimine (150) 87.

B. Flubenzimine (200) 27.5

G. Flubenzimine (150) 87.

D. Chinomethionate (625) 27.5 .

Chinomethionate (37.5) 87.

- - - - E Chinomethionate (625) 27.5.

F. Chinomethionate (37.5) 87 .

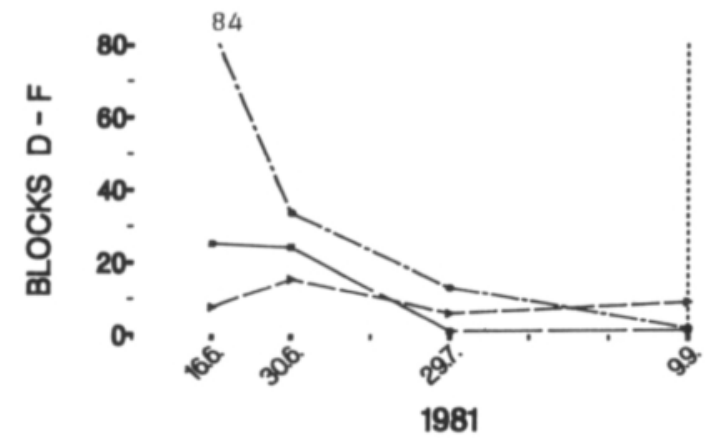

Signif. differences:

16.6.

30.6 .

$$
\begin{aligned}
\mathrm{F}, \mathrm{C} & >\mathrm{B}, \mathrm{A}, \mathrm{E}, \mathrm{D} \\
\mathrm{F} & >\mathrm{B}, \mathrm{A}, \mathrm{E} \\
\mathrm{C}, \mathrm{D} & >\mathrm{B}, \mathrm{A} \\
\mathrm{F} & >\mathrm{A}, \mathrm{D}, \mathrm{B}, \mathrm{C}, \mathrm{E} \\
\mathrm{E} & >\mathrm{A}, \mathrm{D}, \mathrm{B}
\end{aligned}
$$

29.7 .

9.9 .$$
E, B>A, D, C, F
$$

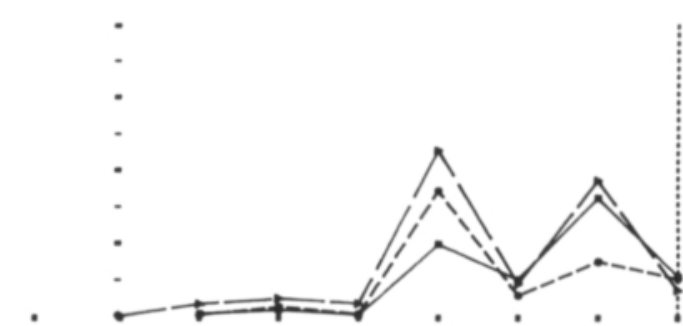

A No treatments

B. Flubenzimine (150) 16.

C. No treatments

D. Flubenzimine (150) 28.6.

E Chinomethionate (37.5) 16.

F. Flubenzimine (150) 286.

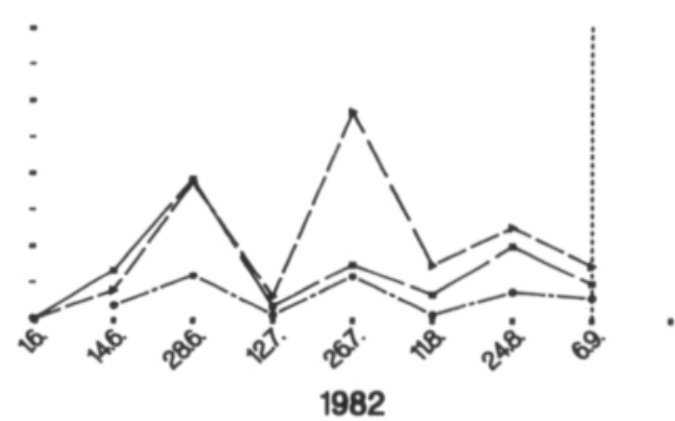

Signif. differences:

$\begin{aligned} 1.6 . & - \\ 14.6 . & \mathrm{D}>\mathrm{C}, \mathrm{A}, \mathrm{B}, \mathrm{F}, \mathrm{E} \\ 28.6 . & \mathrm{E}>\mathrm{C}, \mathrm{A}, \mathrm{A}, \mathrm{C}, \mathrm{B}, \mathrm{F} \\ 12.7 . & \mathrm{E}>\mathrm{A}, \mathrm{C}, \mathrm{B}, \mathrm{F} \\ 26.7 . & \mathrm{B}>\mathrm{F}, \mathrm{F}, \mathrm{A} \\ 11.8 . & \mathrm{E}>\mathrm{F}, \mathrm{C}, \mathrm{D} \\ 24.8 . & \mathrm{B}>\mathrm{F}, \mathrm{B} \\ 6.9 . & \mathrm{B}>\mathrm{F}, \mathrm{C} \\ & \mathrm{E}>\mathrm{F}, \mathrm{B}\end{aligned}$

Fig. 3 b. Results from the field experiments at Pohja 1981-1984. Mean numbers of ERM summer eggs per one leaf. Treatments as in Fig. 3 a. 


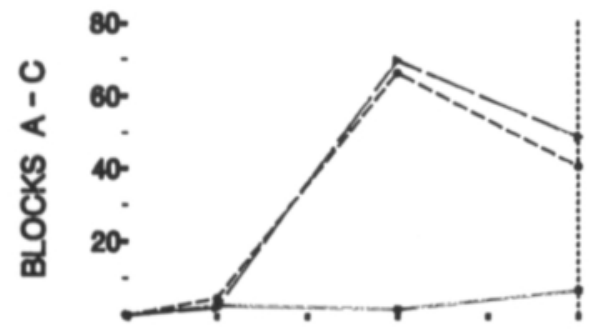

A - F. Oxydemetonmethyl (1325) 235

A Fubenzimine (250) 26.5 .

B No other acaricides

G No other acaricides

Q Fubenzimine (250) 265.

E No other acaricides

_. - . - . . F. Flubenzimine (250) 265

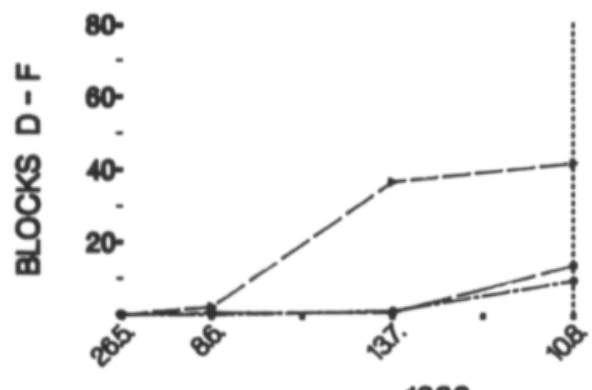

1983

Signif. differences:

26.5.

8.6 .

13.7.

10.8 .

$$
\begin{aligned}
C & - \\
B, C, E & >D, F, A \\
B, C, E & >A, F, D
\end{aligned}
$$

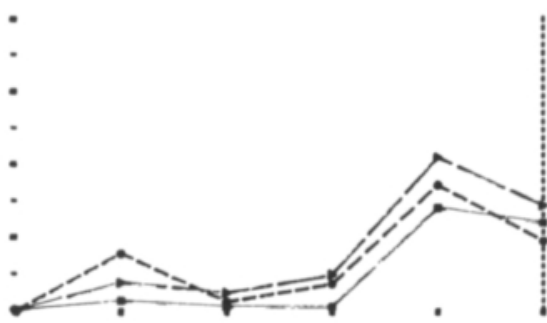

A - F. Flubenzimine (150) 24.5.

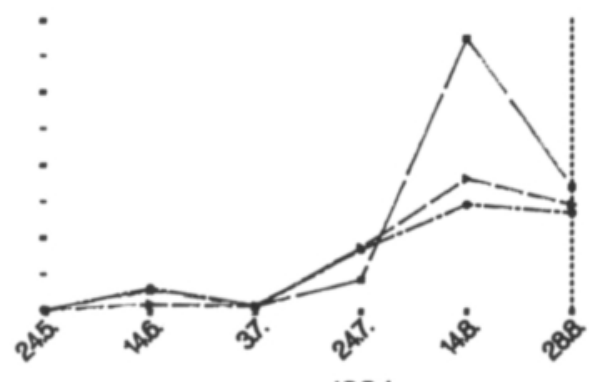

1984

Signif. differences:

24.5 .

14.6.

3.7.

24.7 .

14.8 .

28.8 .

$C>E$

E.F.B. N $>$.S

D $>A, F$

N.S. 

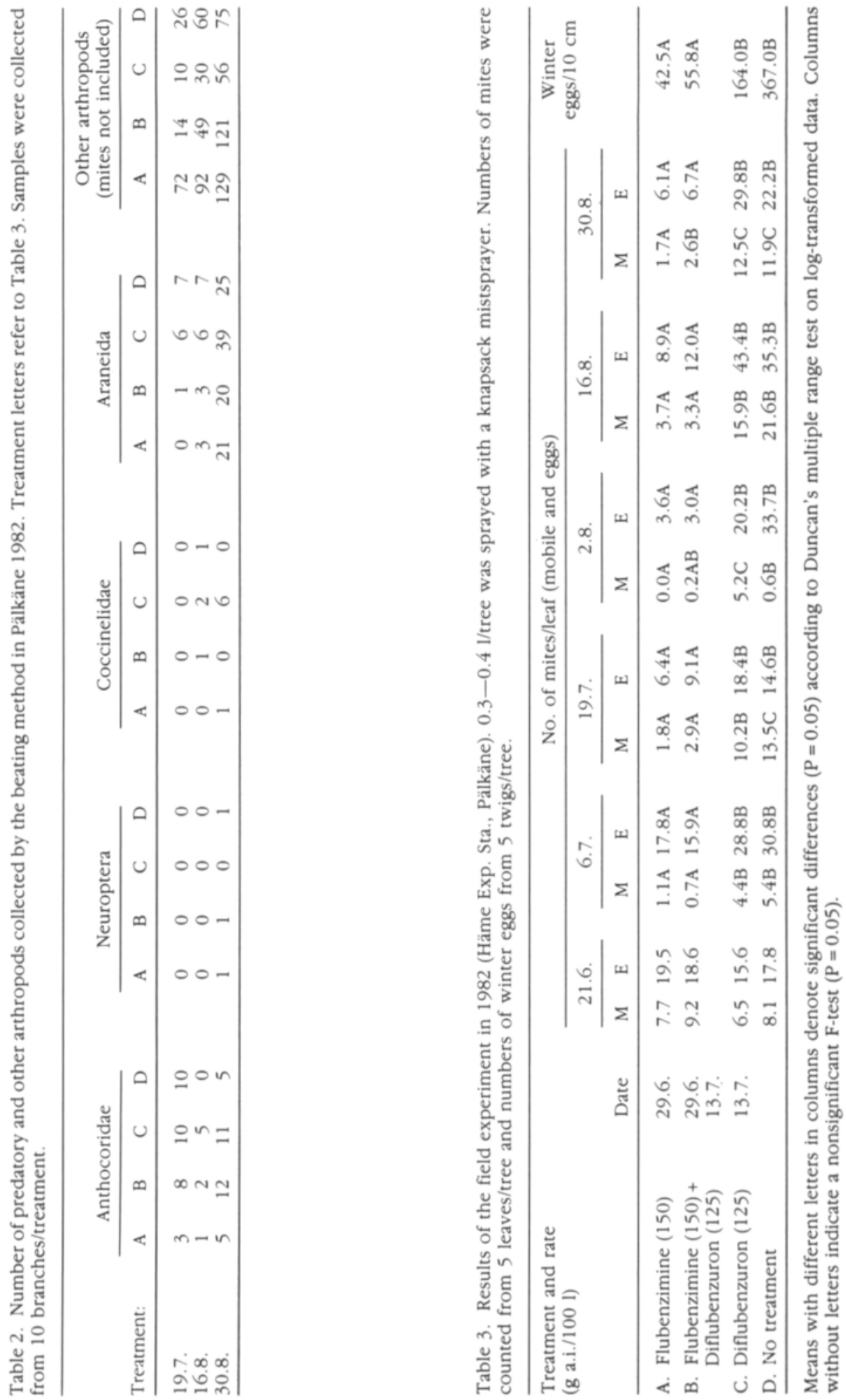
Table 4. Results of the field experiment in 1983 (Häme Res. Sta., Pälkäne). $0.3-0.4 \mathrm{l} /$ tree was sprayed with a knapsack mistsprayer, on 29.7. Numbers of mites were counted from 5 leaves/tree, and numbers of winter eggs from 5 twigs/tree.

\begin{tabular}{|c|c|c|c|c|c|c|}
\hline \multirow{3}{*}{$\begin{array}{l}\text { Treatment and rate } \\
(\mathrm{g} \text { a.i./100 l) }\end{array}$} & \multirow{3}{*}{$\begin{array}{l}\text { Treatm. } \\
\text { in } 1982^{\prime}\end{array}$} & \multicolumn{4}{|c|}{ No. of mites/leaf (mobile and eggs) } & \multirow{3}{*}{$\begin{array}{c}\text { Winter } \\
\text { eggs } / 10 \mathrm{~cm}\end{array}$} \\
\hline & & \multicolumn{2}{|c|}{29.7.} & \multicolumn{2}{|c|}{17.8} & \\
\hline & & M & $\mathrm{E}$ & M & $\mathrm{E}$ & \\
\hline A. Flubenzimine (250) & A & $6 \mathrm{~A}$ & $43 \mathrm{~A}$ & $0.0 \mathrm{~A}$ & $11 \mathrm{~A}$ & $11 \mathrm{~A}$ \\
\hline B. Flubenzimine (250) & - & $44 \mathrm{~B}$ & $249 B$ & $0.7 \mathrm{~A}$ & 106BC & $104 \mathrm{~B}$ \\
\hline C. Fenbutatinoxide (250) & B & $17 \mathrm{~A}$ & $56 \mathrm{~A}$ & $2.8 \mathrm{~A}$ & $39 \mathrm{~A}$ & 196B \\
\hline D. Fenbutatinoxide (250) & - & $71 \mathrm{C}$ & $270 B$ & $1.7 \mathrm{~A}$ & $77 \mathrm{BC}$ & $389 \mathrm{C}$ \\
\hline E. Deltamethrin (2.5) & - & $35 \mathrm{~B}$ & $82 \mathrm{~A}$ & $11.0 \mathrm{~B}$ & $68 \mathrm{C}$ & $675 \mathrm{D}$ \\
\hline F. No treatment & - & $27 \mathrm{~B}$ & $100 \mathrm{~A}$ & $22.0 \mathrm{C}$ & $102 \mathrm{~B}$ & $447 \mathrm{CD}$ \\
\hline
\end{tabular}

Means with different letters in columns denote significant differences $(P=0.05)$ according to Duncan's multiple range test on log-transformed data.

' Letters refer to table 3 ( - indicates untreated trees in 1982).

In 1984, great differences in initial densities among groups of trees were found (Table 5). Except acaricides, the pyrethroids deltamethrin and cyfluthrin, and an insect growth regulator, diflubenzuron, were included to test their effect on the apple fruit moth. All acaricides, sprayed on 11.6. (377 dd) had a good effect on ERM, and only small differences could be found in winter egg counts in the autumn. May was very warm $(270 \mathrm{dd})$ favouring the rapid development of ERM, but in June, soon after the treatments, a colder period began, lasting several weeks. In addition to the sprays, cold weather might have influenced on mite numbers, which later in the season remained quite low in all treatments.

In 1985, the density of ERM was low and no experiments were carried out. In 1986, flubenzimine was sprayed on 17.7. on two areas having different initial ERM densities (Table 6). Flubenzimine had a good effect for the rest of the season and winter egg numbers were very low. Also phytoseiid mites Euseius finlandicus (Oud.) and Phytoseius macropilis (Banks) (Acari: Phytoseiidae) were found to be present in the orchard. In trees sprayed with flubenzimine the number of predatory mites was much lower than that in untreated trees.

\section{Bromarv 1986}

The effect of flubenzimine and chinomethionate was compared in a commercial orchard (Table 7). Flubenzimine was sprayed only once (30.5., $180 \mathrm{dd})$, and chinomethionate three times in May and June (first on 23.5., 147 dd). Neither flubenzimine nor chinomethionate gave satisfactory control of ERM.

\section{Jokioinen 1988}

Flubenzimine was sprayed 5 times timed according to apple scab control sprays to study also the possible effect of sprays on the apple scab. The concentrations were lower than in other experiments, $25-85 \mathrm{~g}$ a.i./100 I water, but the effect of the sprays on ERM was almost complete (Table 8). The initial population density of ERM was low, but predatory mites $E$. finlandicus and $P$. macropilis were numerous. Flubenzimine almost completely killed all mites, including phytoseiids and the apple rust mite Aculus schlechtendali (Nal.) (Acari: Eriophyidae). 


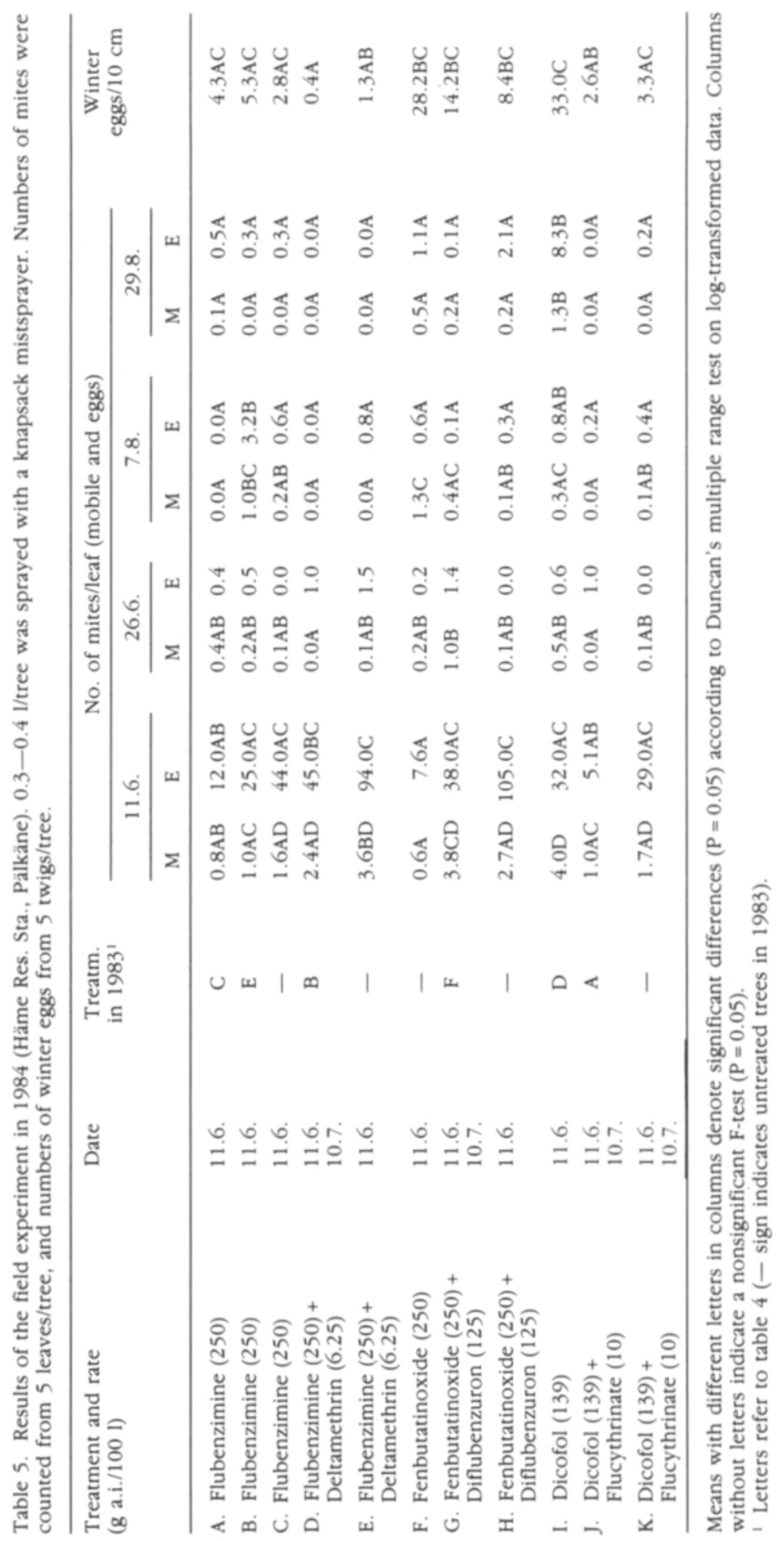


Table 6. Results of the field experiment in 1986 (Häme Res. Sta., Pälkäne). 0.5 1/tree was sprayed on 17.7. with a knapsack mistsprayer, 10 trees/treatment. ERM and phytoseiid numbers were counted from 5 leaves/tree and numbers of winter eggs from 5 twigs/tree. T-test was calculated separately for the two areas with different initial ERM densities.

\begin{tabular}{|c|c|c|c|c|c|c|c|}
\hline \multirow{3}{*}{$\begin{array}{l}\text { Treatment and rate } \\
(\mathrm{g} \text { a.i./100 l) }\end{array}$} & \multicolumn{6}{|c|}{ No. of mites/leaf (mobile and eggs) } & \multirow{3}{*}{$\begin{array}{c}\text { Winter } \\
\text { eggs/10 cm }\end{array}$} \\
\hline & \multicolumn{3}{|c|}{17.7.} & \multicolumn{3}{|c|}{14.8.} & \\
\hline & M & E & Phyt. & M & $\mathrm{E}$ & Phyt. & \\
\hline \multicolumn{8}{|l|}{ Area 1.} \\
\hline A. Flubenzimine $(250)$ & 6.8 & 36.3 & 1.8 & 3.2 & 16.7 & 0.1 & 3.7 \\
\hline B. No treatments & 7.6 & 25.3 & 0.3 & 36.0 & 93.8 & 1.9 & 142.5 \\
\hline $\begin{array}{l}\text { T-test, } P= \\
\text { Area } 2 .\end{array}$ & N.S. & 0.036 & 0.000 & 0.000 & 0.000 & 0.000 & 0.000 \\
\hline A. Flubenzimine (250) & 1.4 & 8.4 & 0.2 & 0.0 & 0.4 & 0.0 & 3.7 \\
\hline B. No treatments & 3.4 & 17.1 & 0.1 & 10.8 & 51.6 & 0.9 & 56.0 \\
\hline T-test, $\mathrm{P}=$ & 0.000 & 0.003 & N.S. & 0.000 & 0.000 & 0.013 & 0.000 \\
\hline
\end{tabular}

Table 7. Results of the field experiment in 1986 (commercial orchard, Bromarv). Blocks of about 1 ha were sprayed with tractor driven mistsprayer (Hardi), $400 \mathrm{l} / \mathrm{ha}$. Numbers of mites (mobile and eggs) were counted from 5 leaves/tree, and winter eggs from 5 twigs/tree.

\begin{tabular}{lcrrr}
\hline $\begin{array}{l}\text { Treatment and rate } \\
\text { (g a.i./100 I) }\end{array}$ & Date & \multicolumn{2}{c}{$\begin{array}{c}\text { Mites/leaf } \\
4.7 .\end{array}$} & $\begin{array}{c}\text { Winter- } \\
\text { eggs/10 cm }\end{array}$ \\
\cline { 3 - 4 } & & $\mathrm{M}$ & $\mathrm{E}$ \\
\hline A. Flubenzimine (150) & 30.5 & 8.7 & 4.1 & 336 \\
B. Chinomethionate (55) & $23.5 ., 9.6 ., 18.6$. & 12.1 & 5.0 & 478 \\
C. Chinomethionate (55) & 18.6. & 2.0 & 3.1 & 56 \\
\hline
\end{tabular}

Other treatments (all blocks): dimethoate (160 g a.i./100 l) 23.5. and 3.7., dithianon (225) 14.5., 23.5., 9.6., 23.6., 3.7. and 13.7. (for scab control).

Table 8. Results of the field experiment in 1988 (Agricultural Research Centre, Jokioinen). Fully randomized apple trees (6 per treatment) were sprayed according to apple scab spraying program, with a compression sprayer, on 23.5., 3.6. and 15.6., and with a knapsack mistsprayer on 21.6. and 27.6. Samples of 20 leaves/tree were checked and number of mites were counted or estimated (Eriophyidae).

\begin{tabular}{|c|c|c|c|c|}
\hline \multirow{3}{*}{$\begin{array}{l}\text { Treatment and rate } \\
(\mathrm{g} \text { a.i./100 l) }\end{array}$} & \multicolumn{4}{|c|}{ Number of mites/10 leaf (mobile and eggs) } \\
\hline & \multicolumn{2}{|c|}{ ERM } & \multirow{2}{*}{$\begin{array}{c}\text { Eriophyidae } \\
\text { M }\end{array}$} & \multirow{2}{*}{$\begin{array}{c}\text { Phytoseiidae } \\
\text { M }\end{array}$} \\
\hline & M & $\mathrm{E}$ & & \\
\hline A. Flubenzimine $(3 \times 25,2 \times 85)$ & 0.0 & 0.0 & $3.0 \mathrm{~A}$ & $0.03 \mathrm{~A}$ \\
\hline B. Clofentezine $(3 \times 25,2 \times 85)^{\prime}$ & 0.67 & 0.58 & $3.0 \mathrm{~A}$ & $3.5 \mathrm{~A}$ \\
\hline C. Hexythiazox $(3 \times 5,2 \times 17)^{\prime}$ & 0.17 & 0.33 & $83.0 \mathrm{~B}$ & $2.33 \mathrm{~A}$ \\
\hline D. Bitertanol $(3 \times 12.5,2 \times 42.5)^{2}$ & 1.25 & 0.75 & $95.0 \mathrm{~B}$ & $19.5 \mathrm{~B}$ \\
\hline E. No treatments & 1.17 & 0.75 & $67.0 \mathrm{~B}$ & $17.8 \mathrm{~B}$ \\
\hline
\end{tabular}

Means with different letters in columns denote significant differences $(\mathrm{P}=0.05)$ according to Duncan's multiple range test on log-transformed data. Columns without letters indicate a nonsignificant F-test.

1 New products, not analysed in this article (cf. TUOOINEN 1990).

2 Fungicide used against the apple scab. 


\section{DISCUSSION}

The growth of ERM populations strongly depends on temperature. In Finland, ERM has usually 3 , sometimes 4 yearly generations (Listo et al. 1939). During these experiments, the total effective temperature sums varied between 1030 dd in 1987 to 1520 dd in 1983. During the tests, manyfold differences in reproduction capacity of ERM due to temperature variations between years could be expected. The results of the experiments from various years are not directly comparable - on the other hand, one or two years' experiments may lead to erroneous conclusions as to the effect of acaricides on ERM.

Because flubenzimine is most effective against immature stages of ERM (ZOEBELEIN et al. 1980, KOLBE 1981), the timing of sprays is thought to be important especially in early season sprays. In an ideal situation, all winter eggs should have been hatched, but only larval or nymphal stages should be present at the moment when spraying takes place. In practice, the hatching of winter eggs lasts, in Finnish conditions, $2-3$ weeks depending on the temperature and the position of eggs on branches (Listo 1939). According to LeEs (1953) the threshold temperature for the embryonic postdiapause development of ERM winter egg is $+7{ }^{\circ} \mathrm{C}$. In laboratory experiments (not published), $50 \%$ of ERM winter eggs hatched when 200 dd above $+5{ }^{\circ} \mathrm{C}$ was reached. For practical purposes, the commonly used plant growth threshold $+5{ }^{\circ} \mathrm{C}$ can be referred to and may approach the correct value in Finland (cf. LisTo et al. 1939).

In field tests, temperature sums, recorded in the nearest meteorological stations, varied from 130 to $377 \mathrm{dd}$ in early season sprays. In most tests, winter eggs had begun to hatch but no summer eggs had been laid before the spray (exception: Pälkäne 1984, 377 dd, summer eggs were present in abundance). Good results were obtained with flubenzimine in all cases, except in Bromarv 1986 (180 dd). This orchard is situated on a cape surrounded by the sea - in spring the prevailing temperature is much colder than the inland temperature, where the temperatures were recorded. In this case, mites were not counted before spraying, but at least part of the winter eggs had already hatched.

The later sprays in June and July usually resulted in low numbers of mobile ERM. The results show that flubenzimine has a long lasting residual effect so that high numbers of summer eggs present on leaves during spraying or laid later by surviving adults do not lead to a high number of mobile ERM later in the season.

As a summary of all experiments, it is presented that one spray with flubenzimine (150250 g. a.i./100 I water, 300 1/ha) can keep ERM under the economic threshold level if sprayed when the sum of the effective temperature above $+5{ }^{\circ} \mathrm{C}$ reaches $200 \mathrm{dd}$ in spring. If temperature recordings are made within the orchard, which is recommended, the sum of $200-250$ dd will be accurate enough for timing the spray because of the climatically more favourable situation in the orchards. However, one spring application is not enough to diminish winter egg numbers the next autumn if the weather is suitable for egg laying. High numbers of overwintering ERM do not always lead to high numbers of mites in the summer rainy weather in the spring may considerably diminish ERM numbers (PUTMAN 1970). Besides, ERM winter mortality in Finland may often be quite high, $30-60 \%$ (Listo et al. 1939).

One spray with flubenzimine ( $150 \mathrm{~g}$ a.i./100 I water, $0.45 \mathrm{~kg} / \mathrm{ha}$ ) greatly reduced the number of predatory phytoseiid mites. This reduction cannot be explained by a reduction of prey, because the dominating phytoseiid species concerned Euseius finlandicus (Oud.), is known to also use other food sources than phytophagous mites, e.g. pollen, and has been 
found to be quite common on apple leaves also without phytophagous mites as prey (KROPCZYNSKA and TUOVINEN 1988). Another common species was Phytoseius macropilis (Banks). The same effect was obtained also by sprays with lower concentrations of flubenzimine (25$85 \mathrm{~g}$ a.i./100 I water) when sprayed 5 times per season. Vigl et al. (1985) also noted the harmful effect of flubenzimine to predatory mites. However, Comal (1985) sprayed flubenzimine in an even lower concentration (10 g a.i./100 1 water) and concluded that 6 sprays during the season did not affect coccinellids or a phytoseiid mite Typhlodromus spp.

Flubenzimine had no clear harmful effect on predatory insects in orchards. BONESs (1983) stated that anthocorid bugs were not badly damaged by flubenzimine in either larval or adult stages. This was found also in the present study. If no insecticidal sprays are performed, anthocorid bugs belong to the most important insect enemies of ERM in Finland (Listo et al. 1939). However, flubenzimine diminished spider numbers, which occur quite commonly in apple trees not treated with harmful insecticides.

Because of its harmful effects on predatory mites, at least Euseius finlandicus and Phytoseius macropilis, flubenzimine cannot be recommended for regular use in integrated control programs in apple orchards. However, because of the lesser effects on predatory insects e.g. anthocorid bugs, the use of flubenzimine may be reasonable also in IPM orchards in situations where quick reduction of ERM is necessary and phytoseiids are scarce.

None of the reference products was as effective as flubenzimine. The effect of chinomethionate was usually satisfactory and chinomethionate controlled even high populations of ERM, at least when applied twice. However, on many occasions, growers have reported an unsufficient effect by this acaricide. Dicofol was tested in only one experiment. The effect of a single spray was satisfactory, although not as good as that of flubenzimine. The effect of fenbutatinoxide was comparable to that of chinomethionate and dicofol. This acaricide is not approved for ERM control in Finland.

Oxydemetonmethyl had a good knock-down effect on ERM when sprayed after winter egg hatching. However, later in the season, an outbreak of ERM may occur, and a spray with an acaricide is needed. Because of the risk of residues, oxydemetonmethyl is not recommended for use in June or later. Although deltamethrin had an immediate effect on ERM, later in the season it caused an outbreak of ERM. This effect has been observed in many studies (e.g. MAnTINGER and Dipoli 1982, ARIAS and NiETO 1983). Because of these findings the use of deltamethrin and other pyrethroid insecticides are not recommended for summer sprays in apple orchards.

\section{REFERENCES}

Arias, A. \& Nieto, J. 1983. Eficacia de dos piretroides sobre Zeuzera pyrina L. y Laspeyresia pomonella L. y efecto secundario frente a Panonychus ulmi Koch. Anales del Inst. Nac. Invest. Agr. Agric. 24: 251-266.

Boness, M. 1983. Peropal, Alsystin und Cropotex: Untersuchungen über ihre Wirkung auf Nutzarthropoden. Pfl.schutz-Nachr. Bayer 36: 38-53.

Сомал, M. 1985. Grado di controllo del ragno rosso esercitato da nuovi prodotti acaricidi. Informatore Agrario 41: $65-68$.
Hassan, S. A., Albert, R., Bigler, F., Blaisinger, P., Bogen. SChÜtz, H., Boller, E., Brun, J., Chiverton, P., Edwards, P., Englert, W. D., Huang, P., Inglesfield, C., Naton, E., Oomen, P. A., Overmeer, W. P. J., Rieckmann, W., SAmsoe-Petersen, L., Stälibli, A., Tuset, J. J., Van. WETSWINKEL, G. \& VIGGIANI, G. 1987. Results of the third joint pesticide testing programme by the IOBC/WPRSworking Group sesticides and Beneficial Organisms*. J. Appl. Entomol. 103: 92-107.

KarG, W., Gottwald, R. \& Freier, B. 1987. Die Selektivităt 
von Pflanzenschutzmitteln und ihre Bedeutung Nachr.bl. Pfl.schutzd. DDR 41: 218-223.

KOLBE, W. 1981. Untersuchungen zur Bekämpfung der Obstbaumspinnmilbe (Panonychus ulmi) mit den Entwicklungshemmern Cropotex und Nikkomycin. Pfl. schutz-Nachr. Bayer 34: 264-301.

KROPCAYNSKA, D. \& TUOVINEN, T. 1988. Occurrence of phytoseiid mites (Acari: Phytoseiidae) on apple-trees in Finland. Ann. Agric. Fenn. 27: 305-314.

LeEs, A. D. 1953. Environmental factors controlling the evocation and termination of diapause in the fruit tree red spider mite Metatetranychus ulmi Koch (Acarina: Tetranychidae). Ann. Appl. Biol. 40: 449-486.

Listo, J., Listo, E.-M. \& Kanervo, V. 1939. Tutkimuksia hedelmäpuupunkista (Paratetranychus pilosus C. \& F.). (Ref: Studies of the fruit tree red mite (Paratetranychus pilosus C. \& F.). Valt. Maatal.koetoim. Julk. 99: 1-143.

Mantinger, H., Dipoli, P. 1982. Einfluss von syntetischen Pyrethroiden auf die Entwicklung von Spinnmilben Spritzversuch 1981. Obstbau Weinbau 19: 135-137.

Putman, W. L. 1970. Effects of water and high humidity on the European red mite, Panonychus ulmi (Acarina: Tetranychidae). Can. Entomol. 102: 955-961.

Steel, R. G. D. \& Torrie, J. H. 1980. Principles and procedures of Statistics. 2nd ed. McGraw-Hill, New York. $633 \mathrm{p}$.

SwırT, F. C. 1968. Population densities of the European red mite and the predaceous mite Typhlodromus (A.) fallacis on apple foliage following treatment with various insecticides. J. Econ. Entomol. 61: 1489-1491.

TUOVINEN, T. 1990. Chemical control of European red spider mite Panonychus ulmi (Koch.) II. Evaluation of clofentezine and hexythiazox. Ann. Agric. Fenn. (In print)

Vigl, J., Boscheri, S., Mantinger, H. 1985. Einfluss verschiedener Insektizide und Akarizide auf Raubmilben. Obstbau Weinbau 22: 108-112.

Zoebelein, G., Dörntlein, D., Hammann, I. \& Scholl, W. 1979. BAY SLJ 0312, ein Spinnmilben-Entwicklungshemmer aus einer neuen Wirkstoffklasse. Mitt. Biol. Bundesanst. Land-Forstwirtsch., Berlin-Dahlem, Heft 191: $283-284$.

-, Dörntlein, D. \& Hammann, I. 1980. Labor- und Freilandergebnisse mit Cropotex, einem Akarizid aus einer neuen Wirkstoffgruppe. Pfl.schutz-Nachr. Bayer 33 $169-184$.

\section{Manuscript receıved March 1989}

Tuomo Tuovinen

Agricultural Research Centre

Institute of Plant Protection

SF-31600 Jokioinen, Finland

\section{SELOSTUS}

\section{Hedelmäpuupunkin kemiallinen torjunta. I. Flubentsimiini.}

\section{TUOMO TUOVINEN}

Maatalouden tutkimuskeskus

Hedelmäpuupunkin torjunta tuottaa käytännön omenaviljelyksillä usein enemmän ongelmia kuin muiden tuhoeläinten torjunta. Biologisten tai muuten punkkien luontaisille vihollisille haitattomien menetelmien soveltaminen hyönteisten torjunnassa helpottaisi hedelmäpuupunkin luontaista torjuntaa. Ennen kuin tällaiset menetelmät ovat käytettävissä, on punkkien torjunta akarisideilla tarpeen.

Tällä hetkellä Suomessa on käytettävissä vain kaksi akarisidia: dikofoli ja kinometionaatti. Lisäksi oksidemetonimetyyli tehoaa myös punkkeihin. Akarisidien teho käytännössä on osoittautunut vaihtelevaksi, mikä saattaa osittain johtua mahdollisesta resistenssistä runsaasti käytettyjä valmisteita vastaan. Uusia tehokkaita ja luontaisille vihollisille mahdollisimman haitattomia akarisideja tarvitaan.

Flubentsimiini vaikuttaa kehrääjäpunkkien muodonvaihdokseen estämällä kitiinisynteesiä. Valmiste tehoaa punkin nuoruusasteisiin, mutta ei tapa aikuisia punkkeja. Suoritetuissa torjuntakokeissa valmiste osoittautui tehokkaaksi ja yksi ruiskutuskerta $(0.45-0.75 \mathrm{~kg}$ tehoainetta/ha, sumuruis- ku) ajoitettuna punkkien talvimunien kuoriutumisen loppuvaiheeseen, riitti pitämään punkkien määrän torjunnan kynnysarvojen alapuolella. Tehoisana lämpösummana (yli $+5^{\circ} \mathrm{C}$ ) mitaten sopiva käsittelyajankohta on kun $200-250$ astetta on saavutettu. Punkkien lisääntymiselle edullisissa oloissa, kuivan ja lämpimän sään vallitessa, toinen ruiskutus voi olla tarpeen heinäkuussa. Tällöin talvehtimaan jäävä punkkikanta on pieni ja ruiskutuksen vaikutus tuntuu vielä seuraavanakin vuonna. Maatalouden tutkimuskeskuksen tuhoeläinosasto on antanut Maatilahallitukselle myönteisen lausunnon flubentsimiinin käyttökelpoisuudesta ja tehokkuudesta vuonna 1984 .

Jatkotutkimuksissa todettiin flubentsimiinin tehoavan hyvin myös äkämäpunkkeihin, omenalla kellastajapunkkiin. Hedelmäpuupunkin luontaisiin vihollisiin, petopunkkeihin, valmiste vaikutti haitallisesti. Sen sijaan petoluteiden esiintymiseen valmiste vaikutti vain vähän. Flubentsimiinia voidaan käyttää myös integroitua torjuntaa soveltavissa tarhoissa silloin, kun petopunkkeja ei luontaisesti esiinny. 


\title{
CHEMICAL CONTROL OF EUROPEAN RED SPIDER MITE PANONYCHUS ULMI $(\mathrm{KOCH})$
}

\section{EVALUATION OF CLOFENTEZINE AND HEXYTHIAZOX}

\author{
TUOMO TUOVINEN
}

\begin{abstract}
TUOVInen, T. 1990. Chemical control of European red spider mite Panonychus ulmi (Koch). II. Evaluation of clofentezine and hexythiazox. Ann. Agric. Fenn. 29: 195-204. (Agric. Res. Centre, Dept. Plant Protect., SF-31600 Jokioinen, Finland.)

In laboratory tests, 250 and 500 ppm clofentezine sprayed on winter eggs of $P$. ulmi at $0-63$ day-degrees (dd) above $+7^{\circ} \mathrm{C}$, had a $68-92 \%$ effect. If sprayed just before the beginning of egg hatching ( 128 dd above $7^{\circ} \mathrm{C}$ ), the effect was only $35 \%$. In field tests, a good effect was obtained when clofentezine was sprayed before the beginning of embryonic development of winter eggs.

In laboratory tests, 50 and 100 ppm hexythiazox diminished hatching of undeveloped winter eggs (92 and $99 \%$ effect), but the effect was poor when sprayed after some development of the eggs had occurred $\left(77 \mathrm{dd}\right.$ above $\left.7^{\circ} \mathrm{C}\right)$. In field tests, hexythiazox had a good effect when sprayed in spring during the winter egg hatching period or in July.

When sprayed five times on trees with low density populations of $P$. ulmi, in coordination with the apple scab spraying schedule, clofentezine and hexythiazox significantly diminished the numbers of phytoseiid mites, but did not totally eliminate them. Single summer treatments with both acaricides were relatively harmless on phytoseiid mites Euseius finlandicus and Phytoseius macropilis. Repeated summer sprays with clofentezine reduced numbers of Aculus sclechtendali, but hexythiazox did not have any effect on eriophyiid mites.
\end{abstract}

Index words: chemical control, acaricides, clofentezine, hexythiazox, European red spider mite, Panonychus ulmi, Eriophyidae, Phytoseidae, Euseius finlandicus, Phytoseius macropilis.

\section{INTRODUCTION}

The results of the control experiments on the European red spider mite (ERM), Panonychus ulmi (Koch) (Acari: Tetranychidae), using flubenzimine compared to the conventional acaricides chinomethionate and dicofol as well as oxydemetonmethyl, have been published earlier (TUOVINEN 1989). Of the other available acaricides, ovicidal oil preparates have been widely used against ERM. Most of the ovicidal acaricides have been tar oil or various petroleum oil formulations. Sprays on winter eggs, before onset of the vegetation period, result in satisfactory control provided the coverage of the spray is complete and the egg hatching period short (van de VRIE 1985). In Finland, the hatching of winter eggs lasts several weeks (Listo et al. 1939) and this probably is the reason for the often poor effect of mineral oil 
preparates. The use of tar oils which have a good effect on ERM winter eggs is now prohibited in Finland because of the harmful compounds in these oils.

Recently, two new ovo-larvicidal compounds completely different in chemical structure as well as in mode of action compared to earlier acaricides have been introduced: clofentezine, effective primarily against eggs (BRYAN et al. 1981, NEAL et al. 1986) and hex- ythiazox, effective against the eggs and larvae of tetranychid mites (Welty et al. 1988). These two compounds have been tested in laboratory and field experiments in order to evaluate their effectiveness against ERM and their impact on other mite groups in apple trees. In this study, the results of the above tests are reported and the use of clofentezine and hexythiazox compared to other acaricides is discussed.

\section{MATERIAL AND METHODS}

Clofentezine was used as $50 \%$ WP formulation Apollo, produced by Schering AG, and hexythiazox as $10 \%$ WP formulation Nissorun 10 WP, produced by Nippon Soda Co.

As reference products, a mineral oil formulation (Ovipron, BP), chinomethionate (25\% WP formulation Morestan, Bayer AG), flubenzimine (50\% WP formulation Cropotex, Bayer AG) and oxydemetonmethyl (26.5\% EC formulation Metasystox, Bayer AG) were used. In some of the field experiments, insecticides and fungicides were applied following normal spraying schedules. These sprays were carried out using the recommended concentrations and doses.

\section{Laboratory experiments}

Twigs containing ERM winter eggs were sampled from orchards during winter and were stored in $0-+3{ }^{\circ} \mathrm{C}$ before tests. For each test, twigs from the same orchard were used. 5-10 pieces $1-3 \mathrm{~cm}$ in length, halved twig bits containing 25-50 eggs each were put into petri dishes on filter paper and sprayed with $2 \mathrm{ml}$ of water diluted preparate in a Potter tower. Control dishes were sprayed with pure water. After spraying, the twig bits were put on petri dishes and each bit circled by insect glue. The dishes were preserved in a growing chamber at $+20 /+15{ }^{\circ} \mathrm{C}$ temperature, $75 \pm 10 \% \mathrm{Rh}$ and $13 / 11 \mathrm{~h}$ photoperiod (L/D). The dishes were uncovered. Each treatment was replicated four times and control dishes were included. The twig bits were checked two and four weeks after the treatments and the hatched larvae stuck in the insect glue were counted.

Clofentezine at 0.025 and $0.05 \%$ a.i. dilutions was tested using eggs at various developmental stages. Eggs were obtained by preserving twigs in $0{ }^{\circ} \mathrm{C},+5{ }^{\circ} \mathrm{C},+10^{\circ} \mathrm{C}$ and $+15^{\circ} \mathrm{C}$ for $0-21$ days. Hexythiazox was tested on undeveloped and partly developed eggs using 0.005 and $0.01 \%$ a.i. dilutions.

During laboratory experiments in growing chambers, the temperature sums were recorded using a growing degree day accumulator (TA51-P, Omnidata Int. Inc.). As a threshold temperature for winter egg development, +5 and $+7{ }^{\circ} \mathrm{C}$ was used (LeEs 1953).

\section{Field experiments}

In a commercial orchard, Paimio 1986-88, clofentezine was compared with chinomethionate and flubenzimine in two 0.5 ha blocks. In Piikkiö, 1988, hexythiazox was compared with chinomethionate in a demonstrative test. In both orchards, insecticides against moths and 
fungicides against the apple scab Venturia inaequalis (Cooke) Winter were also used.

In an experimental orchard, Jokioinen 1988, hexythiazox and clofentezine together with flubenzimine, were tested using fully randomized design and six single tree replicates. Preparates were sprayed according to the apple scab spraying schedule using lower concentrations in order to check the possible effect of these acaricides on apple scab. As a reference product bitertanol (Baykor, Bayer AG) was sprayed against the apple scab.

In an experimental orchard, Pälkäne 1988, summer applications of hexythiazox were studied using randomized block design and three single tree replicates. In 1989, the effect of early sprays of clofentezine, hexythiazox and a mineral oil preparate was studied.

In Paimio and Piikkiö the effect of sprays was checked 1-4 times during summer by sampling 5 leaves of equal size and position from $10-20$ randomly selected trees, and in the au- tumn, by sampling five $20 \mathrm{~cm}$ twig pieces from $10-20$ trees. In Jokioinen, 20 leaves from each tree were sampled in July, and in Pälkäne, 10 leaf-rosettes in spring and 10 leaves during summer from each tree were sampled. Numbers of living mobile mites and ERM eggs were counted under a stereomicroscope. All relevant mite groups, including Tetranychidae, Tydeidae, Phytoseiidae and Eriophyidae, were observed. In some cases, numbers of eriophyids were estimated using a scale from 0 (= no mites) to 3 (= over 100 mites/leaf).

Meteorological data were obtained from the nearcst meteorological station (Piikkiö and Pälkäne). Cumulative temperature sums over $+5^{\circ} \mathrm{C}$ (day-degrees) were calculated for timing of the sprays. Data from laboratory tests were analysed using the analysis of variance (Tukey's test) and from the field experiments using either t-test or analysis of variance (Duncan's multiple range test) on $\log (\mathrm{x}+1)$-transformed data (STEEL and TORRIE 1980).

\section{RESULTS}

\section{Laboratory experiments}

The temperature sums needed for the beginning of ERM winter egg hatching were 140 day-

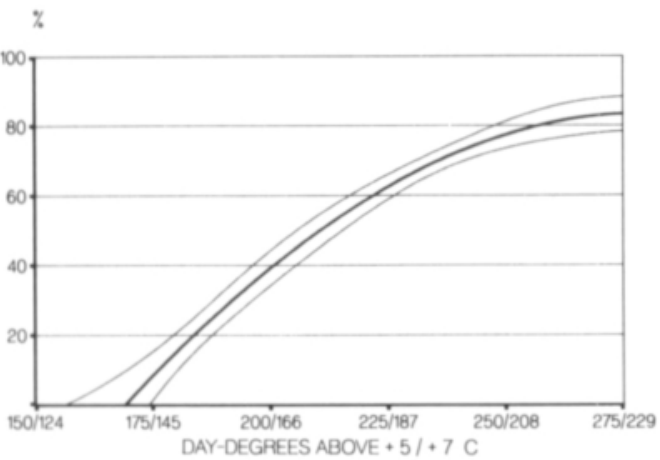

Fig. 1. Hatching of ERM winter eggs in a growing chamber in $+20 / 15^{\circ} \mathrm{C}, 13 / 11 \mathrm{~h}$ photoperiod (L/D) and $75 \pm 10 \%$ $\mathrm{Rh}$. Day-degrees recorded from the beginning of the test. Regression curve calculated from 19 replicates, $95 \%$ confidence intervals are included. degrees for $+7{ }^{\circ} \mathrm{C}$ and 170 dd for $+5^{\circ} \mathrm{C}$ threshold temperatures (Fig. 1). Half of the eggs were hatched when 170 and 200 dd above +7 and $+5^{\circ} \mathrm{C}$ were reached, respectively.

Table 1. Effect of clofentezine on ERM winter eggs at different stages of egg development. Treatments in Potter tower, $2 \mathrm{ml}$ of dilution/replicate (see text).

\begin{tabular}{|c|c|c|c|c|}
\hline \multicolumn{2}{|c|}{ Preserving } & \multirow{2}{*}{$\begin{array}{c}\text { dd } \\
\left(7^{\circ} \mathrm{C}\right)\end{array}$} & \multicolumn{2}{|c|}{ Effect \% (Abbott) } \\
\hline temp. $\left({ }^{\circ} \mathrm{C}\right)$ & time (d) & & $250 \mathrm{ppm}$ & 500 ppm \\
\hline 0 & 7 & 0 & $87.3^{b}$ & $91.5^{b}$ \\
\hline $\begin{array}{l}5 \\
5\end{array}$ & $\begin{array}{l}14 \\
28\end{array}$ & $\begin{array}{l}0 \\
0\end{array}$ & $\begin{array}{l}92.2^{\mathrm{b}} \\
68.4^{\mathrm{b}}\end{array}$ & $\begin{array}{l}90.7^{b} \\
81.0^{b}\end{array}$ \\
\hline $\begin{array}{l}10 \\
10 \\
10\end{array}$ & $\begin{array}{r}7 \\
14 \\
21\end{array}$ & $\begin{array}{l}21 \\
42 \\
63\end{array}$ & $\begin{array}{l}77.9^{\mathrm{b}} \\
83.4^{\mathrm{b}} \\
77.2^{\mathrm{b}}\end{array}$ & $\begin{array}{l}82.0^{\mathrm{b}} \\
92.5^{\mathrm{b}} \\
79.8^{\mathrm{b}}\end{array}$ \\
\hline 15 & 16 & 128 & $37.3^{2}$ & $35.1^{2}$ \\
\hline
\end{tabular}

Means with different letters in columns denote significant differences $(\mathrm{P}<0.05)$ according to Tukey's test. 
Clofentezine affected undeveloped ERM winter eggs well (Table 1). As embryonic development progressed the effect of clofentezine on egg hatching diminished when sprayed $1-2$ days before hatching. The concentration of 250 ppm was only slightly less effective than the double one.

Hexythiazox at 50 and 100 ppm concentration killed the undeveloped winter eggs almost totally but, like clofentezine, the effect on the more developed eggs was poor (Table 2).
Table 2. Effect (Abbott) of hexythiazox and clofentezine on ERM winter eggs. Exp. 1. was carried out on undeveloped eggs, Exp. 2. On winter eggs after preserving in $+20 / 15^{\circ} \mathrm{C}$ for 7 days $\left(=77\right.$ dd above $\left.7{ }^{\circ} \mathrm{C}\right)$. Treatments as in Table 1.

\begin{tabular}{lrrrr}
\hline Treatment (\% a.i.) & \multicolumn{4}{c}{ Effect \% (hatch. \%) } \\
\cline { 2 - 5 } & \multicolumn{2}{c}{ Exp. 1. } & \multicolumn{2}{c}{ Exp. 2. } \\
\hline Hexythiazox (0.005) & 99.3 & $\left(0.6^{\mathrm{a}}\right)$ & 24.4 & $\left(70.5^{\mathrm{b}}\right)$ \\
Hexythiazox (0.01) & 99.4 & $\left(0.5^{\mathrm{a}}\right)$ & 48.9 & $\left(47.6^{\mathrm{a}}\right)$ \\
Clofentezine (0.025) & 92.6 & $\left(6.2^{\mathrm{b}}\right)$ & 34.9 & $\left(60.7^{\mathrm{b}}\right)$ \\
Untreated & & $\left(84.1^{\mathrm{c}}\right)$ & & $\left(93.3^{\mathrm{c}}\right)$ \\
\hline
\end{tabular}

Means with different letters in columns indicate significant differences $(\mathrm{P}<0.05)$ in hatching-\% according to Tukey's test.

\section{Field experiments}

In 1986, Paimio, clofentezine was sprayed on winter eggs, a few of which had already hatched $(9.5 .$, sprayed when 83 day-degrees above $+5{ }^{\circ} \mathrm{C}$ was reached). The initial ERM winter egg density was high, $199 \mathrm{eggs} / 10 \mathrm{~cm}$ branch, leading to a high population level on the control block. At first, in June, the effect of clofentezine was satisfactory compared to the control block, but in July and August, an outbreak of ERM occurred (Table 3). A spray

Table 3. Results of the field experiment in Paimio, 1986. Blocks of about 0.5 ha were sprayed with a mist sprayer, $300 \mathrm{l} / \mathrm{ha}$. Numbers of mobile mites and eggs were counted from 5 leaves/tree, and numbers of winter eggs from 5 twigs/tree from 10 trees/treatment. Before the treatment in spring the number of winter eggs was $199 / 10 \mathrm{~cm}$ twig.

\begin{tabular}{|c|c|c|c|c|c|c|c|c|}
\hline \multirow{3}{*}{$\begin{array}{l}\text { Treatment and rate } \\
(\mathrm{g} \text { a.i. } / 100 \mathrm{l})\end{array}$} & \multirow[t]{3}{*}{ Date } & \multicolumn{6}{|c|}{ No. of ERM/leaf (mobile and eggs) } & \multirow{3}{*}{$\begin{array}{c}\text { ERM } \\
\text { winter- } \\
\text { eggs }\end{array}$} \\
\hline & & \multirow{2}{*}{$\begin{array}{l}29.5 . \\
\text { mob }\end{array}$} & \multirow{2}{*}{$\begin{array}{l}19.6 \\
\text { mob }\end{array}$} & \multicolumn{2}{|c|}{23.7} & \multicolumn{2}{|c|}{16.9} & \\
\hline & & & & mob & eggs & mob & eggs & \\
\hline Clofentezine (100) & 9.5 & 8.3 & 1.1 & 29.4 & 43.2 & 75.1 & 34.8 & 219 \\
\hline Chinomethionate (62.5) & 4.6. & 104.5 & 1.9 & 70.5 & 75.8 & 68.3 & 46.0 & 267 \\
\hline T-test & & $\cdots$ & NS & $\cdots$ & $\cdots$ & NS & $\cdot$ & NS \\
\hline
\end{tabular}

Other treatments in the area: fenitrothion $(375 \mathrm{~g}$ a.i./100 l) 20.5. (only clofentezine) and 19.6., dimethoate (133) 7.7. dithianon (225) 14.5., 23.5., 4.6., 9.6., 19.6., 13.7. and triforine (123.5) 7.7. (for scab control). ${ }^{*} \mathrm{P}<0.05 ; \cdots \mathrm{P}<0.001$

Table 4. Results of the field experiment in Paimio, 1987. Blocks of about 0.5 ha were sprayed with a mist sprayer, $300 \mathrm{l} / \mathrm{ha}$. Numbers of ERM were counted from 5 leaves/tree, and numbers of winter eggs from 5 twigs/tree from 10 trees/treatment. Before the sprays in spring the number of winter eggs was $243 / 10 \mathrm{~cm}$ twig.

\begin{tabular}{|c|c|c|c|c|c|c|c|c|}
\hline \multirow{3}{*}{$\begin{array}{l}\text { Treatment and rate } \\
(\mathrm{g} \text { a.i. } / 100 \mathrm{l})\end{array}$} & \multirow[t]{3}{*}{ Date } & \multicolumn{6}{|c|}{ No. of ERM/leaf (mobile and eggs) } & \multirow{3}{*}{$\begin{array}{c}\text { ERM } \\
\text { winter- } \\
\text { eggs }\end{array}$} \\
\hline & & \multirow{2}{*}{$\begin{array}{l}22.6 . \\
\text { mob }\end{array}$} & \multicolumn{2}{|c|}{16.7.} & \multicolumn{2}{|c|}{30.7} & \multirow[t]{2}{*}{$\overline{\text { Erioph. }}$} & \\
\hline & & & mob & eggs & mob & eggs & & \\
\hline Clofentezine $(100)$ & 29.4 & 0.04 & 0.22 & 0.32 & 0.31 & 1.3 & $>100$ & -1 \\
\hline Flubenzimine (250) & 10.6 & - & 0.12 & 0.33 & 1.6 & 3.9 & 0 & 17.5 \\
\hline T-test & & & NS & NS & $\cdot$ & NS & - & \\
\hline
\end{tabular}

1 - sign indicates missing data.

Other treatments in the whole area: dimethoate (133 g a.i./100 l) 3.6. and 22.7., dithianon (250) 18.5., 3.6., 10.6., 14.6., 23.6., 29.6. and 9.7. (for scab control). ${ }^{*} \mathrm{P}<0.05$ 
Table 5. Results of the field experiment in Paimio, 1988. Blocks of about 0.5 ha were sprayed with a tractor mist sprayer, 400 1/ha. Numbers of ERM were counted from 100 leaves/treatment and winter eggs from 20 twigs/treatment.

\begin{tabular}{|c|c|c|c|c|c|c|c|c|}
\hline \multirow{3}{*}{$\begin{array}{l}\text { Treatment and rate } \\
\text { (g a.i./100 l) }\end{array}$} & \multirow[t]{3}{*}{ Date } & \multicolumn{7}{|c|}{ No. of ERM/leaf (mobile and eggs) } \\
\hline & & \multicolumn{2}{|c|}{15.6.} & \multicolumn{2}{|c|}{30.6 . } & \multirow[t]{2}{*}{ Erioph. } & \multicolumn{2}{|c|}{10.8} \\
\hline & & mob & eggs & mob & eggs & & mob & eggs \\
\hline $\begin{array}{l}\text { Hexythiazox }(15.0)+ \\
\text { chinomethionate }(62.5)\end{array}$ & $\begin{array}{l}\text { 19.5. }+ \\
\text { 4.7., } 14.7 .\end{array}$ & 0.04 & 0.4 & 1.0 & 2.2 & 71.1 & 0.0 & 0.0 \\
\hline Chinomethionate (62.5) & $\begin{array}{c}20.5 ., 4.7 . \\
14.7 .\end{array}$ & 0.03 & 7.2 & 13.7 & 38.1 & 40.6 & 0.0 & 0.3 \\
\hline T-test & & NS & $\cdots$ & $\cdots$ & $\cdots$ & $\cdots$ & - & NS \\
\hline
\end{tabular}

Other treatments in whole area: dimethoate (133 g a.i./100 l) 20.-23.5., 4.7. and 14.7., dithianon (250) 23.5., 2.6., 9.6. and 21.6., bitertanol (100) 27.6. (for scab control). $\cdots \mathrm{P}<0.01, \cdots \mathrm{P}<0.001$

Table 6. Results of the field experiment in Piikkiö, 1988. Blocks of $0.25-0.5$ ha were sprayed with a mist sprayer, $400 \mathrm{l} / \mathrm{ha}$. Numbers of ERM were counted from 5 leaves/tree, and winter eggs from 10 twigs/treatment.

\begin{tabular}{|c|c|c|c|c|c|c|}
\hline \multirow{3}{*}{$\begin{array}{l}\text { Treatment and rate } \\
(\mathrm{g} \text { a.i. } / 100 \mathrm{l})\end{array}$} & \multirow[t]{3}{*}{ Date } & \multicolumn{4}{|c|}{ No. of ERM/leaf } & \multirow{3}{*}{$\begin{array}{c}\text { ERM } \\
\text { winter- } \\
\text { eggs }\end{array}$} \\
\hline & & \multicolumn{2}{|c|}{8.6.} & \multicolumn{2}{|c|}{10.8.} & \\
\hline & & mob & eggs & mob & eggs & \\
\hline Hexythiazox (12.5) & 24.5 . & 0.0 & 0.2 & 3.6 & 11.7 & 132 \\
\hline $\begin{array}{l}\text { Hexythiazox }(12.5)+ \\
\text { chinomethionate }(62.5)\end{array}$ & $\begin{array}{c}24.5 . \\
3.6 .\end{array}$ & 0.3 & 0.3 & 1.3 & 4.0 & 95 \\
\hline Chinomethionate (62.5) & $27.5 ., 3.6$ & 0.2 & 0.6 & 4.0 & 23.1 & -1 \\
\hline
\end{tabular}

1 not counted

Other treatments in whole area: fenitrothion (375 g a.i./100 l) 18.5., dimethoate (160) 30.6., bitertanol (125) 24.5., 3.6., 23.6., 30.6. (for scab control).

with chinomethionate before any summer eggs were laid (4.6., $225 \mathrm{dd})$ was also satisfactory, but later the numbers of ERM burgeoned. June and July were warmer than usual, favouring the outbreak of ERM. Only a few specimens of phytoseiid mites were found in this experiment and predatory insects were extremely scarce, too. Tydeids were not found and eriophyids were present only in low numbers.

In 1987, the effect of clofentezine was compared to that of flubenzimine in Paimio. Now, clofentezine was sprayed earlier (29.4., 0 dd) than in 1986 and winter eggs had not yet begun to develop. Both clofentezine and flubenzimine (10.6., $124 \mathrm{dd}$ ) had a good effect on ERM (Table 4). Clofentezine did not have any effect on the apple rust mite Aculus schlechtendali
(Nal.) (Acari: Eriophyidae), whereas no gall mites were found in the trees sprayed with flubenzimine. A few larvae of a dipterous predator Arthrocnodax mali Kieffer (Diptera: Cecidomyiidae) were found on leaves treated with clofentezine, but none on flubenzimine treated leaves. Exceptionally cold and rainy weather in summer 1987 (1030 dd during the whole season) suppressed ERM reproduction. However, in a neighbouring block, not included in the experiment, which was sprayed with chinomethionate (26.6.) mobile ERM numbers exceeded 10/leaf at the end of July.

In Paimio, 1988, the effect of one spray with hexythiazox was compared to chinometionate. A spring spray before the beginning of the egg hatching period (19.5., $89 \mathrm{dd})$, at first resulted 
in good control but because of the very warm weather, the number of ERM grew quite high in the chinometionate block (Table 5). The two late treatments with chinometionate prevented a mite outbreak in July. Repeated treatments with chinometionate had some effect on eriophyids. Phytoseiid mites were not found in this experiment.

In Piikkiö, 1988, sprays with hexythiazox (24.5., $115 \mathrm{dd}$ ) and chinomethionate (27.5., 138 dd and 3.6., 200 dd) resulted in satisfactory control of ERM (Table 6). Eriophyids, tydeids or phytoseiids did not occur in experimental blocks. Summer 1988 was very warm (1564 dd during the whole season) which led to quite a high overwintering population of ERM.

In 1988, Jokioinen, clofentezine, hexythiazox and flubenzimine were sprayed in lower concentrations according to the apple scab spraying schedule (Table 7). The initial density of ERM was low, and the effect of sprays could not be confirmed, although the acaricidal treat-

Table 7. Results of the field experiment in Jokioinen, 1988. 6 apple trees/treatment were sprayed according to the apple scab spraying program, with a knapsack compression sprayer, on 23.5., 3.6. and 15.6., and with a knapsack mist sprayer on 21.6. and 27.6. Samples of 20 leaves/tree were checked 18.7. and number of mites were counted or estimated (Eriophyidae).

\begin{tabular}{lcccc}
\hline $\begin{array}{l}\text { Treatment and rate } \\
(\mathrm{g} \text { a.i./100 1) }\end{array}$ & \multicolumn{4}{c}{ Number of mites/10 leaf } \\
\cline { 2 - 3 } & \multicolumn{2}{c}{ ERM } & Erioph. & Phytos. \\
\cline { 2 - 3 } & mob & eggs & & \\
\hline $\begin{array}{l}\text { Flubenzimine } \\
(3 \times 25,2 \times 85)\end{array}$ & 0.0 & 0.0 & $3.0^{\mathrm{a}}$ & $0.03^{\mathrm{a}}$ \\
$\begin{array}{l}\text { Clofentezene } \\
(3 \times 25,2 \times 85)\end{array}$ & 0.67 & 0.58 & $3.0^{\mathrm{a}}$ & $3.5^{\mathrm{a}}$ \\
$\begin{array}{l}\text { Hexythiazox } \\
(3 \times 5,2 \times 17)\end{array}$ & 0.17 & 0.33 & $83.0^{\mathrm{b}}$ & $2.33^{\mathrm{a}}$ \\
$\begin{array}{l}\text { Bitertanol } \\
(3 \times 12.5,2 \times 42.5)\end{array}$ & 1.25 & 0.75 & $95.0^{\mathrm{b}}$ & $19.5^{\mathrm{b}}$ \\
No treatments & 1.17 & 0.75 & $67.0^{\mathrm{b}}$ & $17.8^{\mathrm{b}}$ \\
\hline
\end{tabular}

1 Fungicide used against the apple scab.

Means with different letters in columns denote significant differences $(\mathrm{P}<0.05)$ according to Duncan's multiple range test on log-transformed data. Columns without letters indicate a nonsignificant F-test.

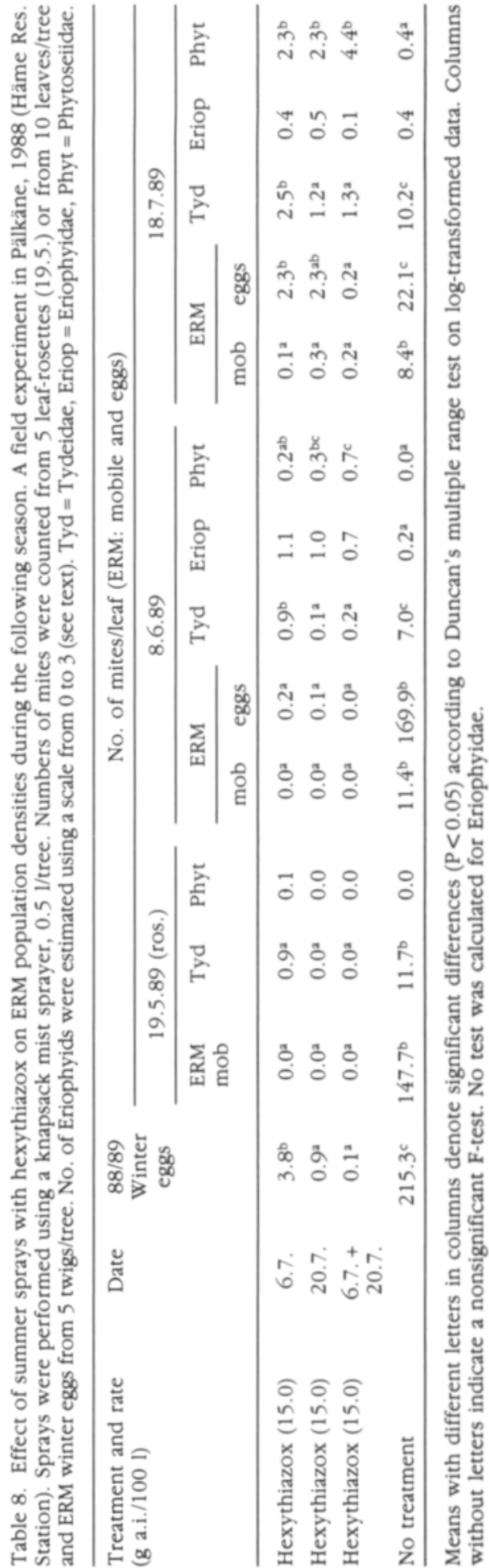




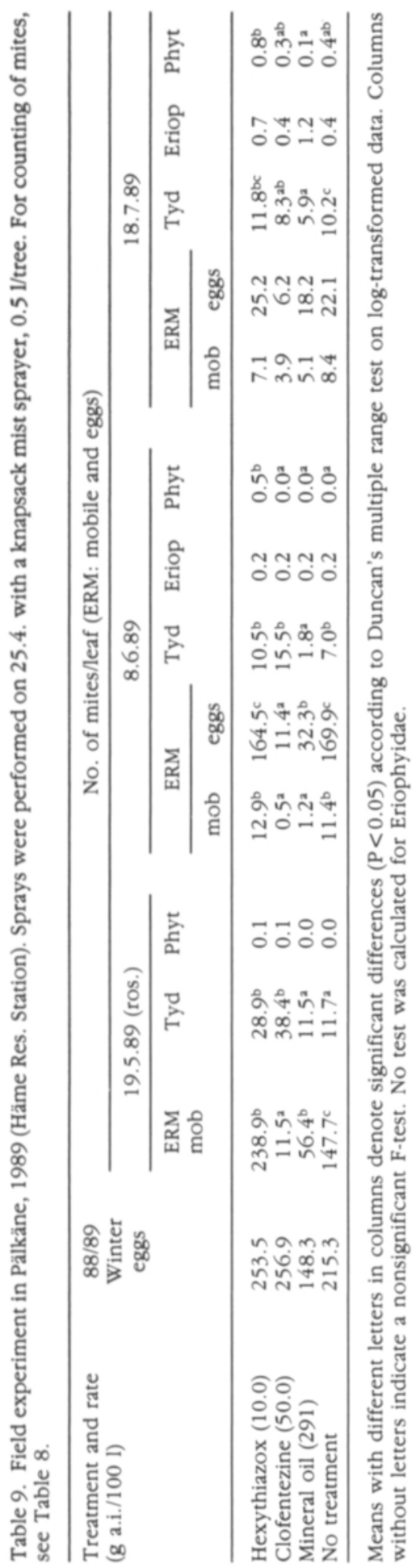

ments reduced numbers of ERM. Clofentezine had a good effect on the apple rust mite but it did not affect the other mites present on the leaves, the most frequent species belonging to Tydeidae. Hexythiazox had no effect on eriohyids. Both clofentezine and hexythiazox diminished the numbers of phytoseiid mites $\mathrm{Eu}$ seius finlandicus (Oud.) and Phytoseius macropilis (Banks) but not as dramatically as flubenzimine. Neither of the acaricides affected the apple scab. The fungicide bitertanol had no effect on mites.

In 1988, Pälkäne, one or two summer sprays with hexythiazox resulted in very low densities of overwintering ERM eggs (Table 8). One spray was as effective as two sprays with a twoweek interval and timing of the sprays had only a slight effect, the later treatment being slightly better. Because of the very warm summer, ERM density in untreated trees grew quite high. Mite population densities were checked during the next summer and on the treated trees ERM population stayed very low although the weather conditions were favourable for mites. The numbers of phytoseiids and eriophyids were not lower than in control trees, but tydeid mites were less numerous. No other pesticides were used in this part of the orchard during 1988 - 89, which made it possible for predatory bugs, especially Anthocoris nemorum (L.) (Heteroptera: Anthocoridae), to be present in high numbers and feed on mites. The effect of anthocorids was clearly seen in control trees, where ERM numbers diminished although phytoseiids were quite scarce.

In 1989, early spring treatments (25.4., 0 dd) with clofentezine or mineral oil on a high population of overwintering ERM eggs resulted in good control (Table 9). Hexythiazox did not have any effect on ERM. None of the treatments lowered the number of phytoseiid mites; mineral oil had an adverse effect on tydeids. 


\section{DISCUSSION}

Results of the laboratory tests suggested the use of clofentezine early in spring, before or in the beginning of the embryonic development of eggs. Field tests confirmed this finding. BAILLOD et al. (1986), using $0.04 \%$ a.i. clofentezine in laboratory tests on eggs 8 days before hatching, achieved better results at constant $+12^{\circ} \mathrm{C}$ temperature $\left(97 \%\right.$ effect) than at $+15^{\circ} \mathrm{C}$ $(74 \%)$ or at $+20^{\circ} \mathrm{C}(32 \%)$. These results also support a rather early use of clofentezine. However, BRYAN et al. (1981) recommend spray with clofentezine just before winter egg hatching, partly because of the residual effect of clofentezine on young larvae - nymphal and adult stages of ERM are not affected by clofentezine. The laboratory test method used herein did not reveal the residual effect on newly hatched larvae. With respect to the results of the field tests, the residual effect of clofentezine was clearly seen. Early sprays of clofentezine should be preferred when conditions are favourable, otherwise the spray at the beginning of egg hatching will result in good control, too. According to Rоск (1987), also a single summer application using $142-284 \mathrm{~g}$ a.i./ha led to good and long-lasting control of ERM.

The doses of clofentezine used in this study varied from 150 to $300 \mathrm{~g}$ a.i./ha. PEREGRINE et al. (1986) studied the influence of application volume in early spring sprays using a constant amount of $200 \mathrm{~g}$ a.i./ha. They concluded that clofentezine was effective on all tested volumes ranging from 100 to $2000 \mathrm{l} / \mathrm{ha}$, but higher volumes resulted in more uniform results. In Finland, growers usually spray $200-400$ 1/ha, which seems to be sufficient when spring sprays are concerned.

In laboratory tests, hexythiazox was effective on undeveloped ERM winter eggs both with 50 and $100 \mathrm{ppm}$ concentrations, but more developed eggs ( $77 \mathrm{dd}$ above $+7^{\circ} \mathrm{C}$ ) were affected much less. In laboratory tests carried out by WELTY et al. (1988) they found that the effect of 100 ppm hexythiazox on eggs sprayed less than 2 days before hatching was only $52 \%$, compared with $90-93 \%$ on less developed eggs. However, the residual effect of $100 \mathrm{ppm}$ hexythiazox on newly hatched larvae was 94-100\% (WeLTY et al. 1988).

In field tests, the effect of hexythiazox sprayed at the beginning of the egg hatching period was satisfactory, but an early spray before the beginning of egg development did not have any effect at all. The reason for this cannot be explained for certain, but e.g. weather conditions in the field after the treatment often reduce the effectiveness of pesticides compared to laboratory conditions. Rainfall may have influenced hexythiazox - in Pälkäne the 3rd and 4th days after the spray were rainy: 5.8 $\mathrm{mm}$ and $17.9 \mathrm{~mm}$ of rainfall, respectively. In conclusion, hexythiazox cannot be recommended for early spring sprays under Finnish conditions. The effect of clofentezine, sprayed at the same time, was very good, and also the mineral oil spray resulted in satisfactory control.

Hexythiazox (15 g a.i./100 1 water, 300 l/ha) proved to be very good against ERM when sprayed once or twice in July. Also Rock (1987) obtained a good effect with a single spray (71 $\mathrm{g}$ a.i./ha) in the beginning of June in North Carolina, USA. In the present study, during 1988-89, which was much warmer than normal, one spray in July was enough to maintain the population of ERM at quite a low level. However, this low level is certainly not only based on the effect of the acaricide, but also is a result of the activity of natural enemies. Phytoseiid mites were numerous in all the treated trees, and Anthocoris spp. bugs were also common. These tests demonstrated that omission of harmful pesticides allows natural enemies to maintain the population of ERM at a low level (c.f. KROPCZYNSKA and TUOVINEN 1988). 
Clofentezine and hexythiazox, when sprayed five times during the season in lower concentrations, clearly diminished the number of phytoseiid mites. However, quite high populations of phytoseiids remained on the leaves, showing that the preparates were not very toxic to predatory mites. HOY and OUYANG (1986) noted that clofentezine and hexythiazox were less toxic to the eggs of a predatory mite Metaseiulus occidentalis Nesbitt than to the eggs of the tetranychid mites Tetranychus pacificus McGregor and T. urticae Koch. KARG et al. (1987) graded clofentezine as a harmless acaricide for a wide range of natural enemies. In their summary article on the side effects of pesticides, BOLLer et al. (1989) presented that both acaricides are harmless to Typhlodromus pyri Scheuten. In this study, the most common phytoseiid species were Phytoseius macropilis and Paraseiulus soleiger. Repeated sprays of clofentezine and hexythiazox most likely affected, to some extent, the eggs and larvae but not the adult or nymphal stages and thus caused the reduction in phytoseiid numbers compared with control trees. Normally these acaricides are sprayed only once per season. The reference acaricide, flubenzimine, was harmful to all mite groups inhabiting apple trees (cf. TuOvINEN 1989).

Hexythiazox and clofentezine are thought to be a solution to the resistance problems which have arisen when the selective organotin acaricides cyhexatin and fenbutatinoxide have been employed without taking advantage of their selectivity (CROFT et al. 1987). In Finland, organotin acaricides have not been used against ERM, but the future use of both clofentezine and hexythiazox should be even more circumspect than that of the conventional acaricides and unnecessary treatments should be avoided. This is necessary to prevent the occurrence of possible resistance problems for as long as possible. To achieve this goal, the monitoring of both ERM and phytoseiid populations should be included as an integral part of the commercial apple growing technique.

\section{REFERENCES}

Baillod, M., Guignard, E. \& Antonin, P. 1986. Une nouvelle generation d'acaricides specifiques inhibiteurs de croissance. Revue Suisse Vitic. Arboric. Hortic. 18: 213-219.

Boller, E., Bigler, F., Bieri, M., HãNI, F. \& Stãubli, A. 1989. Nebenwirkungen von Pestiziden auf die Nützlingsfauna landwirtschaftlichen Kulturen. Schweiz. Landw. Forschung 28: 3-40.

Bryan, K.M.G., Geering, Q.A. \& ReId, J. 1981. NC21314, a novel compound for control of phytophagous mites. Proc. Brit. Crop Protect. Conf. Pests and Diseases 1981: $67-74$

Croft, B.A., Hoyt, C. \& Westigard, P.H. 1987. Spider mite management on pome fruits, revisited: organotin and acaricide resistance management. J. Econ. Entomol. 80: 304-311.

HoY, M.A. \& YU-Ling OUYiang. 1986. Selectivity of the acaricides clofentezine and hexythiazox to the predator Metaseiulus occidentalis (Acari: Phytoseiidae). J. Econ. Entomol. 79: 1377-1380.

KARG, W., GotTWALD, R. \& FreIER, B. 1987. Die Selektivität von Pflanzenschutzmitteln und ihre Bedeutung. Nachr.Bl. Pflanzenschutzd. DDR 41: 218-223.
KropCZYNSKA, D. \& TUOVINEn, T. 1988. Occurrence of phytoseiid mites (acari: Phytoseiidae) on apple-trees in Finland. Ann. Agric. Fenn. 27: 305-314.

LeEs, A.D. 1953. Environmental factors controlling the evocation and termination of diapause in the fruit tree red spider mite Metatetranychus ulmi Koch (Acarina: Tetranychidae). Ann. appl. Biol. 40: 449-486.

Listo, J., Listo, E.-M. \& KAnervo, V. 1939. Tutkimuksia hedelmäpuupunkista (Paratetranychus pilosus C. \& F.). (Ref. Studies of the fruit tree red mite (Paratetranychus pilosus C. \& F.)). Valt. Maatal.koetoim. Julk. 99: 1-143.

Peregrine, D.J., Doughton, N.E. \& Southcombe, E.S.E. 1986. The influence of application volume on the efficacy of clofentezine used early season for the control of Panonychus ulmi (Koch) on apples. Brit. Crop Prot. Conf., Pests and Diseases 307-314.

Rock, G.C. 1987. Summer evaluation of hexythiazox and clofentezine against three spider mite species in north Carolina apple orchards. J. Agric. Entomol. 4: 55-60.

Steel, R.G.D. \& Torrie, J.H. 1980. Principles and procedures of Statistics. 2nd ed. McGraw-Hill, New York. $633 \mathrm{p}$.

TUOVINEN, T. 1989. Chemical control of European red spi- 
der mite Panonychus ulmi (Koch.), I. Evaluation of flubenzimine. Ann. Agric. Fenn. 28: 317-332.

Welty, C., ReISSIG, W.H., DenNehy, T.J. \& WeIrES, R.W. 1988. Susceptibility to hexythiazox of eggs and larvae of European red spider mite (Acari: Tetranychidae). J. Econ. Entomol. 81: 586-592.

VRIE, M. van de 1985. Control of Tetranychidae on crops. Apple. In: Helle, W. \& Sabelis, M.W. (Eds.). Spider mites. Their biology, natural enemies and control. Vol. $1 \mathrm{~B}$ : 319-326. Elsevier, Amsterdam.
Manuscript received October 1989

Tuomo Tuovinen

Agricultural Research Centre

Institute of Plant Protection

SF-31600 Jokioinen

\section{SELOSTUS}

\section{Hedelmäpuupunkin kemiallinen torjunta}

\section{Clofentetsiini ja hexythiazox}

\section{TUOMO TUOVINEN}

Maatalouden tutkimuskeskus

Hedelmäpuupunkin torjuntaan soveltuvista torjunta-aineista clofentetsiini ja hexythiazox poikkeavat vaikutustavaltaan meillä aikaisemmin käytössä olleista akarisideista. Molemmat valmisteet vaikuttavat ensi sijassa muna-asteisiin, sekä talvi- että kesämuniin, mutta myös vastakuoriutuneisiin toukkiin. Sen sijaan myöhempiin kehitysasteisiin vaikutus on heikko.

Laboratoriokokeissa todettiin clofentetsiinin ja hexythiazoxin tehoavan paremmin kehittymättömiin kuin pitkälle kehittyneisiin talvimuniin. Kenttäkokeissa clofentetsiinilla saatiin samansuuntaisia tuloksia: huhtikuun loppuun ajoitettu käsittely osoittautui tehokkaammaksi kuin juuri ennen kukinnan alkua toukokuussa tehty ruiskutus. Hexythiazoxin osalta tulokset kenttäkokeissa olivat osittain ristiriidassa laboratoriokokeiden antamien tulosten kanssa: myöhäinen kevätkäsittely johti parempaan tulokseen. Toisaalta hexythiazoxin kãyttö keskikesällä osoittautui kaikkein tehokkaimmaksi ja vaikutti vielä seuraavan vuoden punk- kirunsauteen. Clotentetsiinin sopiva tehoainemäärä omenapuilla on varhain keväällä $150-200 \mathrm{~g} / \mathrm{ha}$, hexythiazoxin $50 \mathrm{~g} / \mathrm{ha}$. Nestemääräksi sumuruiskulla riittää $300 \mathrm{l} / \mathrm{ha}$, kesällä suositellaan suurempaa nestemäärää paremman kattavuuden saamiseksi.

Sekä clofentetsiini että hexythiazox osoittautuivat suhteellisen haitattomiksi omenapuilla esiintyville petopunkeille. Vaikutus oli vähäinen myös äkämäpunkkeihin. Kumpikaan valmiste ei ole haitallinen hyönteispedoille tai loisille eikä pölyttäville hyönteisille, joten ne soveltuvat hyvin integroidun torjunnan yhteydessä käytettäväksi. Molempien akarisidien käytön tulisi perustua havaintoihin hedelmäpuupunkin ja petopunkkien runsaudesta, jolloin käsittelyt voidaan suorittaa todellisen tarpeen mukaan. Näin saadaan parhaiten hyödynnettyä valmisteiden selektiiviset ominaisuudet ja luodaan edellytyksiä hedelmäpuupunkin luontaisten vihollisten toiminnalle. 


\title{
EFFECT OF FOUR FUNGICIDES ON PHYTOPHAGOUS AND PREDATORY MITES ON APPLE TREES
}

\author{
TUOMO TUOVINEN
}

TUOVINEN, T. 1990. Effect of four fungicides on phytophagous and predatory mites on apple trees. Ann. Agric. Fenn. 29: 205-215. (Agric. Res. Centre, Inst. Pl. Protect., SF-31600 Jokioinen, Finland.)

In laboratory tests, $1000 \mathrm{ppm}$ dichlofluanid and $240 \mathrm{ppm}$ triforine sprayed on larvae of Panonychus ulmi either killed them or prevented their further development, but $125 \mathrm{ppm}$ bitertanol and $450 \mathrm{ppm}$ dithianon had only a slight effect on larvae. Triforine had a $75 \%$ effect on $P$. ulmi winter eggs when sprayed a few days before hatching but no effect on undeveloped eggs. Bitertanol, dichlofluanid and dithianon had no influence on winter egg hatching.

In a field experiment, four sprays in June-July with bitertanol caused a slight increase in the numbers of $P$. ulmi but did not affect Eriophyidae, Tydeidae or Phytoseiidae. Sprays with dithianon were harmless to the phytoseiid mites Paraseiulus soleiger and Amblyseius canadensis. Dichlofluanid diminished numbers and prevented egg laying of $P$. ulmi, and proved to be harmful to Eriophyidae and Phytoseiidae. Triforine diminished the numbers of Eriophyidae and Phytoseiidae, but the effect was only temporary.

The apple scab fungicides bitertanol and dithianon have been judged to be safe in integrated control programs. The use of triforine is advisable in early sprays, whereas dichlofluanid treatments should be avoided, if phytoseiid mites are present.

Index words: Panonychus ulmi, Phytoseiidae, Amblyseius canadensis, Amblyseius reductus, Paraseiulus soleiger, Eriophyidae, Tydeidae, bitertanol, dichlofluanid, dithianon, triforine, integrated control, side effect of fungicides.

\section{INTRODUCTION}

In Finland, the apple scab Venturia inaequalis (Cooke) Winter is the only commercially important disease of apple. It is currently controlled by repeated sprays of bitertanol, dichlofluanid, dithianon or triforine. In commercial orchards, fungicides are sprayed according to the length of rainy weather and prevailing temperature using the table presented by MILLS and LAPLANTE (1951), typically 4-8 times in May-July. Dithianon has been the most commonly employed fungicide for years, but recently, bitertanol and triforine have partly replaced it. Dichlofluanid has been applied in smaller amounts.

Although the destructive effects of fungicides on pest species are desirable in pest control, their similar effects on useful arthropods cause conflicts in integrated pest management programs. Laboratory and field tests surveying the side effects of pesticides have been intensively conducted by the IOBC Working Group, 'Pesticides and beneficial organisms" whose work has been recently summarized by BOLLeR et al. 
(1989). The results of these tests are useful when rating pesticides for integrated control purposes. For many pesticides, only data on the initial toxicity of the pestcides in the laboratory are available. In the case of apple scab fungicides, which might be sprayed more than 10 times a year, the results of such laboratory tests may not reveal all aspects of the side effects in the field.

Of the apple scab fungicides available in Finland, dichlofluanid and triforine have been shown to have certain side effects on tetranychid mites (KOLBE 1968, BABIKIR 1978) and on some predatory phytoseiid mites (KARG et al. 1973, STENSETH 1975). Some evidence of the possible harmful effect of bitertanol on the
European red spider mite Panonychus ulmi (Koch) (Acari: Tetranychidae) has been presented (BIGGS and HAGLEY 1988), but so far, no comparative study on the side effects of the use of the above mentioned apple scab fungicides has been performed.

The aim of this study is to compare and discuss the importance of the possible side effects of the fungicides used in Finnish apple orchards on the mite fauna in apple trees. The European red spider mite (ERM), predatory mites (Acari: Phytoseiidae), the apple rust mite Aculus schlechtendali (Nalepa) (Acari: Eriophyidae) as well as tydeid mites (Acari: Tydeidae) have been considered.

\section{MATERIAL AND METHODS}

Bitertanol was used as a $25 \%$ WP formulation (Baykor, DuPont), dichlofluanid as a $50 \%$ WP formulation (Euparen, Bayer), dithianon as a 75 $\%$ WP formulation (Delan, Shell) and triforine as a $19 \%$ WP formulation (Saprol, Shell). The reference product employed in laboratory tests against ERM, was an ovo-larvicidal acaricide hexythiazox as $10 \%$ WP formulation (Nippon Soda Co.). All sprays were performed using the recommended concentrations and doses.

\section{Effect on ERM winter eggs and larvae}

Laboratory tests were carried out on ERM winter eggs and larvae. For the test on winter eggs, they were preserved before the treatments for 10 days in a growing chamber at $+20 / 15^{\circ} \mathrm{C}$ temperature, $75 \pm 10 \% \mathrm{Rh}$ and $16 / 8 \mathrm{~h}$ photoperiod so that the first eggs would have hatched $2-3$ days after the treatments. Five to ten small twig bits, containing 25-50 winter eggs each, were placed onto filter papers in petri dishes and sprayed in a Potter tower using $2 \mathrm{ml}$ diluted fungicide per treatment. Each treatment was replicated 4 times. Control dishes sprayed with water were included. After the treatments, the twig bits were moved onto petri dishes without filter paper and each bit encircled by insect glue (Oecotak). The twig bits were checked two and four weeks after the treatments by counting the hatched larvae that stuck in the glue circle.

The tests on larvae were carried out using under one-day-old first generation ERM larvae, which were put on apple leaves, 25/leaf, using an artist's brush. The leaves were placed on wet foam rubber, face side down tightly on the rubber to prevent the larvae from hiding under the leaf. After one hour, when the larvae had started to feed, the leaves on foam rubber were sprayed in a Potter tower, and then the foam rubber pieces were put into water filled dishes so that each rubber was surrounded by water thus preventing the mites from escaping. Each treatment was replicated four times, and control leaves were sprayed with pure water. After the treatments, the dishes containing the leaves were stored in a growing chamber 
$\left(+20 / 15{ }^{\circ} \mathrm{C}, 75 \pm 10 \% \mathrm{Rh}, 16 / 8 \mathrm{~h}\right.$ photoperiod). Leaves were checked at $1-4$ day intervals and the development of the mites was followed during $11-13$ days.

\section{Field experiment}

In 1989, a field experiment was carried out in an old, neglected 0.5 ha orchard in Tammela, $100 \mathrm{~km}$ north of Helsinki. For each fungicide, one row was selected, leaving shelter rows between the sprayed ones. A spring spray with paraffin oil (Sun 7 E) for control of the apple sucker Psylla mali (Schmiedb.) (Homoptera: Psyllidae) was performed in the whole orchard before the ERM's winter egg hatching. This treatment obviously reduced also ERM numbers to some extent.

The fungicides were sprayed four times, on June 8,16 , and 22 , and July 10 , using a knapsack mist sprayer, the water amount being
$1-1.51 /$ tree. The total amounts of active ingredients per ha in the four treatments were as follows: bitertanol $1.1 \mathrm{~kg}$, dichlofluanid $11.25 \mathrm{~kg}$, dithianon $4.1 \mathrm{~kg}$ and triforine $2.1 \mathrm{~kg}$.

Assessment of the effect of sprays was made four days after the second and eleven days after the fourth spray, and in the beginning of September. For assessment, 10 leaves from five trees in each treatment were sampled and inspected under a stereomicroscope. On each leaf, mobile and egg stages of ERM, mobile phytoseiid and tydeid mites were counted, and numbers of eriophyid mites estimated. Phytoseiid mites were prepared and the species identified using the key of MiedEMA (1987) and with the help of a reference collection provided by T. Edland and the collection of KROPCZYNSKA and TuOvinen (1988). Later in the winter, five $2-3$ year-old twigs per tree from 5 trees/treatment were sampled to count ERM winter eggs.

\section{RESULTS}

\section{Effect on ERM winter eggs and larvae}

Of the fungicides tested, only triforine (240 ppm) had a significant effect on ERM winter eggs applied close to hatch (Table 1). The slight reduction in hatching caused by dichlofluanid (1 $000 \mathrm{ppm})$ and bitertanol (125 ppm) was not significant compared to untreated eggs. When sprayed on undeveloped winter eggs, triforine did not prevent them from hatching.

Triforine killed ERM larvae almost completely (Fig. 1). The few surviving larvae did not develop to nymphal stages. Dichlofluanid prevented the development of larvae although the killing effect was lower $(\mathrm{P}<0.001$, Tukey's test $)$ than that of triforine. Bitertanol and dithianon had no significant harmful effect on larvae, but the sprays caused more drowning in the surrounding water than did sprays with pure wa- ter. Both treatments caused a slight delay in nymphal development. The loss of animals in the course of the experimental period was $15-25 \%$, with the exception of bitertanol

Table 1. Effect of fungicides on ERM winter eggs in laboratory tests. A: test was carried out using long developed eggs, B: test was carried out using undeveloped eggs.

\begin{tabular}{lccc}
\hline Treatment & A.i. ppm & Hatching \% & $\begin{array}{c}\text { Effect \% } \\
\text { (Abbott) }\end{array}$ \\
\hline A. & & & \\
Bitertanol & 125 & $60.1^{\mathrm{a}}$ & 0 \\
Dichlofluanid & 1000 & $50.1^{\mathrm{a}}$ & 15.0 \\
Dithianon & 450 & $49.1^{\mathrm{a}}$ & 16.6 \\
Triforine & 240 & $14.7^{\mathrm{b}}$ & 75.1 \\
Untreated & & $58.9^{\mathrm{a}}$ & \\
\hline B. & & \\
Triforine & 240 & 85.5 & 0 \\
Untreated & & 80.1 & \\
\hline
\end{tabular}

Different letters denote significant differences (Tukey's test, $\mathrm{P}<0.05)$ in hatching \% (A). 

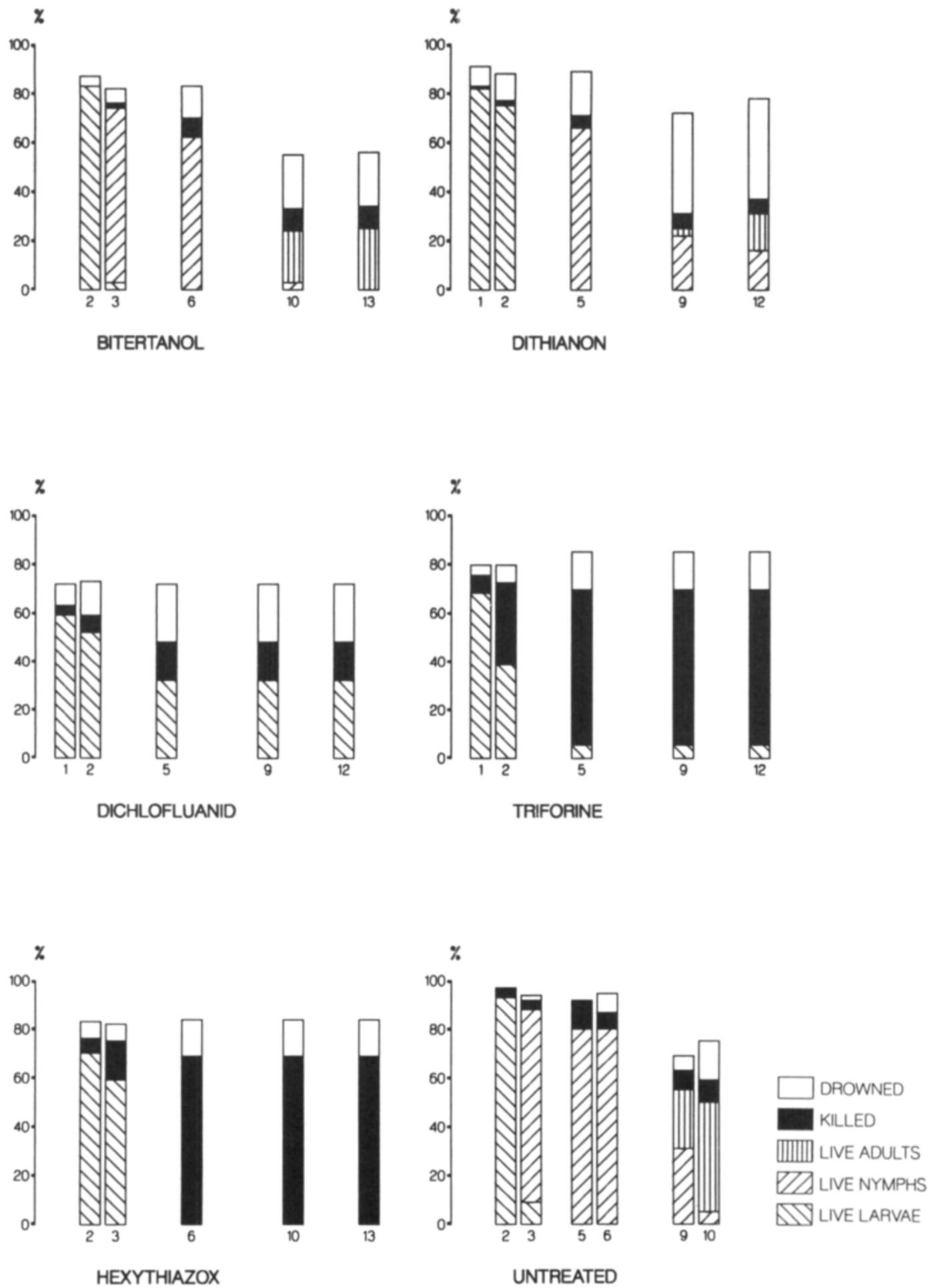

Fig. 1. Effect of fungicides on ERM larvae in the laboratory. Development of treated larvae during 10-13 days. 


\section{MOBILE P. ULMI / LEAF}

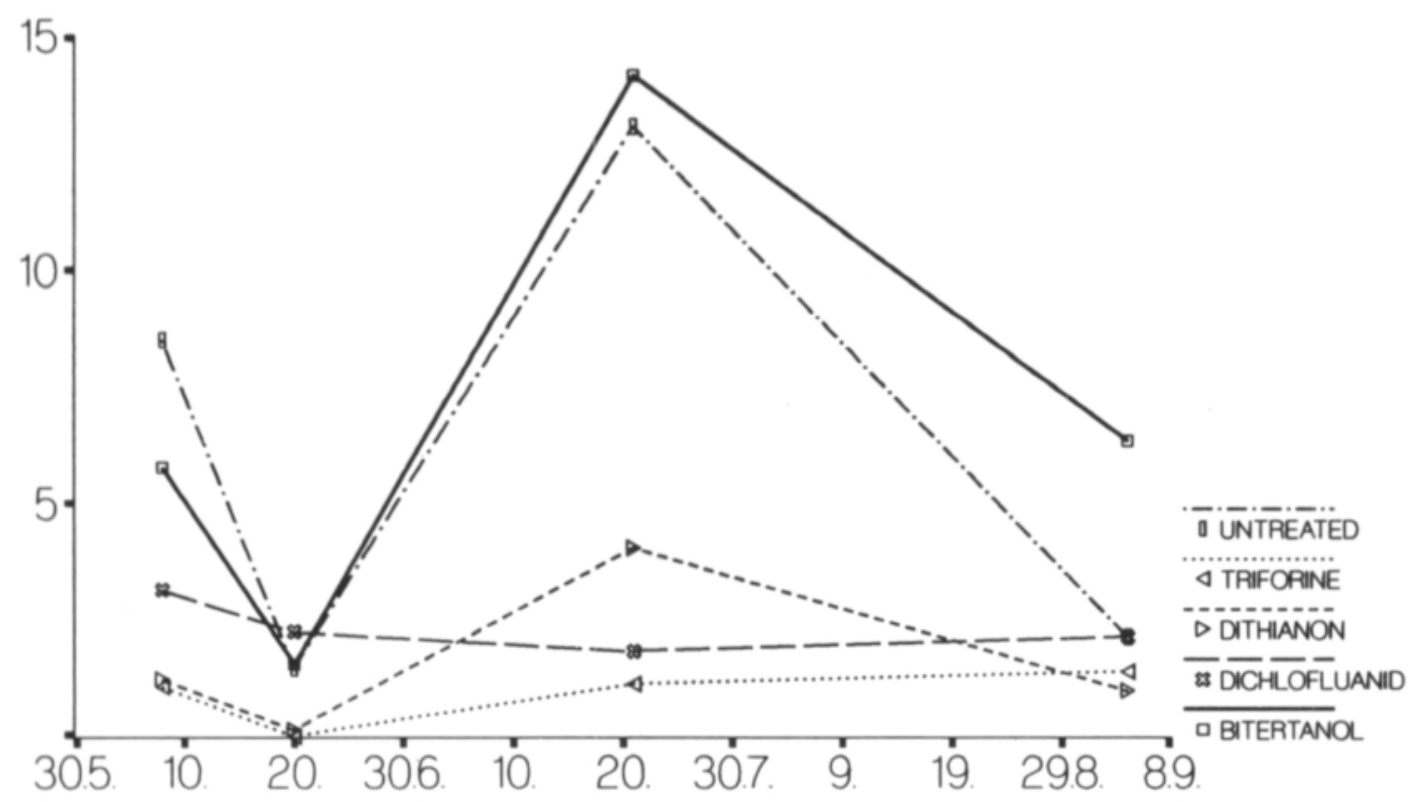

DATE

Fig. 2. Effect of four sprays with fungicides (June 8.-July 10.) on numbers of mobile ERM.

treatments, where $43 \%$ of mites disappeared from the test units.

\section{Field experiment}

Because of the differences in ERM numbers at the beginning of the experiment, the ERM data must be compared to the initial numbers before sprays to verify the population trends in each treatment (Figs. 2 and 3). Almost all of the mobile mites before the treatments were adults of the first generation (Fig. 2).

Because only four inspections were performed during the summer, the whole picture for the peak numbers in each treatment and generation cannot be presented. However, the inspection after all sprays on July 21 was timed, based on the temperature sum recordings and earlier experiences, to fit near the peak num- ber of adult mites of the second generation (Fig. 2). During the period between June 20 and July 21, the ERM population in trees treated with dichlofluanid continued to decrease, and in the trees treated with triforine, the population growth was much less than in trees treated with dithianon, having the same initial population size. Summer egg inspections revealed that the greatest reduction in egg numbers occurred in trees treated with dichlofluanid, and also triforine sprays diminished egg laying (Fig. 3).

The last inspection in September revealed that mobile ERM occurred in quite low numbers, about 2 mites/leaf, but in bitertanol treated trees the numbers were about 3 times higher than in the untreated trees (Fig. 2). Because phytoseiids were present in equal numbers in both treatments (Fig. 4), the difference cannot 
EGGS OF P. ULMI / LEAF

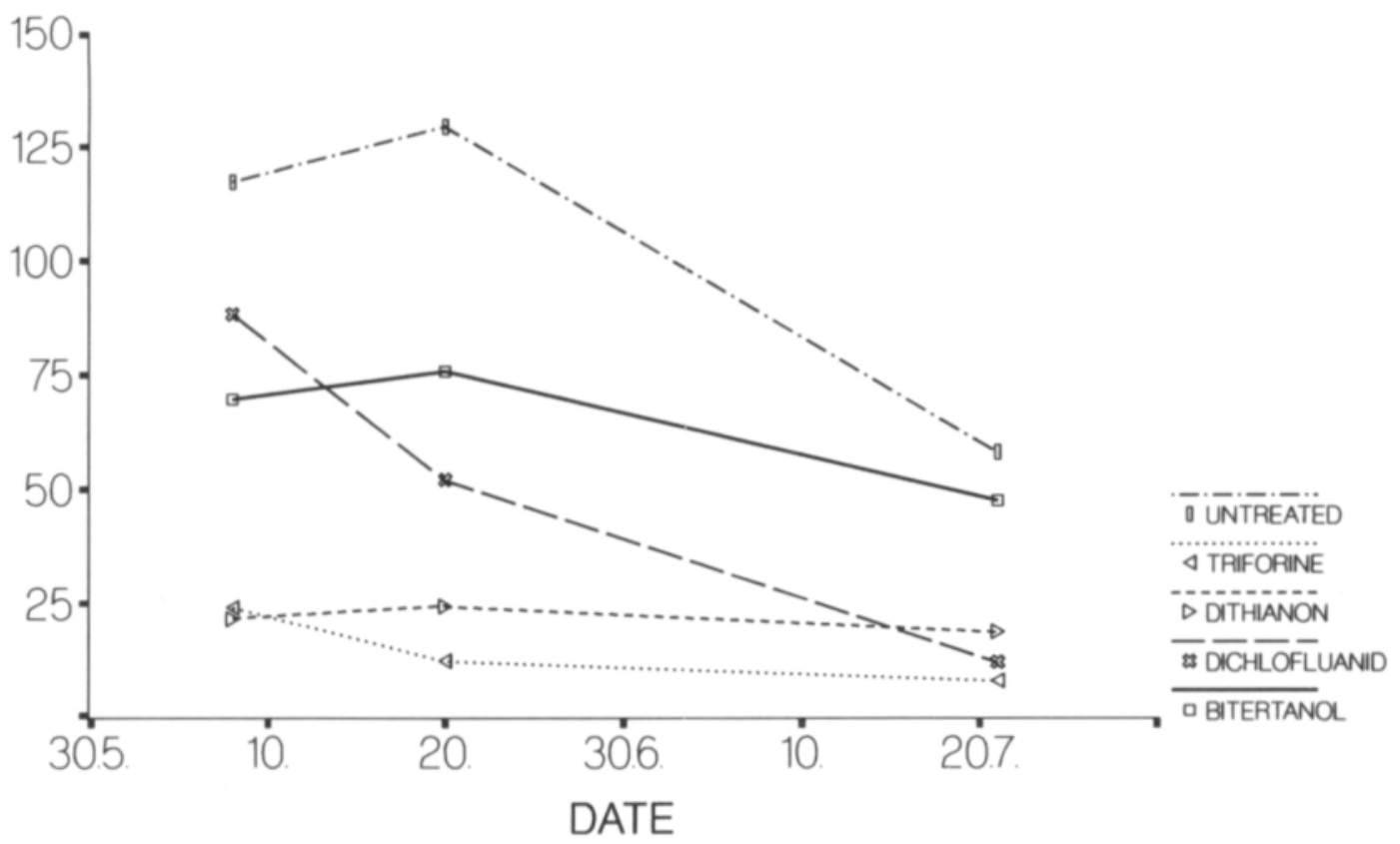

Fig. 3. Effect of four sprays with fungicides (June 8.-July 10.) on numbers of ERM eggs.

\section{MOBILE PHYTOSEIIDS / LEAF}

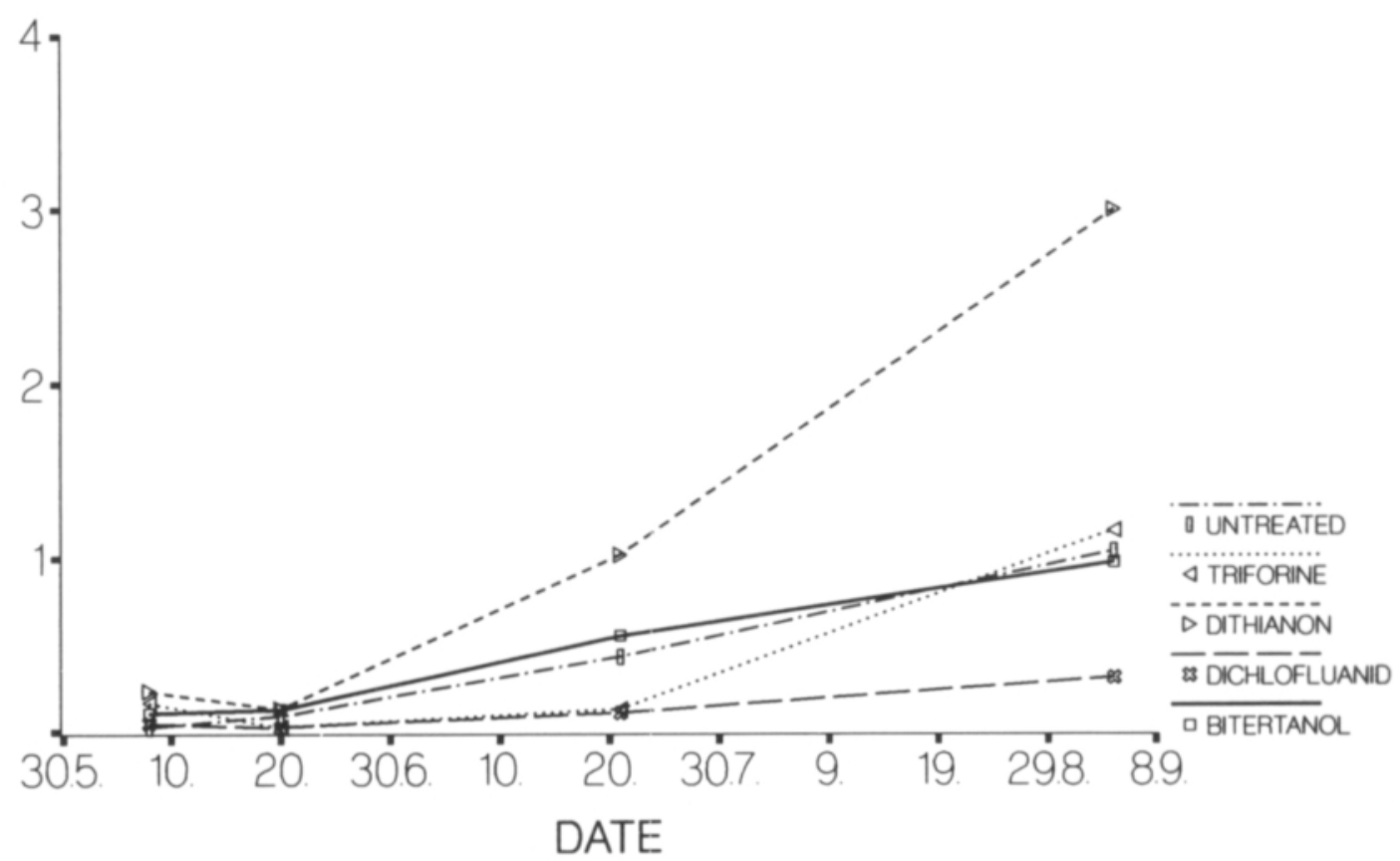

Fig. 4. Effect of four sprays with fungicides (June 8.-July 10.) on numbers of mobile phytoseiid mites. 
Table 2. Effect of four fungicidal sprays in June-July on numbers of overwintering ERM eggs. Coefficient $k$ describes the ERM population growth compared to that of untreated trees $(=1.0)$.

\begin{tabular}{|c|c|c|c|c|}
\hline \multirow[t]{3}{*}{ Treatment } & \multirow{2}{*}{\multicolumn{2}{|c|}{$\frac{\text { Before treatment }}{\text { ERM/leaf }}$}} & \multirow[t]{3}{*}{ k } & \multirow{3}{*}{ 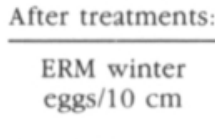 } \\
\hline & & & & \\
\hline & adults & total & & \\
\hline Bitertanol & 5.8 & 75.5 & 5.2 & 88.3 \\
\hline Dichlofluanid & 3.1 & 91.2 & 0.8 & 7.3 \\
\hline Dithianon & 1.2 & 23.1 & 3.8 & 13.3 \\
\hline Triforine & 1.1 & 25.2 & 4.4 & 14.0 \\
\hline Untreated & 8.5 & 125.7 & 1.0 & 25.0 \\
\hline
\end{tabular}

be explained by the predation caused by phytoseiids in untreated trees.

Winter egg samples during the following winter showed that in trees treated with dichlofluanid, significantly less eggs were present than in untreated trees $(\mathrm{P}<0.01$, Student's t-test $)$ or in trees treated with bitertanol $(\mathrm{P}<0.05)(\mathrm{Ta}-$ ble 2). When the initial ERM population densities are taken into account, dichlofluanid caused a reduction in ERM numbers, especially when trees treated with other fungicides are compared. Looking at the adult mite numbers in September (Fig. 2), the low numbers of winter eggs in dichlofluanid treated trees suggest that a long-term effect, diminishing ERM fecundity may have been caused by dichlofluanid. The numbers of the apple sucker $P$. mali eggs were also counted, revealing that egg numbers in untreated trees were lower than in treated trees $(\mathrm{P}<0.05)$.

The occurrence of mobile phytoseiids was scarce early in the season (eggs were not counted), increasing during the course of the summer, but present in significantly lower numbers in the trees sprayed with dichlofluanid compared to the control trees $(\mathrm{P}<0.05)$, and the trees treated with dithianon $(\mathrm{P}<0.001)$ or triforine $(\mathrm{P}<0.05)$ (Fig. 4). The approximately

\section{ERIOPHYID INDEX}

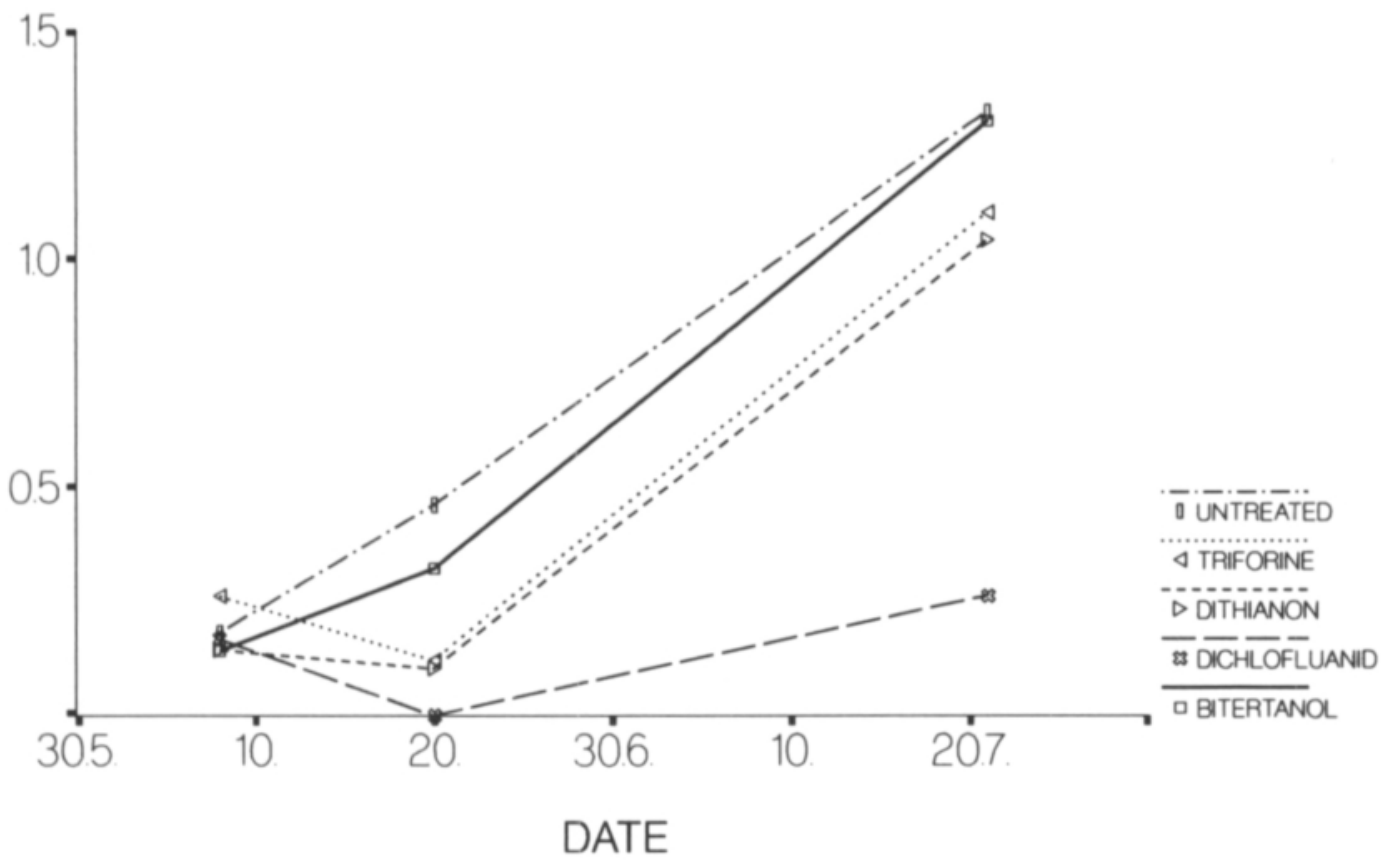

Fig. 5. Effect of four sprays with fungicides (June 8.-July 10.) on numbers of eriophyid mites 


\section{MOBILE TYDEIDS / LEAF}

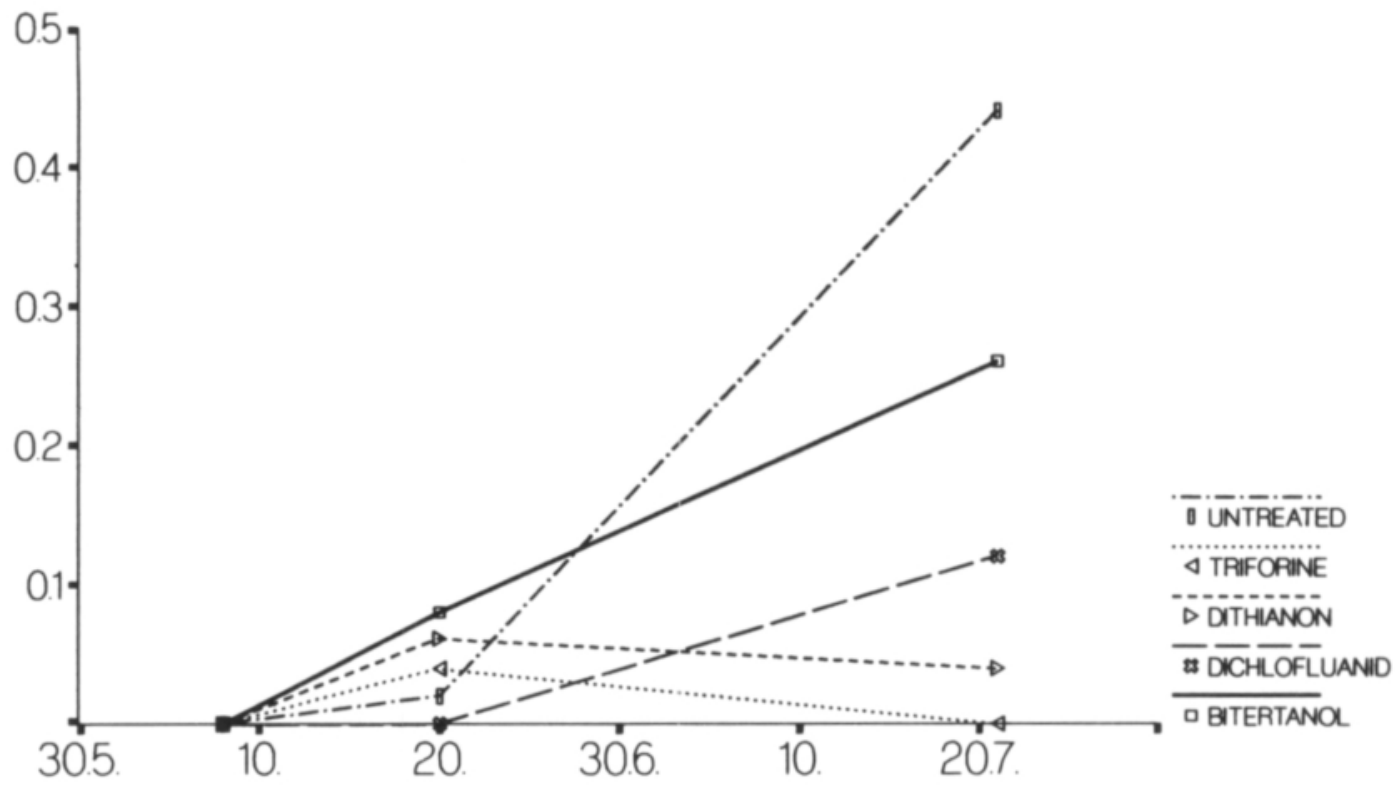

DATE

Fig. 6. Effect of four sprays with fungicides (June 8.-July 10.) on numbers of mobile tydeid mites.

three-fold number of phytoseiids in the trees treated with dithianon, compared to the other treatments $(\mathrm{P}<0.01)$ may at least partly be explained by their greater numbers before the sprays. During the spraying period, dichlofluanid and triforine hindered phytoseiid population growth, but later the population rose even faster in triforine treated trees, whereas dichlofluanid caused a more permanent reduction in phytoseiid numbers.

Paraseiulus soleiger (Ribaga) was the most common of the altogether five species of phytoseiids found in the test samples (Table 3). The other four species were Phytoseius macropilis (Banks), Euseius finlandicus (Oud.), Amblyseius reductus (Wainstein) and Amblyseius canadensis (Chant and Hansell). The specimens identified as A. cucumeris (Oud.) in the study Of KROPCZYNSKA and TUOVINEN (1988) appeared to be identical with $A$. reductus in the present study, therefore the earlier identification is considered incorrect.

Before the treatments, eriophyids occurred in almost equal numbers with the exception of

Table 3. The species composition (\%) of phytoseiid mites in trees sprayed with various fungicides. Late summer inspection in 4.9 .

\begin{tabular}{lcccccc}
\hline Treatment & Total $\mathrm{n}$ & Ph. macropilis & E. finlandicus & A. reductus & A. canadensis & $P$. soleiger \\
\hline Bitertanol & 48 & 3 & 7 & 13 & 0 & 77 \\
Dichlofluanid & 16 & 0 & 0 & 20 & 0 & 80 \\
Dithianon & 156 & 0 & 0 & 1 & 23 & 76 \\
Triforine & 59 & 0 & 3 & 0 & 17 & 73 \\
Untreated & 52 & 8 & 0 & 0 & 17 & 75 \\
\hline
\end{tabular}


triforine block (Fig. 5). The first two sprays with dichlofluanid, dithianon and triforine caused a reduction in eriophyid numbers, but later, after four sprays, only in the trees treated with dichlofluanid were the numbers significantly lower $(\mathrm{P}<0.01)$ than in other trees.
Tydeid mites, which were not identified to species, occurred only in low numbers in the experimental orchard (Fig. 6). The sprays, with the exception of bitertanol, seemed to have caused some reduction, although not significant, in the numbers of these mites.

\section{DISCUSSION}

Because of great differences in the initial numbers of ERM populations between treatments in the field experiment, only greater differences in population trends are considered to be meaningful. In case of phytoseiids as a group, the initial numbers in the experimental area were more homogenous. Comparisons between the species concerned are difficult, with the exception of $P$. soleiger, because of the diverse species spectrum in each treatment block.

Bitertanol is a relatively new fungicide (accepted for use in Finland in 1985), which has a long curative effect on apple scab, meaning that fewer treatments than with other available products may be possible. In the field experiment, bitertanol appeared to have no effect on ERM and other phytophagous mites, nor on phytoseiids, a fact which had been confirmed already in an earlier experiment (TUOVINEN 1989). Also Boller et al. (1989) have presented, based on laboratory and field tests, that bitertanol has no harmful effects on several beneficial organisms, including two phytoseiid species. BIGGS and HAGLEY (1988) concluded that $168 \mathrm{ppm}$ bitertanol sprays, repeated at 14-day intervals, might suppress ERM population. Their results, however, do not support that conclusion, because the initial ERM numbers before the treatments were lower than in other treatments, except untreated trees, and later, the numbers did not differ from those of the untreated trees.

Dichlofluanid is commonly used against grey mold in strawberries and vegetables and less against the apple scab. It has a clear effect on tetranychid mites (KOlBE 1968, KARG et al. 1973, SøRUM 1976) and this effect was shown also in the present laboratory tests. In the field experiment, dichlofluanid prevented the growth of ERM population and reduced winter egg-laying. The effect of dichlofluanid on other mite groups was harmful, and lasted the whole season in all mite groups. KARG et al. (1973) has proven that dichlofluanid sprays are harmful to the phytoseiid mite Euseius finlandicus, and Boller et al. (1989) presented that it is harmful to Typhlodromus pyri (Scheuten). In the present study, differences between phytoseiid species with respect to the effect of dichlofluanid could not be found. This fungicide is rated as harmless to anthocorid bugs (Heteroptera: Anthocoridae), which are important predators in apple orchards (BOLLER et al. 1989).

The most commonly employed fungicide against the apple scab in Finland, dithianon, appeared to have no effect on either ERM or other mites occurring on apple trees. Although laboratory tests showed that dithianon might have a sligt effect on ERM larvae, under field conditions the possible effect in question could not be verified. Dithianon showed a slightly harmful effect on eriophyid and tydeid mites. The data from the field experiment suggest that dithianon increased the numbers of the phytoseiids $P$. soleiger and $A$. canadensis. However, the nature of the mechanism of such a possible effect needs further study. Earlier studies 
have shown that the effect of dithianon is neutral when mites are concerned (FLEMMING et al. 1963, BOLLER et al. 1989).

Triforine has been reported to be effective against ERM (GILPATRICK et al. 1972), and slightly harmful to mobile stages of the phytoseiid mite Phytoseiulus persimilis Athias-Henriot (STENSETH 1975). However, van ZON and WYSOKI (1978) reported that 100-400 ppm triforine did not cause any mortality in females of the phytoseiid $P$. persimilis, nor in eggs or juveniles. In the present study, triforine was the only fungicide, which prevented ERM winter egg hatching, and in laboratory tests this fungicide was the most effective against ERM larvae. The results of the field test seem to support these results, although the low initial population level makes the comparison difficult. The population growth of phytoseiids was at first hindered by triforine, but after the sprays, the numbers of mobile phytoseiids grew faster compared to dichlofluanid. This observation suggests that triforine is not as harmful as dichlofluanid to all stages of phytoseiid mites, in this case $P$. soleiger and A. reductus. BOLLER et al. (1989) also presented that triforine is not harmful to $P$. persimilis or $T$. pyri. Eriophyid mites seem to recover from triforine treatments after the sprays have been discontinued.

In the field experiment, the overwintering ERM population in untreated trees appeared to be lower than could be expected on the basis of the size of the summer generation. As in this study no other predators than phytoseiid mites were collected, the effect of other factors could not be evaluated. At least anthocoriid bugs occurred as common predators in the orchard, but no comparative data are available to look at possible differences in their numbers between treatments.

\section{CONCLUSIONS}

Because of the observed differences in the fungicides used against apple scab concerning the side effects on ERM and phytoseiid mites, it is important to choose a fungicide also bearing in mind mite management in the apple orchard.

Only slight or no side effects were found in the case of bitertanol and dithianon, and these products are thought to be neutral as far as mite management is concerned.

Dichlofluanid should not be used for apple scab control, if the phytoseiids are to be conserved. On the other hand, dichlofluanid reduces ERM numbers so effectively that any special mite control might be unnecessary. Being harmless to predatory anthocorid bugs, this product might have restricted temporary use in integrated mite management, in situations when no phytoseiids are present.

Triforine affects all mite groups, but not as strongly as dichlofluanid. This fungicide, which also reduces ERM winter egg hatching, can be used in early spring sprays against apple scab. Phytoseiids, at least $P$. soleiger and $A$. reductus, seem to have some tolerance towards triforine, however, one should avoid frequent use of this fungicide.

\section{REFERENCES}

BABIKIR, E.T.A. 1978. Factors affecting biological control of the red spider mite in glasshouses. The effect of fungicides and light intensity on the population dynamics of Tetranychus urticae and its predator Phytoseiulus per- similis with reference to the efficiency of biological control in glasshouses. Thesis, Bradford University, U.K. $178 \mathrm{p}$.

BigGs, A.R. \& HAGLEY, E.A.C. 1988. Effects of two sterolin- 
hibiting fungicides on populations of pest and beneficial arthropods on apple. Agric. Ecosystems Environ. 20: 235-244.

Boller, E., Bigler, F., Bierı, M., Hänı, F. \& Stäubli, A. 1989. Nebenwirkungen von Pestiziden auf die Nützlingsfauna wirtschaftlichen Kulturen. Schweiz. Landw. Fo. 28: 3-40.

Flemming, H., Hierholzer, O. \& Mohr, G. 1963. Dithianon - eine organische Verbindung mit breiter fungizider Wirkung. Z. Pflanzenkrankh. 70: 4-11.

Gilpatrick, J.D., Fridrich, T., Smith, A.A. \& Lienk, S.A. 1972. Orchard control of diseases and mites in apple with a new piperazine derivative fungicides. Plant Dis. Rep. 56: 451-455.

KARG, W., Burth, U. \& Ramson, A. 1973. Der Einfluss von Fungiziden auf das Auftreten von Spinnmilben und anderen blattbewohnenden Milbengruppen in Apfelanlagen. Nachr.bl. Pfl.schutzd. DDR 27: 169-175.

KolBE, W. 1968. Wirkung verschiedener Spritzfolgen zur gleichzeitigen Bekämpfung von Schorf, Mehltau und Spinnmilben sowie deren Einfluss auf Ertrag und Fruchtqualität im Kernobstbau. Pfl.schutz-Nachr. Bayer 21: $171-221$

KropCZYNSKA, D. \& TUOVINEN, T. 1988. Occurrence of phytoseiid mites (Acari: Phytoseiidae) on apple trees in Finland. Ann. Agric. Fenn. 27: 305-314.

MiedemA, E. 1987. Survey of Phytoseiid mites (Acari:
Phytoseiidae) in orchards and surrounding vegetation of north-western Europe, especially in the Netherlands. Keys, descriptions and figures. Neth. J. Pl. Path. Suppl. No 2: 1-64.

Mil.s, W.D. \& LAPLANTE, A.A. 1951. Diseases and insects in the orchard. Cornell Ext. Bull. 711: 21-27.

STENSETH, C. 1975. Virkningen av noen sopp- og skadedyrmidler på rovmidden Phytoseiulus persimilis AthiasHenriot (Acarina: Phytoseiidae). Forskn. Fors. Landbr. 26: $393-404$.

SøruM, O. 1976. Kjemiske midler mot frukttremidd (Panonychus ulmi Koch) i integrert bekjempelse på eple. I: Soppmidler. Forskn. Fors. Landbr. 27: 745-764.

TUOVINEN, T. 1990. Chemical control of European red spider mite Panonychus ulmi (Koch). II. Evaluation of clofentezine and hexythiazox. Ann. Agric. Fenn. 29: 195-204

ZoN, A.Q. van \& WYsOKı, M. 1978. The effect of some fungicides on Phytoseiulus persimilis (Acarina: Phytoseiidae). Entomophaga 23: 371-378.

\section{Manuscript received January 1990}

Tuomo Tuovinen

Agricultural Research Centre

Institute of Plant Protection

SF-31600 Jokioinen, Finland

\section{SELOSTUS}

\section{Omenaruven torjunta-aineiden vaikutus omenapuulla esiintyviin punkkeihin}

\section{TUOMO TUOVINEN}

Maatalouden tutkimuskeskus

Suurin osa omenapuun kasvinsuojeluruiskutuksista on omenaruven torjuntaa. Suomessa tähän käytetään ditianoni(Delan), bitertanoli- (Baykor), triforiini- (Saprol) ja diklofluanidi-valmisteita (Euparen). Toistuvilla ruiskutuksilla on vaikutuksia myös hyönteisiin ja punkkeihin. Tässà tutkimuksessa on selvitetty valmisteiden vaikutusta ensisijaisesti hedelmäpuupunkkiin ja petopunkkeihin.

Laboratoriokokeissa todettiin triforiinin heikentävän hedelmäpuupunkin talvimunien kuoriutumista, mikäli munat olivat saaneet kehittyä lähelle kuoriutumisajankohtaa. Muilla valmisteilla ei ollut vaikutusta talvimuniin. Triforiini ja diklofluanidi aiheuttivat hedelmäpuupunkin toukkien huomattavaa kuolleisuutta ja lisäksi estivät niiden yksilönkehitystä. Muiden valmisteiden vaikutus toukkiin oli vähäinen.

Kenttäkokeessa, jossa valmisteita ruiskutettiin neljä kertaa kesä-heinäkuussa, diklofluanidi häiritsi kaikkien punkkiryhmien lisääntymistä. Myōs triforiini ehkäisi jossain määrin hedelmäpuupunkkien runsastumista, ja vaikutti aluksi haitallisesti myös petopunkkeihin ja äkämäpunkkeihin. Tämä vaikutus oli kuitenkin lyhytaikainen ja petopunkkikanta toipui nopeasti ruiskutuksista. Bitertanolilla ja ditianonilla ei ollut haitallista vaikutusta mihinkään punkkiryhmään, sen sijaan ditianonilla ruiskutetuissa puissa oli selvästi enemmän petopunkkeja kuin muissa puissa.

Käytännön johtopäätökset intgroidun torjunnan kannalta ovat seuraavat: 1. Bitertanolin ja ditianonin käyttö ei vaikuta haitallisesti punkkien luontaiseen torjuntaan petopunkkien avulla, mutta ei myöskään suoraan văhennă hedelmãpuupunkkien määrää. 2. Triforiinin käyttö keväällä ensimmäisissä ruiskutuksissa voi helpottaa hedelmäpuupunkin torjuntaa, aiheuttamatta kuitenkaan suurta vahinkoa petopunkeille. 3. Diklofluanidi vaikuttaa hedelmäpuupunkkia torjuvasti, mutta on haitallinen myös petopunkeille. Tilapäistä kãyttöä voi harkita, jos petopunkkeja ei esiinny omenatarhassa. 